\title{
Linking Rural Livelihood and Conservation in Hoang Lien National Park, Lao Cai Province, Vietnam
}

\author{
by \\ Ha Nguyen Thi Thuy \\ A thesis submitted in partial fulfillment of the requirements for the \\ degree of Master of Science in \\ Natural Resources Management
}

Examination Committee: Dr. Damien Jourdain (Chairperson) Prof. Ganesh Prasad Shivakoti Dr. Clemens Grunbuhel

\author{
Nationality: Vietnamese \\ Previous Degree: $\quad$ Bachelor of Science in Crop Science \\ Hanoi University of Agriculture, Vietnam \\ Scholarship Donor: Deutscher Akademischer Austausch Dienst \\ (DAAD), Germany - AIT Fellowship
}

Asian Institute of Technology

School of Environment, Resources and Development

Thailand

May 2014 


\section{Acknowledgments}

The completion of this Master thesis involves several people, who in their own special way, shared their time, efforts and knowledge for the success of this undertaking.

I would like to express my deep appreciation to my Thesis advisor, Dr. Damien Jourdain and my Academic advisor, Dr. Clemens Grunbuhel for their kind interest, encouragement and guidance in my study. I also would like to express my gratitude to Prof. Ganesh Prasad Shivakoti, member of the thesis examination committee for his valuable advices, comments and constructive suggestions. I cannot describe how much I learned from them during our numerous discussions. Their supervisions took me through many difficulties from writing the proposal till the completion of my thesis.

Grateful acknowledgment is also given to the staff of the SERD office and NRM field of study for their pleasant assistance and graciously responding to all my requests. I also would like to express my grateful to Dr. Dao The Anh, Mr. Nguyen Van Son, Mr. Bui Quang Duan and Ms. Tran Thi Huyen in Centre for Agrarian Systems Research and Development (CASRAD) in Hanoi, Vietnam and Management Board of Hoang Lien national park in Sapa district, Lao Cai province, Vietnam along with officers of People committee at different levels for their support and warm encouragement throughout the conduct of the study. I also would like to express my gratitude to village heads and villagers in six selected villages in both core zone and buffer zone in HLNP for their kind help during my stay in each village, especially households sampled and key informants which provided me valuable time and information needed for my study.

I wish to express my full appreciation to my scholarship donors, The Deutscher Akademischer Austausch Dienst (DAAD) and AIT Fellowship for giving me opportunity to study the Master program of Natural Resources Management in Asian Institute of Technology and conduct the research.

Explicitly, I wish to address my sincere thanks to my family and friends for their love, understanding and various ways of help. 


\begin{abstract}
Creation of protected areas for biological conservation often conflicts with sustenance of livelihood of local people living inside or nearby regions. Combination between biological conservation and livelihood development has been much remained to be done in protected areas in developing countries. Hoang Lien national park in Northern Vietnam has become an intensive commercial forest farming area of black cardamom (Amomum aromaticum) recently. As a mean of updating information base for long term management, a study was carried out to explore livelihood strategies, evaluate the importance of cardamom in local people's livelihood and identify potential alternative cash-income generating activities in the region. Household survey, key informant interviews and focus group discussion were conducted in both core zone and buffer zone of the national park. Results indicate that most of local people in both zones depend on sedentary agriculture and forest resource extraction for subsistence. Core zone community is more dependent on cardamom cultivation than buffer zone community. Principal Component Analysis and Cluster Analysis was conducted to identify different types of households which plant cardamom. Seven groups of households were formed based on different characteristics in household size, labor, distance to market, land endowment, livestock system, yearly cash income of households and capita and income diversification. To six groups, cardamom is the most important cash income source with its contribution in total net cash income in range from $39 \%$ to $98 \%$. One group remaining is highly dependent on tourism-based livelihood activity with $67.4 \%$ share of tourism in total net cash income. If cardamom cultivation is banned in the HLNP by the state power, households belong to Group 4, 5 and 6 which are highly depend on cardamom and Group 2 which is poor and moderately dependent on cardamom will be the most affected. It is impossible to ban cardamom cultivation in the HLNP because it will create shocks and increase poverty. Reducing dependence of rural livelihood on cardamom cultivation through income diversification is required. Several potential cash income generating activities in the region and adjacent areas were identified in which raising livestock and planting vegetables are familiar with local people. Other unfamiliar activities such as planting Atiso (Cynara scolymus Lour) and raising dove will be difficult to adopt. Tourism based activities such as home-stay and selling handicraft has developed in the buffer zone and reduced dependence of local people on forest, however, it is negatively affected due to tragedy of the commons.
\end{abstract}

Key words: Hoang Lien national park, conservation, livelihood, cardamom, subsistence, cash income, cash income generating activities, tourism 


\section{Table of Contents}

Chapter Title Page

Title page $\quad$ i

Acknowledgements $\quad$ ii

Abstract iii

Table of Contents

List of Tables vi vii

List of Figures $\quad$ viii

List of Abbreviations $\quad$ ix

$1 \quad$ Introduction 1

1.1 Background 1

1.2 Statement of the problem 3

1.3 Objectives, research questions and hypothesis 6

$\begin{array}{ll}1.4 \text { Scope and limitations } & 7\end{array}$

$2 \quad$ Literature Review $\quad 8$

2.1 Protected areas in Vietnam $r$

2.2 Background of livelihood 11

2.3 Application of sustainable livelihood framework in Vietnam 13

2.4 Linking livelihood and conservation in protected areas 16

2.5 Linking biodiversity conservation, livelihood and tourism 22

2.6 Effects of cardamom cultivation on forest ecosystem 23

$3 \quad$ Methodology 25

3.1 Selection of the study area $\quad 25$

3.2 Overview of research design 25

3.3 Data collection 25

$\begin{array}{ll}3.4 & \text { Data processing and data analysis }\end{array}$

$4 \quad$ Study area 30

4.1 Location of the HLNP 30

$\begin{array}{ll}4.2 \text { History of establishment and development } & 31\end{array}$

4.3 Topography, hydrology and climatic condition 31

$\begin{array}{ll}4.4 \text { Biodiversity values } & 32\end{array}$

4.5 Social-economic condition 33

4.6 Communes and villages selected 35

$\begin{array}{lll}4.7 & \text { Upland landscapes (transect) } & 37\end{array}$

$5 \quad$ Respondents and household characteristics $\quad 40$

5.1 Characteristics of respondents 40

5.2 Household characteristics 44

$6 \quad$ Agricultural production in the HLNP 50

6.1 Current crops, variety and purpose for cultivation 50

$\begin{array}{lll}6.2 & \text { Farming calendar } & 51\end{array}$

6.3 Cropping system $\quad 53$

$\begin{array}{lll}6.4 & \text { Livestock system } & 59\end{array}$ 
$\begin{array}{lll}6.5 \text { Aquaculture } & 61\end{array}$

$7 \quad$ Conclusion and Recommendations

7.1 Frequency of local people go to forest 62

$\begin{array}{ll}7.2 \text { Firewood collection } & 63\end{array}$

$\begin{array}{lll}7.3 & \text { Timber extraction } & 63\end{array}$

7.4 NTFPs extraction $\quad 64$

$\begin{array}{ll}7.5 & \text { Hunting and catching animals } \\ 7.6 & 66\end{array}$

$\begin{array}{lll}7.6 & \text { Forest farming } & 67\end{array}$

7.7 Participation of local people in forest protection 71

$8 \quad$ Contribution of cardamom to livelihood of local people $\quad \mathbf{7 2}$

8.1 Income diversification of local people in the HLNP differentiated 72 by zone

$\begin{array}{ll}8.2 \text { Household typology } & 74\end{array}$

8.3 Economic loss when cardamom cultivation is banned in HLNP 81

$9 \quad$ Potential livelihood activities of local people in the HLNP 83

9.1 Potentiality of current agricultural products in the HLNP 83

9.2 Potentiality of tourism-based livelihood activities in the HLNP 87

9.3 Potentiality of other products in the region 92

9.4 Summary of potential cash-income generating activities in the 95 HLNP and adjacent areas

9.5 Income diversification or replacement of cardamom cultivation 98 by other livelihood activities?

10 Discussion, Conclusion and Recommendation 100

$\begin{array}{ll}10.1 \text { Discussion } & 100\end{array}$

10.2 Conclusion 108

10.3 Recommendation for livelihood improvement and conservation 110

10.4 Recommendation for further studies

$\begin{array}{ll}\text { References } & 113\end{array}$

$\begin{array}{lr}\text { Appendices } & 122\end{array}$ 


\section{List of Tables}

Table Title

Page

2.1 The system of protected area in Vietnam and their equivalent IUCN

category

2.2 Size of protected area in Vietnam by categories and total special-use

forest

$2.3 \quad$ Vietnam protected areas which is not under IUCN categories 10

$2.4 \quad$ Five categories of livelihood assets 11

Types of forest dependency in Vietnam

Some approaches in linking conservation and development in practice

Vertebrates species in the HLNP

Current status of the ethnicity, population and labor of communes in the HLNP

Locations of 6 selected villages in part of HLNP belonging to Lao Cai province.

$5.1 \quad$ Demographic characteristics of households sample $\quad 40$ cardamom cultivated area)

5.10 Total land use area of households sampled (including cardamom 46 cultivated area)

$5.11 \quad$ Housing condition of households sampled in four selected villages $\quad 47$

$5.12 \quad$ Main assets of households sampled in four selected villages 48

5.13 Distribution of households sampled by total net cash income 49

6.1 Farming calendar of local people living in the HLNP 52

6.2 Land use area per capital in core zone and buffer zone of the HLNP 53

6.3 Rice security status of households sampled in the HLNP 54

6.4 Area of maize cultivated area of local people in the HLNP 57

6.5 Area of home garden of local people in the HLNP 58

6.6 Distribution of household sampled by livestock 59

6.7 Average number of livestock in the HLNP 60

6.8 Fishpond in the HLNP 61

7.1 Frequency of going to forest of local people off cardamom season in 62

7.2 Energy use for cooking and heating of household sampled 63

7.3 NTFPs extraction in the HLNP in 2012.

7.4 Production of cardamom in three selected communes 67

$\begin{array}{lll}7.5 & \text { Cardamom cultivation in the HLNP } & 68\end{array}$

7.6 Compare economic efficiency of cardamom production and rice 69

8.1 Cash income sources of local people in HLNP differentiated by zone $\quad 72$ 
8.2 Rank of importance of income source of local people in two zones of 73 the HLNP

8.3 Descriptions and summary statistics of variables using in PCA 75

8.4 Six components resulting from PCA with loadings for twenty original 76 variables (only loadings higher than 0.4 were shown)

8.5 Farm household's main characteristics 79

8.6 Economic loss if cardamom cultivation is totally banned in the HLNP 82 by state power

9.1 SWOT analysis of annual crops in the HLNP 83

9.2 SWOT analysis of livestock in the HLNP 85

9.3 Number of visitors come to Sapa district recently 87

9.4 SWOT analysis of homestay service in Ta Van Giay 1 village in the 88 buffer zone

9.5 Models introduced by HLNP Management board and Local 92 government in 2013

9.6 SWOT analysis of Atiso (Cynara Scolynus Lour) in Sapa district 93

$9.7 \quad$ SWOT analysis of raising dove 94

9.8 SWOT analysis for raising goat in Seo My Ty village of the HLNP 95

9.9 Summary of potential livelihood activities in the HLNP 96

9.10 Choosing of respondents about alternative livelihood activities in case 97 cardamom cultivation is banned in the HLNP 


\section{List of Figures}

$\begin{array}{lll}\text { Figure Title } & \text { Page }\end{array}$

2.1 Framework of sustainable livelihood analysis 12

2.2 The cycle of disadvantages for ethnic minorities 14

2.3 Agriculture and social-economic transformation in Ngoc Phai 15

2.4 Scenario of no linkage between livelihood and conservation and its $\quad 18$

2.5 Scenario of indirect linkage between livelihood and conservation and 19 its frame work called economic substitute

2.6 Scenario of direct linkage between livelihood and conservation and its 20

2.7 Conservation requires a combination of different strategies 21

$2.8 \quad$ Linkages among biodiversity conservation, livelihood improvement 23 and tourism development

$3.1 \quad$ Analysis process of qualitative data 28

4.1 Location of the Hoang Lien national park 30

4.2 Six villages selected of which four villages selected for hh survey 36

4.3 Upland transect and different agro-ecological zones in the HLNP 37

$4.4 \quad$ Agro-ecological zone in the HLNP. 38

$5.1 \quad$ Distribution of respondents by gender 40

$5.2 \quad$ Distribution of respondents by education 42

5.3 Distribution of respondents by ethnicity 42

6.1 Number of households sampled grow and sell main types of crops 50

6.2 Use of variety in cultivation or rice and maize in the HLNP 51

6.3 Precipitation and temperature of Sapa district, Lao Cai province, 51

6.4 Effects of the Seo Trung Ho hydro-power project on land use in Seo 55

8.1 Dendogram resulting from Ward's method of cluster analysis $\quad 78$

8.2 Cash income structure of typological households groups 82 


\section{List of Abbreviations}

$\begin{array}{ll}\text { AIT } & \text { Asian Institute of Technology } \\ \text { BCN } & \text { Biodiversity Conservation Network } \\ \text { CBET } & \text { Community-based ecotourism } \\ \text { CBM } & \text { Community-based management } \\ \text { DFID } & \text { Department for International Development } \\ \text { FPD } & \text { Forest Protection Department } \\ \text { FSIV } & \text { Forest Science Institute of Vietnam } \\ \text { HLNP } & \text { Hoang Lien National Park } \\ \text { ICEM } & \text { International Centre for Environmental Management } \\ \text { IUCN } & \text { International Union for the Conservation of Nature } \\ \text { WWF } & \text { World Wildlife Fund } \\ \text { MEA } & \text { The Millennium Ecosystem Assessment } \\ \text { MONRE } & \text { Ministry of Natural Resources and Environment } \\ \text { NTFPs } & \text { Non-timber forest products } \\ \text { RAMSAR } & \text { The Convention on Wetlands of International Importance } \\ \text { SCBD } & \text { Secretariat of the Convention on Biological Diversity } \\ \text { SFEs } & \text { State Forest Enterprises } \\ \text { SLA } & \text { Sustainable Livelihood Approach } \\ \text { SPSS } & \text { Statistical program for Social Science } \\ \text { UN } & \text { United Nation } \\ \text { UNEP-WCMC } & \text { United Nations Environment Programme - World Conservation } \\ & \text { Monitoring Centre } \\ \text { UNFPA } & \text { United Nations Population Fund } \\ \text { USD } & \text { United State Dollar } \\ \text { TIES } & \text { The International Eco-tourism Society } \\ \text { VEM } & \text { Vietnam Environmental Monitor } \\ \text { VPEA } & \text { The Vietnam Environment Protection Agency } \\ & \end{array}$




\section{Chapter 1}

\section{Introduction}

\subsection{Background}

Forest provides human with both "direct use" and "indirect non-use" benefits (Tumusiime et al., 2011: 273). Similar to other natural resources, in addition to irreplaceable provisioning ecosystem service such as food, shelter, medicines..., forest ecosystem and biodiversity support human with supporting services (i.e nutrient cycling, soil formation, primary production), regulating services (i.e climate regulation, water purification, disease reduction) and cultural services (i.e aesthetic, spiritual, educational, recreational services) (The Millennium Ecosystem Assessment (MEA), 2005). However, human society always undervalue those important services despite a fact that a number of low and middle-income economies are highly dependent on exploitation natural resources (Barbier, 2005) and export them as raw materials. It is estimated that $70 \%$ of the world's poor live in rural areas and depend on biodiversity for the most basic needs in their lives (Secretariat of the Convention on Biological Diversity (SCBD), 2009). It is common that local people in remote areas significantly depend on forest resources for their livelihoods (Youn, 2009).

Forest loss and biodiversity degradation is the result of both proximate and underlying causes (Dietza and Adgerb, 2003). Proximate causes include infrastructure extension, agricultural expansion, wood extraction and non-timber forest products (NTFPs) collection (Geist and Lambin, 2002) which lead to main causes of biodiversity loss including habitat loss and habitat fragmentation, over-exploitation of timber and NTFPs by both government policy, local community and illegal groups, introduction of exotic species, homogenization in agriculture and forestry, environmental change, "knock-on" effects (species that are coevolved with another will go extinct if one of the pair goes extinct) (Hens and Boon, n.d.). Underlying driving forces of forest and biodiversity loss are anthropogenic drivers and can be identified as demographic factors, economic factors, policy and institutional factors, cultural factors and technological factors (Stedman-Edwards, 1998; Geist and Lambin, 2002) In details, they refer to pressure from population growth, migration, market growth, urbanization and industrialization, lack of suitable policy and enforcement and weakness in biodiversity management and individual behavior... All these problems slow down biodiversity conservation and indirectly cause degradation of biological resources left in ecosystems.

To protect natural ecosystem especially forest and biodiversity resources, protected areas have been created in all nations as the most essential strategy to decrease speed of habitat loss and/or degradation and mitigate species reduction rate (Mbile et al., 2005). It is defined as "an area of land and/or sea especially dedicated to the protection and maintenance of biological diversity, and of natural and associated cultural resources, and managed through legal or other effective means" (The International Union for the Conversation of Nature (IUCN), 1994). Protected areas covered $12.7 \%$ of the world's terrestrial (including inland water) and 10\% of coastal and marine area in 2010 and it is targeted to increase to at least $17 \%$ of terrestrial areas and $10 \%$ of coastal and marine areas in next decade (United Nations Environment Programme World Conservation Monitoring Centre (UNEP-WCMC), 2012). Between 1990 and 2010, protected areas have increased by $58 \%$ in number and $48 \%$ in their extent (United Nation (UN), 2012).

Efforts of the world community in building and strengthening the protected areas system as 
a strategy to conserve biological resource cannot be denied. However, protected areas impact livelihood of local people who depend on forest resources for survival and wellbeing, especially poor communities living inside or nearby borders (Mbile et al., 2005) because most protected areas in developing countries were established in remote areas inhabited by poor populations (Sanderson, 2005 cited by Nyaupane and Poudel, 2011). It is estimated that about 60 million indigenous people are almost wholly dependent on forests and 350 million people depend on forests for a high degree for subsistence and income (World Bank, 2004). Once the protected area established, for the purpose of biodiversity conservation, local people are forced to leave where they traditionally engaged and move to other areas follow resettlement programs of the government (Cernea and Schmidt-Soltau, 2003). They are often restricted from the access to natural resources inside the boundary and from carrying out their forest-based livelihood activities such as collections of firewood, medical plants, hunting animals... (Ghimire, 1994). Moreover, community often faces losses of crop and livestock due to animals in protected areas (Lewis, 1996). Despite significant impacts on their lives, local community often has no formal voice in protected area management (International Centre for Environmental Management (ICEM), 2003). Distribution of benefits are also uneven among stakeholders represented by the fact that the greatest benefit shared by national or world community is at the cost of local community inhabiting in and around conserved area (Lewis, 1996).

Therefore, the relationship between forest-society or resources-resource users in protected areas has become the complex issue primarily due to conflict between livelihood sustenance of local people and the biological conservation objective of the government (Salafsky and Wollenberg, 2000). It is the government's ignorance to basic needs of local people in protected area and uneven distribution of benefits among involved actors limit the participation of community in conservation activities (Ghimire, 1994). How to redress the imbalance and improve support of local people for conservation becomes the primary challenge facing all protected areas at present (Twyman, 2001). It requires having deep understanding about relationship between conservation and livelihood as well as poverty because conservation limits forest-based livelihood activities leading to poverty whereas poverty significantly limits success of conservation if conservation is not effective in addressing poverty issues (Adam et al., 2004). Diversifying livelihood "by engaging in new income opportunities, by taking advantage of a range of different crops to increase food security, or by attempting to undertake a mixture of agricultural, livestock, and offfarm activities" (Turner, 2007: 403) not only help local resident cope with shocks and stresses but also reduce forest access and forest resources extraction to community living in or near by remote forest.

With the increase of the world population including local communities living inside or nearby boundaries of protected areas, to meet the basic need, expansion of agriculture as well as other economic activity is inevitable. One again, forest is cleared for crop cultivation, livestock grazing, and infrastructure construction... Conflict between preservation and use or conservation and livelihood always exists because "protected area have been, are, and will continue to be used by people, irrespective of what park management agencies say and do" (Sheppard, 1987: 23 cited in Wearing and Neil, 2009). Among industry, tourism is considered as a key because it supplies economic rationale for protection and conservation of natural areas rather than developing agriculture and industry in these areas (Wearing and Neil, 2009). Tourism "can help the sustainable management of protected areas, as a market-based alternative catering to the growing number of discriminating travelers trying to find, understand and enjoy natural environment" (Eagles et al., 2002). It is clearly represented in definition of ecotourism as "responsible travel to 
natural areas that conserves the environment and improves the well-being of local people" and ecotourism principles including "uniting conservation, communities, and sustainable travel" (The International Ecotourism Society (TIES), 1990). Eco-tourism not only helps reduce impacts on environment but also provides direct financial benefit for conservation (Honey, 2008) through using profit from entrance fees and other fees to pay for protection and management of national parks (Sunlu, 2003). It may create important livelihood activities and conservation incentive for local people living inside or nearby protected areas (Bennett et al., 2012) and increase awareness of local community and visitors on environment and natural resources (Eagles et al., 2002). Protected area and tourism has been linked throughout the history of protected area (Eagles et al., 2002). At present, community-based ecotourism (CBET) has become a popular tool in biodiversity conservation although it requires considerable investment of support and time to reach its objectives as creating income for local community with minimized impacts on environment (Kiss, 2004).

\subsection{The problem statement}

Biological diversity conservation is one of the most important global issues in 21 st century in the context of a population of more than 7 billion people on Earth along with their high pressure on natural resources for their basic needs and development. The irreplaceable role of biological diversity and importance of biodiversity conservation justified significant increase of protected areas through establishment of new natural reserves or expand available ones.

With three-quarters of total natural area occupied by hills and mountains, Vietnam is among top ten countries in term of biological diversity (Pham, 2005) and significantly contributes to biodiversity of Southeast Asia. However, national forest coverage has significant changes, in recent decades represented by a rapid decline from $43 \%$ in 1943 to $27 \%$ in 1990 (McNamara et al., 2006), and continuous increase up to 38\% in 2006 as a result of forest rehabilitation and plantation programs of Vietnam government between 1995 and 2010 (Forest Science Institute of Vietnam (FSIV), 2009). Because areas of low biodiversity reforested forest and plantation has rapidly increased whereas areas with rich and medium levels of biodiversity continued declining (FSIV, 2009; Tran, 2012), forest quality had declined (Morris et al., 2004). Started with the establishment of the 1st nature reserve or special-use forest (the Cuc Phuong national park) in 1962, until now, Vietnam has around 130 special-use forests (protected areas) covering approximately 2.2 million hectares, accounting for $6.7 \%$ of the total land area (FSIV), 2009). However, most protected areas exist on documents of their establishment only, with little or no effective management (ICEM, 2003 a). Biodiversity continues to reduce within and outside protected areas (PARC Project, 2006). The total number of endangered wildlife of the country increased from 721 species (Vietnam Red Book 1992-1996) to 882 species (Vietnam Red Book, 2007) (Ministry of Natural Resources and Environment (MONRE), 2008). Number of many rare and valuable plants and animals has been reduced seriously (Tran, 2012).

This negative correlation mentioned above first pointed out that protected areas system may have management problem. In another way, it's not enough infrastructure and security to prevent poaching, illegal extraction of timber as well as NTFPs and agricultural cultivation inside protected areas. Forest-dependent communities deeply understand that their survival and development are based primarily on collecting forest resources and keep 
extracting these resources. However, they have little knowledge in the fact that biological conservation is the only way to make forest resources become available for their long-term use. Conservation of biodiversity with involvement of local stakeholders in management or Community-based management (CBM) of natural resources has been applied worldwide (Hausner et al., 2012) with objective to co-operating improvement living condition of local people while conserving areas. This incorporation or co-management in protected areas combines traditional or indigenous knowledge in forest protection of local people with scientific knowledge of conservationists and/or natural resources managers in order to increase effectiveness of biodiversity conservation as well as environmental management in protected area (Child and Jones, 2006).

In Vietnam, at least three quarters of 76 million residents stay in rural areas and rely on agricultural production for their livelihood (ICEM, 2003). Among them, there is a number of ethnic minority group communities live in mountainous areas, especially in upland northern Vietnam. Their livelihoods are commonly based on subsistence production although there has been a change from traditional swidden agriculture to permanent agriculture (Turner, 2007). Their livelihoods are supported by extracting timber for building house, hunting wildlife and collection of wood, wild vegetables and fruit, medical plant, honey, eggs...

Establishment of protected area in any region of the country always leads to the restriction of local people from the use of natural resources inside the area (ICEM, 2003). It causes high pressure on these forest-dependent communities because their access to forest resources is limited. As a result, it restricts community development opportunities and increase poverty (West at al., 2006). Moreover, development of economic follow market orientation promotes purchasing goods especially forest products such as wildlife, herbal medical, orchard... Thus, currently illegal access forest for extracting resources and use forest land for cultivation of community living inside or nearby protected areas occur in many part of the world. These include logging, mineral extraction, agriculture encroachment, poaching, settlement construction... regardless of their conservation status (Secretariat of the Convention on Biological Diversity (SCBD), 2004).

Similar to most protected areas of the nation, the Hoang Lien national park (HLNP) located in Lao Cai and Lai Chau province in Northwest region faces conservation issues caused by livelihood activities of local community which negatively affect biological resource. Though being a major global centre of plant diversity as identified in the IUCN/WWF Centres of Plant Diversity project, the forest are threatened by timber and NTFPs extraction, illegal trade of endangered species and agricultural encroachment (Oldfield and Swan, 2003). The natural cover was seriously degraded due to unplanned field tilling, excessive hunting, fire caused by agricultural activities (Nguyen et al., 2008).

Local people living in the core zone of the HLNP belongs to several ethnic minority groups H'mong, Dao, Tay and Giay in which H'mong ethnic group has highest population (Frontier Vietnam, 1999). Their activities like agriculture (plant paddy rice in valleys, plant maize on hillside, develop home garden, grazing livestock freely around village or in the forest, cardamom cultivation help maintain food security and bring cash income for these households (Frontier Vietnam, 1999). However, it's clear that population growth will increase human demand and cause conversion from forest land to agricultural land, especially in case of H'mong ethnic group due to their high fertility. Although the total fertility rate of H'mong reduced from 9.30 children per woman in 1989 to 7.06 children per woman in 1999 and 4.96 children per woman in 2009, it is still double the national total 
fertility rate (United Nations Population Fund (UNFPA), 2011). The age at first marriage is also lowest among major ethnic minority groups in Vietnam represented by 19.9 years old for men and 18.8 for woman (UNFPA, 2011).

Besides agricultural activities depending on national park land area, local people are primarily forest-dependent. Timber is used as main material for house construction, furniture and agricultural tools. All household relies on firewood collected in the forest for cooking the whole year around and heating in winter season. Although tree cutting is banned inside the core zone and local people are allowed to collect dead wood only, live trees at different size are often cut for these purposes (Frontier Vietnam, 1999). NTFPs such as young bamboo shoots, edible roots and leaves, mushrooms, honey, medical plants, ornamental plants, animals are often collected for both home consumption and sale. In addition, a number of people from outside take advantages of local community to do tree cutting (always men in village), pay local labor at cheap price and then, sell timber in Sapa or export timber to China. Villagers also concerned about people coming from other areas to extract timber but they're unable to stop and prevent them (Frontier, 1999). Recently, ethnic minority participated in tourism in Sapa town located in the buffer zone of the HLNP (Frontier Vietnam, 1999). Their activities include selling goods such as hand-made clothes, traditional H'mong skirt, jewelry, forest products and drinks to tourists and provide several services such as tour-guiding, performing traditional music and supply accommodation in villages for visitors. However, limitation in Vietnamese language skills of ethnic group obstruct their participation in tourism and the local tourism industry in the region is totally belongs to Kinh business people (the largest ethnic in Vietnam) (Frontier Vietnam, 1999).

One livelihood activity identified as one of the greatest threats to biological conservation in the HLNP is cultivation of black cardamom (Amomum aromaticum) (Oldfield and Swan, 2003). This crop has a long history of cultivation in the Hoang Lien Mountains and provides cash income for ethnic minority households in the region (Buckingham and Petheram, 2004). To poor households, cardamom acts as a "household insurance" because they can use cash for buying food (Tugault-Lafleur and Turner, 2009). With average price of $60,000 \mathrm{VND} / \mathrm{kg}$ dried fruits (3.75 USD) and production $70-100 \mathrm{~kg}$ dried fruit per year in 2005 and 2008, each household in Lao Chai commune and Ta Van commune could earn 6 million VND (375 USD) (Tugault-Lafleur and Turner, 2009). Cardamom is grown under forest canopy, at the altitude of $1000-2000 \mathrm{~m}$ above sea level and cool condition. Cultivating cardamom requires the clearance of the ground flora and removal of up to $40 \%$ of the trees for cultivate this spice plant (Nguyen Nghia Thin, 1998). Local households also collect fuel wood and dry cardamom over fires in situ after harvesting (August to October) for two or three days because dried cardamom is easier to transport than the fresh cardamom fruit (Tugault-Lafleur and Turner, 2009). Accidental forest fires are easy to occur in the HLNP especially in dry season when leaf litter in forest is dry and wind is strong (Frontier Vietnam, 1999) when local people burn crops residues (maize), burn firewood for collecting charcoal to dry cardamom or cooking during stay in forest in crop season. The forest fire in the HLNP in 2010 destroyed about 700 ha of forest and the fire in March 2012 in Seo My Ty village, Ta Van commune was likely due to heating fire from cardamom drying (Report of the HLNP, 2012).

In fact, local authorities of Sapa district encouraged cardamom cultivation as one alternative cash crop when opium was banned in 1986 (Frontier Vietnam, 1999). Cardamom also grows in wild under natural condition with low plant density but cultivated cardamom brings higher fruit yield, therefore, ethnic groups in Northwest Vietnam 
expanded cardamom cultivation (Tugault-Lafleur and Turner, 2009). More than $90 \%$ of households in villages located in or near the Hoang Lien Mountains engage in cardamom cultivation (Buckingham and Petheram, 2004). To expand area of this crop, when forest with suitable conditions had become scarce, farmers continues grow cardamom in less suitable areas such as young generating forest (Buckingham and Petheram, 2004).

The conflict between livelihood of local people based on forest resources and forest conservation in the HLNP become more and more serious now with the extending of cardamom cultivated area. With three threats to the HLNP (clearance of vegetation cover, collection high amount of firewood used for drying fresh cardamom fruit in the forest which is likely to result in forest fire, trees in cardamom field steadily become stunt and dead whereas there is no development of small tree), cardamom plantation negatively affect forest resources of the HLNP. At present, the government does not allow growing cardamom under the canopy of natural forest ( Vu and Le, 2010). Extension service of Lao Cai province has recommended cardamom cultivators: 1) do not cut small tree, reduce cardamom density to promote growth of other plants and 2) bring home fresh cardamom fruit for drying to reduce firewood collections, however, it's not effective (Xuan Truong, 2012). Besides cardamom plantation, other livelihood activities of local people such as collection NFTPs and agriculture expansion also slow down conservation in the region. Using state power to force those forest-dependent communities out of the national park and exclude all their livelihood activities is a challenge. As a consequence, it required to have a research on current livelihood strategies of people in relationship with biological conservation and importance of cardamom. Based on that, alternative livelihood for cardamom cultivation can be identified to yield more sustainable livelihood opportunities for community living in the protected area.

\subsection{Objective, research question and hypothesis}

The overall objective of the study is to identify the relationship between livelihoods and conservation activities of local communities living in the HLNP, and to find potential livelihood strategies that improve biological conservation for sustainable development.

The specific objectives of the study are:

1. To identify livelihood strategies and resource use of local people living in the core zone and buffer zone of the HLNP?

Research questions:

a) What are characteristics of farming system and other livelihood activities of local people living in two different zones of the HLNP?

b) To what extent does the HLNP contribute to livelihoods of local people in two different zones?

Hypothesis: Households living in the core zone and buffer zone of the HLNP have different combination of livelihood activities.

2. To estimate the contribution of cardamom to income of different types of households and possible impacts on income of these households if cardamom cultivation in the HLNP is prohibited by the government.

Research questions:

a) Is it possible to construct different types of households in the HLNP based on demographic characteristics, land use, livelihood strategies and total net cash income?

b) How does cardamom contribute to income of households in the HLNP? 
c) What will be the economic losses face by local people if the government prohibits cardamom cultivation in the HLNP?

Hypothesis: Cardamom cultivation brings the highest profit among crops. If the government prohibits cardamom cultivation in the HLNP, income of local households will be significantly reduced.

3. To identify potential cash income generating activities of local people in the HLNP for sustainability of livelihood and conservation.

Research questions:

a) Are potential alternative income-generating activities available in the region?

b) How will local people change their livelihood activities if the government bans cardamom cultivation in the HLNP?

c) What were advantages and disadvantages of local households when they changed livelihood strategy in the past?

Hypothesis: Potential alternative livelihood activities are limited in the HLNP.

\subsection{Scope and Limitations}

Due to complex and varied topography, it was impossible to visit the entire study site for collecting data. It was also a fact that both local people living inside and nearby protected areas have forest-based livelihood activities and at different dependence on forest resources. However, this study focused on households which plant cardamom in the HLNP. To ethnic minority groups living in the study area, planting cardamom under forest canopy is a traditional livelihood and an economic importance for their households although it directly affects biodiversity values as well as limits success of biodiversity conservation programs in the protected area.

To identify potential alternative livelihood activities, this study focused on livelihood activities of local in the HLNP and adjacent areas which had same topography and climatic condition as well as similarity in social characteristics. Diversity of cash income sources and share of each source in total net cash income was considered because cardamom provided local people with cash.

Household level questionnaire survey, focus group discussion and key informant interviews were conducted as major information sources to access current status of cardamom cultivation, livelihood of local inhabitants and possible livelihood alternatives. The study was a mixed research including both quantitative approach and qualitative approach in the questionnaire, observations, and literature review.

Local people in the HLNP belong to several ethnic minority groups with different cultures. Their general Vietnamese language are not fluent especially woman. During the survey, it required having local interpreters and it partly affected accuracy of the information. Their education level is low, therefore, during household survey questions were simplified so that interviewees can answer.

Several respondents felt uncomfortable with questions about their personal information such as income, plot size, or quantity and/or value of timber and other valuable forest products taken from the national park as well as risks caused by cardamom drying in the park such as forest fire. It occurred especially when local government officers were present at the time of interview. 


\section{Chapter 2}

\section{Literature Review}

\subsection{Protected areas in Vietnam}

Vietnam occupies less than one percent of the world's land surface, however, this tropical country is one of the most biologically diverse nations of the planet and it supports approximately 10 percent of the world's mammals and bird species (Carew-Reid et al., 2010). With regard to number of species which have been identified and described, the country has 13766 floral species which consists of 11,373 vascular species and 2,393 nonvascular species (Nguyen Nghia Thin, 1999 cited in MONRE, 2008). Fauna kingdom on terrestrial includes 310 mammal species and sub species, 260 reptile species, 162 amphibian species, 840 bird species, more than 7,700 insect species and 307 nematode species. Moreover, there are 1,028 fresh water fish species, 1,438 micro algae species and around 800 non-skeletal animal species and 11,000 marine creatures (MONRE, 2008). In addition, between 1992 and 2002, a number of new species had been discovered and identified in Vietnam including 222 new floral species (Carew-Reid et al., 2010), 8 new mammal species, 3 new bird species, some reptiles and amphibian species along with many new genera and genus (MONRE, 2008). The discovery of four previously unknow large mammal species including Saola Pseudoryx nghetinhensis, Large-antlered Muntjac Muntiacus vuquangensis, Annamite Striped Rabbit Nesolagus timminsi and Black-crowned Barwing Actinodura sodangorum in 1999 have demonstrated the rich biological resources of Vietnam and increase attention of biological conservationists because many species can go extinct and disappear before human know their survivals on Earth.

Although forest cover of Vietnam had increased continuously between 1995 and 2004 and slightly ranged from $37 \%$ to $39 \%$ in recent years, forest fragmentation and degradation have increased. About two-thirds of natural forest was evaluated as poor secondary forest or regenerating whereas rich closed-canopy forest accounts for only $4.6 \%$ of total forest area in 2004 (Vietnam Environmental Monitor (VEM), 2005). Not only forest but also other habitats belonging to terrestrial ecosystems (forest, savanna, shrub land, desert, grassland, rocky areas...), wetland ecosystems (lake, pond, reservoirs...) and marine ecosystems (marine neritic, oceanic, intertidal and coastal...) of Vietnam have been degraded (MONRE, 2008). It was reported that 200,000 ha of extremely diverse mangrove forest in Ca Mau province in the period 1960-1970 has been destroyed a half due to aerial defoliants (Christensen et al., 2008). In addition, the area was continuously destructed to the bottom due to the over-exploitation and aquaculture development in several following decades. As a result, in 1980s the initial forest with richness in biodiversity of both flora and fauna in this Southern tip of Vietnam was converted to a monoculture forest of Rhizophora apiculata plant (Cuong, 1994 cited in Christensen et al., 2008). It is destruction along with degradation of natural ecosystems which cause biodiversity loss and degradation in the nation.

The establishment of Cuc Phuong Protected Forest (now Cuc Phuong National park) in Ninh Binh province with an area of 22,200 ha along with a buffer zone of 6,550 ha as early as 1962 was the first attempt of Vietnam government in forest protection and biological conservation (Nguyen Nhu Phuong and Stephen A. Dembner, n.d.). Since then until now, protected areas of Vietnam were extended represented by the establishment of new protected areas and/or the extension in boundaries of existed nature reserve. Especially, in 1986, the government decreed 73 Special-use Forest reserves which covered 770,000 ha 
(MARD, 1996 cited in Wege, D. C et al., 1999). The protected area size of Vietnam increased from 1.3 million ha or $4 \%$ of total land area with 87 special-use forests in 1986 (including 9 national parks, 47 nature reserves and 31 cultural-historic-scenic and environmental sites) to approximately 2.4 million ha with 122 special-use forests in 2002 in which there are 25 national parks, 48 nature reserves, 12 habitat/species conservation areas and 37 cultural-historic-environmental site (ICEM, 2003) as shown in Table 2.1.

Table 2.1: The system of protected area in Vietnam and their equivalent IUCN category

\begin{tabular}{|l|c|c|}
\hline Category & Number(2002) & Equivalent IUCN category* \\
\hline National park & 25 & II \\
\hline $\begin{array}{l}\text { Nature Conservation Area } \\
\text { Habitat/Species Conservation Areas (12) } \\
\text { Nature Reserves (48) }\end{array}$ & 60 & I and IV \\
\hline Cultural-Historic-Environmental Site & 37 & III \\
\hline Total & 122 & - \\
\hline Wetlands (Ramsar) & 1 & - \\
\hline World Heritage Site & 4 & - \\
\hline Man and Biosphere Reserve & 2 & \\
\hline
\end{tabular}

*IUCN. 1994. Guidelines for Protected Areas Management Categories

Source: After ICEM, 2003

The total protected area accounted for $7.4 \%$ of the country's total area (Table 2.2) and it was lower than recommendation of IUCN that each country aim to protect $10 \%$ of its area. It is easily to see that Vietnam protected area categories match with IUCN categories such as Vietnam national park is equal to IUCN category II, Vietnam nature conservation area is equal to IUCN category I and IV, and Cultural-Historic-environmental site fall under IUCN category III.

Table 2.2: Size of protected area in Vietnam by categories and total special-use forest

\begin{tabular}{|l|c|c|c|c|}
\hline Category & Average area (ha) & Area range (ha) & Total area (ha) & $\%$ \\
\hline National park & 34054 & $5998 \rightarrow 115545$ & 851361 & 35.61 \\
\hline Nature Conservation Area & 7646 & $50 \rightarrow 41930$ & 91753 & 3.83 \\
Habitat/Species Conservation Areas & 26236 & $500 \rightarrow 182000$ & 1259353 & 52.69 \\
Nature Reserves & 5072 & $300 \rightarrow 32051$ & 187668 & 7.85 \\
\hline Cultural-Historic-Environmental Site & & 2390135 & 100 \\
\hline Total protected area of Vietnam (ha) & $7.40 \%$ & \\
\hline Percentage of country area
\end{tabular}

Source: After ICEM, 2003.

Among these categories, nature reserves accounts for more than a half of total protected area and it was followed by national park which cover $35.61 \%$ of total area protected. With regard to size, except some special-use forest with large size, most units have small area, even a few hundred hectares as a consequence of highly fragmentation (Table 2.2). Moreover, protected areas are suffering different threats such as illegal forest extraction, agricultural encroachment, over exploitation of valuable products... despite improvements in law enforcement. 
Besides a number of protected areas under IUCN classification, Vietnam government has established several other categories which do not match IUCN protected area categories but meet the needs of both conservation and development. During the period from 1993 to 2002 Vietnam has one RAMSAR site, four World Heritage Sites and two Man and Biosphere Reserves (Table 2.3).

Table 2.3: Vietnam protected areas which is not under IUCN category

\begin{tabular}{|l|l|l|c|c|}
\hline Category & Name & Location & $\begin{array}{c}\text { Year } \\
\text { established }\end{array}$ & $\begin{array}{l}\text { Area } \\
\text { (ha) }\end{array}$ \\
\hline $\begin{array}{l}\text { Wetland site } \\
\text { (RAMSAR) }\end{array}$ & 1.Xuan Thuy & Nam Dinh, Thai Binh & 1995 & 12000 \\
\hline World Heritage Site & $\begin{array}{l}\text { 1.Ha Long Bay } \\
\text { 2.Hoi An Ancient Town } \\
\text { 3.Complex of Hue Monuments } \\
\text { 4.My Son Sanctuary }\end{array}$ & $\begin{array}{l}\text { Quang Ninh } \\
\text { Quang Nam } \\
\text { Thua Thien Hue } \\
\text { Quang Nam }\end{array}$ & $\begin{array}{r}1994 \\
1993\end{array}$ & $\begin{array}{c}43400 \\
-\end{array}$ \\
\hline $\begin{array}{l}\text { Man \& Biosphere } \\
\text { Reserves }\end{array}$ & $\begin{array}{l}\text { 1.Can Gio } \\
\text { 2.Cat Tien }\end{array}$ & $\begin{array}{l}\text { Ho Chi Minh city } \\
\text { Dong Nai, Lam Dong, } \\
\text { Binh Phuoc }\end{array}$ & 2000 & - \\
\hline
\end{tabular}

Source: ICEM, 2003

In addition to the protected area systems, the government has proclaimed a number of legislative instruments related to forest management such as "the Law on Environment Protection (2004), the Law on Protection and Development of Forest $(1991,2004)$ and the Ordinance on Crops and Domestic Animals (2004)". Vietnam also signed several international conventions, for examples: "the Convention of Biodiversity (1994), RAMSAR (1989) and CITES (1973)". Moreover, the government has also issued some related documents including "the Strategy for Sustainable Development in Vietnam (2004); the Strategy for National Environment Protection by 2010 and Orientation for 2020; the Plan for National Action on Biodiversity (1995, 2007); the Plan for National Action on Reinforcement of Control over Trade in Wild Animals and Plants by 2010; and the Plan for National Action on the Protection and Sustainable Development of Tidal Land" (FSIV, 2009: 8).

Government agencies involved in protected area management consist of the Ministry of Planning and Investment, Ministry of Agriculture and Rural Development, Ministry of Fisheries, Ministry of Natural Resources and Environment, Ministry of Culture and Information, Vietnam National Administration for Tourism, and the Provincial People's Committees. The Vietnam Environment Protection Agency (VEPA) of the Ministry of Natural Resources and Environment has responsibility in managing RAMSAR wetlands; a series of proposed wetland sites and Man and Biosphere Reserves while UNESCO World Heritage Sites are under management of the Ministry of Culture and Information and involved provinces (ICEM, 2003).

Despite achievement in improving protected area network, protected areas and biological conservation in Vietnam faces to some issues, for instances: insufficient funding, habitat fragmentation, limitations capacity in decentralization at provincial level and illegal extraction of forest resources (ICEM, 2003). Lack of funding in almost all protected areas does not ensure operation and maintenance costs and/or improve current infrastructure. Increase in population leads to increase in demand of food, shelter, fuel, clothes and other necessities. Protected areas become more and more fragmented as the last result. In recent 
years, conflict between human and wildlife has increased in many regions of Vietnam. Conversion of forest land into agricultural land is main reason for habitat loss and it affected large mammals the most. Remaining elephant populations suffering to food shortage in small fragmented forest areas left go back to villages destroy houses and crops of local people. One more issue is that most protected areas are managed at provincial level. This decentralization strategy is probably effective in the long-run but it does not ensure to solve problems and uncertainties in short-term. Strategies to deal with these issues are (1) integrating protected area benefits into development plans to reduce conflict between natural resources conservation and development of different sectors and (2) linking protected areas with each other through establishing corridors to reduce fragmentation as well as management cost.

\subsection{Background of livelihood}

Livelihood can be simply understood as "job", "profession", "making a living", "securing the basic necessities to life", "support a family"... However, this way of understanding only describes one of basic ways which humans use to ensure their survival and well-being while it is more complex and diverse. In 1991, Chambers and Conway suggested a definition of livelihood at household level as in the following:

"A livelihood comprises the capabilities, assets (stores, resources, claims and access) and activities required for a means of living: a livelihood is sustainable which can cope with and recover from stress and shocks, maintain or enhance its capabilities and assets, and provide sustainable livelihood opportunities for the next generation; and which contributes net benefits to other livelihoods at the local and global levels and in the short and long term." (Chambers and Conway, 1991)

Scoones (1998) proposed a modified definition:

"A livelihood comprises the capabilities, assets (including both material and social resources) and activities required for a means of living. A livelihood is sustainable when it can cope with and recover from stresses and shocks maintain or enhance its capabilities and assets, while not undermining the natural resource base"

and it is adopted by British Department for International Development (DFID) later.

Table 2.4: Five categories of livelihood assets

\begin{tabular}{|l|l|}
\hline Human capital & Skills, knowledge, health and ability to work \\
\hline Social capital & $\begin{array}{l}\text { Social resources, including informal networks, membership of } \\
\text { formalized groups and relationships of trust that facilitate co-operation } \\
\text { and economic opportunities. }\end{array}$ \\
\hline Natural capital & Natural resources such as land, soil, water, forests and fisheries \\
\hline Physical capital & $\begin{array}{l}\text { Basic infrastructure such as roads, water and sanitation, schools, ICT, } \\
\text { and producer goods, including tools, livestock and equipment }\end{array}$ \\
\hline $\begin{array}{l}\text { Financial } \\
\text { capital }\end{array}$ & $\begin{array}{l}\text { Financial resources including savings, credit, and income from } \\
\text { employment, trade and remittances. }\end{array}$ \\
\hline
\end{tabular}

(Source: Eldis, 2000.)

As stated by Ellis (2000),

"A livelihood comprises the assists, the activities and the access to these 
(mediated by institutions, social relations and organizations) that together determine the living gained by the individual or households".

Livelihood assets mentioned in definitions above can be tangible such as resources, food store or cash saving or intangible such as claims for food, access to information, employment opportunities and health care...etc (Chambers and Conway, 1991). Livelihood assets are divided into five groups which are natural, social, human, physical and financial. Any household, even the poorest one is wealthy in at least some of these capitals.

According to this complex nature of livelihood, a rural household often has livelihood strategy made up of a number farming activities, off-farm activities and natural resources extraction to ensure survival and prosperity (Sherbinin et al., 2008) which are created based on how the household combine their livelihood assets. For instance, local people living in a remote forest area often depend on forest for their livelihoods (extract timer, hunting wildlife and gathering NTFPs...), use medical plant found in forest to deal with sickness and diseases because they have strong access to forest resources and mutual relationship in their community, indigenous knowledge of their areas but limited access to information, education and health services (Messer and Townsley. 2003). Moreover, they will have difficulties in adaptation to changes brought by outside influences such as establishment of a protected area or a hydro power dam project in their areas.

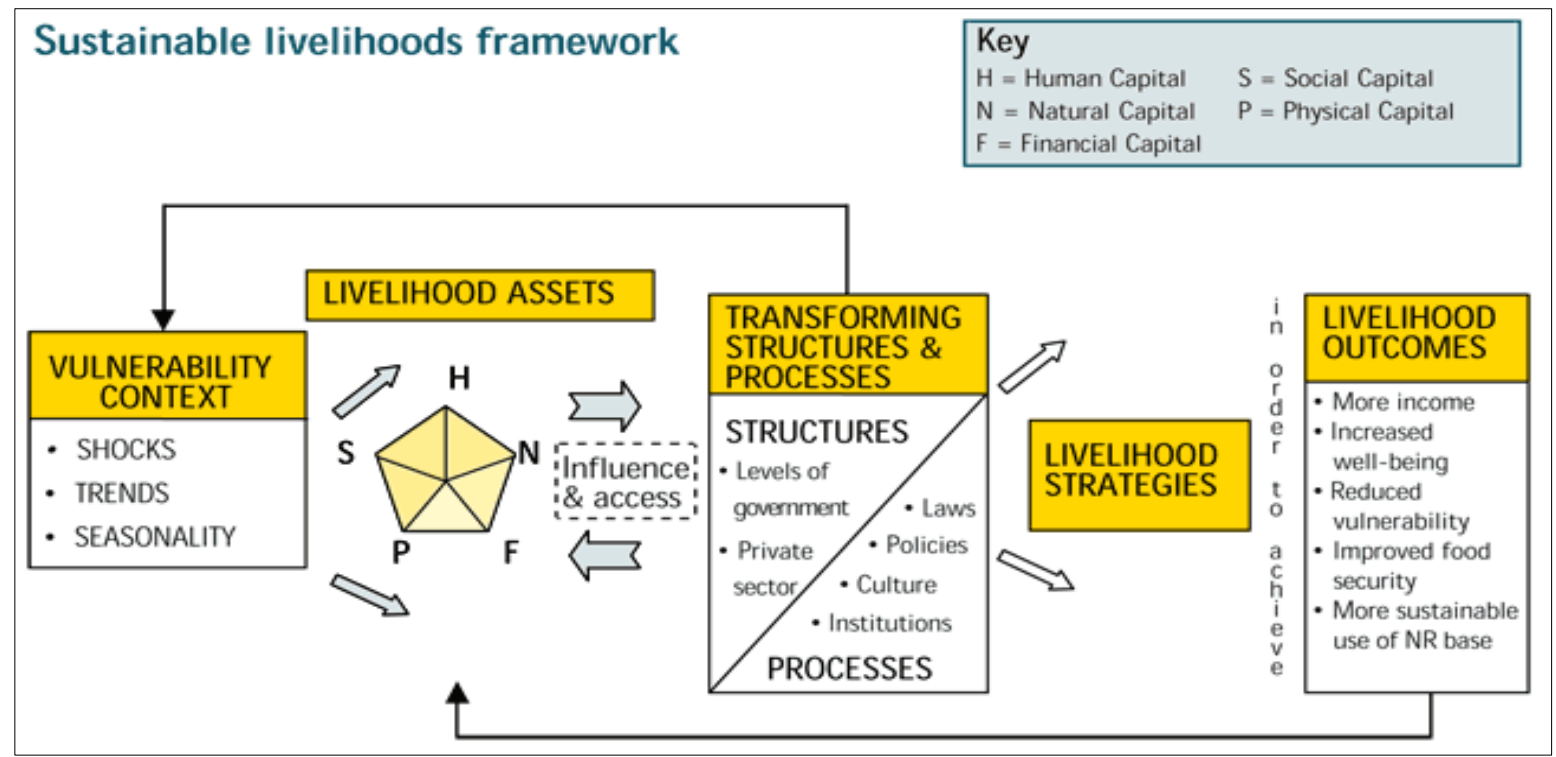

Source: Department for International Development (DFID, 2000).

Figure 2.1 Framework of sustainable livelihood analysis

Idea of sustainable livelihood was introduced as early as the beginning of 1990 s by the Brundtland Commission on Environment and Development. Then, the concept was expanded by the 1992 United Nations Conference on Environment and Development aiming at poverty eradication (Krantz, 2001). The framework of sustainable livelihood developed by the Department of International Development (DFID) (see Figure 2.1) helps improve understanding livelihood of poor people. The framework incorporate all elements of people's livelihood, put human at center of development and their livelihood opportunities depend on the combination of five different livelihood assets, not only one kind of asset (DFID, 1999). It determines who gains asset, which type of assets that person gains and assess how several factors such as vulnerability context, institutions, cultures and 
laws affect the way people combine and use their assets to form livelihood their strategies and achieve their objectives (Carney, 1998). In brief, the SLA “...depicts stakeholders as operating in a context of vulnerability, within which they have access to certain assets. Assets gain weight and value through the prevailing social, institutional and organizational environment (policies, institutions and processes). This context decisively shapes the livelihood strategies that are open to people in pursuit of their self-defined beneficial livelihood outcomes." (Kollmair and Gamper, 2002).

One more concept which is important in study livelihood is livelihood diversification. It is defined as "the process by which rural families construct a diverse portfolio of activities and social support capabilities in their struggle for survival and in order to improve their standards of living" (Eliss, 1998: 4). It is generally understood as a coping strategy or risk mitigating strategy of people in response to shocks and uncertainty (Baird and Leslie, 2013). The more livelihood strategies one household has, the more stable it is. Thus, diversifying livelihood strategies in rural areas is crucial for development in developing countries (Ellis, 2000).

\subsection{Application of sustainable livelihood framework in Vietnam}

Doi moi reforms initiated in 1986 in Vietnam with the goal of creating a socialist economy follow market orientation (Vuong et al., 2011) had a significant impact on the economic growth rate, hunger eradication and poverty alleviation (World Bank et al., 1999). Despite achievements in national development, poverty remains a serious problem throughout the nation where about $90 \%$ of total poor live in rural areas and access to natural resources under restriction (Sunderlin and $\mathrm{Ba}, 2005$ ). Among regions, Northern Uplands, North Central Coast and Central Highlands are inhabited by the poorest (Le and Nguyen, n.d >2007) who may have daily income lower than USD 0.5 per person (Pietrzak, 2010).

Livelihoods of most population residing in rural areas depend on basic natural resources such as land, forest, water bodies... and activities such as agriculture, forestry, aquaculture... for generating income (Tyler, 2006). These natural resources are used as common pool resources under the direct management of local authorities, for example: commune chairman. Accessing to the common pool for livelihood activities required a contract with local authorities; however, it is always affected by customary rights and relationships among people (CPR Research and Development group, 2007). The sustainable livelihoods approach helps list and arrange issues related to poverty (Carney, 1998). It has been applied in many research and practice in different locals of Vietnam by local government, development organizations and researchers to identify livelihood strategies of residents in the context of vulnerability and affecting factors, based on that, design development plans, support activities and apply them to improve livelihood and living condition of local people and reduce poverty ( $\mathrm{Vu}, 2012)$.

It is estimated that in Vietnam, mountainous areas accounts for three-four of the total land area and contain about $21 \%$ of population (Castella et al., 2002). Most ethnic minority groups of Vietnam (about 53 ethnic groups) reside in upland regions along national borders with neighbor countries (Yoshizumi, 2007). They often has higher rate of poverty than Kinh majority and it can be explained by two reasons: 1) they lack of physical capital, human capital and land and 2) their knowledge, custom or culture may result in lower return on these endowments (Ganeshamoorthy, 2010). It is studied that six pillars of disadvantages which combined to perpetuate poverty of ethnic groups in Vietnam include 
lower education, less mobility, less access to formal credit, less productive landholdings, lower market access/lower income for goods sold and stereotype and misconceptions (World Bank, 2009) (Figure 2.2). Each pillar has its own effect on ethnic minority people. For example, low education and less mobility reduce ability of ethnic minorities to approach new ideas, technology, new interventions in agricultural production as well as other industries. Less productive land negatively affect crop growth and crop yield, thus, reduce crop value and price of agricultural products. Those people primarily rely on subsistence agriculture for survival and face many difficulties in accessing market and formal credit both for selling their products as well as buying necessary input for production. All these pillars closely related to each other and form the cycle of lower income and poverty of ethnic minority groups (World Bank, 2009). The only way to reduce poverty is to improve their livelihood assets through carrying out projects on poverty alleviation.

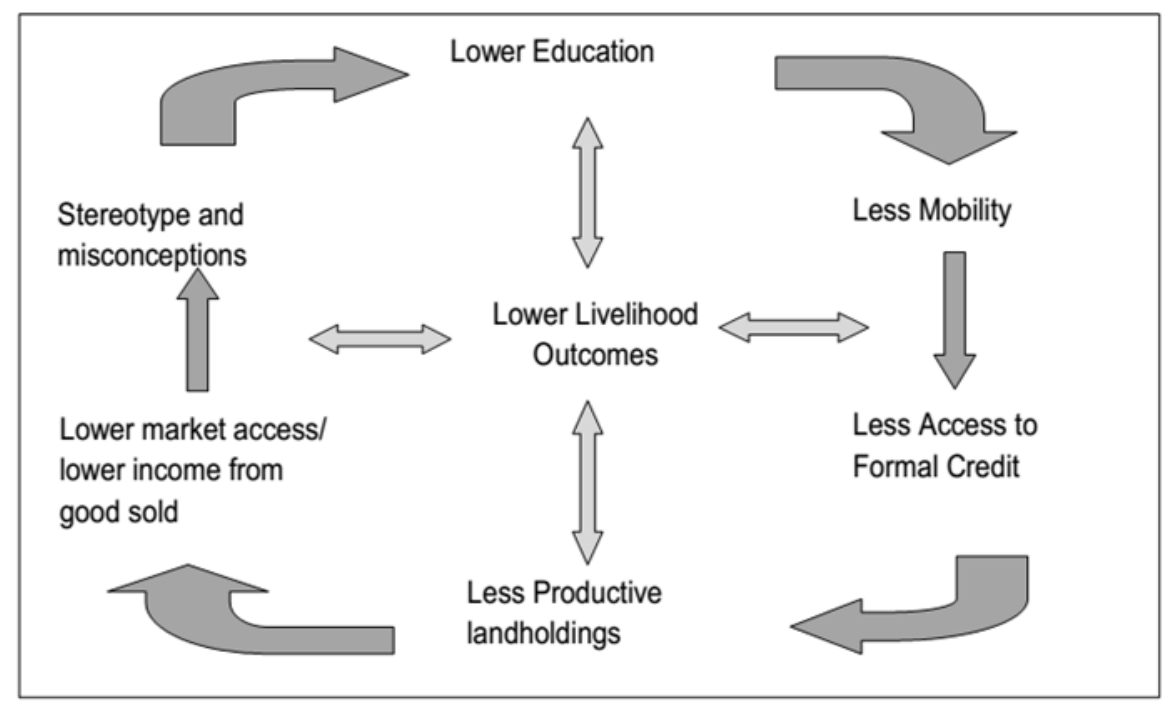

Source: World Bank, 2009.

Figure 2.2 The cycle of disadvantage for ethnic minorities

Most ethnic group in Vietnam depends on sloping land (natural asset) for agricultural production. Although they have limited areas of flat land to grow paddy rice, they often depend on "extensive hillside slash-and-burn cultivation system" to grow crops such as maize, cassava (Castella et al., 2002). In Bac Kan province, ethnic groups such as Dao, H'Mong, San Chay mostly use those crops mentioned above for home consumption and poultry. Their cash crops including soybean, sugarcane, peanuts and tobacco bring an important proportion of income for farmers. Similar, Thai and H'mong ethnic groups living in Son La province have same pattern, however, maize and cassava are their cash crops which provide income for farmers. Livestock such as buffalo, cow is raising with small number (about 2-3 buffaloes/cows per household in average) to maintain draught power. In emergency cases required large amount of money, they can sell their livestock for finance or take the best use of social capital such as borrow money from relatives and neighbors. Plantation of timbers like teak, pine tree and fruits have developed in both provinces follow government programs such as 327 Decree (Re-greening barren land" and 661 Decree "5 Million Hectares Reforestation Project". Forest is always divided into two kinds: protected forest and plantation forest. In Son La, both protected forest and plantation forest are allocated to individual households. To protection forest, household get paid to protect the forest and totally restrict in collections of forest products. In contrast, to plantation forest, households get financial support (in form of seedling) and they contribute labor in 
planting (Le and Ngiem, n.d > 2007). Households residing in villages which are near the roads can generate income through non-farm activities (Alther et al., 2002) by opening small business, for examples: selling products, water drink, restaurants, or shops like fixing motorbike, making handcraft..if they have knowledge and skill in these jobs. It can be concluded that local farmers take the best use of all livelihood assets to form different livelihood strategies such as on-farm jobs, off-farm jobs, forest-based livelihood activities and non forest-based livelihood activities to generate income for buying necessities whereas planting subsistence crops play an important role in ensure food security in the regions.

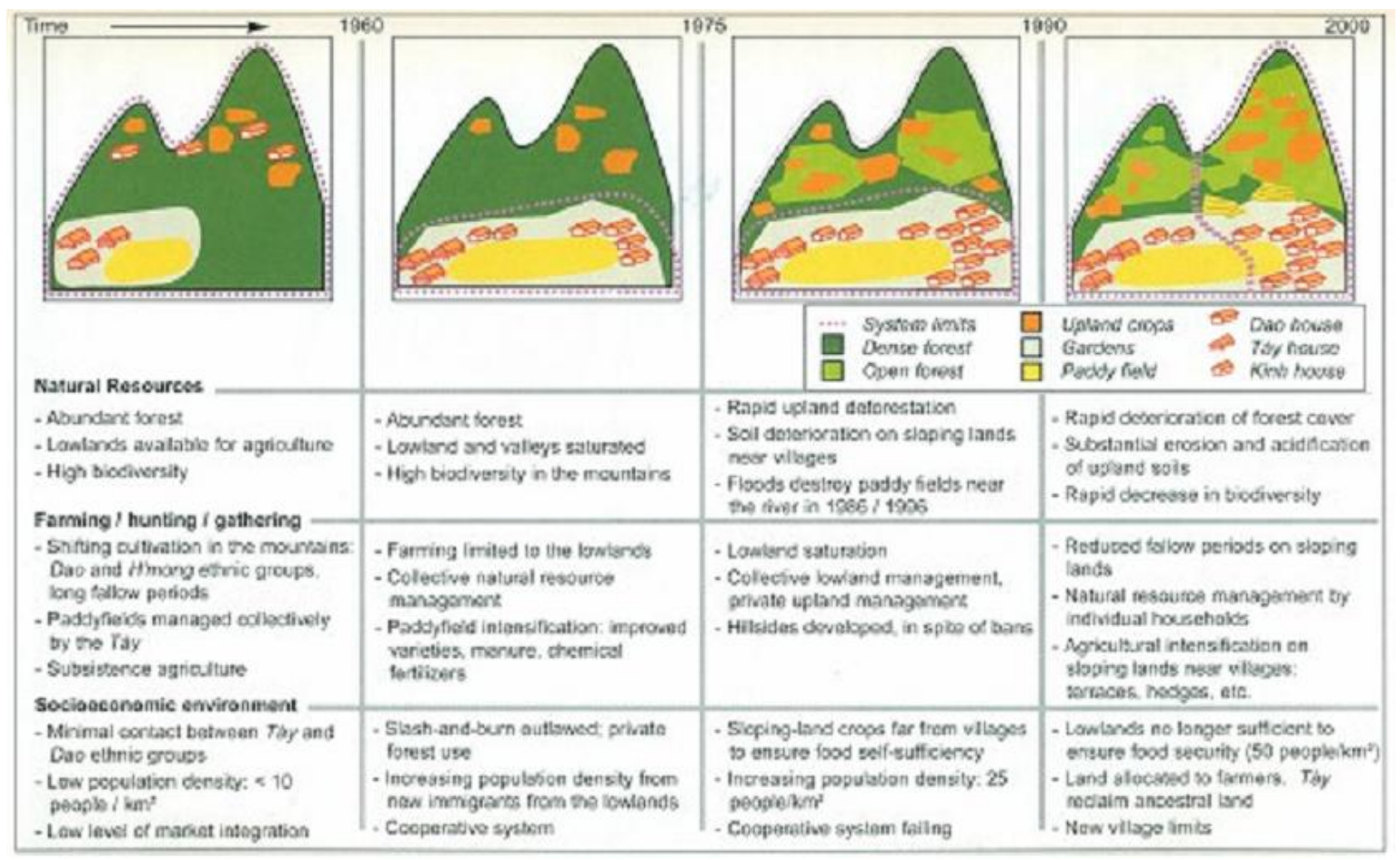

Source: Castella et al., 2002.

Figure 2.3 Agriculture and social-economic transformation in Ngoc Phai commune, Cho Don district, Bac Kan province from before 1960 to 2000.

Nevertheless, upland communities often face difficulties such as biophysical constraints (steep slopes, access difficulty, harsh climate), degradation of natural resources (land degradation due to mono-cropping of cash crop on sloping land, overuse of chemical fertilizer, soil erosion, flood), lack of infrastructure (communication, transportation network), low education, lack of health care ... etc (Donovan et al., 1997 cited in Castella et al., 2002). Many farm households in Yen Chau, Son La stated that they have to change from maize cultivation to planting cassava although price of maize is higher because the soil is depleted, not suitable for growing maize (interview conducted in 2011). Water availability changes led to the reduction in doing aquaculture. In contrast, in areas having optimum rainfall and soil moisture, local people can grow two crop season of maize in one year. Farmers are able to find new production practices that are suitable and sustainable in different context of institution and environment (Husson et al., 2001 cited in Castella et al., 2002) (see example in Figure 2.3).

Institutions policy and laws also influences livelihood assets and livelihood strategies. Recently, Vietnam government has carried out several rural sustainable developmental programs including The national program on poverty alleviation $(2006-2010)$ and The 
program on developing social-economic of extremely poor communes in ethnic minority groups residing areas and mountainous areas (also called Program 135 - period I (1998 2005) and period II (2006 - 2010). These programs have different development goals, nevertheless, they focus on hunger eradication, improve livelihoods, poverty alleviation, improve living condition of local people and reduce developmental gap among different regions and different ethnic groups. The program 135 works on 1848 communes and 3274 villages which are extremely poor in 51 provinces across the country. Through four projects: (i) Project to develop production and business, (ii) Project of develop infrastructure, (iii) Project to educate and improve human labor and (iv) Project to improve livelihoods, the program focuses on improve all livelihood assets of people such as support residents in production, improve knowledge and skill of ethnic communities, educate extension services in each locals, set up effective production plans to develop forestry economic, cash crop with high crop yield, develop poultry and livestock, build and improve infrastructure such as road from village to commune centre, construct hydrology systems for irrigation and domestic use, set up electric system for villages which have not electricity yet, building cultural house for communal activities depending on culture of each local, educate and improve authorities team and improve skill for young people, support services to improve education quality, increase health care...(Vietnam Department of Planning and Investment, 2012).

One of success in the Program 135 is poverty eradication in Sin Chai commune, Tua Chua district in Dien Bien province. The commune includes 12 villages inhabited by 4500 population belonging to H'mong ethnic group. Their livelihood depends on maize, upland rice and paddy rice. This commune belongs to Program 135 because the commune has no main road, no electricity, no hospital and no school. In addition, productive area has reduced significantly due to flood of the Black River. The program 135 has led to big changes in livelihood activities of local community. At present, the communes has diverse livelihoods including grow crops with high yield (maize, rice, soybean), expand area of tea, promote livestock with large number, develop handicraft products and market for develop both business and culture among villages (Vietnam Committee of Ethnic minority group, 2010).

With regard to protected areas, sustainable livelihood framework were also applied in both research and practice in the world and in Vietnam, aiming at finding solutions for achieving both sustainability of people and biological conservation (see Jiren et al., 2010; Biressue, 2009; Ghimire, 2008; Sanjay, 2002; MacEwin et al., 2007; Hoang et al., 2005...). Some conclusions are: It is concluded that paying attention on sharing responsibility and benefits among stakeholders coincided with improve livelihood of local people in national parks is crucial in biological conservation (Biressue, 2009; Ghimire, 2008). "Conservation and development are linked. Protected areas can provide development opportunities for communities"(Furze et al., 1996). Focusing on indigenous community and their livelihoods is necessary for conservation activities in protected areas (Sanjay, 2002).

\subsection{Linking livelihood and conservation in protected area}

Establishment of protected areas is considered as "the chief strategy" of global to conserve biological resources (Perspha et al., 2010: 2918), but restriction to access forest has serious impact on livelihood of forest-dependent community, especially the poorest group (Tumusiime et al., 2011). Cost paid by local community includes both indirect loss from access to forest resources such as timber, fodder, NTFPs and direct loss associated from crop and livestock depredation due to animals in protected areas) (Sekhar, 2003). It results 
in conflict between demand of conservation and demand of livelihood and question of synchronize these two objectives (Salafsky and Wollenberg, 2000). It is essential to understand the relationship between livelihood and conservation or poverty eradication and conservation, livelihood and management, conservation and development. Nevertheless, the relationship is dynamic and complicated, and locally specific and it is difficult to find a framework to examine that relationship (Nyaupane and Poudel, 2011).

Table 2.5: Types of forest dependency in Vietnam

\begin{tabular}{|c|l|}
\hline Type & \multicolumn{1}{c|}{ Description } \\
\hline 1 & $\begin{array}{l}\text { Poor communes and villages located in the remote, upland and border areas that } \\
\text { contain large amounts of land that is legally designated as protection forest, and } \\
\text { which are generally remote from industrial commercial opportunities. A feature of } \\
\text { these 'forest dependent' areas in the uplands is that they are amongst the poorest } \\
\text { regions of the country in terms of the depth of poverty, as well as containing high } \\
\text { numbers of ethnic minority people }\end{array}$ \\
\hline 2 & $\begin{array}{l}\text { Areas where State Forest Enterprises (SFEs) or Watershed Forest Management } \\
\text { Boards are the primary land holders, and where particular circumstances apply for } \\
\text { existing/former SFE employees and indigenous communities in these areas. }\end{array}$ \\
\hline 3 & $\begin{array}{l}\text { Communes and villages located on the borders of or within Special Use Forests, } \\
\text { National Parks and protected areas of high biodiversity value, where special } \\
\text { regulations and prohibitions apply with respect to land allocation and use of forest } \\
\text { products }\end{array}$ \\
\hline 4 & $\begin{array}{l}\text { Some rural midland areas where there are significant proportions of production } \\
\text { forest land allocated to farm households, where forestry related activities may } \\
\text { represent a considerable source of income for these households, and where the } \\
\text { main issues for livelihood development are related to supply chain management } \\
\text { and marketing. }\end{array}$ \\
\hline 5 & $\begin{array}{l}\text { In all rural areas of the country, a considerable number of poor people obtain } \\
\text { either occasional income or employment from the collection, transport, processing } \\
\text { and/or trading of forest products for local markets, in association with the informal } \\
\text { enterprise sector, or raw material supply for industrial enterprises. This represents } \\
\text { a substantial and largely 'hidden forest economy' that remains un-quantified in } \\
\text { income surveys and is not fully recognized in official statistics based on industrial } \\
\text { output. }\end{array}$ \\
\hline
\end{tabular}

Source: O’Reilly, 2005

In general, local people who rely on forest for their livelihood is called forest-dependent community. However, it is essential to distinguish between people based on their forest dependency because some households totally or mostly depend on forest resources and have no alternative livelihood whereas some have other sources of income beside their forest-based livelihoods (Byron and Arnold, 1997). Among different livelihood strategies of one household, some activities may have closer relation to forest and biodiversity more than other, meaning have higher forest dependency. Dependency also can be divided based on different in geographic situation, type of forest and institutional of the forest because these factors affect forest access and resources use of people (see Table 2.5 in the following describes five main context of forest dependency in Vietnam).

In another way, linkages between livelihood and conservation have been divided into five 
dimensions including species dependence, habitat dependence, spatial dependence, temporal dependence and conservation association (Salafky and Wollenberg, 2000) as follows:

“a) Species dependence: dependence of the livelihood activity on maintaining species.

b) Habitat dependence: dependence of the livelihood activity on maintaining habitats

c) Spatial dependence: percentage of the site on which livelihood activity depends

d) Temporal dependence: period and frequency of biodiversity use on which the livelihood depends

e) Conservation association dependence: dependence of the livelihood activity on associated conservation values also called externally created incentives such as green marketing” (Salafsky and Wollenberg, 2000).

Each livelihood activity has different level of dependence on forest resources in each dimension mentioned above, but, the principle is the more species/habitat/spatial/temporal /conservation association that an activity relies on, the greater the degree of linkage because this activity will be more impacted if the biodiversity of the area is damaged. If local households understand that their livelihood activity is linked to forest resources, then they will take action to protect forest and conserve biodiversity. In contrast, if they do not realize linkage, then they will not take any action (Salafsky et al., 1999).

Through the development in approach of protected area management, there have been three approaches of linkage between livelihood activities and conservation: no linkage, indirect linkage and direct linkage (Biodiversity Conservation Network (BCN), 1997). Each approach has its own positive and negative sides which determine applicable condition (Salafky and Wollenberg, 2000).

(a) No Linkage: Protected Area Strategy

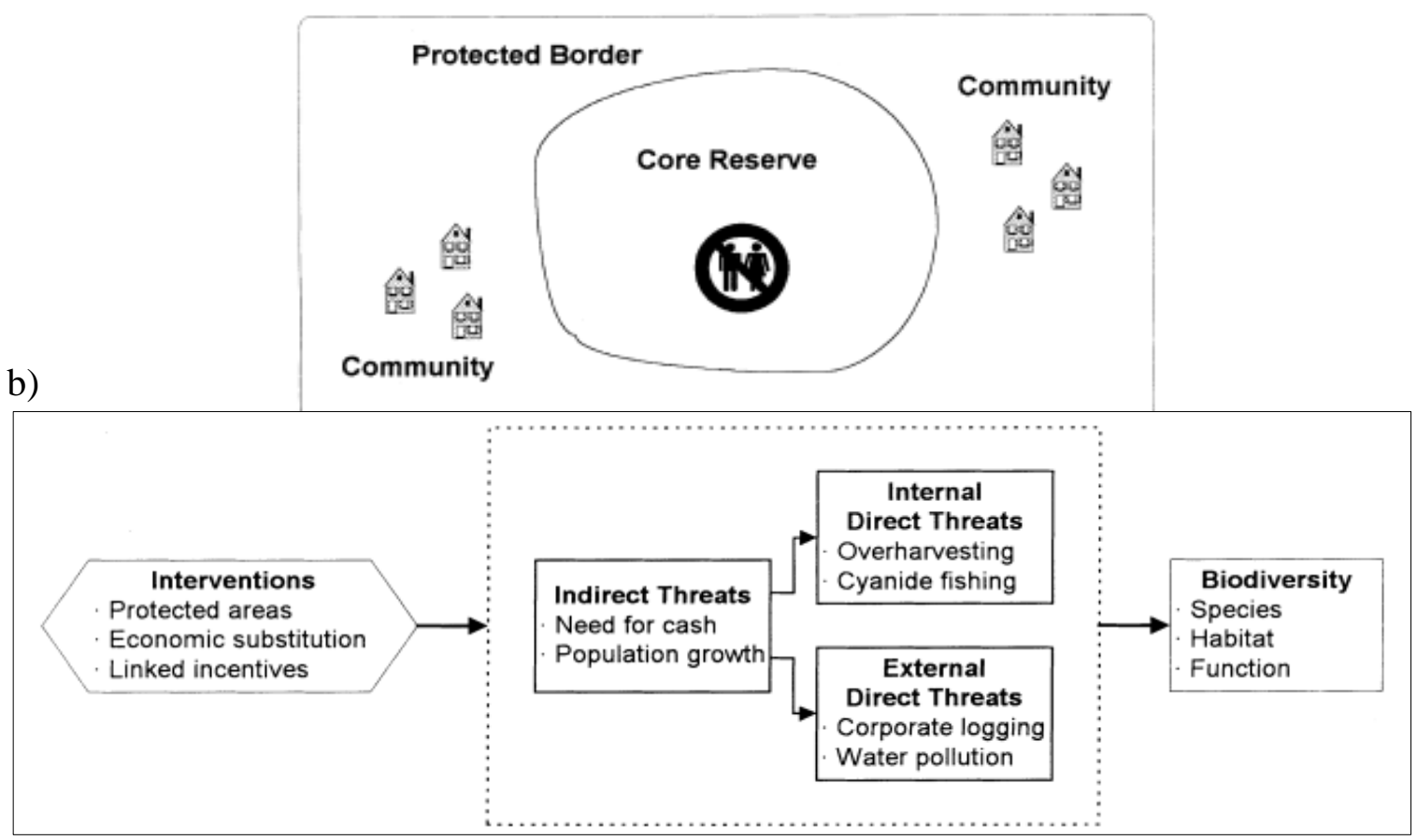

Source: BCN, 1997 and Salafky, 1998; Salafsky, 1999.

Figure 2.4: Scenario of no linkage between livelihood and conservation and its framework

The first approach also the common approach is the displacement of people for biodiversity conservation. It refers to the protected strategy, meaning creation of protected 
areas goes with excluding livelihood activities of local people (McNeeley and Miller, 1984). Protected areas have strictly defined boundary in which plants and animal stay and consumptive use of these resources is not permitted. Local people are prohibited from access to resources inside the boundary (Figure 2.4a). There is no linkage between livelihood and conservation in this approach (Salafky and Wollenberg, 2000). However, with increase of population and basic needs for survival and development, local people do not stop accessing and using resources in the protected areas. They become one of internal threats to biological resources (see Figure 2.4b). This is similar to neo-Malthusian theory which referred to the over population and consumption which lead to forest loss and natural resources degradation (Adger et al., 2001).

b)
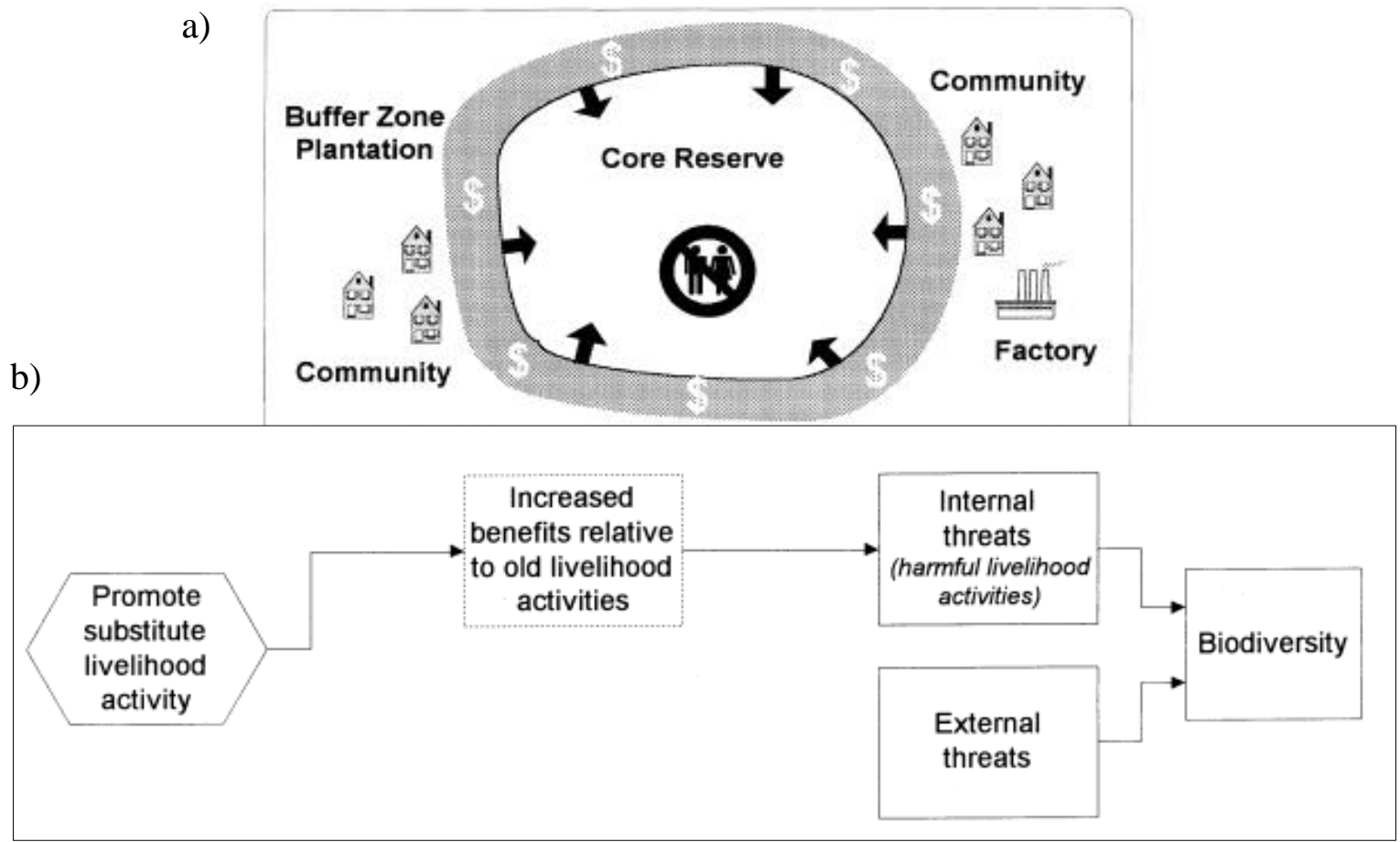

Source: BCN, 1997 and Salafky, 1998; Salafsky, 1999.

Figure 2.5. Scenario of indirectly linking livelihood and conservation and its framework called economic substitution

The second approach is conservationists and local community work together to make economic development inside or nearby protected areas for achieving both livelihood improvement and conservation. It could be described by the model of one biosphere reserve in which there is a core zone surrounded by a buffer zone (Figure $2.5 \mathrm{a}$ ). Extraction of forest resources in core zone is prohibited where as it is allowed in limitation in buffer zone. This approach showed indirect linkages between livelihood and conservation. Suitable conservation model for this approach is the economic substitution model, which means reducing dependence of local people on biological resources through substituting alternative conservation-oriented livelihood activities (Salafsky and Wollenberg, 2000) (Figure $2.5 \mathrm{~b}$ ). Alternative economic activities provided to local people will reduce farmer's traditional livelihoods which cause damage to forest resources (Brown, 2002). However, implementing this indirectly linked approach is difficult because economic values gained from livelihood activities in buffer zone often leads to expansion of buffer zone and decrease the area of core zone. As a result, it does not stop threats to biodiversity (Salafsky and Wollenberg, 2000) and it may accelerate destructive practices (Langhoiz, 1999 cited in Brown, 2002). 
The third approach developed in 1990s was one more effort of biological conservationists in linking conservation and local livelihood. Because livelihood activities of local people always based on forest resources, livelihood is directly linked with biodiversity to develop the dependent relationship between forest and people (BCN, 1997). There is no division of core zone and buffer zone. Local people are allowed to earn for living inside the area and given opportunity to benefit directly from the biological resources (Figure 2.6 a). For example, conservationists may help local household build a NTFPs harvesting enterprise, tourism enterprise or development of local institution to help foster profit sharing. It possibly creates incentives to prevent external threats to biodiversity. Internal threats is also countered because local stakeholders are provided with attractive livelihood strategies and steadily reduce livelihood activities damage biodiversity The direct link between biodiversity and livelihood helps closes the loop, makes system self-functioned (Figure 2.6 b) (Salafsky and Wollenberg, 2000).

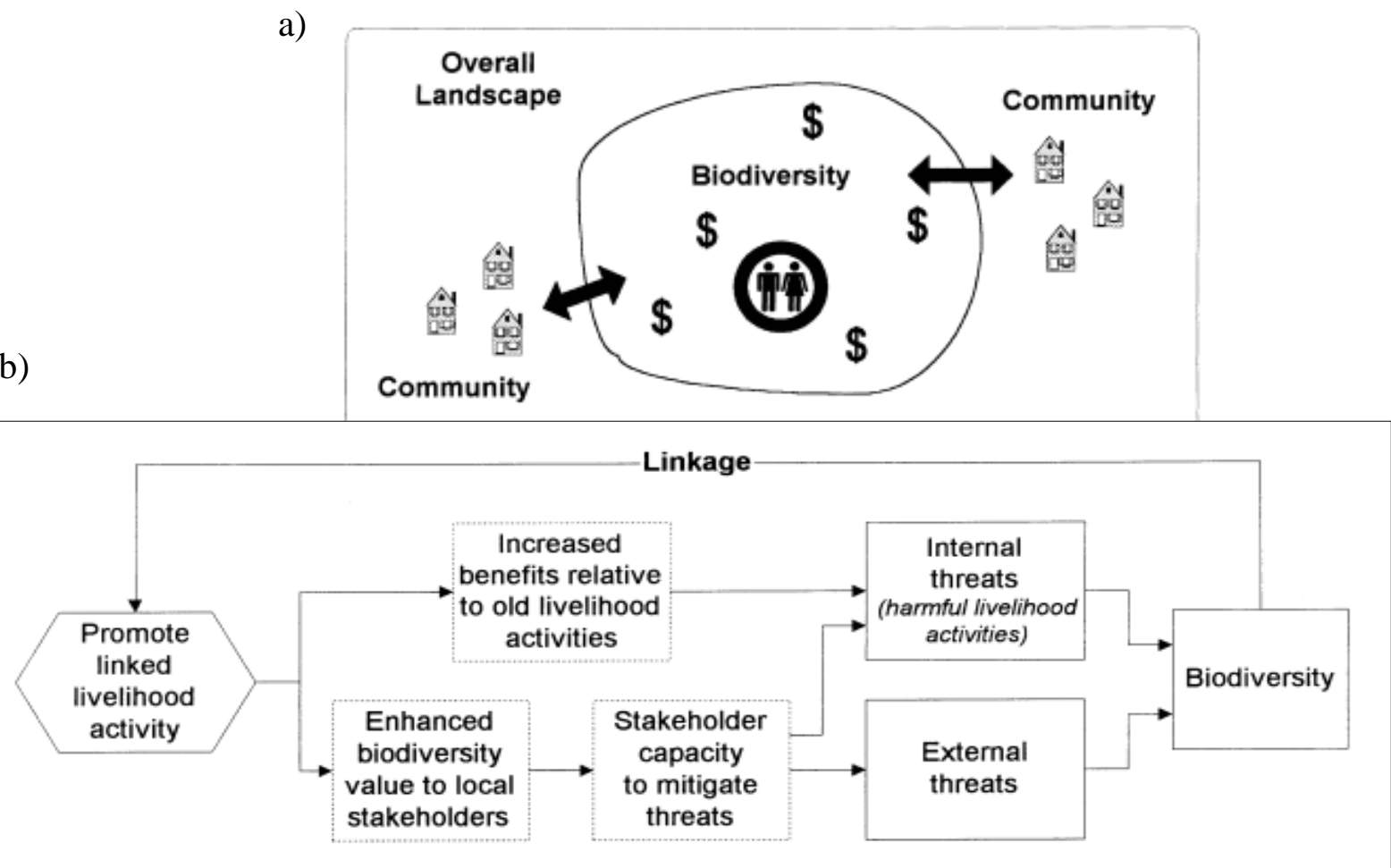

Source: BCN, 1997 and Salafky, 1998; Salafsky, 1999

Figure 2.6. Scenario of directly linking livelihoods and conservation and its framework called Linked incentive strategy

Nyaupane and Poudel (2011) stated that the direct linkage model developed by Salafsky and Wollenberg (2000) is the ideal relationship between conservation and development because it covers both theoretical and practical aspects of linkages. However, it will be the most effective if different strategies are combined in conservation of one natural area. It may include a strict protected area in one part, indirect linked incentives strategy in the second part along with direct linked incentive in the third part of one natural area (Figure 2.7). Increase environmental awareness of residents is also important. This mixed approach ensures both conservation objective of protected areas and development of local community. 


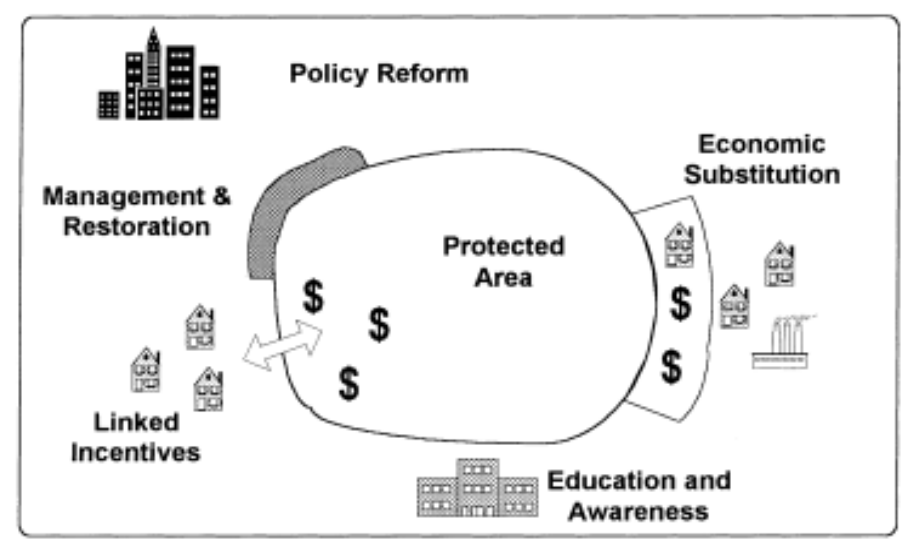

Source: Salafsky, 1998

Figure 2.7.Conservation requires a combination of different strategies

Several conservation approaches which focus on linkage between conservation and livelihood/conservation and development in practice include Integrated Conservation Development Projects (ICDPs), community conservation initiatives and wildlife utilization projects, all of which were based on direct linkage. All these approaches are based on direct linkage between conservation and development; however, each has its own principles and difficulties (Table 2.6)

Table 2.6 Some approaches in linking conservation and development in practice

\begin{tabular}{|c|c|c|c|c|}
\hline Approach & $\begin{array}{l}\text { Assumed } \\
\text { linkage }\end{array}$ & Agenda & Principles & Difficulties \\
\hline $\begin{array}{l}\text { Integrated } \\
\text { conservation } \\
\text { and } \\
\text { development } \\
\text { projects } \\
\text { (ICDPs) } \\
\text { (Started } \\
\text { 1980s) }\end{array}$ & $\begin{array}{l}\text { Direct } \\
\text { and } \\
\text { indirect } \\
\text { linkages }\end{array}$ & $\begin{array}{l}\text { "People- orientated } \\
\text { conservation" but } \\
\text { still based on } \\
\text { protected areas - } \\
\text { remains } \\
\text { conservation - } \\
\text { driven }\end{array}$ & $\begin{array}{l}\text { Need to get people } \\
\text { "involved" in protected } \\
\text { areas } \\
\text { Assumes conservation } \\
\text { and development are } \\
\text { complementary } \\
\text { Conservation as } \\
\text { "community outreach". }\end{array}$ & $\begin{array}{l}\text { Based on existing } \\
\text { protected areas }\end{array}$ \\
\hline $\begin{array}{l}\text { Community- } \\
\text { based } \\
\text { conservation } \\
\text { - 1990s }\end{array}$ & $\begin{array}{l}\text { Direct } \\
\text { linkage }\end{array}$ & $\begin{array}{l}\text { "people-based } \\
\text { conservation" } \\
\text { reflected in populist } \\
\text { conservation and } \\
\text { development } \\
\text { discourses }\end{array}$ & $\begin{array}{l}\text { Participation as a key } \\
\text { process } \\
\text { Bottom-up and } \\
\text { grassroots approaches }\end{array}$ & $\begin{array}{l}\text { Assumes a simplistic } \\
\text { homogenous community } \\
\text { Who participates, how? } \\
\text { Does not address } \\
\text { fundamental causes of } \\
\text { biodiversity loss }\end{array}$ \\
\hline $\begin{array}{l}\text { Wildlife } \\
\text { utilization } \\
\text { and extractive } \\
\text { reserves - } \\
\text { 1990s }\end{array}$ & $\begin{array}{l}\text { Direct } \\
\text { linkage }\end{array}$ & $\begin{array}{l}\text { "Use it or lose it". } \\
\text { Neo-liberal agendas } \\
\text { - making } \\
\text { biodiversity pay, } \\
\text { plus empowerment }\end{array}$ & $\begin{array}{l}\text { Recognition of } \\
\text { community rights } \\
\text { benefit sharing }\end{array}$ & $\begin{array}{l}\text { Requires explicit } \\
\text { clarification of property } \\
\text { rights } \\
\text { Economic feasibility of } \\
\text { project often suspect } \\
\text { Difficult to define } \\
\text { sustainable off take or } \\
\text { harvesting levels. }\end{array}$ \\
\hline
\end{tabular}

Source: Brown, 2002 


\subsection{Linking biodiversity conservation, livelihood and tourism}

As mentioned at the beginning, tourism is closely related to protected areas and support financial to both conservation and management of protected area and local people living in or near by protected areas. It provides both local people and visitors with opportunities of non-consumptive use, sustainable use of biodiversity resources, and is is considered as the best strategy to improve the well-being of forest dependent community whereas pressure on forest resources is minimized (Hussain et al., 2012). Tourism has become a tool to improve the linkages between conservation and livelihood although the relationship between biodiversity conservation and tourism is complex, sometimes complementary and sometimes competitive (Nyaupane and Poudel, 2011).

Nyaupane and Poudel (2011) has identified five themes of linkage among biodiversity conservation, livelihood and tourism (Figure 2.8) as follows:

a) Empowerment

Tourism development and biological conservation enhance local people access to information, conservation education programs and access to forest and traditional use right which contribute to empowerment in term of both politics and society. The typical example is the establishment of buffer-zone community forest and formation of user groups which consist of several ten households, committees and council through elective representative. Local people participated in planning and decision-making at all levels.

\section{b) Capacity-building}

To engage in tourism, local people are required to have skills and knowledge to market and provide visitors with goods and services. Local people have opportunities to participate on capacity-building activities such as skill development training, leadership training, enhance livelihood and income generating activities, produce hand-made goods, especially for poor households and women. Tourism provide fund to open these training programs. In addition, it provides small loans to local households so that they can operate small-scale tourism business or other production activities...

\section{c) Economic-benefit}

Not only replace industries which cause land use and create consumptive use of biological resources, tourism also has create a market for local farm products and non-farm products. It provides job opportunities in tourism business and in operation of micro enterprises such as small restaurants, inns selling breakfast, souvenir shop... Moreover, revenue tourism and conservation also contribute to the collective economic and this money is spent on community development.

d) Biodiversity conservation and environmental service.

Protected areas support ecotourism activities such as bird watching, boating, camping, elephant riding,...Conservation programs help protect forest resources and ecosystem services so that these activities are maintained. Moreover, these programs also increase participation of local people and visitors in biodiversity conservation, protection of forest in buffer zone area, environmental awareness.

e) Amenities development

Sufficiency of infrastructure including local infrastructure, conservation infrastructure, tourism superstructure and development of tourism products(roads, bridges, communal buildings, electricity, water supplies, school, artificial lake, watch towers... are needed to support biodiversity conservation, improvement of livelihood and tourism development in 
the area. Preparation of fences in crop fields and gardens to avoid negative effects of wildlife to local people's crop and livestock are also necessary. (Summary from Nyaupane and Poudel, 2011).

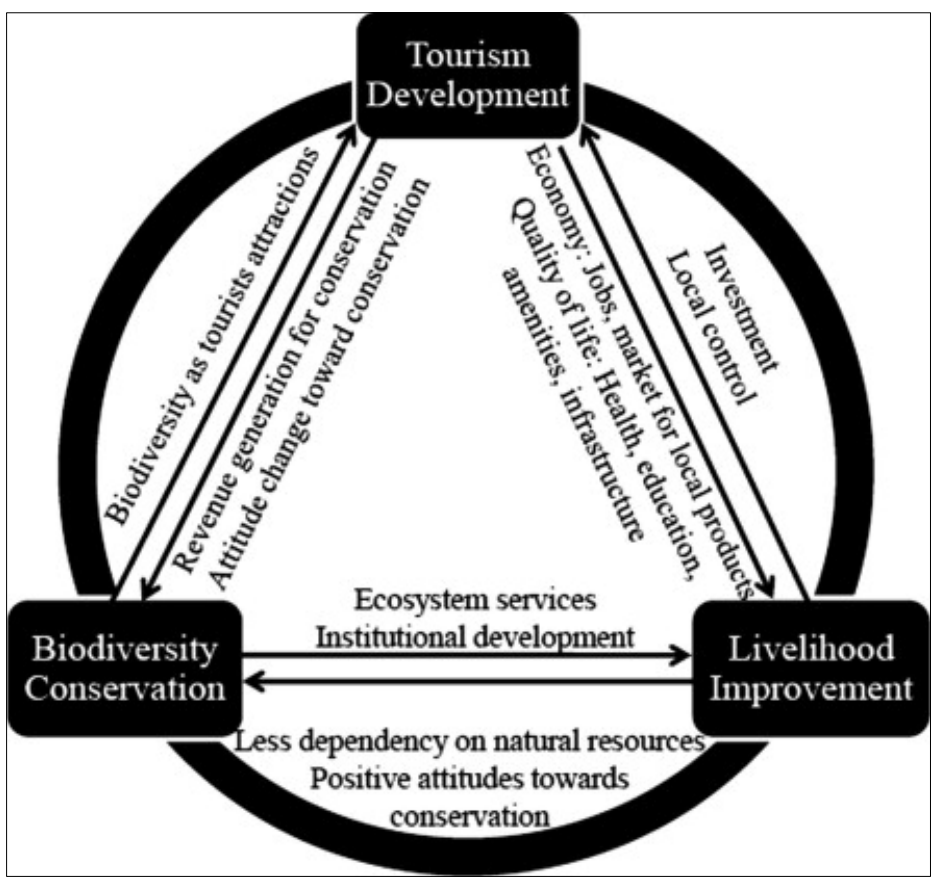

(Source: Nyaupane and Poudel, 2011)

Figure 2.8 Linkages among biodiversity conservation, livelihood improvement and tourism development

In theory, tourism contributes to conservation and development of local community. However, one of common problems of many protected areas which support tourism is that although total revenue from tourism is high, however, the revenue is "...neither equitably distributed among the service providers nor does it serve its primary objective of contributing to biodiversity conservation" (Hussain, 2012). Almost financial benefit belongs to service providers which have direct and indirect contact with tourists such as tour services, interpretation, hotel, restaurant, transportation, construction workers... whereas forest-dependent community which are mostly farmers, handicraft producer receive lowest financial benefit. It is also happened in Hoang Lien national park, Sapa district, Vietnam where this study will be carried out. Financial benefit of local residents may go up if the leakage mentioned above could be prevented. It is necessary to increase skill and knowledge of local people, support them to operate direct and indirect services to visitors, strengthen marketing of their products and local institutions so that they can compete with other service providers. Tourism can be an effective tool to improve linking between conservation and livelihood only when local communities living inside or nearby protected areas get their benefits, not share to other external groups (Hussain, 2012).

\subsection{Effects of cardamom cultivation on forest ecosystem}

Black cardamom (Amomum aromaticum) beloging to Zingiberaceae family is one crop growing in forested land in mountainous areas of several countries such as Vietnam, Lao, Burma and southwestern China. People started trading this queen of spice in Chinese imperial times (Buckingham and Tu, 2003 cited in Tugault-Lafleur and Turner, 2009). In Vietnam, cardamom is cultivated in several mountainous provinces close to the North 
border including Lao Cai province (Bat Xat, Sapa, Muong Khuong and Bac Ha district), Lai Chau province (Phong Tho, Than Uyen and Sin Ho district) and Ha Giang province (Vi Xuyen and Quan Ba district).

Cardamom is considered as one valuable NFTP which provides high income for households in poor villages of Lao Cai and Lai Chau provinces, Northwest Vietnam (SNV, 2008). In comparison to other crops in upland areas, at present, cardamom has many advantages such as high economic value, low investment cost and potential market. In 2001, the price of dried cardamom reached to $150000 \mathrm{VND} / \mathrm{kg}$ (7 USD) and $40000-60$ $000 \mathrm{VND} / \mathrm{kg}$ ( 2 - 3 USD) between 2002 and 2004. Many households earn about $30-50$ million VND (1400 - 2400 USD) per year from cardamom, thus, cardamom is evaluated as the cash crop of poverty alleviation and alternative crop for opium in highland regions (Le Van Thanh, n.d. >2002).

With regard to growth condition, cardamom is adaptive with mountainous areas of over $1000 \mathrm{~m}$ a.s.l where natural forest has. Cardamom requires shade (under forest canopy) and high humidity to grow and develop. Therefore, most cardamom cultivated field of local people locates in the core zone and buffer zone of the HLNP (SNV, 2008). This crop is considered as one of the most important factors for forest deterioration in this national park although forest canopy still remains and nutrients are not lost due to soil erosion (Birdlife International, 2001).

To plant cardamom, it requires clearing the ground forest cover. Comparing natural forest and forested land with cardamom cultivation, there is some difference in forest structure and canopy openness. The mean density of woody plants $(>=5 \mathrm{~cm} \mathrm{dbh})$ was $41 \%$ lower in cardamom plantation than natural forest. The mean densities of saplings $(<5 \mathrm{~cm} \mathrm{dbh}\rangle=$, $1.5 \mathrm{~m}$ height $)$ and tree seedlings $(<1.5 \mathrm{~m}$ tall $)$ in cardamom plantation were also lower than those kinds in natural forest from 3 and 2 times (Dhakal et al., 2012). Species richness of trees $>=5 \mathrm{~cm}$ dbh in same area was higher in natural forest than cardamom plantation. The concentration of $\mathrm{N}$ in top-soil layer of natural forest is also higher than forested land with cardamom cultivation. It is concluded that cardamom cultivation lead to the loss of small trees through clear ground cover and weeding (Dhakal et al., 2012) and it also prevent the reproduction of trees (Nguyen et al., 2008). When local people stop harvesting cardamom after 20-30 years plantation, the soil is not fertile anymore and there is no sapling growth. In Vietnam, local people dry cardamom using firewood in the forest. It not only leads to high amount of firewood collection during harvest season but also lead to accidental forest fire, especially in dry season (Frontier Vietnam, 1999). 


\title{
Chapter 3
}

\author{
Methodology
}

\subsection{Selection of study area}

Hoang Lien national park was selected to be a study area based on several considerations. Historically, it has rich forest and biodiversity which plays determinant part in livelihood of ethnic minorities living in that mountainous area. Secondly, the region has experienced changes in socio-economic conditions. In detail, the area has undergone a change from remote forest area to a protected area in 1986, and the protected area was expanded continuously since then until now, leading to changes in forest-people linkages. Population growth and shifting cultivation of local people led to conversion of forest land to agricultural and residential land. Opium cultivation was banned in the region. Moreover, recently a part of the buffer zone of the national park (Sapa town) has developed tourism which contributed to livelihood diversification in several villages. Thirdly, the park is a conflict hotspot between livelihood development and forest resource conservation. Income of local community living in core zone mainly obtained from exploiting forest products and cardamom cultivation, while they are among causes of biodiversity loss in the national park. In addition, the tradition of drying cardamom in the field leads to accidental forest fire which can affect thousand hectares forest in one day.

\subsection{Overview of Research Design}

This study used a combine of different method:

- Random sampling and purposive sampling were used for selecting study area, households for survey

- Secondary data collection from different sources such as published and non-published government and/or non-government reports, books, journals articles and working papers.

- Survey method for primary data collection including reconnaissance survey at the beginning of the research, structured questionnaires for household survey, key informant interviews, focus group discussion and visual observation.

\subsection{Data collection}

\subsubsection{Reconnaissance survey}

The study began with a reconnaissance survey in the national park to identify patterns of forest-people interactions, dependence on forest resources at different level (number of households has forest-based livelihoods), market features... The result of this survey helped identify main types of households in term of livelihood. And it was used as one basis for village selection for household survey in the next step of the study.

\subsubsection{Secondary data collection}

Secondary about the National park and households living inside the boundary was collected including:

- Data on organization of the park (core, buffer zone and periphery), map, resources status (land, water, forest cover, forest products ...), other reports and document related to the national park

- Administrative maps. 
Based on administrative map, national park boundary and administrative jurisdiction such as number of communes, villages inside each zone of the park... were identified.

- Communes/villages statistics such as ethnic groups, number of households, number of households which cultivate cardamom, structure of labor, land use, poverty statistics ... were obtained from annual report of people committee of each commune and village head of each hamlet. In addition, secondary data were obtained from publications of scientists working in different projects in the region. Moreover, there were a number of books, presentations and articles related to the topic available online.

Assessing these secondary data might be easy or difficult based on each kind of data and where to get them. It requires remembering that no data is truth. It was better to focus on getting the most useful data, not the true data.

\subsubsection{Key informant interview}

Key informant interview was carried out to investigate the history of the national park management and impact of forest conservation on local livelihood, agrarian and forest system in the park, farming system and farming calendar of local residents in different zone of the national park and potential product of villages and their economic efficiency.

It was addressed to officers in management board of HLNP, district people committee, agriculture department, forest department, agricultural extension and village head, elderly people at village level. Interviews will focus on resource mapping, interaction between resources and resource users, potential products of the regions, advantage and disadvantage to develop these products instead of cardamom. Appendix 1 lists guide questions for key informant interview to each groups mentioned above.

\subsubsection{Villages selection}

Three communes among four communes which have villages located in the HLNP were selected based on their diversity of livelihood activities after reconnaissance survey in the national park and key informant interview with the HLNP Management Board and District People Committee officers. After key informant interviews with Communal People Committee Officers, four villages in the buffer zone and two villages residing in the core zone of the HLNP were purposely selected to conduct group discussion.

After group discussion, two villages in the buffer zone and two villages in the core zone were selected for conducting the household survey. It was important to conduct household survey in both zones because (i) difference of villagers in two zone might include living location, land use, market; (ii) villagers in different zones might be dependent on forest follow different dimensions; (iii) cardamom is suitable for forested land in the core zone, meaning villagers in two zones might have difference relevance to cardamom cultivation; (iv) it would give diversity of livelihood activities which was an advantage in identifying potential alternative livelihood activities.

\subsubsection{Household survey}

A household survey was conducted in four selected villages using structured questionnaire and households were randomly selected. This survey focused on linkage between forestpeople in the park, current livelihood strategies of local community living in different zones of the national park and factors affecting these strategies, conservation activities of 
local rural and their participation in the national park management. The survey also focused on potential alternative livelihood activities and interest of local people, possible impacts when these alternative ones are introduced to different types of household, advantages and disadvantage when these alternative livelihood activities are developed in the region... The result of this survey helped identify potential products besides cardamom.

Respondent: The respondent must be the household head who has the most information about the household, household's livelihood, and has important role in decision-making. Sample: 15 households per village.

\subsubsection{Group discussions}

One group discussion was organized in each selected villages with participants include 10 people per group, including: village head, representative of woman union, representative of young union, representative of elderly union and 6 farmers from 35-50 years old.

Group discussion focused on:

- Participatory resource mapping (identify resource and resource users) and histogram mapping (recent history of village and evolution of resource use);

- Crop history and farming calendar

- Evaluation of cardamom cultivation in the farming system and livelihood of local people in term of important input, output, labor use, revenue, impacts on forest ground cover...;

- Identification of all potential products of the village based on four criteria: (i) be suitable for ethnic minorities' production condition; (ii) have market potential; (iii) be able to expand production toward market oriented; and (iv) be consistent with the orientation of local development. These products included traditional crops, fruits, handicraft products...

- Evaluation of possible alternative livelihoods (alternative cropping system, livestock, engage in tourism, selling traditional handicraft products...) through setting up and evaluating different livelihood models (experiences, constraints in adoption, potential to adopt, impacts of market factor...)

For every time collecting data, it requires to have standard report for data documentation. In each report, it must have general information of hamlet, commune, start date, any update, time spent on field/interview, language used (need local translator or not), related document... Description of the field work context such as context of communication (location, use of space, purpose and topic), participants (farmers, researcher, officers, respondent, local translator...) and some basic information about respondents such as gender, age, job... Methods for data collection were mentioned above. Field note, audio record, report based on audio recording, pictures and all related data source must be reported carefully. It helped to avoid mistakes and misunderstanding in the later periods when a huge amount of data of many households survey are collected.

\subsection{Data Processing and Data Analysis}

Both quantitative data and qualitative data were collected and there were differences in analyzing these two kinds of data. Quantitative data is represented by number. Evaluation of this kind of data is simply divided into distinct stages such as "instrument development, data collection, data processing and data analysis". The common way to analyze data is statistical analysis. In contrast, qualitative data is represented by words and two stages of data collection and data analysis are not temporally separated because for every piece of data collected, the process of making sense of the information began (Berkowitz, 1997). 


\section{- Quantitative data analysis}

Quantitative data collected from each group discussion, household survey or key informant interview will be taken descriptive statistical and analytical statistics. Frequency, percentage, distribution, mean, min, max and standard deviation were calculated.

Multivariate analysis will be used to categorize household typology. Households were classified hierarchically according to several criteria which are demographic characteristics, distance to the closest agricultural input provider and to Sapa town, land use area of rice and cardamom, total land use area, livestock, total net cash income, income diversification, reliance of the household on cardamom income, tourism income, income from forest resource extraction.... The number of typologies was set up based on the combination of Principal Component Analysis and Cluster Analysis. Sample weights were calculated the proportion of farm household falling into each type.

This study has objective to find out the reliance of local on cardamom cultivation, therefore, it is better to construct household typology for households which plant cardamom. Other households which do not plant cardamom will not rely on it and they will not be affected when cardamom is banned by state power.

\section{- Qualitative data analysis}

Qualitative data was analyzed follow three steps in framework developed by Miles and Huberman (1994) including data deduction, data display and conclusion \& verification (Figure 3.1).

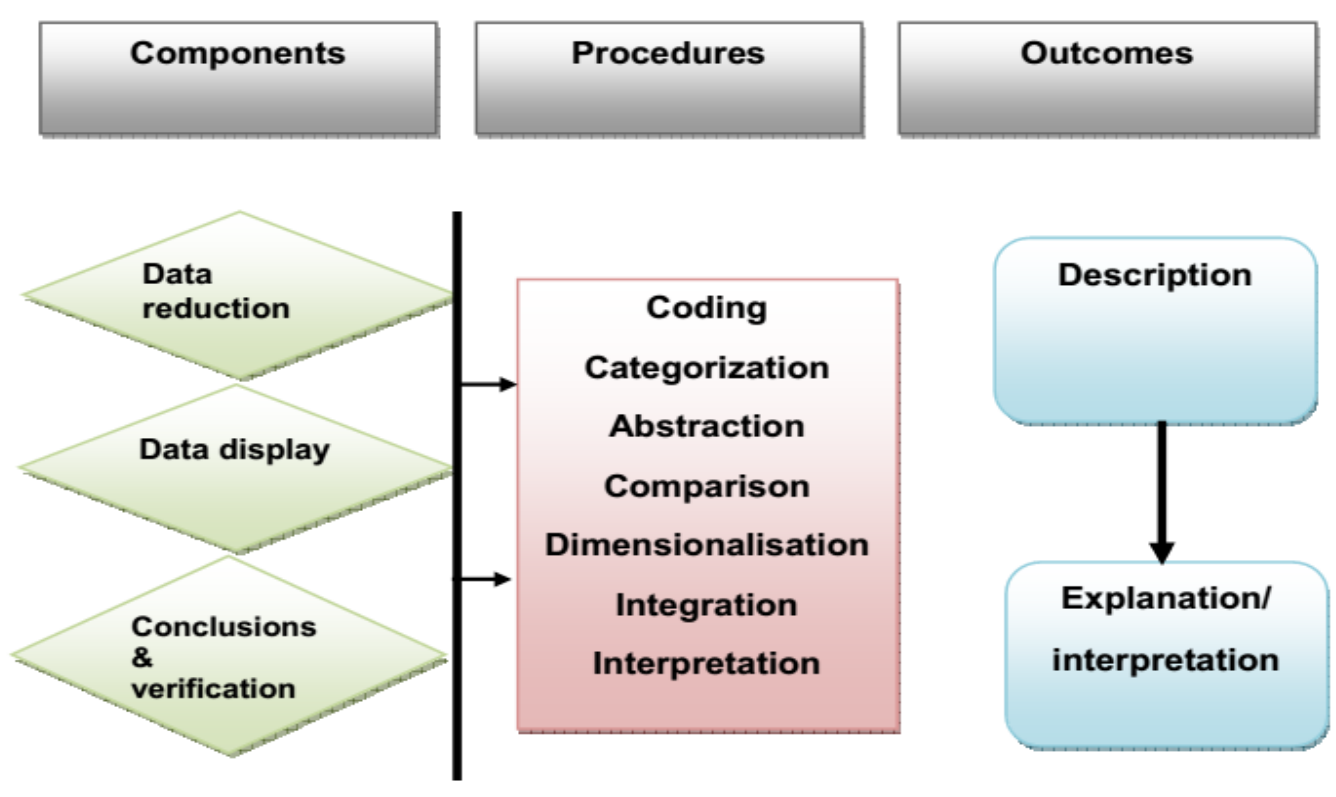

Source: Miles and Huberman, 1994.

Figure 3.1 Analysis process of qualitative data

First, it required to have a quick review on all these data, arrange them follow each village, then, do the first step of data analysis which is data reduction. According to Miles and Huberman (1994), "data reduction refers to the process of selecting, focusing, simplifying, abstracting, and transforming the data which appear in written up field notes or transcriptions". In this period, all field notes and audio record collected were first documented under the short report format. These short formats consists of general 
information, description of context of fieldwork, main content of the report and related raw data sources (Minh, 2009).

Second step of analyzing qualitative data is data display. In this period, text or diagram, chart and matrix were created to arrange fixed data, set up interrelationship from words form of data. Coding can be used to name different livelihood strategies and it facilitates respondent's ranking of these methods.

In the last step of qualitative data analysis, meaning of analyzed data was considered. According to Miles and Huberman (1994), in this period, works include "verification, integrally linked to conclusion drawing, entails revisiting the data as many times as necessary to cross-check or verify these emergent conclusions".

SWOT (strength, weakness, opportunity and threat) was used to identify the potentiality of each alternative livelihood.

- Strengths were used to identify possible advantages if local farmers change their livelihood activities from cardamom cultivation to another crop or activity. It includes natural condition, equipment, availability of input, production cost, availability of labor, skill, market,...

- Weaknesses: find out problems, disadvantages when local people change livelihood from cardamom cultivation to another crop/livestock or tourism engaged activities

- Opportunities refer to support from government, local government, projects in the region and possibility of expanding activity, possibility to enhance market or promote activities on large scale...

- Threats are something that prevents the establishment and development of new livelihood activity

\section{-Tools for data analysis}

Microsoft Office Excel and Statistical Program for Social Science (SPSS) were used as tool to analyze data. Results were presented using tables, graphs, figure, dendogram and matrix. 


\section{Chapter 4}

\section{Study area}

\subsection{Location of Hoang Lien national park}

Hoang Lien national park also called Hoang Lien mountain forest $\left(22^{\circ} 08^{\prime}-22^{\circ} 23^{\prime} \mathrm{N}\right.$, $103^{\circ} 46^{\prime}-104^{\circ} 00^{\prime}$ E) is located within Hoang Lien Son range which is the biggest mountain range in the North of Vietnam. It is situated in area of Lao Cai province and Lai Chau province in Northwest Vietnam (Nguyen Thi Hai et al., 2008).

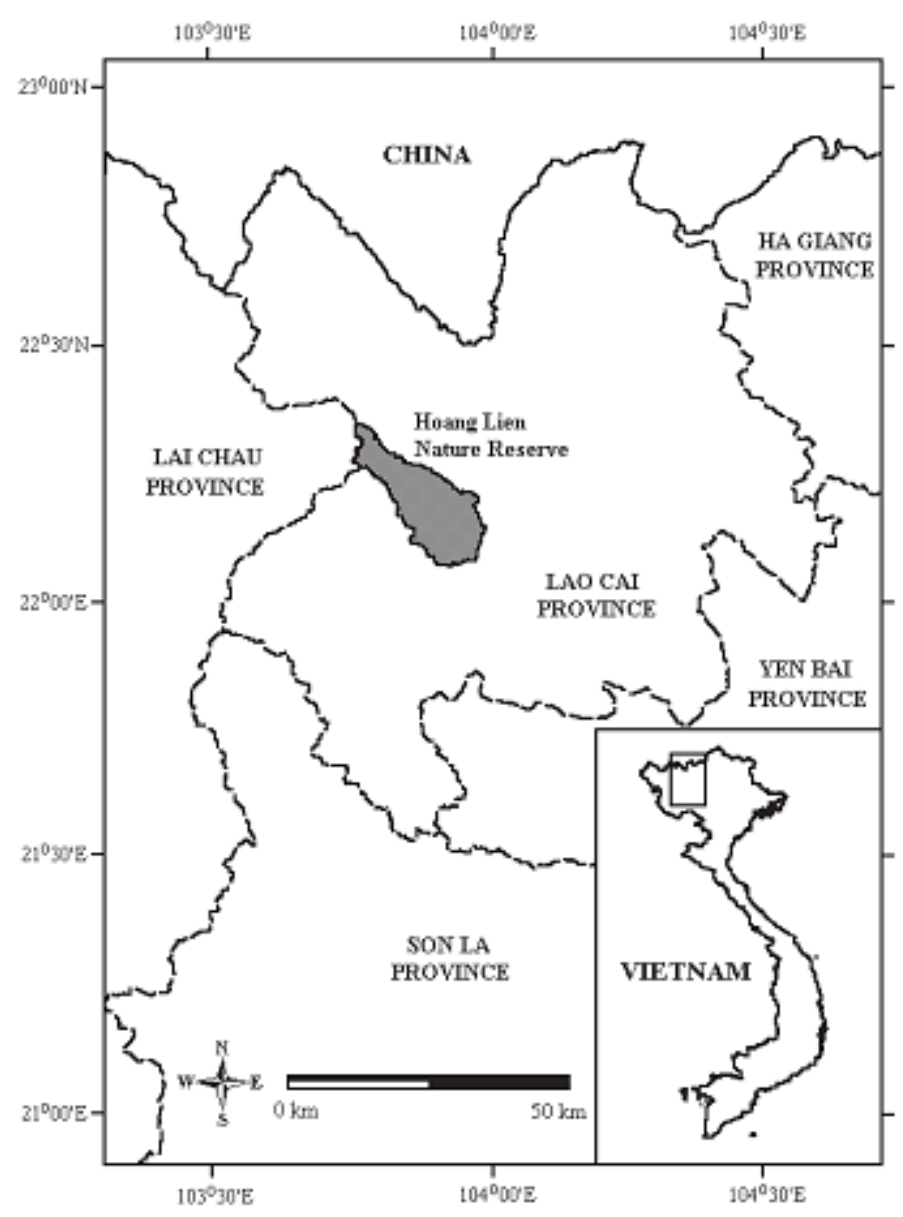

Figure 4.1: Location of Hoang Lien national park

The park currently covers an area of 28,476 hectares including a strict protection area of 11,875 hectares and a forest rehabilitation area of 16,601 hectares. This core area encompassed six communes: San Sa Ho, Lao Chai, Ta Van and Ban Ho in Sapa district and Muong Khoa commune, Than Thuoc commune of Than Uyen district. The buffer zone constitutes an area of 38,724 hectares which includes Sapa town and several communes belonging to Sapa district, Van Ban district of Lao Cai and two communes in Phong Tho, Lai Chau province (Frontier Vietnam, 1999).

Villages located near boundary of HLNP and easy to access include (1) O Quy Ho, (2) Sin Chai, (3) Cat Cat, (4) Y Linh Ho, (5) Lao Chai, (6) Ta Van, (7) Giang Ta Chai, (8) Ban Ho. Four villages Seo Mi Ty, Ta Trung Ho, Seo Trung Ho and Den Thang located deeply in the core zone of HLNP (Figure 3.2). 


\subsection{History of establishment and development}

Conservation of Hoang Lien mountain forest started since Hoang Lien Nature Reserve was established on 9th August 1986 according to the Decision No. 194/CT of the Chairman of the Council of Ministers with area of 5,000 hectares to protect "high-mountain forests, mono-Fokienia hodginsii stands and valuable medicinal herbs" (Cao Van Sung, 1995).

There was an investment plan in 1993 defined that the area of Hoang Lien Nature Reserve was expanded up to 29,845 hectares including six communes in Sapa and Than Uyen district. In 1994, the Hoang Lien Nature Reserve management board was established according to the Decision No. 39/QĐ-UB of Lao Cai povincial People Committee and it reported to Lao Cai Provincial Forest Protection Department (FPD). In 1997, the area of the nature reserve was reduced to 19,991 hectares because the part belonging to Than Uyen district was managed by the Song Da Watershed Protection Forest Management Board instead of nature reserve management board. In 1998, the boundary of the nature reserve was revised again to include areas in Ban Ho commune of Sapa district and the core area covered 24,658 hectares in total (Frontier Vietnam, 1999). However, due to limited infrastructure, and lack of officers with good knowledge and skills, management board of the nature reserve including only 14 members faced many challenges and difficulties in protection of 24,658 hectares mountain forest because there are 19 villages inside the nature reserve boundary, especially 5 villages: Seo My Ty, Den Thang, Ta Trung Ho, Seo Trung Ho, Ma Quai Ho situated deeply in the core zone (According to Website of HLNP).

Hoang Lien Nature Reserve was turned to Hoang Lien National park according to the Decision No. 90/2002/QĐ-TTg of the Prime Minister on 12nd July 2002. With regard to this Decision, the national park has total area of 29845 hectares comprising a strict protection area of 11,875 hectares, a forest rehabilitation area of 17,900 hectares and an administration-services area of 70 hectares. The Hoang Lien National park management board was established on 27th September 2002 according to the Decision 3274/2002/QĐUB of the Chairman of Lao Cai provincial People Committee. In 2003, Hoang Lien national park was recognized as ASEAN Heritage Park by the environmental ministers of ASEAN nations (BirdLife International in Indochina and MARD, 2004).

At present, Hoang Lien national park constitutes an area of 28,476 hectares including a strict protection area of 11,875 hectares, a forest rehabilitation area of 16,601 hectares. In addition, the buffer zone has area of 38,724 hectares as mentioned in previous section. Infrastructure and management board of the national park have been improved significantly thanks to attention of government and investment from national as well as international organizations.

\subsection{Topography, hydrology and climatic conditions}

Situated in the northeast flank of Hoang Lien Son range which is the southeastern extension of the Himalayan from Yunnan in China to the North of Vietnam, Hoang Lien national park is in elevation mostly ranging from 1,000 to $3,000 \mathrm{~m}$ above sea level. It includes the highest peak of Vietnam called Fansipan or "The roof of Indochina" with an elevation of 3,143 m above sea level. The lowest point of the park is $380 \mathrm{~m}$. Sapa town the capital in the region locates at elevation of 1,650 m (Frontier Vietnam, 1999).

In general, the national park has complex and diverse relief. Average slope ranges from 25 degree to 35 degree and reach to 40 degree - 50 degree in some area (Nguyen Thi Hai et 
al., 2008). It is steep and difficult to access on foot in high mountains. However, there are several fertile valleys at the foot of mountains which has been densely populated by ethnic groups and terraced for rice cultivation such as those located in Ta Van, Lao Chai and Ban Ho communes or Muong Hoa valley located between Fansipan Mount and Sapa town.

With regard to hydrology, Muong Hoa river drains the northern area of the national park and flows into Red River while Ta Trung Ho river drains the southern part of the national park and flows into Nam Po and Nam Cang stream and finally contribute to Black River (Kemp et al., 1995). Besides these two rivers, there is a dense system of numerous narrow and deep streams. Hoang Lien forest plays an important role in catchment protection. At present, this national park is among 4 protected areas in watershed of the Da River which provide reservoir with water and ensure operations of Hoa Binh hydropower dam and Son La hydropower dam at downstream (ICEM, 2003).

Hoang Lien national park has seasonal climate characterized by "subtropical climate in summer" and "temperate climate in winter" (Kemp et al., 1995). In brief, the weather is cool in the whole year. As reported in Sapa town, the annual temperature ranges from $1{ }^{\circ} \mathrm{C}$ to $29.4^{\circ} \mathrm{C}$ and the mean annual temperature is $15.4^{\circ} \mathrm{C}$ (Ghazoul \& Le Mong Chan, 1994). The weather is warmest in July, August and coldest in December and January. Sometimes, it has snow falls in some highest mountain.

Similar to other Northern provinces, there is a 5-month rainy season from May to September with mean annual of $2,763 \mathrm{~mm}$. Rainfall in the national park is often higher than $2000 \mathrm{~mm}$, even up to $4000 \mathrm{~mm}$ especially in July and August when heavy rain occurs often. The region has high humidity represented by the humidity range from $75 \%$ to $91 \%$. Due to wind direction from west to east year around, there is cloud formation on upper slopes of Fansipan mountain range. Therefore, areas at high altitude are always covered by cloud and extremely humid (Frontier Vietnam, 1999).

\subsection{Biodiversity values}

Since its establishment to now, forest vegetation types in the HLNP was studied by the Institute of Ecology and Biological Resources in 1998; the Forest Planning Institute in 2002. Due to the effects of social economic of ethnic village located in both the core zone and the buffer zone of HLNP including cardamom cultivation under the forest canopy and timber illegal extraction, the plant diversity of HLNP has reduced. The recent investigation conducted by HLNP management board in 2003 gave results that there are 2343 species in HLNP belonging to 1020 genera and 256 families (Table 4.1).

Among 2343 species, 34 species were listed in the Red List (IUCN 1998), 82 species were listed in the Vietnam Red Book (1996) and 11 species were listed at risk of extinction in Decree 18 and Decree 48. With regard to use, 754 species being classified as medicinal plants; 458 species being classified as standing timber; 311 species are considered as shade and ornamental trees; 126 species are enumerated as vegetables; 60 species are taken for fruit, 43 species are taken for latex, 35 species are taken for tannins, 41 oil species, 26 species is used for oleoresins wax, 25 species are classified as knit material, 23 species can be used for fiber string, 21 species for green manure, 17 species for tuber, 10 species for roof houses, 10 species for dye and 9 species for starch (Hoang Van Tu, 2012). 
Table 4.1: Flora species in Hoang Lien National Park

\begin{tabular}{|r|l|l|r|r|r|}
\hline No. & Phylum & Scientific name & Species & Genera & Family \\
\hline 1 & Pine needle & Psilotophyta & 1 & 1 & 1 \\
\hline 2 & Pine & Lycopodiophyta & 8 & 4 & 2 \\
\hline 3 & Equisentum & Equisetophyla & 1 & 1 & 1 \\
\hline 4 & Fern & Polypodiophyta & 257 & 94 & 32 \\
\hline 5 & Gymnosperm & Gymnospermae & 20 & 14 & 7 \\
\hline 6 & Angiosperm & Angiospermae & 2056 & 906 & 213 \\
\hline 7 & Monocotyledon & Monocotyledoneae & 372 & 176 & 36 \\
\hline 8 & Dicotyledon & Dicotyledoneae & 1687 & 730 & 176 \\
\hline & Total & & 2343 & 1020 & 256 \\
\hline
\end{tabular}

Source: Data for additional investigation of the Hoang Lien vegetation forest, 2003.

With regard to fauna, there were 555 species of vertebrates in HLNP including: 96 species of mammals, 346 species of birds, 63 species of reptiles, 50 species of amphibians (Table 4.2). Among those 555 vertebrate species, there were 60 rare animal species listed in the Vietnam Red Book (1992) and 33 species listed in IUCN/1996 Red Book (Hoang Van Tu, 2012). Animals were listed in category of endangered species include black gibbon Northeast (Nomasscus concolar), hornbill (Buceros bicornis), Musk-deer (Tragulus javanicus), Langur (Trachypithecus). Reptiles, amphibians have commercial value or medicinal such as turtle, varan and snakes also belong to threatened category.

Table 4.2: Vertebrates species in Hoang Lien National Park

\begin{tabular}{|c|l|c|c|}
\hline No. & Taxon & Families & Species \\
\hline 1 & Mammals & 27 & 96 \\
\hline 2 & Birds & 52 & 346 \\
\hline 3 & Reptiles & 9 & 63 \\
\hline 4 & Amphibians & 7 & 50 \\
\hline & Total & 95 & 555 \\
\hline
\end{tabular}

Source: Data for additional investigation of the Hoang Lien's fauna, 2003

\subsection{Social-economic conditions}

Local people living in HLNP (both core zone and buffer zone) belongs to six ethnic minority groups which are H'mong, Tay, Dao, Giay, Kho Mu and Kinh people (Frontier Vietnam, 1999). Among these groups, H'mong ethnic minority has highest population accounted for $37.6 \%$ and inhabit in all six communes of HLNP. The second largest group is Tay ethnic group accounted for $36.4 \%$ and they inhabit mainly in Tan Uyen district, Lai Chau province and it is followed by Dao ethnic group with $6.5 \%$ of total population (Hoang Van Tu, 2012). H'mong ethnic group primarily lives in high mountains which are above $1000 \mathrm{~m}$. They concentrate at the northern end of Muong Hoa valley, below the Fanxipan mount, and in villages deeply resided in Hoang Lien forest. In contrast, Dao and Tay ethnic group always reside at areas lower than $1000 \mathrm{~m}$ such as in the southeast of HLNP. Giay ethnic group stay in Ta Van commune. 
Inside the core zone of the HLNP, there are three main ethnic minority groups which are Black H'mong, Red Dao and Giay ethnic group with the corresponding proportion of $73.8 \%, 17.4 \%$ and $8.8 \%$. Among five villages located in the core zone of HLNP, Red Dao stay in Ta Trung Ho village and Seo Trung Ho village while Black H'mong people live in three other villages called Seo My Ty, Ma Quai Ho and Den Thang. Due to the deep location in the core zone, these local inhabitants face many difficulties in transportation, walking, access market. Education, health care services are also limited in these villages.

At present, there are 24006 people living in buffer zone and core zone of HLNP corresponding to 4362 households distributed in 39 villages (Table 4.3). It is easily to calculate that the number of household member is in range from 5 to 6 people/ household. The people density has large range represented by the lowest density of 22 people $/ \mathrm{km} 2$ in Ta Van commune and the highest density of 118 people/km2 in San Sa Ho commune which is double the average density of the whole HLNP which is 58 people $/ \mathrm{km} 2$. Phuc Khoa district and Trung Dong district have same people density which is much higher compared to the average people density of the national park.

Table 4.3: Current status of the ethnicity, population and labor of communes in HLNP

\begin{tabular}{|l|l|c|c|c|c|l|l|}
\hline $\begin{array}{l}\text { District, } \\
\text { province }\end{array}$ & Commune & No. of hhs & $\begin{array}{l}\text { No. of } \\
\text { people }\end{array}$ & $\begin{array}{l}\text { No. of } \\
\text { labor }\end{array}$ & \% labor & Ethnicity & $\begin{array}{l}\text { Density } \\
\text { (people/km2) }\end{array}$ \\
\hline $\begin{array}{l}\text { Sapa, } \\
\text { Lao Cai }\end{array}$ & San Sa Ho & 607 & 3792 & 1904 & $50 \%$ & H'mong & 118 \\
\cline { 2 - 8 } & Lao Chai & 574 & 3464 & 1605 & $46 \%$ & H'Mong & 54 \\
\cline { 2 - 8 } & Ta Van & 658 & 3657 & 1877 & $51 \%$ & $\begin{array}{l}\text { Giay, Dao, } \\
\text { H'mong }\end{array}$ & 22 \\
\cline { 2 - 8 } & Ban Ho & 482 & 2546 & 1287 & $50 \%$ & $\begin{array}{l}\text { Tay, Dao, } \\
\text { H'mong }\end{array}$ & 92 \\
\hline $\begin{array}{l}\text { Tan Uyen, } \\
\text { Lai Chau }\end{array}$ & Phuc Khoa & 978 & 4472 & 2195 & $49 \%$ & $\begin{array}{l}\text { Kinh, Tay, } \\
\text { H'mong }\end{array}$ & 92 \\
\cline { 2 - 8 } & Trung Dong & 1063 & 5805 & 2391 & $41 \%$ & Tay, H'mong & 58 \\
\hline \multirow{2}{*}{ Total } & 6 communes & 4362 & 24006 & 11259 & $47 \%$ & & 58 \\
\hline
\end{tabular}

Source: Committee of commune and district statistical office, 2011.

In all communes, the labor accounts for more than $40 \%$ of the total population and reach the highest proportion of $51 \%$ in Ta Van commune, Sapa district. Over all, there are $47 \%$ of people living in HLNP in working age (Table 4.3)

With regard to livelihood, economic activity of local residents in HLNP is agriculture. Some communes do slash and burn whereas H'mong reside near Sapa do permanent agriculture with terraced wet rice fields on mountainous land (Donovan et al, 1997). This system is evaluated as a sustainable agriculture (Pham, 1995). Crops planted in HLNP include paddy rice in terraced fields, maize and cassava on hillside and cardamom under forest canopy. Two Dao ethnic minority villages (Ta Trung Ho and Seo Trung Ho) plant cassava whereas other villages grow maize for feeding both people and animal. Besides these main crops, local people also grow potato, bean, hemp, arrowroot, peanuts and bamboo and used mainly for home consumption. With cool weather all year round, local 
households in HLNP always grow plum tree and gourds, pumpkin in the garden. Tay ethnic group stay in Ban Ho village has papaya, banana and lotus in their home garden. With regard to livestock, almost households raise chickens, pigs, goats for home consumption and own buffaloes and horses to have draught power and transportation. They are eaten at festivals, weddings and New Year holiday. In addition, household can use these livestock as a source of income when they need money (Frontier, 1999).

Beside agriculture production, local people cut timber for house construction, making furniture and agricultural tools; collect firewood for cooking and heating, collect NTFPs such as young bamboo shoots, edible roots and leaves, mushrooms, honey, medical plants, ornamental plants, animals for both home consumption and sale (Frontier Vietnam, 1999).

It is estimated that ethnic minority groups in Northern Upland of Vietnam have highest incidence of poverty (Minot et al., 2006). The fact that local people engage in tourism is a good strategy to improve livelihood assets in term of financial, social and human capital. In recent years, Vietnam government and non-governmental organization such as Oxfam, CARE,.. have organized developmental programs in Lao cai provinces in general and in Sapa in particular. Foreign language classes and cooking classes were open free for young people to facilitate these ethnic groups in tourism activities.

\subsection{Communes and Villages selected}

Within the boundary of Hoang Lien national park (in the part belonging to Sapa district of Lao Cai province), six villages in three communes were selected to conduct PRA on history of village, farming system, crop history, crop season and potential products in each village and adjacent area. Among those six villages, four villages were selected to conduct household survey in order to collect data on household characteristics, farming system and generating cash-income activities of local people, local knowledge about forest protection and diversity conservation... Those four villages were selected based on the difference of crops grown, the diversity of livelihood activities, different zone of the national park, different ethnic groups and different market access. Selected villages were located between 1200 and $2000 \mathrm{~m}$ a.s.l. The number of households in each village is approximately 100 households. Ethnicity is different including H'mong and Dao who live on high elevation, Tay and Giay who live on intermediate elevations.

In San Sa Ho commune, Cat Cat village and Sin Chai village were chosen for its close to Sapa town of $2 \mathrm{~km}$ and the difference in characteristics of livelihood strategies of villagers. Local people in both villages belong to Black H'mong ethnic group. Sin Chai village has high number of poor households and highly depends on cardamom cultivation for cash income generation whereas Cat Cat villagers has participated in tourism based activities such as selling handicraft and hire trekking for foreign visitors. Because this study focused on cardamom cultivation, Sin Chai village was chosen for conducting the household survey. 
Table 4.4: Location of 6 selected villages in part of HLNP belonging to Lao Cai province

\begin{tabular}{|l|l|l|l|c|c|c|}
\hline Commune & $\begin{array}{l}\text { Distance to Sapa } \\
\text { town }(\mathrm{km})\end{array}$ & $\begin{array}{l}\text { Village } \\
\text { (PRA) }\end{array}$ & $\begin{array}{l}\text { Main ethnic } \\
\text { group }\end{array}$ & $\begin{array}{l}\text { No. of } \\
\text { hhs }\end{array}$ & $\begin{array}{l}\text { No. of } \\
\text { poor hhs }\end{array}$ & $\begin{array}{c}\text { Zone of } \\
\text { HLNP }\end{array}$ \\
\hline \multirow{2}{*}{ San Sa Ho } & 2 & Cat Cat & Black H'mong & 109 & - & Buffer zone \\
\cline { 2 - 7 } & 6 & Sin Chai $*$ & Black H'mong & 225 & - & Buffer zone \\
\hline \multirow{2}{*}{ Ta Van } & 8 & Ta Van Giay1* & $\begin{array}{l}\text { Giay, } \\
\text { Black H'mong }\end{array}$ & 125 & 26 & Buffer zone \\
\cline { 2 - 7 } & 20 & Seo My Ty* & Black H'mong & 85 & 39 & Core zone \\
\hline \multirow{2}{*}{ Ban Ho } & 25 & La Ve & Tay & 94 & 52 & Buffer zone \\
\cline { 2 - 7 } & 34 & Ta Trung Ho* & Red Dao & 96 & 18 & Core zone \\
\hline
\end{tabular}

Source: Field survey, 2013.

* Villages where household survey was conducted

- Data not available

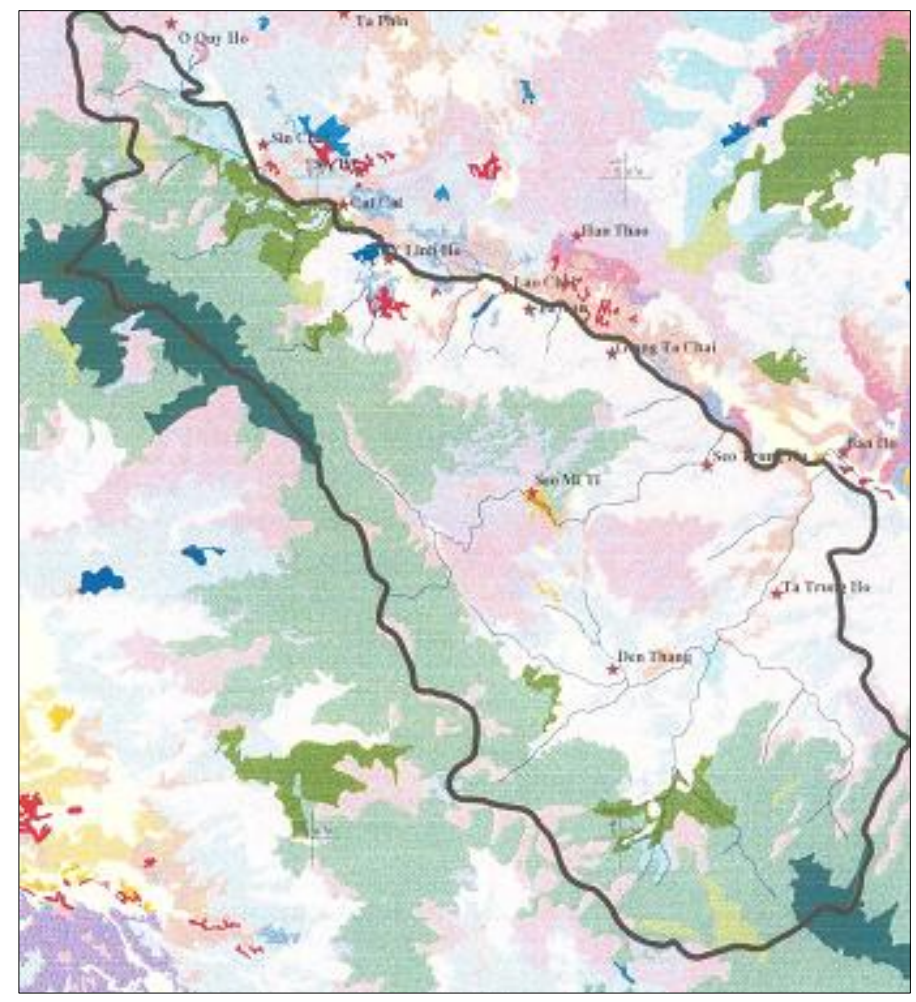

Figure 4.2 Six villages selected of which four villages selected for hh survey

In Ta Van commune, Ta Van Giay 1 was selected for the diversity in livelihood strategies including agricultural production for both self-sufficiency and market along with homestay services for visitors. It is located in the buffer zone of the Hoang Lien national park which is $8 \mathrm{~km}$ far from Sapa town and ethnicity includes $75 \%$ Giay ethnic group and the rest Black H'mong ethnic group. In contrast, in Seo My Ty village located in the core zone of the national park at elevation of 1600 meters a.s.l which is $12 \mathrm{~km}$ far from the Ta Van communal people committee and 20km far from Sapa town, 99\% household is Black H'mong ethnic group. Construction of one reservoir of Seo Trung Ho hydro power in Seo My Ty village has led to the loss of almost flat paddy field. The local people must purchase land in other adjacent villages to cultivate rice for self-sufficiency. It cause difficulties as well as increase transportation cost in production because of long distance to the field. 
Cash income of H'mong community in Seo My Ty village is mostly from cultivation of cardamom under the forest canopy.

In Ban Ho commune which is $25 \mathrm{~km}$ far from Sapa town, La Ve village locates in the buffer zone of Hoang Lien national park and villagers belong to ethnic group Tay. It is the center of Ban Ho commune. They have home-stay service for tourists in addition to agricultural production, however, the number of visitors reduced recently due to the loss of natural environment after the construction of Su Pan 2 hydro power plant. The second village selected was Ta Trung Ho village which locates in the core zone of Hoang Lien national park which is $10 \mathrm{~km}$ far from the Ban Ho communal people committee and $35 \mathrm{~km}$ far from the town. The local people belong to the ethnic minority Red Dao. They have large agricultural land area and produce enough stable crops for home consumption while cash income is obtained primarily from cardamom plant.

\subsection{Upland landscapes (transect)}

Although selected villages locate in different agro-ecological zones and altitudes, almost households have similar structure of land use including river, fish pond and paddy field in the form of terrace; houses with home garden on foothill; terrace for rice cultivation where water available; cash crops such as maize (in Ban Ho commune, cassava is planted) and forest on hill tops and evergreen forest with cardamom cultivation under the shade.

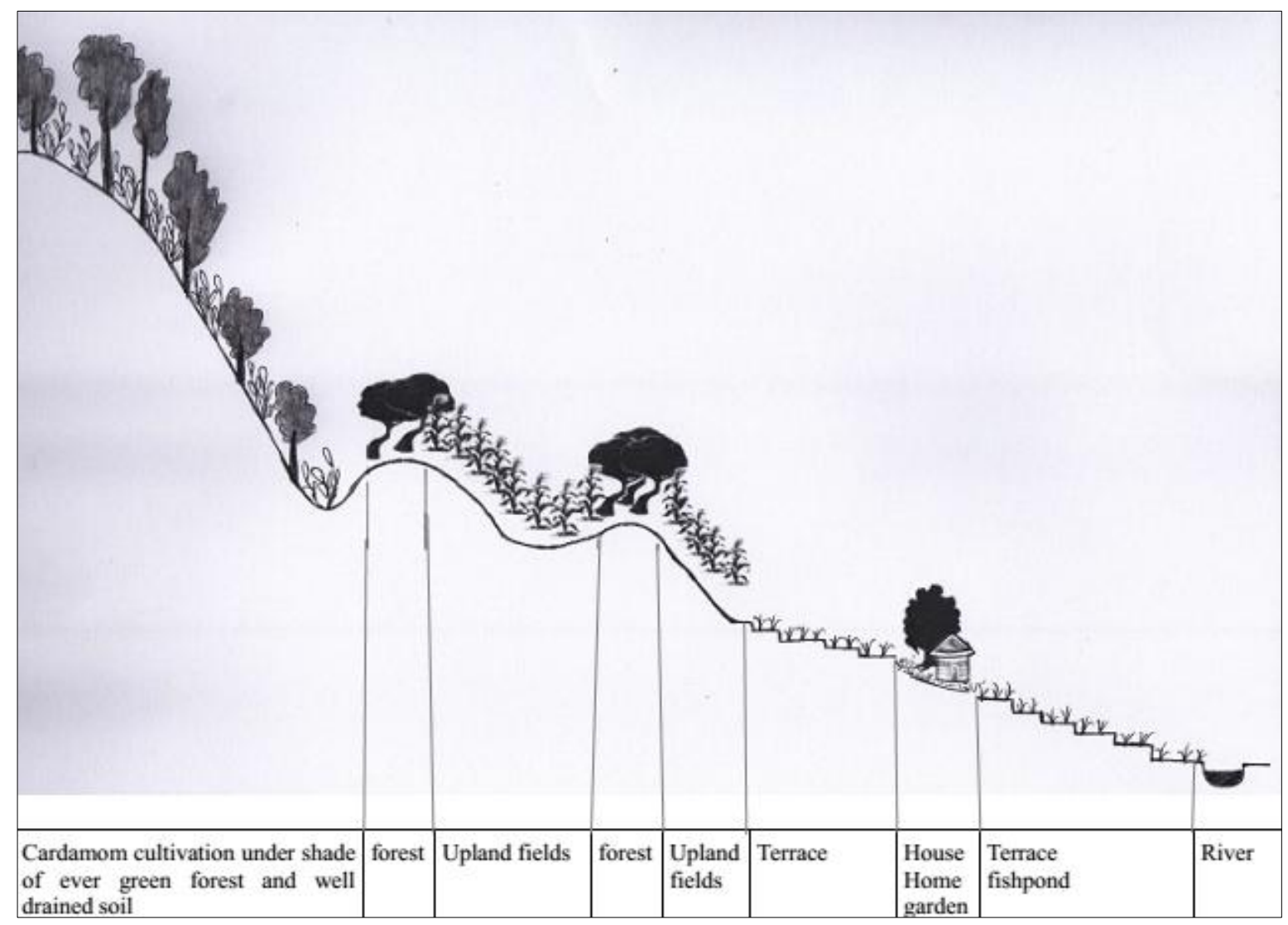

Figure 4.3 Upland transect and different agro-ecological zones in HLNP

In HLNP, two rivers which are Muong Hoa River and Ta Trung Ho River along with a dense system of numerous narrow and deep streams provide water for local people to cultivate paddy rice on terrace land. 
The second agro-ecological zone - terrace is the typical irrigated lowland in Sapa district, Lao Cai province where HLNP locates. Due to limited access to water, most of local people cultivate one paddy rice crop season per year. A small number of households cultivate two crop seasons per year, however, the crop yield is reduced.

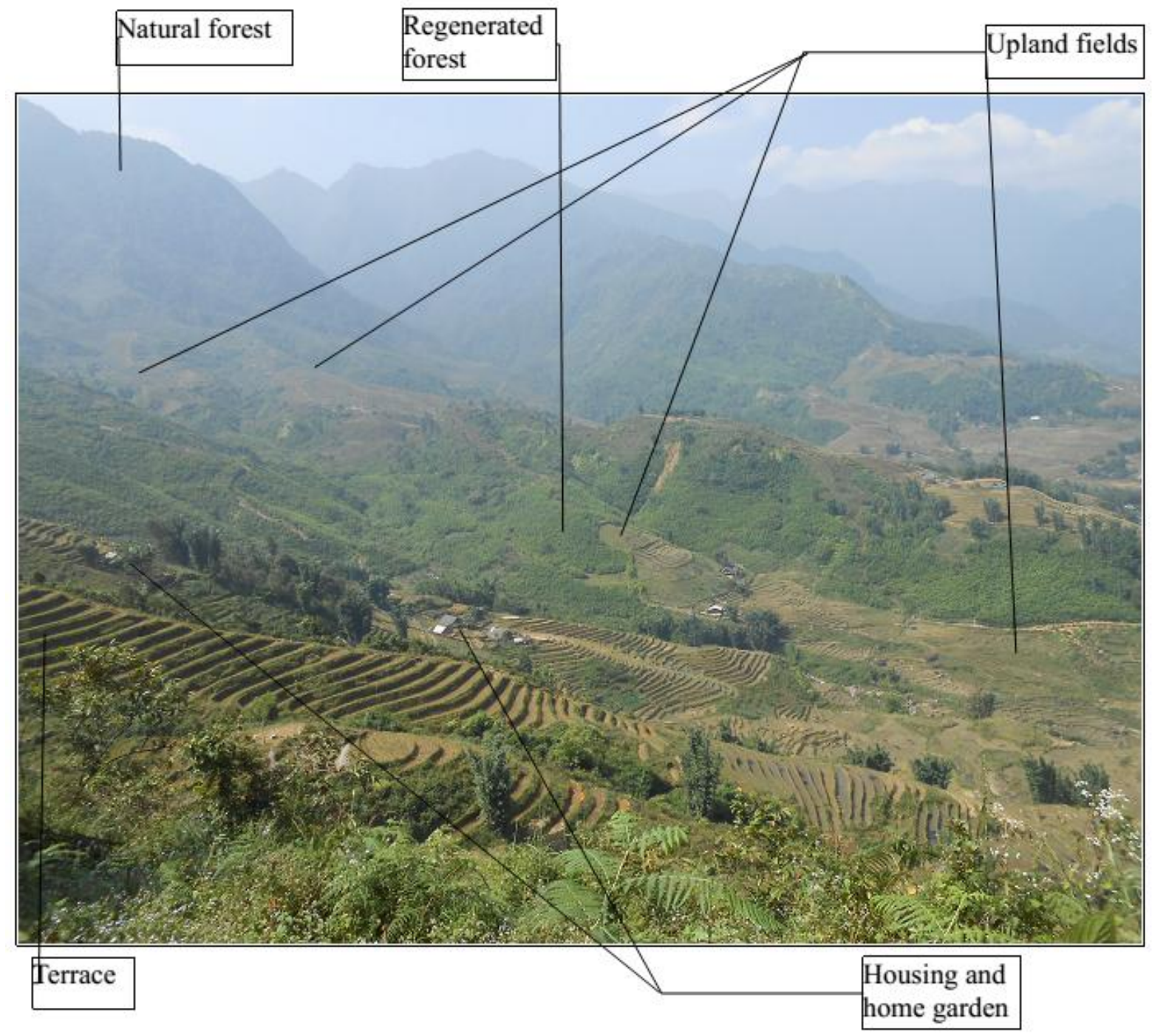

Figure 4.4 Agro-ecological zone in HLNP (own photo)

The third agro-ecological zone is residential land and home garden where local people grow vegetables, spices, fruit tree as well as raising livestock around their wooden houses. Terrace is the next agro-ecological zone and it is followed by upland field. Local people created terrace where water sources are available and grow paddy rice. On the contrary, where water sources are not available, crops which do not require much water such as maize, cassava are planted. These dry fields could be called upland field or sloping land. Tradition of shifting cultivation of ethnic minority groups in mountainous area of Vietnam has led to significant change in land cover and land use from forest covered areas to barren hill, upland fields. Increase in population led to increase in residential area and cultivated area, thus, each household expand their cultivated area by clearing forest near by their upland field and creating more terrace (Figure 4.3). Forest is kept on hill top to protect soil and prevent soil erosion. . To avoid the damage of crops, big livestock such as buffalo, cow and goat are released in terrace and upland fields before planting crops and after harvest season. In other periods, big livestock are released in regenerated forest around upland fields. 
The last agro-ecological zone is natural forest where local people (especially H'mong and Dao ethnic minority group who always stay at high elevation) plant cardamom under forest canopy. This type of forest farming bring cash income for local people, therefore, the cardamom cultivated area is expanded throughout HLNP where forest quality and water access are good, even the area near Panxipan peak.

The model of paddy - home garden - upland fields - forest is very popular in mountainous areas of Vietnam as local people have taken the best use of water sources in valleys for rice production and cut down forest on sloping land for shifting cultivation for a long time. On upland fields, crops with low water requirement such as upland rice, maize and cassava are always grown. A part of natural forest are kept on top of the hill to protect the soil, however, some farmers clear forest on top of low hills for agricultural production. 


\section{Chapter 5}

\section{Respondents and household characteristics}

\subsection{Characteristics of respondents}

Respondents from the sampled households were household heads who have good knowledge about social-economic activities of the household as well as responsibility in decision-making. In case the household head is too old for answer the questions, his/her son who knows information support his/her to answer the question. However, this situation occurs only in a few households.

\subsubsection{Gender}

The sex ratio in four villages surveyed was 0.99 (Table 5.1), meaning that the female population was smaller than the male population. The buffer zone has higher sex ratio than the core zone demonstrated by 101 female: 100 male and 97 female: 100 male.

Table 5.1: Demographic characteristics of households sampled

\begin{tabular}{|l|c|c|c|c|c|c|}
\hline Village & $\begin{array}{l}\text { No. of hhs } \\
\text { sampled }\end{array}$ & $\begin{array}{l}\text { No. of female } \\
\text { headed hh }\end{array}$ & $\begin{array}{l}\text { Total hh } \\
\text { member }\end{array}$ & $\begin{array}{l}\text { No. of male } \\
\text { member }\end{array}$ & $\begin{array}{l}\text { No. of female } \\
\text { member }\end{array}$ & $\begin{array}{l}\text { Sex ratio } \\
\text { (F/M) }\end{array}$ \\
\hline Seo My Ty & 15 & 0 & 110 & 55 & 55 & 1 \\
\hline Ta Trung Ho & 15 & 0 & 93 & 48 & 45 & 0.94 \\
\hline Sin Chai & 15 & 3 & 84 & 41 & 43 & 1.05 \\
Ta Van Giay1 & 15 & 1 & 83 & 42 & 41 & 0.97 \\
\hline Core zone & 30 & 0 & 203 & 103 & 100 & 0.97 \\
\hline Buffer zone & 30 & 4 & 167 & 83 & 84 & 1.01 \\
\hline Total & 60 & 4 & 370 & 186 & 184 & 0.99 \\
\hline
\end{tabular}

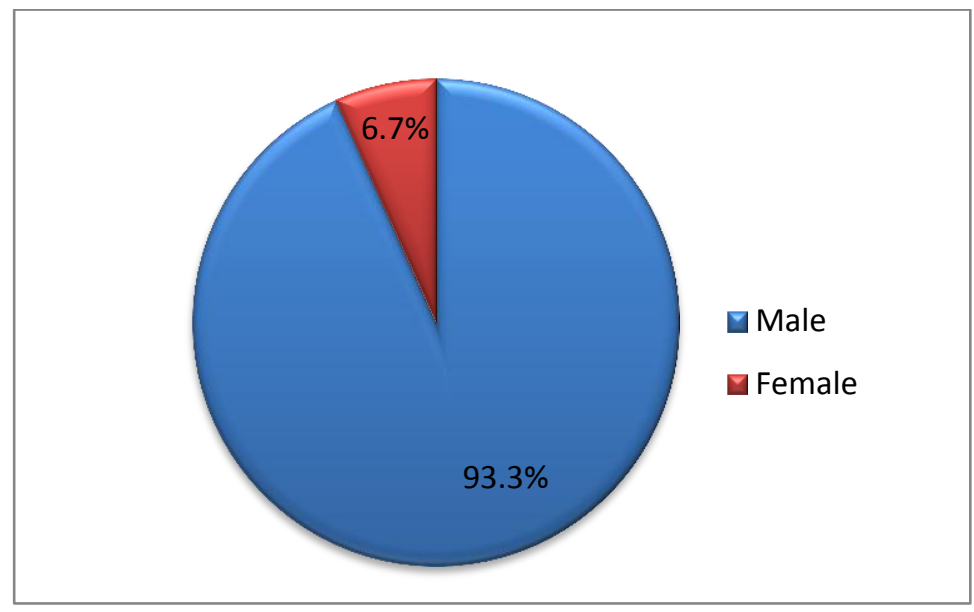

Figure 5.1: Distribution of respondents by gender

In the whole samples, there was no female-headed household in the core zone but it was four in the buffer zone. Overall, female respondents accounted for 6.7 percent of the total respondents; remaining 93.3 percent was male respondent. 


\subsubsection{Age groups}

The age of respondent were classified into two categories which are working age (from 15 to 59 years) and elderly age (equal and higher than 60 years old). To the whole samples, respondents were in range from 23 years old to 69 years old. $95 \%$ of the total respondents were in working age and 5\% remaining were in elder age. The average age was 40 years old (Table 5.2).

With regard to the difference between two zones of HLNP, there was no respondent at elderly age in the core zone whereas it existed at $10 \%$ in the buffer zone. Age range of respondent in core zone and buffer zone were from 23 to 59 years old and from 24 to 69 years old respectively. An independent-samples t-test was conducted to compare respondents' age in two zones. There was no significant difference in age of respondents in the core zone $(\mathrm{M}=39, \mathrm{SD}=10.34)$ and in the buffer zone $(\mathrm{M}=41.37, \mathrm{SD}=11.31)$; $\mathrm{t}(58)=$ $0.846, \mathrm{p}=0.401$.

Table 5.2: Distribution of respondents by age group

\begin{tabular}{|l|c|c|c|c|c|c|c|}
\hline \multicolumn{1}{|c|}{ Zone } & $\begin{array}{c}\text { \% working age } \\
15 \text { to } 59 \text { years }\end{array}$ & $\begin{array}{c}\% \text { elderly age } \\
>=60 \text { years old }\end{array}$ & $\begin{array}{c}\text { Minimum } \\
\text { age }\end{array}$ & $\begin{array}{c}\text { Maximum } \\
\text { age }\end{array}$ & $\begin{array}{c}\text { Average } \\
\text { age }\end{array}$ & SD & Diff. \\
\hline Core zone & 100 & 0 & 23 & 59 & 39.00 & 10.34 & \\
\hline Buffer zone & 90 & 10 & 24 & 69 & 41.37 & 11.31 & n.s. \\
\hline Total & 95 & 5 & 23 & 69 & 40.18 & 10.81 & \\
\hline
\end{tabular}

Independent-samples t test, $5 \%$ level of error probability

\subsubsection{Education}

In term of formal education, respondents had three years attended school in average, corresponding to several first years of elementary school (Table 5.3). Respondents in the buffer zone had one year longer time of formal education than respondents in the core zone. Independent samples t-test was applied to compare length of attending school of respondents in two zones of HLNP and it showed no statistically different as the last result $(\mathrm{t}(58)=1.090, \mathrm{p}=0.280)$.

Table 5.3: Number of years attended school of respondents

\begin{tabular}{|c|l|l|c|c|}
\hline Number of years attended school & Core zone & Buffer zone & Diff. & Total \\
\hline Mean (SD) & $2.63(3.60)$ & $3.60(3.25)$ & \multirow{2}{*}{ n.s. } & $3.12(3.44)$ \\
\cline { 1 - 3 } Minimum-Maximum & $0-12$ & $0-10$ & & $0-12$ \\
\hline
\end{tabular}

Independent-samples $t$ test, 5\% level of error probability

The highest education of respondents was upper secondary school corresponding to 10 years to 12 years education of Vietnam education system; however, only $3.33 \%$ of total respondents in each zone of HLNP reached that education level corresponding to $5 \%$ of total respondents. There was not any respondent obtained an education up to vocational school or undergraduate level. Respondents in the buffer zone had better education level than those in the core zone represented by lower percentage of illiterate respondents, higher percentage of respondents who obtained elementary education level and secondary education level. The proportion of illiterate among respondents was quite high. About $57 \%$ 
of household heads in the core zone and $37 \%$ of household heads in the buffer zone had no formal education. Overall, about $47 \%$ of total respondents were illiterate.

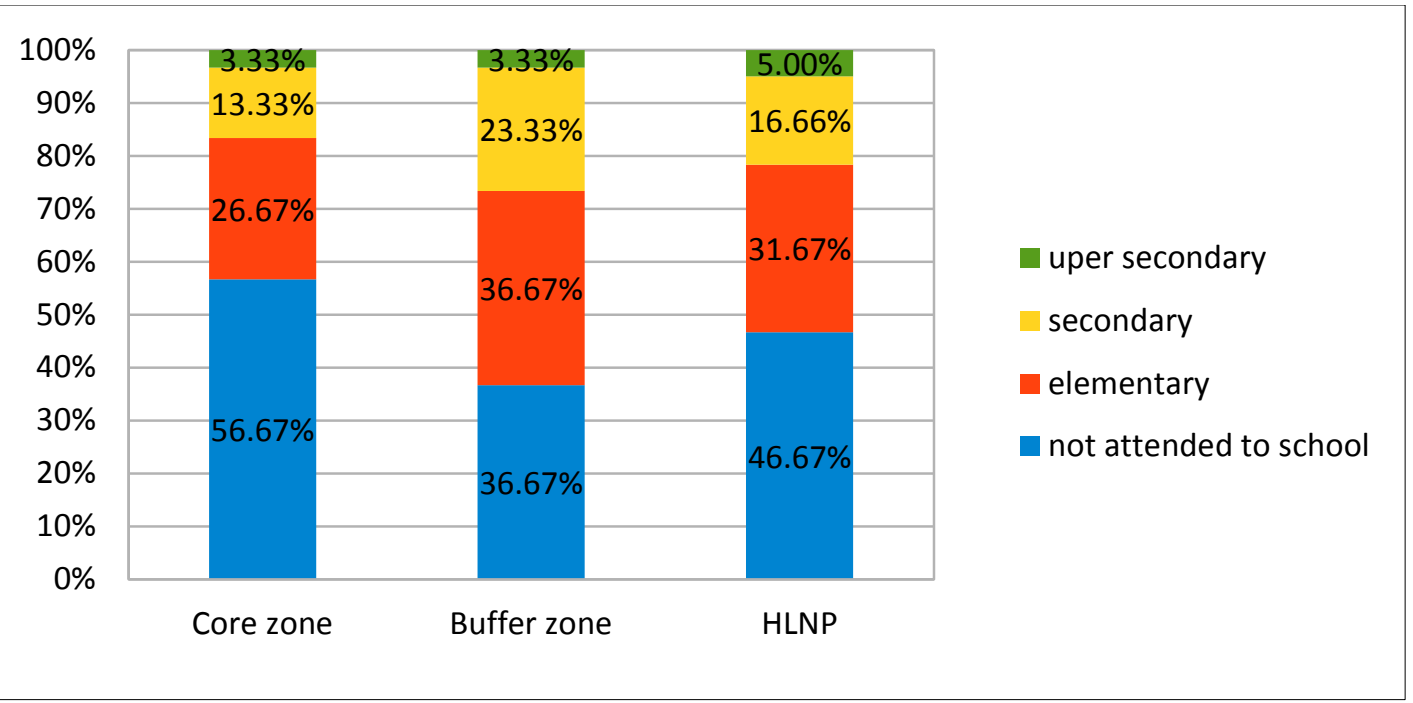

Figure 5.2 Distribution of respondents by education

\subsubsection{Ethnicity}

In the core zone of HLNP which is far from the communal road (the road connects the District People Committee in Sapa town to each commune of Sapa district) and difficult to access, there were 50\% Red Dao households (100\% respondents from Ta Trung Ho village), 46.7\% Black H'mong households (households in Seo My Ty village). 3.3\% Giay respondent represented for one Giay household which migrated from Ta Van Giay village to Seo My Ty village. In contrast, in the buffer zone, Black H'mong ethnic group was predominant represented by $63.3 \%$ of total respondents because villagers of both two selected villages in the buffer zone were Black H'mong ethnic people. $36.7 \%$ respondents left belong to Giay ethnic group who stayed in Ta Van Giay 1 village (Figure 5.3).

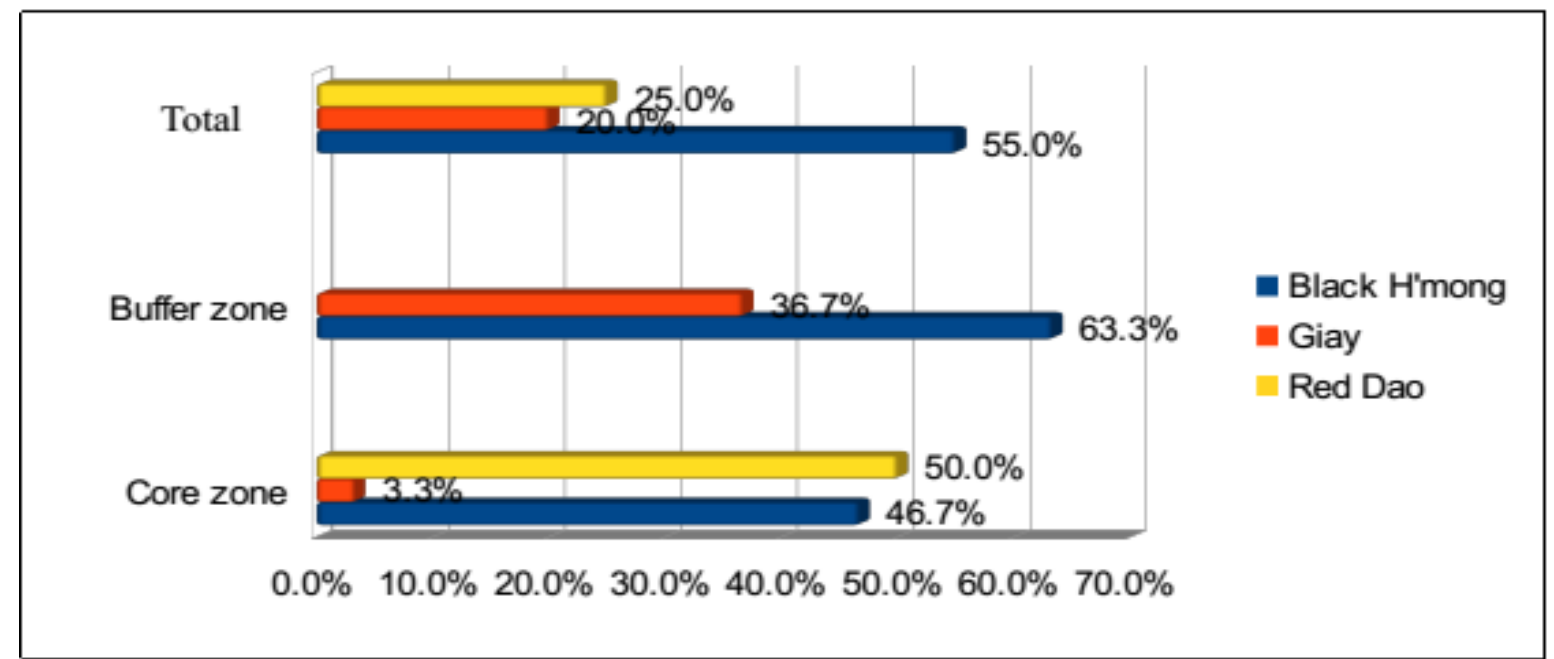

Figure 5.3: Distribution of respondents by ethnicity

Over all, in HLNP, the Black H'mong was the dominant ethnic group accounted for $55 \%$ of total respondents, and it was followed by Red Dao ethnic group and Giay ethnic group corresponding to $25 \%$ and $20 \%$ respectively. 


\subsubsection{Occupation structure}

Farming which refers to agricultural production and/or forest farming under shade of ever green forest was the dominant occupation of respondents because $93.3 \%$ of respondents did farming (Table 5.4). 3.33\% of respondent worked as carpenter and construction worker, another $3.33 \%$ wre forest resource extractors and only $1.67 \%$ of respondent worked as government officer.

Table 5.4: Distribution of respondents by main occupation

\begin{tabular}{|l|l|l|l|l|l|l|}
\hline \multirow{2}{*}{ Main occupation } & \multicolumn{2}{|c|}{ Core zone } & \multicolumn{2}{c|}{ Buffer zone } & \multicolumn{2}{c|}{ Total } \\
\cline { 2 - 8 } & $\mathrm{N}$ & $\%$ & $\mathrm{~N}$ & $\%$ & $\mathrm{~N}$ & $\%$ \\
\hline Farming & 28 & 93.33 & 28 & 93.33 & 56 & 93.33 \\
\hline Forest resources extraction & 1 & 3.33 & 0 & 0 & 1 & 1.67 \\
\hline Carpenter/construction worker & 1 & 3.33 & 1 & 3.33 & 2 & 3.33 \\
\hline Government officer & 0 & 0 & 1 & 3.33 & 1 & 1.67 \\
\hline Total & 30 & 100 & 30 & 100 & 60 & 100 \\
\hline
\end{tabular}

Through the group discussion and household survey, the researcher saw that most of households living in HLNP relied on forest for firewood, timber and NTFPs products. Therefore, identifying forest resources extraction as main occupation was based on high forest access and purpose of extraction. In another word, if the respondent went to forest with high frequency such as several times per week or per ten days to find forest resources for selling, forest resource extraction would be considered his/her occupation.

Table 5.5: Distribution of respondents by sub occupation

\begin{tabular}{|l|c|c|}
\hline Criteria & $\mathrm{N}$ & $\%$ \\
\hline Have no off-farm and non-farm job & 33 & 55.0 \\
\hline Do farming as sub job & 2 & 3.33 \\
\hline Off-farm job (working on other farm) & 4 & 6.67 \\
\hline Non-farm job & & \\
Forest resource extraction & 2 & 3.33 \\
Construction worker & 4 & 6.67 \\
Running rice and maize milling shop & 4 & 6.67 \\
Carpenter & 3 & 5.0 \\
Tourism related activities & 5 & 8.33 \\
Local priest & 3 & 5.0 \\
\hline
\end{tabular}

Table 5.5 shows the number of respondent having sub occupation as well as percentage of their sub occupations. More than a half of total respondents had no activities besides doing farming. Several respondents which accounted for 3.33\% worked as government officers and did farming as the second occupation. $6.67 \%$ of the whole samples had off-farm job. With regard to non-farm job, 35\% of total households sampled had non-farm job in which tourism related activities accounted for the highest portion represented by $8.3 \%$ and it was followed by construction workers, self-business (milling shop) which equally accounted for $6.7 \%$ of total respondents. $5 \%$ of total respondents worked as carpenter in off crop season and $3.33 \%$ of the whole samples worked as forest resource extractor $(3.33 \%)$. 
Another five percent of respondents worked as local religious priest. They perform the sacred rituals for other households in the village in many traditional occasions such as harvest festival (called Lễ cúng lúa mới), praying good health for children, praying for family on birthday celebration of household member, preparation to build houses or cure diseases. After performing his/her tasks, the local priest is invited for party with the family and got paid by in-kind such as a pig head or pig leg.

\subsubsection{Lengths of stay}

In the core zone, twenty six respondents accounted for $86.7 \%$ stated that they have stayed in their village since they were born. The $13.3 \%$ remaining or 4 respondents migrated from other areas. All of them were male respondents in which three Red Dao men has stayed in Ta Trung Ho village for 5, 7, 8 years respectively because of marriage, called "ở rể" (stay in wife's house) and one Giay man moved to Seo My Ty village 19 years ago for working as local carpenter. In the buffer zone, twenty nine out of thirty respondents accounted for $96.7 \%$ stayed in the village since they were born. Only one Black H'mong respondent migrated to Sin Chai village 16 years ago due to marriage.

\subsection{Household characteristics}

\subsubsection{Household size and labor}

Households sampled in HLNP had household size of 6.17 and labor of 3.32 at average (Table 5.6). An independent-samples t-test was conducted to compare the household size of households sampled in core zone and buffer zone of HLNP. There was no significant difference in the number of household members for the core zone $(\mathrm{M}=6.77, \mathrm{SD}=2.82)$ and the buffer zone $(\mathrm{M}=5.57, \mathrm{SD}=2.23)$ in HLNP; $\mathrm{t}(58)=\mathrm{b} 1.824, \mathrm{p}=0.0730$. Similarly, there was no significant difference in the number of labors per household in the core zone $(\mathrm{M}=3.63, \mathrm{SD}=1.77)$ and the buffer zone $(\mathrm{M}=3.00, \mathrm{SD}=1.41)$ in HLNP; $\mathrm{t}(58)=-1.531, \mathrm{p}=$ 0.131 . These results suggest that zone does not have an effect on the household size and labor force.

Table 5.6: Household size and labor of households sampled

\begin{tabular}{|l|c|c|c|c|}
\hline Measure & Core zone & Buffer zone & Diff. & Total \\
\hline $\begin{array}{l}\text { Average household size (SD) } \\
\text { Minimum - Maximum }\end{array}$ & $\begin{array}{c}6.77(2.82) \\
3-13\end{array}$ & $\begin{array}{c}5.57(2.23) \\
1-11\end{array}$ & n.s. & $\begin{array}{c}6.17(2.59) \\
1-13\end{array}$ \\
\hline $\begin{array}{l}\text { Average number of labor (SD) } \\
\text { Minimum - Maximum }\end{array}$ & $\begin{array}{c}3.63(1.77) \\
2-8\end{array}$ & $\begin{array}{c}3.00(1.41) \\
1-6\end{array}$ & n.s. & $\begin{array}{c}3.32(1.62) \\
1-8\end{array}$ \\
\hline
\end{tabular}

Independent-samples T test, $5 \%$ level of error probability

A half of household sampled in the core zone had household size in range from 7 to 13 , which were double of this kind of households sampled in the buffer zone. There was no household with 1-2 members in the core zone whereas this kind of small household existed in the buffer zone (Table 5.7). The number of households having 3-4 household members and two labors were the same in the core zone and the buffer zone, which accounted for $23.33 \%$ of total respondents in each zone. Household size of 7-8 was dominant in the core zone represented by $30 \%$ total of respondents whereas household size of 5-6 was the biggest group in the buffer zone demonstrated by $36.66 \%$. Overview, $50 \%$ of households sampled in the core zone had from 7 to 13 members whereas $76.66 \%$ of households 
sampled in the buffer zone had size smaller than 7 member per one household.

Table 5.7: Distribution of households sampled by household size

\begin{tabular}{|c|c|c|c|c|c|c|c|c|}
\hline \multirow[t]{2}{*}{ Hh size } & \multirow{2}{*}{$\begin{array}{l}\text { Labor } \\
\text { Min-Max }\end{array}$} & \multirow{2}{*}{$\begin{array}{l}\text { Average no. } \\
\text { of labors }\end{array}$} & \multicolumn{2}{|c|}{ Core zone } & \multicolumn{2}{|c|}{ Buffer zone } & \multicolumn{2}{|c|}{ Total } \\
\hline & & & $\mathrm{N}$ & $\%$ & $\mathrm{~N}$ & $\%$ & $\mathrm{~N}$ & $\%$ \\
\hline $1-2$ & 1 & 1 & 0 & 0 & 2 & 6.66 & 2 & 3.33 \\
\hline $3-4$ & $2-3$ & 2.07 & 7 & 23.33 & 7 & 23.33 & 14 & 23.33 \\
\hline $5-6$ & $2-5$ & 2.77 & 8 & 26.66 & 14 & 36.66 & 22 & 36.66 \\
\hline $7-8$ & $2-6$ & 4.08 & 9 & 30 & 3 & 10 & 12 & 20 \\
\hline $9-10$ & $4-6$ & 5.33 & 3 & 10 & 3 & 10 & 6 & 10 \\
\hline $11-13$ & $4-8$ & 6.25 & 3 & 10 & 1 & 3.33 & 4 & 6.66 \\
\hline \multicolumn{3}{|c|}{ Total } & 30 & 100 & 30 & 100 & 60 & 100 \\
\hline
\end{tabular}

Throughout HLNP, 36.6\% of household sampled consisted of 5-6 members. It was followed by households having 3-4 members accounted for $23.33 \%$ of total household sampled and household with 7-8 members accounted for 20\%, respectively. Households with small or extremely big household size (1-2, 9-10 and 11-13 member/household) were less than $10 \%$ each.

\subsubsection{Land holding size and land use}

With regard to land tenure, in Vietnam, land is owned by the government and Vietnamese residents apply for their land use certification called Red book. During the survey, it has been know that the last land division in Sapa district, Lao Cai province was conducted in 1998.

Cardamom cultivated area belongs to the HLNP, therefore, local people do not have formal rights to use this kind of land. Paper work in Red Book application in Vietnam is complicated, especially to ethnic minority groups who has low education and literacy. Moreover, early marriage and high birth rate lead to the early separation of households in villages and division of land use area. All kinds of land use include terrace, upland field, fishpond, home garden, cardamom cultivated area was divided among sons of households and passed between generations.

Table 5.8 Distribution of households sampled by land holding size (not included cardamom cultivated area)

\begin{tabular}{|l|c|c|c|c|c|c|}
\hline \multirow{2}{*}{ Size of land holding (ha) } & \multicolumn{2}{|c|}{ Core zone } & \multicolumn{2}{c|}{ Buffer zone } & \multicolumn{2}{c|}{ Total } \\
\cline { 2 - 7 } & $\mathrm{N}$ & $\%$ & $\mathrm{~N}$ & $\%$ & $\mathrm{~N}$ & $\%$ \\
\hline Below 0.1 & 2 & 6.67 & 0 & 0 & 2 & 3.33 \\
\hline $0.1-0.49$ & 12 & 40 & 13 & 43.33 & 25 & 41.67 \\
\hline $0.5-0.99$ & 12 & 40 & 12 & 40 & 24 & 40 \\
\hline $1-1.5$ & 3 & 10 & 5 & 16.67 & 8 & 13.33 \\
\hline Over 2 & 1 & 3.33 & 0 & 0 & 1 & 1.67 \\
\hline Total & 30 & 100 & 30 & 100 & 60 & 10 \\
\hline
\end{tabular}


Table 5.9 Land holding and total land use area of households sampled

\begin{tabular}{|l|c|c|c|c|}
\hline Criteria & Core zone & Buffer zone & Diff. & Total \\
\hline $\begin{array}{l}\text { Land holding (not included cardamom } \\
\text { area) (ha) }\end{array}$ & & & & \\
$\begin{array}{l}\text { Average (SD) } \\
\text { Minimum - Maximum }\end{array}$ & $0.60(0.45)$ & $0.58(0.31)$ & n.s. & $0.59(0.38)$ \\
\hline Total land use area (included & $0.02-2.21$ & $0.13-1.36$ & & $0.02-2.21$ \\
cardamom area) (ha) & & & & \\
Average (SD) & $2.82(3.98)$ & $1.07(0.78)$ & $*$ & $1.95(2.98)$ \\
Minimum - Maximum & $0.49-22.22$ & $0.20-3.79$ & & $0.49-22.22$ \\
\hline
\end{tabular}

Mann-Whitney $U$ test, $5 \%$ level of error probability

The largest land holding of household sampled was found in the core zone (2.21 ha) and it was much higher than the largest holding in the buffer zone (1.36 ha) (Table 5.9). As shown in Table 5.8, there was a similarity of the number of households holding land area in range of $0.1-0.49$ ha and $0.5-0.99$ ha in two zones, which accounted for about $40 \%$. It led to the same portion of those kinds of households in HLNP overall. The core zone had $6.7 \%$ households sampled with land holding size less than $1000 \mathrm{~m} 2$ or 0.1 ha and $3.3 \%$ households sampled with land holding size over 2 ha, however, in the buffer zone, this kind of farm did not exist (Table 5.8). In general, average land holding of households sampled in the core zone was slightly higher than this one in buffer zone (Table 5.9) but there was no statistically significant difference between them. Overall, households sampled in HLNP had land holding size of 0.59 ha.

Table 5.10 Total land use area of households sampled (including cardamom cultivated area)

\begin{tabular}{|l|c|c|c|c|c|c|}
\hline \multirow{2}{*}{$\begin{array}{c}\text { Size of total land use } \\
\text { (ha) }\end{array}$} & \multicolumn{2}{|c|}{ Core zone } & \multicolumn{2}{c|}{ Buffer zone } & \multicolumn{2}{c|}{ Total } \\
\cline { 2 - 7 } & $\mathrm{N}$ & $\%$ & $\mathrm{~N}$ & $\%$ & $\mathrm{~N}$ & $\%$ \\
\hline Below 1 & 7 & 23.33 & 16 & 53.33 & 23 & 38.33 \\
\hline $1-2.99$ & 16 & 53.33 & 13 & 43.33 & 29 & 48.33 \\
\hline $3-4.99$ & 4 & 13.33 & 1 & 13.33 & 5 & 8.33 \\
\hline $6-7$ & 2 & 6.67 & 0 & 0 & 2 & 3.33 \\
\hline Over 20 & 1 & 3.33 & 0 & 0 & 1 & 1.67 \\
\hline Total & 30 & 100 & 30 & 100 & 60 & 100 \\
\hline
\end{tabular}

It is easy to see that total land use area (land holding plus cardamom cultivated area) of households sampled in the core zone was approximately 3 times higher than that one in the buffer zone (Table 5.10). Results of Man-Whitney U test shows that the total area of land use of households sampled in the core zone was statistically significant higher than those in the buffer zone (Table 5.9). In the whole samples, households have used area of 1.95 ha at average, which was approximately 1.4 ha higher than the land holding before plus forest farming area. The total land use area of households sampled in the core zone reached maximum of 22 ha, which was 6 times higher than the highest total land use area of households sampled in the buffer zone of HLNP (Table 5.9). About 55\% of households sampled in the core zone had total land use in the range from 1 to 2.99 ha whereas the buffer zone was dominant by households with total land use less than 1 ha. 


\subsubsection{Housing condition of households sampled}

Houses of local people in the HLNP are often wooden house made of valuable timber extracted from the HLNP. Among four selected village, houses of Red Dao ethnic group living in Ta Trung Ho village in the core zone were large and luxurious with glass window, water salinity, and decoration inside the house. They were followed by houses of Giay ethnic households in Ta Van Giay 1 village in the buffer zone with large house and water salinity which are used by both household members and visitors. With regard to two remaining villages, housing area was in range from $15 \mathrm{~m} 2$ to $400 \mathrm{~m} 2$ and lack of toilet and/or bathroom is popular. Percentage of households sampled having bathroom and toilet was very high in Ta Van Giay1 village (80\%) and low in Seo My Ty village (20\%). In Ta Trung Ho village, about 33\% households sampled had bathroom and 53\% had toilet. However, there was not any bathroom and toilet in Sin Chai village (Table 5.11).

Table 5.11: Housing condition of household sampled in four selected villages

\begin{tabular}{|c|c|c|c|c|c|c|c|c|}
\hline \multirow[b]{2}{*}{ Criteria } & & \multicolumn{4}{|c|}{ Village } & \multirow[b]{2}{*}{$\begin{array}{l}\text { Core } \\
\text { zone }\end{array}$} & \multirow[b]{2}{*}{$\begin{array}{l}\text { Buffer } \\
\text { zone }\end{array}$} & \multirow[b]{2}{*}{ Total } \\
\hline & & Seo My Ty & $\begin{array}{|ll|}\text { Ta } & \text { Trung } \\
\text { Ho } & \\
\end{array}$ & Sin Chai & $\begin{array}{l}\text { Ta Van } \\
\text { Giay1 }\end{array}$ & & & \\
\hline Have bathroom & $\mathrm{N}(\%)$ & $3(20)$ & $5(33.3)$ & $0(0)$ & $12(80)$ & $8(26.7)$ & $12(40)$ & $20(33.3)$ \\
\hline Have toilet & $\mathrm{N}(\%)$ & $3(20)$ & $8(53.3)$ & $1(6.7)$ & $12(80)$ & $11(36.7)$ & $13(43.3)$ & $23(38.3)$ \\
\hline $\begin{array}{l}\text { Electricity } \\
\text { National } \\
\text { Self-prepare } \\
\text { No use }\end{array}$ & $\mathrm{N}(\%)$ & $\begin{array}{l}8(53.3) \\
5(33.3) \\
2(13.3)\end{array}$ & $\begin{array}{l}0(0) \\
14(93.3) \\
1(6.7)\end{array}$ & $\begin{array}{l}13(86.7) \\
0(0) \\
2(13.3)\end{array}$ & $\begin{array}{l}15(100) \\
0 \\
0\end{array}$ & $\begin{array}{l}8(26.7) \\
19(63.3) \\
3(10)\end{array}$ & $\begin{array}{l}28(93.3) \\
0 \\
2(6.7)\end{array}$ & $\begin{array}{l}36(60) \\
19(31.7) \\
5(8.3)\end{array}$ \\
\hline $\begin{array}{l}\text { Roof } \\
\text { Metal roof } \\
\text { Wooden roof } \\
\text { Tiled roof }\end{array}$ & $\mathrm{N}(\%)$ & $\begin{array}{l}3(20) \\
12(80) \\
0(0)\end{array}$ & $\begin{array}{l}13(86.7) \\
0(0) \\
2(13.3)\end{array}$ & $\begin{array}{l}14(93.3) \\
1(6.7) \\
0(0)\end{array}$ & $\begin{array}{l}13(86.7) \\
1(6.7) \\
1(6.7)\end{array}$ & $\begin{array}{l}16(53.3) \\
12(40) \\
2(6.7)\end{array}$ & $\begin{array}{l}27(90) \\
2(6.7) \\
1(3.3)\end{array}$ & $\begin{array}{l}43(71.7) \\
14(23.3) \\
3(5)\end{array}$ \\
\hline $\begin{array}{l}\text { Floor } \\
\text { Soil ground } \\
\text { Ceramic } \\
\text { Marble }\end{array}$ & $\mathrm{N}(\%)$ & $\begin{array}{l}10(66.7) \\
5(33.3) \\
0(0)\end{array}$ & $\begin{array}{l}6(40) \\
3(20) \\
6(40)\end{array}$ & $\begin{array}{l}15(100) \\
0(0) \\
0(0)\end{array}$ & $\begin{array}{l}4(26.7) \\
8(53.3) \\
3(20)\end{array}$ & $\begin{array}{l}16(53.3) \\
8(26.7) \\
6(20)\end{array}$ & $\begin{array}{l}19(63.3) \\
8(26.7) \\
3(10)\end{array}$ & $\begin{array}{l}35(58.3) \\
16(26.7) \\
9(15)\end{array}$ \\
\hline
\end{tabular}

Concerning about electricity, most of households sampled in the buffer zone used electricity from national line. In contrast, a half of respondents in Seo My Ty village and total respondents in Ta Trung Ho village in the core zone used micro hydro and natural water flow to generate electricity for using. Several households in both core zone and buffer zone did not use electricity. Proportion of houses with metal roof was about $53 \%$ in the core zone and $90 \%$ in the buffer zone. In Sin Chai village, 100\% households lived in houses with soil ground where as there was an improvement from soil floor to ceramic floor in other villages. Especially, a small percentage of the whole samples lived in houses with marble floor, for example, in Ta Trung Ho village in the core zone and Ta Van Giay1 village in the buffer zone.

Over all, about one third of total households sampled had toilet and bath room, of which $60 \%$ are Giay ethnic households in Ta Van Giayl village in the buffer zone. 92\% of the whole samples used electricity in which $60 \%$ came from national lines and $32 \%$ remaining selfprepared electricity by using micro hydro and natural flow of water. Two third of total 
households sampled had metal roof whereas about one fourth of total households sampled had wooden roof. More than a half of the whole samples stayed in houses with soil floor. The remaining had improved to ceramic floor (26\%) and marble floor (15\%).

\subsubsection{Household assets}

Proportion of households which have television in the core zone was higher than that one in the buffer zone (73.3\% versus $66.7 \%$ ) and so did the average number of television per households ( 0.9 versus 0.73 ). With regard to transportation, motorbike was more popular in the core zone than in the buffer zone. 93\% of households sampled in the core zone had motorbike whereas this proportion in the buffer zone was 67\%. Ta Trung Ho and Ta Van Giay village had the highest proportion of possessing television and motorbike (Table 5.12). Refrigerator was common in Ta Van Giay village in the buffer zone where local used refrigerator to preserve food and drink for tourists. In other villages, there was not any household having refrigerator. Computer/laptop and washing machine were available in Ta Van Giay1 village in the buffer zone with a very low proportion.

Table 5.12 Main assets of households sampled in four selected village

\begin{tabular}{|c|c|c|c|c|c|c|c|c|}
\hline \multirow{2}{*}{ Asset } & \multirow{2}{*}{ Measure } & \multicolumn{4}{|c|}{ Village } & \multirow[b]{2}{*}{$\begin{array}{l}\text { Core } \\
\text { zone }\end{array}$} & \multirow[b]{2}{*}{$\begin{array}{l}\text { Buffer } \\
\text { zone }\end{array}$} & \multirow{2}{*}{ Total. } \\
\hline & & $\begin{array}{ll}\text { Seo } & \text { My } \\
\text { Ty } & \end{array}$ & $\begin{array}{ll}\text { Ta } & \text { Trung } \\
\text { Ho } & \end{array}$ & Sin Chai & $\begin{array}{l}\text { Ta Van } \\
\text { Giay1 }\end{array}$ & & & \\
\hline Television & $\begin{array}{l}\mathrm{N}(\%) \\
\text { Mean }\end{array}$ & $\begin{array}{l}10(66.7) \\
0.80\end{array}$ & $\begin{array}{l}12(80) \\
1\end{array}$ & $\begin{array}{l}5(33.3) \\
0.40\end{array}$ & $\begin{array}{l}15(100) \\
1.07\end{array}$ & $\begin{array}{l}22(73.3) \\
0.9\end{array}$ & $\begin{array}{l}20(66.7) \\
0.73\end{array}$ & $\begin{array}{l}42(70) \\
0.82\end{array}$ \\
\hline Motorbike & $\begin{array}{l}\mathrm{N}(\%) \\
\text { Mean }\end{array}$ & $\begin{array}{l}14(93.3) \\
1.33\end{array}$ & $\begin{array}{l}14(93.3) \\
1.6\end{array}$ & $\begin{array}{l}7(46.7) \\
0.53\end{array}$ & $\begin{array}{l}13(86.7) \\
1.27\end{array}$ & $\begin{array}{l}28(93.3) \\
1.47\end{array}$ & $\begin{array}{l}20(66.7) \\
0.90\end{array}$ & $\begin{array}{l}48(80) \\
1.18\end{array}$ \\
\hline Refrigerator & $\begin{array}{l}\mathrm{N}(\%) \\
\text { Mean }\end{array}$ & $\begin{array}{l}1(6.7) \\
0.07\end{array}$ & 0 & 0 & $\begin{array}{l}10(66.7) \\
0.67\end{array}$ & $\begin{array}{l}1(3.3) \\
0.03\end{array}$ & $\begin{array}{l}10(33.3) \\
0.33\end{array}$ & $\begin{array}{l}11(18.3) \\
0.18\end{array}$ \\
\hline $\begin{array}{l}\text { Computer/ } \\
\text { laptop }\end{array}$ & $\begin{array}{l}\mathrm{N}(\%) \\
\text { Mean }\end{array}$ & 0 & 0 & 0 & $\begin{array}{l}3(20) \\
0.27\end{array}$ & 0 & \begin{tabular}{|l|}
$3(10)$ \\
0.13
\end{tabular} & $\begin{array}{l}3(5) \\
0.07\end{array}$ \\
\hline $\begin{array}{l}\text { Washing } \\
\text { machine }\end{array}$ & $\begin{array}{l}\mathrm{N}(\%) \\
\text { Mean }\end{array}$ & 0 & 0 & 0 & $\begin{array}{l}3(20) \\
0.20\end{array}$ & 0 & \begin{tabular}{|l|}
$3(10)$ \\
0.1
\end{tabular} & $\begin{array}{l}3(5) \\
0.05\end{array}$ \\
\hline $\begin{array}{l}\text { Mini } \\
\text { ploughing } \\
\text { machine }\end{array}$ & $\begin{array}{l}\mathrm{N}(\%) \\
\text { Mean }\end{array}$ & 0 & $\begin{array}{l}3(20) \\
0.20\end{array}$ & $\begin{array}{l}1(6.7) \\
0.07\end{array}$ & $\begin{array}{l}4(26.7) \\
0.27\end{array}$ & $\begin{array}{l}3(10) \\
0.1\end{array}$ & $\begin{array}{l}5(16.7) \\
0.17\end{array}$ & $\begin{array}{l}8(13.3) \\
0.13\end{array}$ \\
\hline $\begin{array}{l}\text { Rice huller } \\
\text { machine }\end{array}$ & $\begin{array}{l}\mathrm{N}(\%) \\
\text { Mean }\end{array}$ & $\begin{array}{l}1(6.7) \\
0.07\end{array}$ & $\begin{array}{l}3(20) \\
0.20\end{array}$ & $\begin{array}{l}1(6.7) \\
0.07\end{array}$ & $\begin{array}{l}2(13.3) \\
0.13\end{array}$ & $\begin{array}{l}4(13.3) \\
0.13\end{array}$ & \begin{tabular}{|l|}
$3(10)$ \\
0.1
\end{tabular} & $\begin{array}{l}7(11.6) \\
0.12\end{array}$ \\
\hline $\begin{array}{l}\text { Rice shredder } \\
\text { machine }\end{array}$ & $\begin{array}{l}\mathrm{N}(\%) \\
\text { Mean }\end{array}$ & 0 & $\begin{array}{l}12(80) \\
0.87\end{array}$ & 0 & 0 & $\begin{array}{l}12(40) \\
0.43\end{array}$ & 0 & $\begin{array}{l}12(20) \\
0.22\end{array}$ \\
\hline
\end{tabular}

Several kinds of agricultural machine were used in both zones of the HLNP, however, a few households could afford. Rice huller machine were available in all four selected village so that local could hulling rice and milling maize. Several households had mini ploughing machine. Most of households sampled in Ta Trung Ho village used rice shredder machine whereas households sampled in three remaining villages did not use. In general, among villages, Ta Trung Ho villages used agricultural machine the most and it was followed by Ta Van Giay 1 village. In brief, proportion of households sampled possessing agricultural machine in the core zone was higher than that one in the buffer zone.

Overall, television and motorbike are two popular assets of households sampled. The number of households having these two amenities accounts for 70 and $80 \%$ of the whole 
sample, respectively. $10 \%$ of the whole samples had refrigerator but most of them are Giay ethnic households in the buffer zone which operate home-stay service for tourists. This portion might increase in the future because some respondents in Ta Trung Ho village stated that they could buy refrigerator easily; lack of electricity from national line was the reason for their non-use of refrigerator. The proportion of households which possess agricultural machine was under one fifth of the whole samples.

\subsubsection{Household's total net cash income}

No households sampled in the core zone earned net cash income below 10 million VND /year whereas $13.33 \%$ of households sampled in the buffer zone did (Table 5.13). The highest total net cash income generated by households in the core zone was 455 million VND which was about 2.5 times higher than that one in the buffer zone. There was a similarity that $43.33 \%$ of total household sampled in both zones earned net cash income in range from 10 million VND to 30 million VND per year. Households sampled gained net cash income from 30 to 60 million VND/ year, 60 to 100 million VND/ year in the core zone were higher than those ones in the buffer zone. Especially, one household in the core zone earned 450 million VND as total net cash income.

Table 5.13 Distribution of households sampled by total net cash income

\begin{tabular}{|c|c|c|c|c|c|c|}
\hline \multirow{2}{*}{$\begin{array}{l}\text { Total net cash income } \\
\text { (million VND/year) }\end{array}$} & \multicolumn{2}{|c|}{ Core zone } & \multicolumn{2}{|c|}{ Buffer zone } & \multicolumn{2}{|c|}{ Total } \\
\hline & $\mathrm{N}$ & $\%$ & $\mathrm{~N}$ & $\%$ & $\mathrm{~N}$ & $\%$ \\
\hline$<10$ & 0 & 0 & 4 & 13.33 & 4 & 6.67 \\
\hline $10 \rightarrow 30$ & 13 & 43.33 & 13 & 43.33 & 26 & 43.33 \\
\hline $30 \rightarrow 60$ & 6 & 20 & 4 & 13.33 & 10 & 16.67 \\
\hline $60 \rightarrow 100$ & 7 & 23.33 & 5 & 16.67 & 12 & 20 \\
\hline $100 \rightarrow 200$ & 3 & 10 & 4 & 13.33 & 7 & 11.67 \\
\hline 450 & 1 & 3.33 & 0 & 0 & 1 & 1.66 \\
\hline Total & 30 & 100 & 30 & 100 & 30 & 100 \\
\hline \multirow{3}{*}{$\begin{array}{l}\text { Yearly total net cash } \\
\text { income } \\
\text { (million VND/hh) }\end{array}$} & \multicolumn{4}{|c|}{ Village } & \multicolumn{2}{|c|}{ Zone } \\
\hline & Seo My Ty & $\begin{array}{l}\text { Ta Trung } \\
\text { Ho }\end{array}$ & Sin Chai & $\begin{array}{c}\text { Ta Van Giay } \\
1\end{array}$ & Core zone & Buffer zone \\
\hline & 48 & 73 & 24 & 62 & 61 & 43 \\
\hline (million VND/capita) & 7.0 & 10.6 & 4.3 & 13.2 & 8.8 & 8.7 \\
\hline
\end{tabular}

In general, total net cash income of households sampled in the core zone was higher than that one in the buffer zone (61 million VND/ year versus 43 million VND/ year). Among four selected village, Ta Trung Ho village in the core zone where Red Dao ethnic group live had the total net income of 73 million VND/household/year. It was about 3 times higher than the total net income of households sampled in Sin Chai village in the buffer zone where Black H'mong ethnic group live. Ta Van Giay 1 village in the buffer zone where most of Giay ethnic group stay had total net cash income of 62 million VND/ household/ year. Among three ethnic groups, Black H'mong ethnic households earned the lowest total net cash income. Yearly net cash income per capita in four selected villages were much different from each other, however, it was similar in two zones represented by approximately 9 million/ capita/ year. 


\section{Chapter 6}

\section{Agricultural production in HLNP}

\subsection{Current crops, variety and purpose of cultivation}

With regard to main crops, the household survey gave the result that $95 \%$ households sampled grew rice, approximately 92\% households sampled planted maize, $76 \%$ households sampled grew sweet potato whereas only $20 \%$ household planted cassava. With regard to vegetables, among whole samples, 92\% grew chayote, $83 \%$ grew Brassica juncea, $75 \%$ planted pumpkin, $67 \%$ grew taro, $33 \%$ grew kohlrabi and $50 \%$ grew cabbage. However, the number of households selling those main crops was very low. In the contrary, $76 \%$ household planted cardamom and all of them sold dried cardamom fruit to get cash income (Figure 6.1).

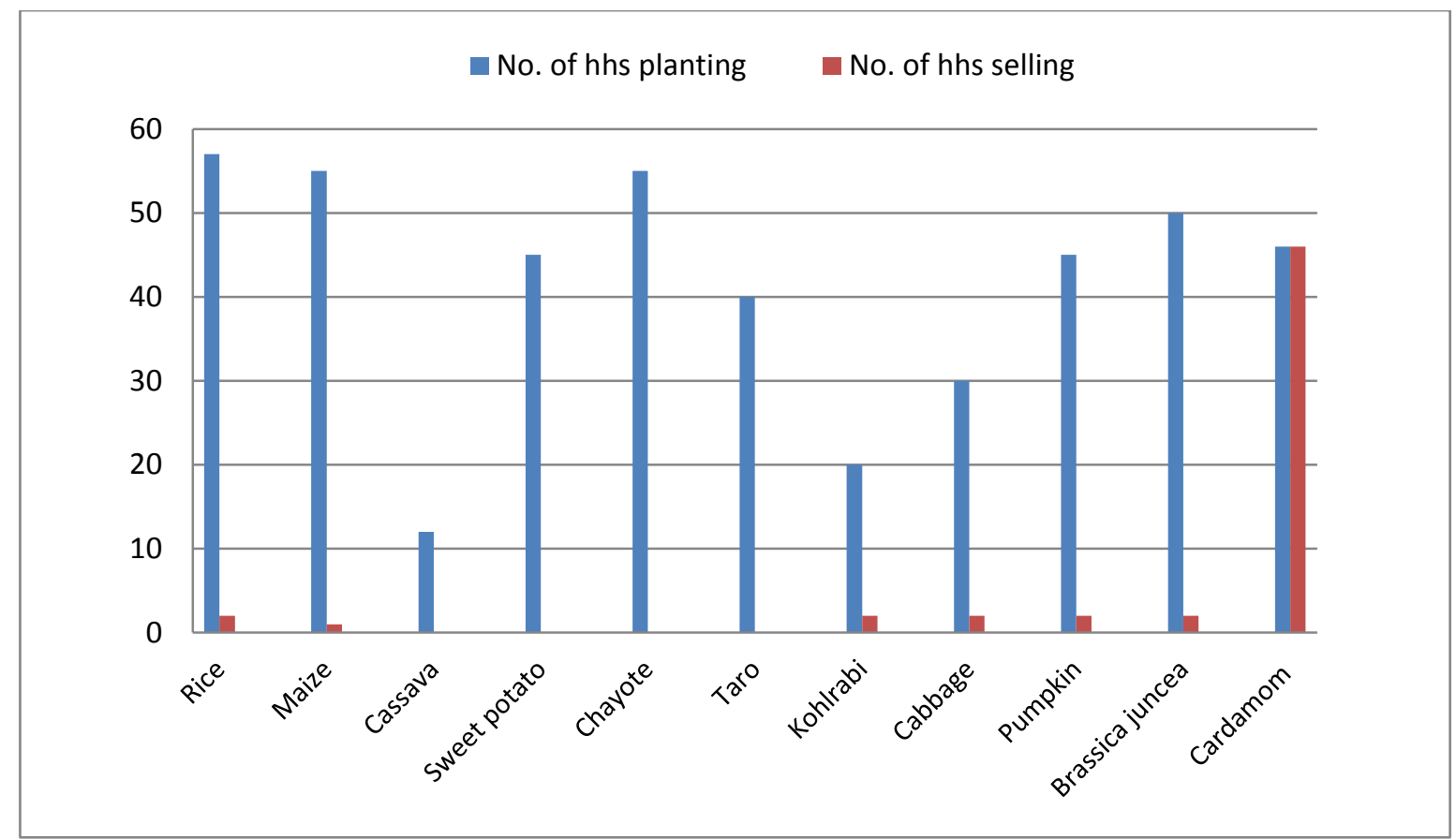

Figure 6.1 Number of households sampled grew and sold main types of crops

With regard to crop variety, local farm households in HLNP used both traditional variety and hybrid variety, however, use of hybrid cereal variety to get higher crop yield was dominant in both zones of the national park. Among the whole sample, about $30 \%$ grew only traditional maize whereas only $3 \%$ or $4 \%$ of total households sampled grew only traditional rice (Figure 6.2). It shows that use of traditional variety is more popular in maize cultivation than rice cultivation. Besides, for both kinds of cereals, households sampled in the core zone used more hybrid variety than those in the buffer zone. Number of households sampled grew both hybrid variety and traditional variety in the buffer zone was also higher than that one in the core zone. Traditional rice was used for making traditional food or other processed agricultural products after harvesting, for example: Cốm, 5-color and rainbow sticky rice made by Giay ethnic group in Ta Van Giay 1 village and Tay ethnic group in Ban Ho commune, traditional cake and sticky rice in Black H'mong and Red Dao village. Variety of other kinds of crops such as soy bean, potato, sweet potato, taro, cabbage, kohlrabi... were mostly prepared by farmers at the end of each crop season. Therefore, local households could easily grow them every year and reduce production cost. 


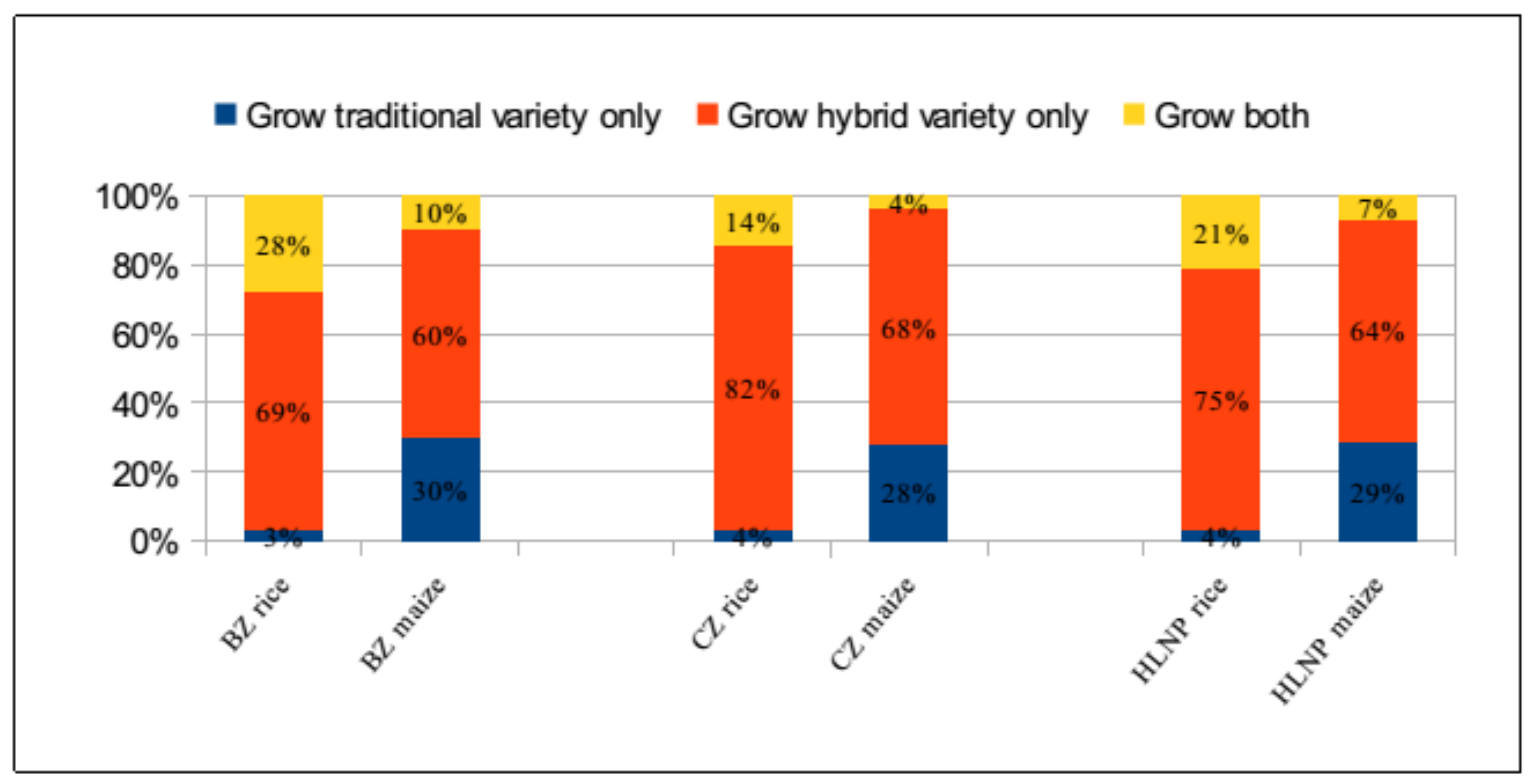

BZ: Buffer zone, CZ: Core zone

Figure 6.2: Use of variety in cultivation of rice and maize in HLNP.

\subsection{Farming calendar}

Weather of Sapa district where HLNP is located is cool in the whole year. The annual temperature ranges from $8^{\circ} \mathrm{C}$ to $20^{\circ} \mathrm{C}$ and the mean annual temperature is $15^{\circ} \mathrm{C}$. Sometimes, it has snow falls. Climate of HLNP is characterized of one dry-cold season (October - April) and one rainy-warm season (May - September) (Figure 6.3). Therefore, local people take the best use of open water and warm temperature in rainy season to grow crops.

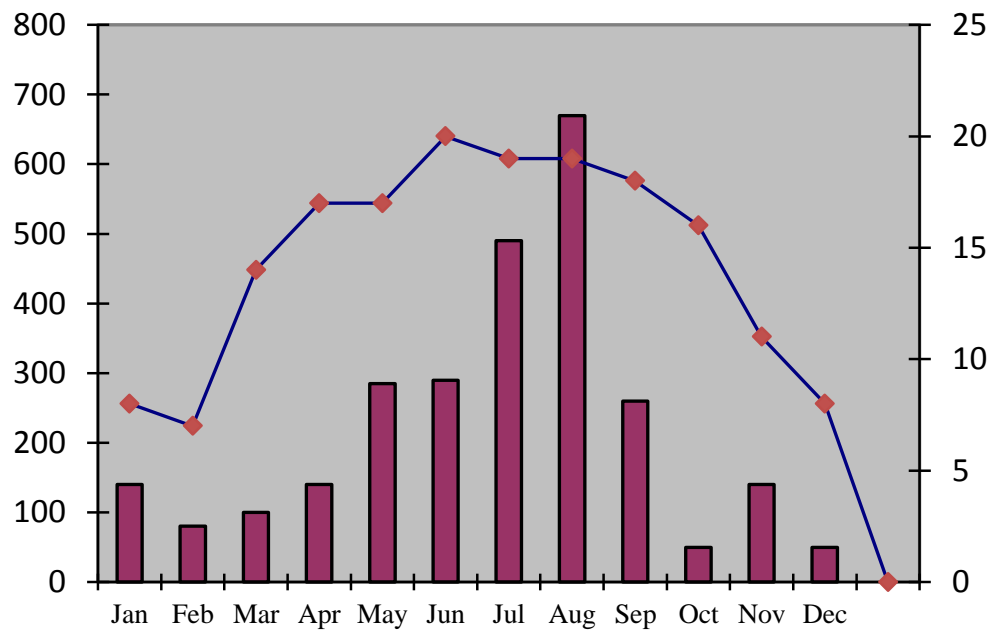

$\square$ Precipitation (mm) $\rightarrow-$ Temperature $\left({ }^{\circ} \mathrm{C}\right)$

Figure 6.3 Precipitation and temperature of Sapa district, Lao Cai province, Vietnam.

Results from group discussion show that periods of cultivation these crops were little different between villages and communes. Therefore, it was possible to construct a general farming calendar for main kinds of crops as shown in the Table 6.1 below. Almost local household in HLNP cultivated one crop season of stable food (rice, maize) and vegetables. These crops were often planted at the beginning of rainy season and harvested at the beginning of dry season. Crops which do not require much water such as maize, taro and 
cassava were usually planted at the end of dry season. Vegetables in HLNP are crops suitable with cool weather. Those vegetables were planted at the end of year and harvested till February in the following year.

With regard to perennial crops, cassava was planted in March or April and farmers could harvest it the 1st time at 5 months after planting. If not, local people can let it continue grow and harvest during 2 years. Cardamom is transplanted in 3 year after seeding and first harvested in 3 to 4 years after transplanting. Then, local can harvested cardamom annually in period from 10 to 15 years after the first harvest; however, the crop yield will reduce steadily.

Table 6.1 Farming calendar of local people living in the HLNP

\begin{tabular}{|c|c|c|c|c|c|c|c|c|c|c|c|c|c|}
\hline \multirow[b]{2}{*}{ Crop } & \multicolumn{13}{|c|}{ Activities } \\
\hline & Jan & Feb & Mar & Apr & May & Jun & Jul & Aug & Sep & Oct & Nov & Dec & $\begin{array}{l}\text { Jan } \\
\text { next }\end{array}$ \\
\hline Rice & & & & PL & PL & TR & & & HA & HA & & & \\
\hline Maize & & SE & & & & HA & & & & & & & \\
\hline $\begin{array}{l}\text { Cassava } \\
\text { (in Ban Ho } \\
\text { commune) }\end{array}$ & HA & & SE & SE & & & & $\begin{array}{l}\text { Start } \\
\text { HA }\end{array}$ & $\begin{array}{l}\text { Cass } \\
\text { years }\end{array}$ & va ca & be ha & vested & \\
\hline $\begin{array}{l}\text { Sweet } \\
\text { potato }\end{array}$ & & & & & & $\begin{array}{l}\text { PL, } \\
\text { TR }\end{array}$ & & & & HA & HA & HA & \\
\hline Taro & & & SE & SE & & & & & & HA & HA & HA & \\
\hline Soybean & & & & & & & $\begin{array}{l}\text { PL, } \\
\text { SE }\end{array}$ & WE & & & HA & & \\
\hline $\begin{array}{l}\text { Winter } \\
\text { vegetables } \\
\text { (Cabbage, } \\
\text { Kohlrabi...) }\end{array}$ & HA & & & & & & & & & SE & & HA & HA \\
\hline Cardamom & & & & & $\begin{array}{l}\mathrm{TR} \text { at } \\
\text { after } \mathrm{s}\end{array}$ & $\begin{array}{l}\text { 3years } \\
\text { eding }\end{array}$ & & & & $\begin{array}{l}\text { WE } \\
\text { start } \\
\text { years }\end{array}$ & $\begin{array}{l}\text { arly, } \\
\text { A yea } \\
\text { fter pl }\end{array}$ & $\begin{array}{l}\text { at } 3 \\
\text { titing }\end{array}$ & \\
\hline
\end{tabular}

$P L=$ Prepare Land,$T R=$ Transplanting,$W E=$ Weeding,$H A=$ Harvesting, $S E=$ Seeding/Planting

According to this farming calendar, there are several months that local people may lack of labor due to different work at same time such as April (maize seeding, planting cassava and prepare land for rice cultivation), May (continue land preparation for rice cultivation) and transplanting young-age cardamom, Jun (transplanting rice, sweet potato, cardamom along with harvest maize) and at the end of rainy season when output of some crops need to be harvested. Lack of labor may be serious at cardamom harvest season because labors of households planting cardamom will access forest and stay there for harvesting, weeding, trashing and drying fresh cardamom until they carry dried cardamom fruits home. They always bring rice and food such as meat, dried fish and pumpkin to the field and stay in temporal wooden house near their fields. In this time, households has small land holding and limited work can work for other farm households to get cash income or in-kind. In this period, households which have limited agricultural land or finish crop season before others have opportunities to earn additional cash income from off farm job. 


\subsection{Cropping system}

\subsubsection{Rice production in terrace}

The Black H'mong, Red Dao as well as The Giay ethnic minority group in Sapa district, Lao Cai province has a long history of paddy rice cultivation in form of terraced land. Terraced field was constructed near water source such as valleys and hillsides nearby of Muong Hoa river and Ta Trung Ho river, or on sloping land where water available. Areas chosen to construct terrace must be fertile soil and slight slope to ensure water taken through each terrace step was kept inside bunds. Due to small and narrow area, livestock such as buffalo, cow or small ploughing machine are used to plough the field.

During the survey, the researcher asked old respondents about new terrace area constructed by the respondent, however, all respondents stated that they had seen terrace since they were small. Their parents inherited terraces from their grandparents and they continues pass from their generation to their children (sons). They responded that the previous land area was large and they did not sell rice, therefore, they cleared forest for shifting cultivation until the HLNP was established which bans shifting cultivation and most of forest resource extraction activities. The area of new constructed terrace was very little in the village. Local people check and fix the terrace bunds before each crop season to store water for paddy rice cultivation. Some households use a small terraced area close to their houses to grow vegetables after harvesting rice.

Mono-cropping of wet rice in terraced field for subsistence is the dominant farming system of local people in Hoang Lien national park. It is also the typical characteristic of this region which attracts million tourists visit Sapa each year.

Table 6.2 Land use area per capital in core zone and buffer zone of HLNP

\begin{tabular}{|l|l|l|l|}
\hline Land use area per capita & Core zone & Buffer zone & Diff. \\
\hline Per-capita rice cultivated area $(\mathrm{m} 2)$ & $590.51(352.12)$ & $707.94(370.84)$ & n.s. \\
\hline Per-capita home garden area $(\mathrm{m} 2)$ & $54.75(82.46)$ & $30.76(40.82)$ & n.s. \\
\hline Per-capita maize cultivated area $(\mathrm{m} 2)$ & $187.48(133.02)$ & $337.49(363.15)$ & $*$ \\
\hline Per-capita cardamom cultivated area (m2) & $3259.53(3989.65)$ & $853.84(1167.98)$ & $*$ \\
\hline Per-capita house area (m2) & $23.25(14.53)$ & $23.55(18.65)$ & n.s. \\
\hline Per-capita fishpond area (m2) & $1.33(7.30)$ & $1.08(4.23)$ & n.s. \\
\hline $\begin{array}{l}\text { Per-capita farm size (m2) } \\
\text { (not include cardamom area) }\end{array}$ & $918.94(603.36)$ & $1101.63(454.64)$ & n.s. \\
\hline $\begin{array}{l}\text { Per-capita total land use (m2) } \\
\text { (including cardamom area) }\end{array}$ & $4178.48(4434.38)$ & $1955.48(1204.46)$ & $*$ \\
\hline
\end{tabular}

Notes: Standard deviation in parenthesis

* statistically significant at a 5\% level of error probability

Mann Whitney $U$ test

Table 6.2 shows the difference between areas per capita for each kind of land use in two zones of HLNP. Rice cultivated area per capita in the core zone was $590.51 \mathrm{~m} 2$ in average. Paddy cultivated area per capita in the buffer zone was $707.94 \mathrm{~m} 2$ but not statistically 
significantly higher than the one in the core zone $(U=368.5, p=0.228)$. Comparing the farm size per capita in two zone using Mann Whitney $U$ test gave the result that there were not statistically significant difference. Paddy share in land holding in both zones of the HLNP were about $64 \%$.

There was a similarity in rice cultivated area per household in the core zone and the buffer zone of the HLNP represented by the average area of approximate $4000 \mathrm{~m} 2$ (Table 6.3 below). There was no statistically significant difference in rice cultivated area per household in two zones (Mann Whitney $U$ test was applied, $U=437, \mathrm{p}=0.847$ ).

Because cardamom cultivated area significantly change the area of farm size as analyzed in previous chapter of this thesis, it also brought significant difference in total land use per capita in two zones. Application of Mann Whitney U test, applied to compare the average total land use per capita of two zones gave results that total land use per capita in the core zone of $4178.48 \mathrm{~m} 2$ is statistically significant higher than that one of the buffer zone difference (Table 6.2). Paddy share in the core zone was $14 \%$ which is much smaller than paddy share in the buffer zone of $36 \%$.

\subsubsection{Rice security}

Results indicated that local people in HLNP mostly grew one rice crop season per year for home consumption and raising livestock. However, not all households produced enough rice. During the survey, the researcher asked the amount of seed instead of the area cultivated because the respondent could not estimate their cultivated area. Moreover, the researcher also asked the number of unhusked rice sacks with average weight of 45 kilos obtained after harvesting and drying to calculate the crop yields. Moreover, during conducting PRA in four selected village and interviewing household heads, the researcher asked the number of rice sacks obtained if villagers grow one kilo of rice seed in their fields, however, various responses point out that rice crop yield was different among households and villages. There were households have abundant rice whereas other lack of rice. Results indicated that rice crop yield in Ta Trung Ho village and Ta Van Giayl village was higher than that of two other villages.

Table 6.3 Rice security status of households sampled in HLNP

\begin{tabular}{|l|c|c|c|c|c|c|c|}
\hline \multirow{2}{*}{ Criteria } & \multicolumn{5}{|c|}{ Village } & \multicolumn{2}{c|}{ Zone } \\
\cline { 2 - 7 } & $\begin{array}{l}\text { Ta Trung } \\
\text { Ho (N=15) }\end{array}$ & $\begin{array}{l}\text { Seo My Ty } \\
(\mathrm{N}=15)\end{array}$ & $\begin{array}{l}\text { Sin Chai } \\
(\mathrm{N}=15)\end{array}$ & $\begin{array}{l}\text { TaVan Giay1 } \\
(\mathrm{N}=15)\end{array}$ & $\begin{array}{l}\text { Core zone } \\
(\mathrm{N}=30)\end{array}$ & $\begin{array}{l}\text { Buffer zone } \\
(\mathrm{N}=30)\end{array}$ & $\begin{array}{c}\text { Total } \\
(\mathrm{N}=60)\end{array}$ \\
\hline $\begin{array}{l}\text { No. of hhs } \\
\text { produce not } \\
\text { enough rice }\end{array}$ & 0 & 12 & 11 & 4 & 12 & 15 & 27 \\
\hline$\%$ & $0 \%$ & $80 \%$ & $73.33 \%$ & $26.66 \%$ & $40 \%$ & $50 \%$ & $45 \%$ \\
\hline $\begin{array}{l}\text { Rice area/hh } \\
(\mathrm{m} 2 / \mathrm{hh})\end{array}$ & 4134 & 3796 & 4001 & 3973 & $3965 \mathrm{a}^{*}$ & $3987 \mathrm{a}$ & 3976 \\
\hline
\end{tabular}

* statistically significant at a $5 \%$ level of error probability

Mann Whitney $U$ test

Table 6.3 represents the rice security status of households sampled in four selected villages and two different zone of HLNP. In the core zone, $100 \%$ households sampled in Ta Trung Ho village produced enough rice including several poor households having poor 
certification. On the contrary, Seo My Ty village had 12 households corresponding to $80 \%$ of total households sampled lack of rice and they had to purchase more rice for home consumption, in which 11 households did not produce enough rice and 1 household did not cultivate rice. In the buffer zone, $40 \%$ of total households sampled in Ta Van Giay 1 village had to purchase rice. In Sin Chai village where the poverty was highest among four selected village, $100 \%$ households sampled produced not enough rice. Overall, $40 \%$ of total households sampled in the core zone and a half of households sampled in the buffer zone had to purchase rice. For the whole samples, 27 households corresponding to $45 \%$ of total households sampled in HLNP had to purchase rice.

Between two villages located in the core zone of the HLNP, $80 \%$ of households in Seo My Ty village had to purchase rice for home consumption whereas even poor households in Ta Trung Ho villagers had enough rice for subsistence. Besides reasons such as rice cultivated area, soil quality, the construction of Seo Trung Ho hydrological lake and dam in Seo My Ty village in 2003 was among causes of hunger in this Black H'mong village.

\section{Case study: Seo My Ty village}

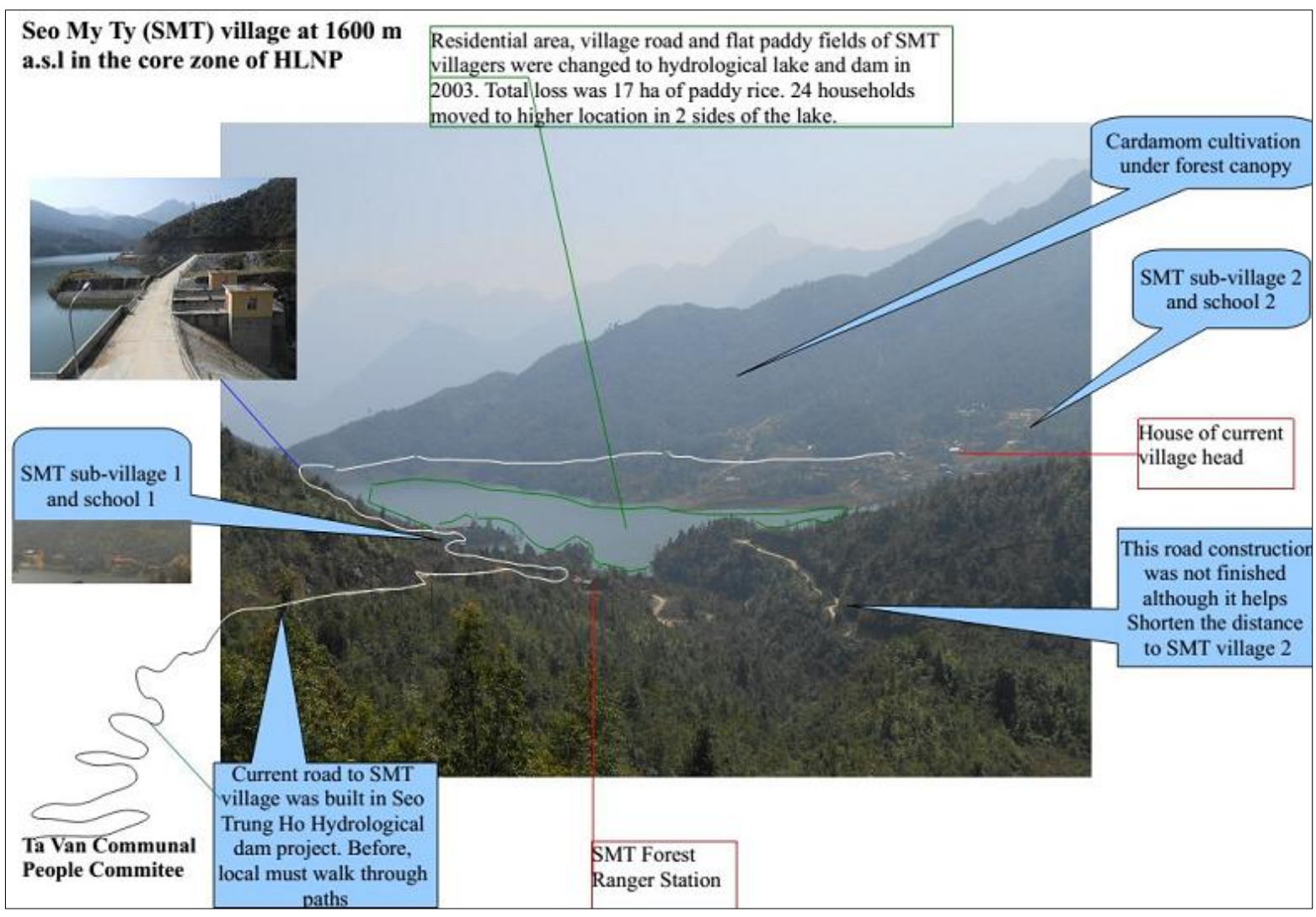

Figure 6.4: Effects of Seo Trung Ho hydro power project on land use in Seo My Ty village

Before the project, Seo My Ty villagers had large flat paddy land for rice cultivation and enough rice for subsistence. However, this rice valley with area of 17 ha (according to Village head of Seo My Ty village) had become the hydrological lake and dam (Figure 6.3). Besides, 24 households which stayed in this valley had to move to higher location in two sides of the lake. Paddy area loss was paid in cash with $18000 \mathrm{VND} / \mathrm{m} 2$ (about 1.5 USD). Moreover, the project convinced the local people that other land area would be given to farmers for cultivation. Some households used the payment for buying land in other adjacent areas for rice cultivation such as Den Thang $(5 \mathrm{~km}$ further in the core zone, limited 
transportation), Lao Chai (10km distance, in the buffer zone), Giang Ta Chai Mong, Giang Ta Chai Giao, Ta Van Giay (12 km distance, in the buffer zone), however, the crop yield on their new terraced fields was much lower than their old flat fields. Land given by the project later was located on the way from Seo My Ty to Den Thang which was at higher elevation than the flat land in valley. Several households used that land for rice cultivation for 1 or 2 years. Then, they had to stop because of too low crop yield. Besides households purchased land in other areas, other households spent payment to buy household furniture and enjoy party because they suddenly had a high amount of money. Then, they have no money left for purchase land, land given by the project was not productive, even grass could not grow in some parts. That's why they have no paddy land or very limited paddy land which located higher in two sides of the lake. At several first years, when the lake was not full of water, villagers could cultivate land in some parts for subsistence, however, at present, the water level is relatively stable.

With regard to 24 households moving out of the valley, each household was supported a new housing floor in sub village 2 (Figure 6.4), a water tank made of cement, electricity and an incentive of 90 million VND for moving whatever the size of the house is. 20 households have moved following the arrangement of the project. Several other households got that incentive and moved to other locations by themselves. These households own that housing floor as an unused land.

In this project, local government which representatives are The People committee of $\mathrm{Sa} \mathrm{Pa}$ district promised Seo My Ty villagers that the government would use money to buy cultivated area and give to local along with supply rice for each capita for 3 years. The 1 st task had been done, however, households which loss land did not receive low productive land given by the project. To solve that problem, one more time, the project decided to pay villager in cash, then, each household could find better land area and purchase by themselves. However, until now, this task was not done. The second task which provides villagers with rice per capita was also in same situation. Seo My Ty village head have sent papers to People committee of Ta Van commune as well as $\mathrm{SaPa}$ district to solve the problem since 2004; however, there was no reply. At present, households have cultivated rice area may produce enough rice for home consumption although transportation cost increase due to further distance from house to paddy fields. $80 \%$ of households lack of rice for home subsistence.

The construction of Seo Trung Ho project has both positive and negative effects on Seo My Ty villagers. Main positive effects were the construction of the road which connects Seo My Ty village with Ta Van commune in the buffer zone and Den Thang commune in the core zone. During the project, trucks carry construction material to build the lake and dam, and later local use this road for transporting cardamom to Ta Van commune and Sapa town. Vice versa, traders from Sapa could go to villages in the core zone for buying cardamom. Primary negative effects was the loss of flat paddy fields and hunger of Seo My Ty villagers due to non-productive land given by the project and mismanagement in using payment of local for their land loss. The fact that the project did not supply rice for consumption in the first three years cause the problem become more serious. At present, cardamom is the only source of cash income of almost Seo My Ty villagers. Moreover, at present, it it difficult to transport to the sub village Seo My Ty 2 located at the other size of the lake. Before the project, households can easily go around through paddy bunds and housing road in the valley. After the project, they have to go around the lake to reach another sub village. The road is full of mud when it rains which cause difficulties in transportation in rainy season. In the future, if the second road is finished constructing, it is 
very useful for local people. Another fact is that despite contribution for hydrological project, many households in Seo My Ty village have no electricity from national line to use. Instead, these households generate electricity by themselves using a small engine power and water flow which they call "water electricity".

"If we do not have cardamom, we die. There is nothing to sell to get money. Paddy fields are too far and low crop yield" - The old village head of Seo My Ty village.

"We lost our land due to the project. But we are not supplied electricity from national line like other villages. It's not fair. Even the name of the dam is also name of another village although that village did not lose any land for the construction" - Mr M, supposed name, Seo My Ty villager

"The government convinced us for giving land to build a hydrological dam here. But we do not agree. They asked me to convince households in my village. But most of people say no. Let's see Seo My Ty villagers, now they have no land and their livelihood is based on cardamom. Fortunately, they still have cardamom. If not, they will be more miserable" Village head of Ta Van Giay village in the buffer zone.

\subsubsection{Maize cultivation on sloping field}

In HLNP, local ethnic minority group plant maize on sloping field. In Ban Ho commune, cassava is also planted on sloping fields which has light slope. Before the establishment of HLNP, local people destroyed forest and constructed sloping field to expand their cultivated area, however, this activity was totally banned after their living region belong to the national park in 2003. At present, local people still clear forest to increase their maize cultivated area but they destroy a small area step by step to avoid the investigation of Forest protection officers.

The household survey gave the results that more than more than $90 \%$ of total households sampled in HLNP grew maize, in which $100 \%$ of households sampled in the buffer zone grew maize. Although the maize cultivated area per household sampled in the buffer zone $($ Mean $=1559.94 \mathrm{~m} 2, \mathrm{SD}=1102.53)$ was higher than that one in the core zone $(\mathrm{Mean}=$ $1116.40 \mathrm{~m} 2, \mathrm{SD}=765.71$ ), there was no statistically significant difference between them. In average, each household in HLNP had 0.13 ha maize cultivated area (Mean $=1338.17$ $\mathrm{m} 2, \mathrm{SD}=967.31)$ (Table 6.4).

Table 6.4 Area of maize cultivated area of local people in HLNP

\begin{tabular}{|l|c|c|c|c|}
\hline Criteria & Core zone (N=30) & $\begin{array}{c}\text { Buffer zone } \\
(\mathrm{N}=30)\end{array}$ & Diff. & $\begin{array}{c}\text { Total } \\
(\mathrm{N}=60)\end{array}$ \\
\hline $\mathrm{N}$ & 25 & 30 & & 55 \\
$\%$ & 83.3 & 100 & & 91.7 \\
\hline Area per household (m2/hh) & & & & \\
Minimum - Maximum & $0-2500$ & $333-4995$ & & $0-4995$ \\
Mean (SD) & $1116(765)$ & $1559(1102)$ & n.s. & $1338(967)$ \\
\hline
\end{tabular}

Mann-Whitney U test, statistically significant at a 5\% level of error probability

Ethnic minorities group in both core zone and buffer zone of the national park planted both 
traditional and hybrid maize variety. Average of traditional maize variety area per household in the core zone was $266.40 \mathrm{~m} 2$ (SD = 562.67) which equaled to a half of average traditional maize variety area per household in the buffer zone (Mean $=590.52$, $\mathrm{SD}=1231.61)$. With regard to the hybrid maize variety, households in the core zone planted $850 \mathrm{~m} 2(\mathrm{SD}=852.48)$ and households in the buffer zone planted $969.43 \mathrm{~m} 2(\mathrm{SD}=$ 899.79). Over all, in average, households sampled in HLNP had $428.46 \mathrm{~m} 2$ (SD = 963.28) traditional maize variety and $909.72 \mathrm{~m} 2$ hybrid maize $(\mathrm{SD}=871.08)$.

Maize was used for home consumption and raising stock. It was not a cash crop in this region. Among 60 households sampled, only one respondent in Sin Chai village sold $50 \mathrm{~kg}$ maize dry seed to get cash income. However, this case was special because the respondents lived alone, did not cultivate rice but consumed rice of her son who stayed in another village. She slashed and burned a small area to cultivate maize for raising pigs to generate cash income in emergency case.

\subsubsection{Home-garden}

More than $90 \%$ households in both the core zone and the buffer zone of HLNP grew vegetable in small home garden adjacent to their house with relatively high biodiversity. There was a few of households having extremely big garden with the area in range from $2000 \mathrm{~m} 2$ to $4000 \mathrm{~m} 2$. They used a large portion of it for growing fruits and sweet potato or raising livestock. However, to protect these vegetables and spices from raising-free range chicken and pig, buffalo and goat, all these small gardens had fence.

Table 6.5: Area of home garden of local people in HLNP

\begin{tabular}{|l|c|c|c|}
\hline Criteria & Core zone $(\mathrm{N}=30)$ & Buffer zone $(\mathrm{N}=30)$ & Total $(\mathrm{N}=60)$ \\
\hline $\mathrm{N}$ & 29 & 27 & 56 \\
$\%$ & 96 & 90 & 93.3 \\
\hline Area of home garden $(\mathrm{m} 2 / \mathrm{hh})$ & & & \\
& & & \\
Minimum - Maximum & $0-4000$ & $0-600$ & $0-4000$ \\
Average (SD) & $411(792)$ & $162(184)$ & $287(583)$ \\
\hline
\end{tabular}

Area of home garden per capita in the core zone and the buffer zone was $54.75 \mathrm{~m} 2$ and $30.76 \mathrm{~m} 2$ respectively. Mann Whitney $U$ test applied to compare the average home garden area per capita of two zones did not show any statistically significantly difference (Table 6.2 in previous section)

Crops planted in home gardens are various including crops such as sweet potato, taro, potato, pumpkin, squash, canna, sugar cane, several kinds of bean and vegetables which are suitable for cold weather such as cabbage, kohlrabi, Brassica juncea (traditional vegetable), chayote (Sechium edule)... The spices such as ginger, garlic, onion, lesser galangal, chilies... are also planted as mix in the garden. Besides, Red Dao people in Ta Trung Ho village grow tea and some kinds of medical plants. Bathing with cooked watermedical plant is one tradition of Red Dao community in Sa Pa district. Fruit trees in home garden commonly are persimmon, peach and plum and banana. In some villages which scatter locates at low elevation, other fruits such as guava, papaya, jack fruit and papaya are also found. Fruit trees are grown on flat land or on slopes around the house. Beside vegetables and fruit tree, some households grow ornamental tree and flower such as rose, 
orchid in front of the house.

Home gardens are used primarily for home consumption and share to close relatives, not for selling. Some respondents in the buffer zone stated that they may sell some vegetables or fruits for some shops of Kinh people in the village if they have abundant amount, normally at full harvest time.

\subsection{Livestock system}

The survey gave the results that $100 \%$ of households sampled in both core zone and buffer zone raise livestock. Popular types of livestock raised in HLNP are chicken (90\% of total households sampled raise), local pig ( $88.33 \%$ of total households sampled raised, buffalo (56.66 \% of total households sampled raised) and duck (46.66\% of total households samples raised) (Table 6.6). Other kinds of livestock such as cow, goat and hybrid pig and musk duck was raised by a small number of households. There was very few households raised cow.

Between two zones, the number of households which raise big livestock (including buffalo, cow and goat), local pig and chicken was higher than it is in the buffer zone. It shows that raising livestock in the core zone is more popular than the buffer zone. Hybrid pig was raised in the buffer zone by $20 \%$ of total households sampled whereas no household in the core zone raise this kind of pig variety.

Table 6.6: Distribution of household sampled by livestock

\begin{tabular}{|l|c|c|c|c|c|c|}
\hline \multirow{2}{*}{ Livestock } & \multicolumn{2}{l|}{ Core zone (N=30) } & \multicolumn{2}{c|}{$\begin{array}{c}\text { Buffer zone } \\
(\mathrm{N}=30)\end{array}$} & \multicolumn{2}{c|}{ Total (N=60) } \\
\cline { 2 - 7 } & $\mathrm{N}$ & $\%$ & $\mathrm{~N}$ & $\%$ & $\mathrm{~N}$ & $\%$ \\
\hline Buffalo & 21 & 70 & 13 & 43.33 & 34 & 56.66 \\
\hline Cow & 5 & 16.67 & 0 & 0 & 5 & 8.33 \\
\hline Goat & 5 & 16.67 & 2 & 6.67 & 7 & 11.66 \\
\hline Local pig & 28 & 93.33 & 25 & 83.33 & 53 & 88.33 \\
\hline Hybrid pig & 0 & 0 & 6 & 20 & 6 & 10 \\
\hline Chicken & 28 & 93.33 & 26 & 86.66 & 54 & 90 \\
\hline Duck & 12 & 40 & 16 & 53.33 & 28 & 46.66 \\
\hline Musk duck & 6 & 20 & 3 & 10 & 9 & 15 \\
\hline $\begin{array}{l}\text { Raising big livestock } \\
\text { (buffalo, cow, goat) }\end{array}$ & 22 & 73.33 & 13 & 43.33 & 35 & 58.33 \\
\hline Raising pig & 28 & 93.33 & 28 & 93.33 & 56 & 93.33 \\
\hline $\begin{array}{l}\text { Raising poultry } \\
\text { (chicken, duck, musk duck) }\end{array}$ & 28 & 93.33 & 27 & 90 & 55 & 91.66 \\
\hline Raising livestock & 30 & 100 & 30 & 100 & 60 & 100 \\
\hline
\end{tabular}

Despite the fact that all household in HLNP raise animals, the number of animal was small (Table 6.7). Independent-samples $\mathrm{T}$ test was applied to compare the average number of 
each kind of livestock per household in two different zones of HLNP. The results indicated that there was no statistical significant difference between the average numbers of buffalo, local pig, and number of musk duck, total poultry and total pig. The number of chicken per household in the core zone was statistically significantly higher than the number of chicken per household in the buffer zone. The number of big livestock including buffalo, cow and goat in the core zone was also statistically significantly higher than the number of big livestock in the buffer zone.

Table 6.7: Average number of livestock in HLNP

\begin{tabular}{|c|c|c|c|c|}
\hline Livestock & Core zone & Buffer zone & Diff. & Total \\
\hline Buffalo & $\begin{array}{c}1.67(1.60) \\
0-7\end{array}$ & $\begin{array}{c}1.13(1.92) \\
0-8\end{array}$ & n.s. & $\begin{array}{c}1.40(1.77) \\
0-8\end{array}$ \\
\hline Cow & $\begin{array}{c}0.73(2.14) \\
0-10\end{array}$ & 0 & & $\begin{array}{c}0.37(1.55) \\
0-10\end{array}$ \\
\hline Goat & $\begin{array}{c}1.43(3.46) \\
0-10\end{array}$ & $\begin{array}{l}0.30(1.20) \\
0-6\end{array}$ & n.s. & $\begin{array}{l}0.87(2.63) \\
0-10\end{array}$ \\
\hline Local pig & $\begin{array}{c}4.30(3.63) \\
0-18\end{array}$ & $\begin{array}{c}3.33(2.74) \\
0-10\end{array}$ & n.s. & $\begin{array}{l}3.78(3.25) \\
0-18\end{array}$ \\
\hline Hybrid pig & 0 & $\begin{array}{c}1.80(5.65) \\
0-30\end{array}$ & & $\begin{array}{c}0.90(4.07) \\
0-30\end{array}$ \\
\hline Chicken & $\begin{array}{c}38.87(34.86) \\
0-150\end{array}$ & $\begin{array}{c}20.20(14.39) \\
0-50\end{array}$ & $*$ & $\begin{array}{c}29.53(28.06) \\
0-150\end{array}$ \\
\hline Duck & $\begin{array}{c}4.93(7.27) \\
0-30\end{array}$ & $\begin{array}{c}12.33(17.89) \\
0-60\end{array}$ & $*$ & $\begin{array}{c}8.63(14.04) \\
0-60\end{array}$ \\
\hline Musk duck & $\begin{array}{l}2.33(6.88) \\
0-35\end{array}$ & $\begin{array}{l}0.83(2.65) \\
0-10\end{array}$ & n.s. & $\begin{array}{l}1.58(5.22) \\
0-35\end{array}$ \\
\hline $\begin{array}{l}\text { Total big livestock } \\
\text { (buffalo, cow, goat) }\end{array}$ & $\begin{array}{c}3.83(5.29) \\
0-22\end{array}$ & $\begin{array}{c}1.43(2.43) \\
0-8\end{array}$ & $*$ & $\begin{array}{l}2.63(4.26) \\
0-22\end{array}$ \\
\hline Total pig & $\begin{array}{c}4.30(3.63) \\
0-18\end{array}$ & $\begin{array}{l}5.13(7.09) \\
0-40\end{array}$ & n.s. & $\begin{array}{l}4.68(5.62) \\
0-40\end{array}$ \\
\hline $\begin{array}{l}\text { Total poultry } \\
\text { (chicken, musk duck, duck) }\end{array}$ & $\begin{array}{c}45.80(38.94) \\
0-150\end{array}$ & $\begin{array}{c}33.37(23.79) \\
0-80\end{array}$ & n.s. & $\begin{array}{c}39.58(32.60) \\
0-150\end{array}$ \\
\hline
\end{tabular}

Notes: SD in parenthesis, Min - Max

Independent-samples $t$ test

Ethnic minority group has tradition of release buffalo and cow in the forest and they check their livestock one or two times per month which leads to the phenomenon of livestock death due to cold weather and lack of food on mountain in winter season. This free livestock rearing tradition still happens in some areas of HLNP. Among four selected village, local households in Ta Trung Ho village in the core zone grew a small area of grass to feed their livestock in shortage food season under the guidance of Forest Protection officers. 
In term of taking care of livestock, normally, during working days on the field, buffalo were feed grass and kept near the house at night time. On other days, they were kept far from the field by releasing in adjacent forest to avoid crop damage. After harvesting crops, local people released big livestock on the field for eating crop residues. Different from buffalo, goats were let free grazing near farmer's house from the morning and taken home in the evening. Other livestock such as pig, chickens, duck and musk duck was released around houses and fields, and maintained in fence at night time. Besides rice, maize and crop residues, local people went to forest to find edible plants for both their consumption and for their livestock.

With regard to production purpose, ethnic minority groups in HLNP used their livestock for home consumption more than for market. Big livestock such as buffalo and cow were raised to get draught power. Goat, pigs and chicken wre mostly raised for meat consumption, especially in special events such as wedding, funeral, New year holiday, harvest festival (Lễ cúng cơm lúa mới), praying for children and old people healthy, praying for diseased person get well recover... Problems in raising livestock included (i) buffaloes are dead due to cold weather and (ii) disease spread always happens in pig and poultry production. Among four selected villages, Giay ethnic people in Ta Van Giay 1 had highest frequency of selling livestock to get cash income in which selling pig was more popular. Raising pig for market started to become popular here. Throughout the PRA, it has been know that there are several households raised hybrid pigs in large scale in the village. They all had rice milling shop so that they could take the best use of rice husk and core of maize to produce mixed food for their livestock. In other village, selling livestock was not popular. It happens with households having high number of buffalo (such as more than 10 buffaloes) or households need cash in emergency case.

\subsection{Aquaculture}

Very few household had fishpond with small area represented in the range from $80 \mathrm{~m} 2$ to $400 \mathrm{~m} 2$ (Table 6.8). Due to cold weather of the region, variety of fish was limited and they easily died in winter. Main varieties are grass carp and common carp. Sometimes, local people feed the fish with vegetables and pig manure from pig pens constructed near the pond. These households harvested fish mostly for their home consumption and their relatives but it was even not enough, rarely sell to other people.

Table 6.8. Fishpond in HLNP

\begin{tabular}{|l|c|c|c|}
\hline Criteria & Core zone $(\mathrm{N}=30)$ & Buffer zone $(\mathrm{N}=30)$ & Total $(\mathrm{N}=60)$ \\
\hline $\mathrm{N}$ & 1 & 3 & 4 \\
$\%$ & $3.33 \%$ & $10 \%$ & $6.67 \%$ \\
\hline Area of fishpond (m2/hh) & & & \\
Minimum - Maximum & $0-100$ & $0-400$ & $0-400$ \\
Average (SD) & $13(73)$ & $9(28)$ & $11(55)$ \\
\hline
\end{tabular}

"Fish is not enough for home consumption. Some people came to buy, I did not want to sell, but they kept asking me because the fish taste good. I sold one or two times and earn a little money", Mr. M (supposed name, Ta Van Giay 1 village, The buffer zone of HLNP). "I earned only 300000 VND from fishpond because I sold only 2 or 3 fish". Mr. C (supposed name, Ta Van Giay 1 village, The buffer zone of HLNP". 


\section{Chapter 7}

\section{Forest based livelihood activities}

\subsection{Frequency of people going to forest}

Frequency of going to forest of local people in HLNP does not the same in one year. Households which plant cardamom go to their cardamom fields located deeply in the forest for checking time of harvest, then, labor force of those households go to forest for harvesting fresh cardamom fruits, trashing, weeding and drying them. During this season, these local people go to forest everyday if it's near their houses or stay continuously in forest until all fresh cardamom become dried.

In cardamom off season, households sampled going to forest with different frequency. The number of households which go to forest every day is low in all four villages. Most of Seo My Ty villagers access forest several times per week whereas Ta Trung Ho villagers access forest several times per month. In Sin Chai village, approximately a half of households sampled access forest several times per week and about $40 \%$ of households sampled go to forest several times per month. With regard to Ta Van Giay village, the number of households which access forest several times per month is equal to the number of households which access forest several times per year and each account for $46 \%$. Among whole samples, one household in Seo My Ty village did not go to forest in 2012 even for collecting firewood. Instead, this household drove boat and collected wood floating in the hydrological lake in Seo My Ty village after storm and flood. Among villages, Seo My Ty villagers have the highest frequency of forest access and it is followed by Sin Chai villagers, Ta Trung Ho villagers and Ta Van Giay 1 villagers respectively.

Table 7.1: Frequency of going to forest of local people off cardamom season in 2012

\begin{tabular}{|c|c|c|c|c|c|c|c|}
\hline \multirow{2}{*}{ Frequency } & \multicolumn{4}{|c|}{ Village } & \multirow{2}{*}{$\begin{array}{l}\text { Buffer zone } \\
\mathrm{N}(\%)\end{array}$} & \multirow{2}{*}{$\begin{array}{l}\text { Core zone } \\
\mathrm{N}(\%)\end{array}$} & \multirow{2}{*}{\begin{tabular}{|l|} 
Total \\
$\mathrm{N}(\%)$
\end{tabular}} \\
\hline & $\begin{array}{l}\text { Sin } \\
\text { Chai }\end{array}$ & $\begin{array}{l}\text { Ta Van } \\
\text { Giay1 }\end{array}$ & $\begin{array}{l}\text { Seo } \\
\text { My Ty }\end{array}$ & $\begin{array}{l}\text { Ta Trung } \\
\text { Ho }\end{array}$ & & & \\
\hline Everyday & 2 & 1 & 1 & 0 & $3(10)$ & $1(3.33)$ & $4(6.67)$ \\
\hline Several times per week & 7 & 0 & 11 & 1 & $7(23.33)$ & $12(40)$ & $19(31.67)$ \\
\hline Several times per month & 6 & 7 & 2 & 14 & $13(43.33)$ & $\begin{array}{l}16 \\
(53.33)\end{array}$ & $29(48.33)$ \\
\hline Several times per year & 0 & 7 & 0 & 0 & $7(23.33)$ & 0 & $7(11.67)$ \\
\hline No access forest & 0 & 0 & 1 & 0 & 0 & $1(3.33)$ & $1(1.67)$ \\
\hline Total & 15 & 15 & 15 & 15 & $30(100)$ & $30(100)$ & $60(100)$ \\
\hline
\end{tabular}

Between two zones, households in the core zone access forest more often than those living in the buffer zone. Overall, in off-season of rice and cardamom, approximately a half of total households sampled go to forest with frequency of several times per month and about $31 \%$ access forest with frequency of several per week. $6.67 \%$ of the whole samples go to forest everyday whereas $11.67 \%$ of households sampled rarely go to forest in one year. Households which do not go to forest accounts for $1.67 \%$ of total households sampled. 


\subsection{Firewood collection}

The household survey revealed that one hundred percent of households sampled collect firewood in HLNP for cooking, heating, pig-feed preparation and processing agricultural products at home and/or on the field. Households which cultivate rice, maize far from house collect firewood for using during their stay in small cottage near their fields. Similar, households which cultivate cardamom collect firewood for both drying cardamom and preparing food during harvest season. Cutting dead tree, diseased part of tree and collecting small dry branch for firewood is allowed in the HLNP. Almost households stated that they must go to forest to find firewood. In contrast, several households easily collect floating wood from stream near their cardamom fields because during storm dry branches are broken and float along water stream.

With regard to other kinds of energy, about $23 \%$ of the whole samples bought gas cooker and used gas along with fire wood (Table 6.2). These households located in both buffer zone and core zone of HLNP, including 5 Giay ethnic households in Ta Van Giay village and 9 Red Dan ethnic households in Ta Trung Ho village. Respondents stated that using gas along with firewood is convenient for food preparation to serve tourists/visitors and serve family members after hard-working days. In addition, several households providing home-stay services in Ta Van Giay village in the buffer zone buy fire wood for cooking because they do not have time to go to forest for collecting firewood. They must pay 5 million VND for one truck of firewood which could be used for several months. In the core zone, no household buy firewood.

Table 7.2: Energy use for cooking and heating of households sampled

\begin{tabular}{|l|c|c|c|c|c|c|}
\hline \multirow{2}{*}{ Criteria } & \multicolumn{2}{|c|}{ Core zone $(\mathrm{n}=30)$} & \multicolumn{2}{c|}{ Buffer zone $(\mathrm{n}=30)$} & \multicolumn{2}{c|}{ Total $(\mathrm{n}=60)$} \\
\cline { 2 - 7 } & $\mathrm{N}$ & $\%$ & $\mathrm{~N}$ & $\%$ & $\mathrm{~N}$ & $\%$ \\
\hline Firewood collection & 30 & 100 & 30 & 100 & 60 & 100 \\
\hline Using only firewood & 25 & 83.3 & 21 & 70 & 46 & 76.66 \\
\hline Using firewood and gas & 5 & 16.7 & 9 & 30 & 14 & 23.33 \\
\hline Buy firewood & 0 & 0 & 6 & 20 & 6 & 10 \\
\hline
\end{tabular}

Source: Field survey, 2013.

Approximately $77 \%$ of the whole sample use firewood as the only source of cooking energy. Firewood is available in HLNP and local people are allowed to extract them. With regard to season, local people go to forest more often to cut and save firewood for using in winter. Both men and woman participating in firewood collection, however, due to deforestation and high consumption need of large population, it takes local people longer time and longer trip to find fuel wood. With regard to purpose, one hundred percent of households use firewood for consumption only. There is not any household which sell firewood for cash income. The firewood which some other households buy are probably from adjacent areas of the HLNP.

\subsection{Timber extraction}

All households sampled in the HLNP extracts timber for home consumption purpose such as construction and repairing wooden house, kitchen, making wooden furniture, livestock pen, fence for home garden. They have no income generated from extracting timber in 
2012. Common timber species extracted by local inhabitants are Fokienia hodginsii (Po mu), Talauma gioi (Giổi), Madhuca subquincuncialis (Sến) and pine tree (Thông). Out of 60 households sampled, only one respondent which accounted for $1.67 \%$ extracted Fokienia hodginsii (Po mu) in 2012 for selling and get paid of 6 million VND for $2 \mathrm{~m} 3$. This household has poor certification.

Extracting timber for housing purpose is allowed in the HLNP. However, before extracting, households must follow paper work with different steps including asking permission from the village head, communal people committee and forest protection department. Due to complicated paperwork, local households often extract timber and prepare wood for housing construction without asking permission of involved stakeholders. Moreover, wood preparation may take long time. To have enough amount of timber, healthy male labors in the household must go to natural forest located deeply in the core zone of HLNP to find big tree. Then, they cut down the tree, divide in to different parts and carry home. This process may take several years and local people save timber adjacent to their house until they have enough necessary wood amount. In contrast, extracting timber for selling purpose is strictly prohibited in HLNP.

\subsection{NTFPs extraction}

NTFPs extraction is popular in HLNP, however, most of households participated in group discussion and household survey stated that forest resource including timber and NTFPs does not contribute in their annual cash income. They do not sell anything from forest because all extraction and selling are strictly prohibited by the state. Several households agreed that products extracted from forest contribute not much in their income. Table 7.3 shows kinds of NTFPs and utilization of local people in HLNP in 2012 based on responses of 60 households. NTFPs collected are diverse including material, food, livestock feed, ornamental and medical plant.

Bamboo and wild vegetables for livestock are two common NTFPs which local people in HLNP extract from forest for home use. About $90 \%$ of total respondents answered that they go to forest to collect banana, canna, fern... and prepare food for their pigs several times per week or per month depend on their free time. Bamboo is extracted in case local inhabitants need to build or repair livestock pen, making fence for their houses and gardens. Almost all households sampled extract bamboo for home use at least one time in 2012.

Mushroom and honey are collected by a small number of households, however, they use for home consumption but not for selling. Red Dao ethic group living in Ta Trung Ho village as well as other villages has tradition of bathing with medical plant for healthy. They often collect different kinds of medical plants in the forest and in their home garden, then cook with water and each member in the household will bath on same day. In case the households have guests, the guest is invited for bath first. Despite the fact that these medical plants are famous in Sapa town, all households sampled in Ta Trung Ho village stated that they collect these medical plants for home consumption only and sometimes send to relatives. No household get cash income from these bathing medical plants.

NTFPs which often bring cash income for local people include young bamboo shoot and some kinds of medicals. Young bamboo shoot is a popular food of local people living in mountainous areas of Vietnam. About $58 \%$ of total households sampled extract young bamboo shoot in HLNP and 10\% of total households sampled sell this kind of food for getting cash. Local people go to forest more often in young bamboo shoot season in 
September, October and January. With the price of $5000 \mathrm{VND} /$ bunch, households which sell young bamboo shoot could earn from 2 million to 4 million VND in one year depend on their extracted amount. Collecting fruits from Docynia indica also helps household earn cash income. This kind of fruit is famous for Sapa district. Only one household in Ta Trung Ho village among the whole samples collect and sell this kind of fruit. Participants of group discussion in Seo My Ty village stated that Docynia indica are available in their adjacent forest, never the less, Black H'mong from other villages often go to forest earlier and collect first.

Table 7.3: NTFPs extraction in HLNP in 2012.

\begin{tabular}{|c|c|c|c|c|c|c|c|}
\hline Kind of NTFPs & $\begin{array}{l}\text { Vietnamese } \\
\text { name }\end{array}$ & Use & $\begin{array}{l}\text { No of hh } \\
\text { extract }\end{array}$ & $\%$ & \begin{tabular}{|c|} 
No of \\
hh sell
\end{tabular} & $\%$ & $\begin{array}{l}\text { Selling price } \\
\text { (VND) }\end{array}$ \\
\hline Young bamboo shoot & Măng & Food & 35 & 58.3 & 6 & 10 & $5000 /$ bunch \\
\hline Mushroom & Nấm & Food & 3 & 5 & 0 & 0 & \\
\hline Honey & & Food & 2 & 3.3 & 0 & 0 & \\
\hline Docynia indica & Táo mèo & Medical & 1 & 1.7 & 1 & 1.7 & \\
\hline Morinda officinalis & Ba kích & Medical & 10 & 16.7 & 10 & 16.7 & $\begin{array}{l}\text { White tuber: } \\
20000 / \mathrm{kg} \\
\text { Purple tuber: } \\
80000 / \mathrm{kg}\end{array}$ \\
\hline $\begin{array}{l}\text { Gynostemma } \\
\text { pentaphyllum }\end{array}$ & Dảo cổ lam & Medical & 1 & 1.7 & 1 & 1.7 & $10000 / \mathrm{kg}$ \\
\hline $\begin{array}{l}\text { Orchid (including } \\
\text { different species) }\end{array}$ & Phong lan & Ornamental & 7 & 11.7 & 3 & 5 & $\begin{array}{l}70000 \rightarrow 200000 \\
/ \text { /orchid }\end{array}$ \\
\hline $\begin{array}{l}\text { Medical plants for } \\
\text { bathing of Red Dao } \\
\text { ethic group (include } \\
\text { different species) }\end{array}$ & $\begin{array}{l}\text { Lá thuốc tắm } \\
\text { của người } \\
\text { Dao Đỏ }\end{array}$ & Medical plant & 15 & 25 & 0 & 0 & \\
\hline Bamboo & Tre nứa & Material & 58 & 96.7 & 0 & 0 & \\
\hline $\begin{array}{l}\text { Wild vegetables } \\
\text { (banana, fern, ...) }\end{array}$ & Rau rừng & $\begin{array}{l}\text { Food and } \\
\text { pigfeed }\end{array}$ & 55 & 91.7 & 0 & 0 & \\
\hline
\end{tabular}

Morinda officinalis seems to be the common cash NTFPs product of local people in HLNP. It was collected by $16.7 \%$ of households in the HLNP. Black H'mong and Red Dao ethnic minority group collect it only for selling purpose. The price depends on each kind in which the purple tuber has higher price than the white one demonstrated by $80000 \mathrm{VND} / \mathrm{kg}$ versus $20000 \mathrm{VND} / \mathrm{kg}$ respectively. Gynostemma pentaphyllum is also collected for selling purpose; however, it's not common in HLNP. The households survey gave results that some households collect several tens kilos of Morinda officinalis per year which helps them earn from 1 million to several million VND.

With regard to ornamental, local people find orchid for both home use and market. There are different species with different kind of flowers. Price of orchid depend on the value of species and flower blooming period. Local people can sell orchid to local shops in their commune and/or Sapa town with good price, however, they have to go to evergreen forest which locate deeply in the core zone at high elevation, near the Pansipan Mount to find orchid due to deforestation and heavy exploitation. 
Both the household survey and group discussion gave results that poor households with limited livelihood activities and poor villages has higher dependence on NTFPs extraction than wealthy households. Among 16 household sampled having cash income from forest resources, 10 households have certification of poverty. With regard to ethnicity, households which extract NTFPs for cash income are primarily Black H'mong ethnic households from Seo My Ty village and Sin Chai village where poverty is high. Giay ethnic households in Ta Van Giay 1 village do not consider NTFPs as cash products. In Ta Trung Ho village, a few poor households collect NTFPs for selling. In general, forest resources extraction is affected by age, heath, livelihood activities and income diversification, unfortunate accidents during forest trip.

With regard to regulation, NTFPs collection is strictly prohibited in HLNP. However, most of respondents stated that they are allowed to extract young bamboo shoot, honey, medical plants in HLNP.

\section{Case study: Forest resources extraction}

Mr. S lives in Seo My Ty village in the core zone of HLNP. His household has 5 members including his spouse, three sons and they have received poor certification for 10 years. They do not possess any terrace and maize fields as well as cardamom plot. Before the hydrological lake and dam was established in Seo My Ty village, they stay in valley and have some paddy plots for rice plantation. However, their house and their fields were loss and they did not spend cash paid by the project on buying agricultural land like other households in the village. Besides rice cultivation in several paddy plots lend by relatives of his wife for 3 years which is about $40 \mathrm{~km}$ far from house, the respondent and his spouse go to forest approximately every day. He sells anything that he found and extracted from forests. In young bamboo shoot season, he and his wife go to forest very early and come back home in late afternoon. They always collect young bamboo shoot for 2 days and walk $12 \mathrm{~km}$ on path from Seo My Ty village to Ta Van Giay 1 village for selling to some local shops there with the price of $5000 \mathrm{VND} /$ bunch. In cardamom harvest season, they ask other villagers who have large cardamom area for off farm work such as weeding, harvesting and drying cardamom. In other periods, they go to forest to find mushroom, honey, wild tuber and medical plants such as Morinda officinalis, Gynostemma pentaphyllum, Docynia indica and sell in Sapa town. Their daily food often includes wild vegetables which they collect from forest. Cash income of this household is primarily from forest resource extraction (30\%) and off-farm job (60\%). He stated that forest extraction become more and more difficult nowadays. They have to go deeply and climb up to high mountains to find timber and NTFPs. Sometimes, for long trip, they bring rice with salt and stay overnight in the forest.

"We know Mr. S extract forest resources for selling but we let him do because his family is too poor. If not, they have nothing to eat. Before, Mr. S's parents were lazy and cultivated small paddy plots. If they worked hard, did shifting cultivation or planted cardamom to expand cultivated area before establishment of the national park, Mr. S would have agricultural land for planting rice and maize", said The village head and the leader of Forest Protection team of Seo My Ty village.

\subsection{Hunting and catching animals}

Participants in group discussion and most respondents in household survey said that they do not hunt or catch animals in HLNP because it's strictly prohibited in HLNP. Only three 
households said that they caught mouse and one household caught frog. During stay in cardamom fields for drying fresh cardamom fruit, local people catch mouse for eating if they see them. According to respondents, they can see mouse, bird and their livestock in the forest and rarely see big mammals. One respondent in Ta Trung Ho village stated that the last time he saw monkey and bear was after the big forest fire in 2011. Some kinds of animal were dead due to fire. Since then, he has not seen big mammals any more. Fish in the stream is reduced much due to construction of hydrological dam. Some households use small net to catch small fish in the stream, however, the amount which they catch per each time is enough for one meal only.

\subsection{Forest farming}

Forest farming in HLNP refers to to any crop cultivation, growing tree and livestock raising activity which occur in the boundary of HLNP. Agricultural activities such as cultivation of rice and maize, home garden with various kinds of plants and raising livestock were mentioned in the previous chapter of this thesis. In this section, cardamom cultivation will be considered. This kind of perennial plant cannot grow and development without removing forest soil ground layer, high elevation, soil moisture and forest canopy, therefore, it is arranged as forest based livelihood activity.

\subsubsection{Cardamom cultivation}

Cultivation of black cardamom (Amomum aromaticum) under forest canopy was encouraged in some provinces in the North of Vietnam after opium cultivation was banded in 1986. It is the important cash crop of local people living in HLNP, especially in the core zone of the national park. It had been considered as the "household insurance" of poor households due to their characteristics such as low input (plant one time but harvest for 10 to 15 years, no need to invest in fertilizer and pesticide or variety...) and high output price ( $1 \mathrm{~kg}$ of dry cardamom cost approximately 6USD in 2012).

Among three selected communes, Ta Van has the highest cardamom cultivated area with $502 \mathrm{ha}$, however, the lowest yield was found here demonstrated by $150 \mathrm{~kg}$ dried fruit/ha. In contrast, Ban Ho commune has a half cardamom cultivated area but the yield is double. With regard to the productivity and area per household, Ta Van has both the highest productivity and the highest cardamom cultivated area per household. It is followed by San Sa Ho commune and Ban Ho commune.

Table 7.4: Production of cardamom in three selected communes

\begin{tabular}{|l|c|c|c|}
\hline \multirow{2}{*}{ Criteria } & \multicolumn{3}{|c|}{ Commune } \\
\cline { 2 - 4 } & San Sa Ho & Ta Van & Ban Ho \\
\hline Total Area (ha) & 388 & 502 & 217 \\
\hline Yield (ton dried fruit/ha) & 0.2 & 0.15 & 0.3 \\
\hline Productivity (ton) & 54 & 67.5 & 44 \\
\hline
\end{tabular}

Source: Report of Social-economic of Communal People Committee in Sapa district, 2012

Cardamom is suitable to good forest condition, good moisture and elevation above $800 \mathrm{~m}$ a.s.l. Therefore, cardamom is suitable for grow and development in the core zone of HLNP. The number of Black H'mong and Red Dao ethnic group planting cardamom in the core zone accounts for $93 \%$ of households sampled in the core zone. In the buffer zone, $60 \%$ of 
households sampled which belongs primarily to Black H'mong ethnic group and a few Giay ethnic groups do this kind of forest farming. With regard to land use, share of cardamom area in total land use area of households sampled in the core zone was about $80 \%$ which is 1.7 times higher than that one in the buffer zone. For the whole samples, about $76 \%$ of households sampled grow cardamom and share of cardamom area in total land use area is $70 \%$ (Table 7.5 )

Table 7.5: Cardamom cultivation in HLNP

\begin{tabular}{|c|c|c|c|c|c|}
\hline Criteria & Measure & $\begin{array}{r}\text { Core zone } \\
(\mathrm{n}=30)\end{array}$ & $\begin{array}{r}\text { Buffer zone } \\
(\mathrm{n}=30)\end{array}$ & Diff. & $\begin{array}{r}\text { Total } \\
(\mathrm{n}=60)\end{array}$ \\
\hline No. of hhs grow cardamom & $\begin{array}{l}\mathrm{N} \\
\%\end{array}$ & $\begin{array}{r}28 \\
93.33\end{array}$ & $\begin{array}{l}18 \\
60\end{array}$ & & $\begin{array}{r}46 \\
76.66\end{array}$ \\
\hline $\begin{array}{l}\text { Ethnicity } \\
\text { Black H'mong } \\
\text { Red Dao } \\
\text { Giay }\end{array}$ & $\begin{array}{l}\mathrm{N} \\
\mathrm{N} \\
\mathrm{N}\end{array}$ & $\begin{array}{r}13 \\
15 \\
0\end{array}$ & $\begin{array}{r}16 \\
0 \\
2\end{array}$ & & $\begin{array}{r}29 \\
15 \\
2\end{array}$ \\
\hline Cardamom area/ hh (m2) & $\begin{array}{l}\text { Average } \\
\text { SD } \\
\% \text { of total land use }\end{array}$ & $\begin{array}{l}22233 \\
36225 \\
79.74\end{array}$ & $\begin{array}{r}4931 \\
6685 \\
45.79\end{array}$ & $*$ & $\begin{array}{r}13582 \\
27259 \\
70.28\end{array}$ \\
\hline Cardamom area/ capita $(\mathrm{m} 2)$ & $\begin{array}{l}\text { Average } \\
\text { SD }\end{array}$ & 3259 & 853 & $*$ & 2056 \\
\hline
\end{tabular}

* statistically significant at a 5\% level of error probability Man Whitney $U$ test

At household level, the cardamom area in the buffer zone is statistically significant lower than that of the core zone represented by 0.49 ha versus 2.2 ha respectively. The cardamom area per capita in the buffer zone is also statistically lower than that of the core zone ( 853 $\mathrm{m} 2 /$ capita in comparison with $3259 \mathrm{~m} 2 /$ capita, respectively) (Table 7.5).

\subsubsection{Economic efficiency of cardamom production in HLNP}

Table 7.6 shows comparison between cardamom cultivation and rice cultivation which are two dominant plants in HLNP based on estimation of family labor requirement, work, input cost, output price and economic efficiency per one hectare. It's clear to see that the biggest different in production of cardamom and rice is the cost of variety, fertilizer and pesticide. In order to plant cardamom, local people do not invest anything in variety, fertilizer and pesticide. In contrast, in hybrid rice cultivation, more than 7 million VND is used for purchasing seed variety, fertilizer and pesticide per one hectare. In cardamom production, labor force requirement is much lower than that one in rice production represented by 40 to 60 man-days versus 350 man-days. The gross income brought by two kinds of plants is quite similar to each other (24 million VND versus 23 million VND).

With regard to rice cultivation in the study area, most of local grow one crop season per year. Annual work for one crop season including land preparation, seed-ding, transplanting seedling, irrigation (ensure flooded condition), weed control, applying fertilizer and pesticide, harvesting, rice shredding, carrying rice seed home and drying under sunlight. 
Table 7.6: Compare economic efficiency of cardamom production and rice production in HLNP (calculation for 1 ha)

\begin{tabular}{|c|c|c|c|c|}
\hline & \multirow{2}{*}{$\begin{array}{c}\text { Cardamom (Perennial crop) } \\
\text { Cost }\end{array}$} & \multicolumn{3}{|c|}{ Hybrid rice (Annual crop) } \\
\hline & & $\begin{array}{l}\text { Amount } \\
(\mathrm{kg})\end{array}$ & $\begin{array}{c}\text { Price } \\
(\mathrm{VND} / \mathrm{kg})\end{array}$ & $\begin{array}{c}\text { Cost } \\
(\mathrm{VND})\end{array}$ \\
\hline Variety & $\begin{array}{l}\qquad 0 \\
\text { Most respondents mentioned that they asked } \\
\text { variety from relatives \& neighbors for the first } \\
\text { time. Then, they prepare variety by } \\
\text { themselves for planting new or replaced dead } \\
\text { plant in next seasons }\end{array}$ & 30 & 70000 & 2100000 \\
\hline $\begin{array}{l}\text { Fertilizer } \\
\text { a) Ure } \\
\text { b) NPK }\end{array}$ & $\begin{array}{l}10 \\
100 \% \text { respondents who plant cardamom stated } \\
\text { that they do not use any fertilizer }\end{array}$ & $\begin{array}{l}\text { a) } 225 \\
\text { b) } 600\end{array}$ & $\begin{array}{l}10000 \\
5000\end{array}$ & $\begin{array}{l}2250000 \\
3000000\end{array}$ \\
\hline Pesticide & $\begin{array}{l}\quad 0 \\
100 \% \text { respondents who plant cardamom stated } \\
\text { that they do not use any pesticide }\end{array}$ & & & 300000 \\
\hline Labor requirement & $\begin{array}{l}40 \rightarrow 60 \text { man-days/year } \\
\text { (average } 50 \text { man-days/year) }\end{array}$ & & 350 man-day & \\
\hline Crop yield & $\begin{array}{c}150 \rightarrow 300 \mathrm{~kg} \text { dried fruit* } \\
\text { (Average: } 200 \mathrm{~kg} \text { dried fruit/ha) }\end{array}$ & $\begin{array}{r}4500 \mathrm{~kg} \\
\quad(\mathrm{Av}\end{array}$ & $\begin{array}{l}\rightarrow 4700 \mathrm{~kg} \mathrm{~g} \\
\text { rage: } 4600 \mathrm{k}\end{array}$ & $\begin{array}{l}\text { grain/ha * } \\
\text { g/ha) }\end{array}$ \\
\hline Selling price & $120000 \mathrm{VND} / \mathrm{kg}^{* *}$ & & $5000 \mathrm{VND} / \mathrm{k}$ & \\
\hline Gross income & $24000000 \mathrm{VND}$ & & $000000 \mathrm{VN}$ & \\
\hline $\begin{array}{l}\text { Total cost (seed, } \\
\text { fertilizer, pesticide) }\end{array}$ & $0 \mathrm{VND}$ & & $650000 \mathrm{VN}$ & \\
\hline \multicolumn{5}{|c|}{ Suppose that the household does not hire any labor } \\
\hline Net income & $24000000 \mathrm{VND}$ & & $350000 \mathrm{VN}$ & \\
\hline $\begin{array}{l}\text { Net income per } \\
\text { family-labor day }\end{array}$ & $\begin{array}{l}80000 \mathrm{VND} \text { for the } 1 \text { st harvest, } \\
\text { then } 480000 \mathrm{VND}\end{array}$ & & $43000 \mathrm{VND}$ & \\
\hline \multicolumn{5}{|c|}{ Suppose that $80 \%$ is family labor and $20 \%$ is labor hired } \\
\hline Cost of hiring labor & $150000 \mathrm{VND} /$ day $* 10$ man-days & \multicolumn{3}{|c|}{$150000 \mathrm{VND} /$ day $* 70$ man-days } \\
\hline Net income & $22500000 \mathrm{VND}$ & \multicolumn{3}{|c|}{$4850000 \mathrm{VND}$} \\
\hline $\begin{array}{l}\text { Net income per } \\
\text { family-labor day }\end{array}$ & $562500 \mathrm{VND}$ & \multicolumn{3}{|c|}{$17000 \mathrm{VND}$} \\
\hline $\begin{array}{l}\text { Duration from } \\
\text { seeding to } \\
\text { harvesting }\end{array}$ & $\begin{array}{l}\qquad 5 \rightarrow 6 \text { years } \\
\text { then annual harvest in } 10 \text { to } 15 \text { years }\end{array}$ & \multicolumn{3}{|c|}{ One crop season per year } \\
\hline $\begin{array}{l}\text { Cost of variety, } \\
\text { fertilizer, pesticide } \\
\text { for the next crop } \\
\text { season }\end{array}$ & 0 & \multicolumn{3}{|c|}{$7650000 \mathrm{VND}}$. \\
\hline
\end{tabular}

* Data obtained from Annual Report of Communal people committee in 2012 of three selected communes.

** Price in 2012 from Field survey 2013. 
Requirement of labors in cardamom cultivation is much less than that one in paddy rice cultivation. It takes cardamom cultivators six years to have the 1st harvest. In the 1st year, work includes clearing ground cover of forest and propagation from seed. In the 2nd and 3rd year, work includes weeding, trashing and transplanting 3-year old cardamom plant under forest canopy with spacing $3 \mathrm{~m} \times 3 \mathrm{~m}$. In the 4th and 5 th year, work includes weeding and trashing. In the 6th year, local can harvest the 1st time. Then, annual work includes weed control, trashing, harvesting, drying fresh fruit on the field after harvesting using firewood and carrying dried fruit home.

In case labors are family members, the net income of cardamom cultivation is much higher than the net income of rice cultivation due to extremely low cost for agricultural input in cardamom production. With regard to net income per man-day, rice production gives households sampled in the HLNP only 43000 VND (about 2 USD) per man-day as the consequence of cost of variety, fertilizer and pesticide. This result is similar to finding of CASRAD (2008) on economic efficiency of rice production in Bac Kan province in Northeast Vietnam where some ethnic groups such as Tay, Dao and H'mong stay (43 000 VND in our study versus $40000 \mathrm{VND}$ ). Cardamom production gives farmer $480000 \mathrm{VND}$ per man-day (23 USD/ man-day) which is approximately 10 times higher than rice cultivation. However, cardamom is a perennial crop and the 1st harvest is at 6 years after seeding. Therefore, it is necessary to accumulate family labor cost for 6 years of plantation in calculate the net income per man-day in the 1st harvest. Assume that one household spend 50 man-day per year in production of 1 ha cardamom harvested area, the net income per man-day will be 80000 VND (about 4 USD) which is approximately double net income brought by hybrid rice cultivation. From the second harvest, net income per man day will be around 480000 VND depending on the fluctuation of cardamom market.

In case the households hire labor, for example the amount of labor hired is $20 \%$ of total labor requirement and the price of wage labor at planting season or harvesting season is about $150000 \mathrm{VND} /$ day (130 $000 \mathrm{VND}$ /day plus lunch). The net cash income generated from cardamom cultivation is about 4 times higher than the net income generated from rice cultivation. The net income per family-labor-day generated from cardamom cultivation is about 30 times higher than that one from rice cultivation.

\subsubsection{Processing cardamom}

Cardamom is planted under forest canopy which is always far from house and walking is the main kind of transportation. Time of walking from respondent's houses to cardamom field is in range from 1 hour to 1 day. Therefore, local people often dry cardamom in the field using firewood to reduce weight with the conversion ratio from fresh to dried is in range from 3 to 3.5 times. In other words, $100 \mathrm{~kg}$ fresh fruit is converted to $30 \mathrm{~kg}$ dried fruit after processing. $100 \%$ households sampled which plant cardamom collect forest in HLNP for drying cardamom. Among 46 cardamom cultivators in our study, three households carry some fresh cardamom home for drying because the amount of cardamom fresh fruit in their fields is small (lower than 100kg fresh fruit). Normally, each household has several cardamom plots. If their plots are close, they will carry cardamom from the small plot to the bigger plot and drying there. In case the small plot is far from other plots, they carry cardamom home for selling fresh fruit directly or selling dried fruit after processing. Two households among 46 households planting cardamom sell a small part of their cardamom output under fresh fruit condition. Other household sampled left sell dried cardamom capsule only. 
During the field survey, most respondents in Sin Chai village and Seo My Ty village could not estimate the amount of firewood which they use for processing cardamom. Some others who locate primarily in Ta Trung Ho village gave different estimations such as 1 $\mathrm{m} 3 / 100 \mathrm{~kg}$ dried fruit (one respondent in Seo My Ty village and one respondent in Ta Trung Ho village), $1 \mathrm{~m} 3$ wood/ $150 \mathrm{~kg}$ dried cardamom (two respondents in Ta Trung Ho village), $1 \mathrm{~m} 3$ wood/ $400 \mathrm{~kg}$ dried cardamom (one respondent in Ta Trung Ho village), $1 \mathrm{~m} 3$ wood / $100 \mathrm{~kg}$ to $200 \mathrm{~kg}$ dried cardamom (one respondent in Ta Trung Ho village), $1 \mathrm{~m} 3$ wood/ 1 ton dried cardamom (two respondents in Ta Trung Ho village), $1 \mathrm{~m} 3$ wood/ 300 to $400 \mathrm{~kg}$ dried cardamom). According to these estimations, overall, cardamom cultivator need $1 \mathrm{~m} 3$ of wood to dry $1200 \mathrm{~kg}$ of fresh cardamom to get $360 \mathrm{~kg}$ dried capsule at average.

\subsubsection{Possibility of expanding cardamom cultivation in the HLNP}

During the household survey, cardamom cultivators were asked whether they intend to grow cardamom next year. All cardamom cultivators stated that they would like to grow more cardamom to get more cash income like other households in the village, however, at present the natural forest inside the HLNP is approximately full of cardamom and there is limited suitable area left for them to plant that spice. Among 46 households doing forest farming, 30\% would plant new cardamom in 2014 nearby their current cardamom fields. The area of new cardamom would be in range from 0.2 ha (corresponding to 200 cardamom plants) to 3 ha (corresponding to 3000 cardamom plants). $70 \%$ remaining stated that they will not plant new cardamom in 2014 due to unavailability of forested land area which is suitable for this kind of spice. They would replace dead plants in their current fields.

\subsection{Participation of local people in forest protection}

$100 \%$ of total respondents stated that forest protection is necessary; however, responses were various when the researcher asked about reason. $10 \%$ gave no reason for forest protection. $50 \%$ of the whole samples mentioned only the provision ecosystem services of forest which is providing human with firewood, wild vegetables and medical plants... 16/6\% of total respondents mentioned the provision ecosystem service and the function of preserving water, reducing flood of the forest. One respondent corresponding to $1.66 \%$ mentioned the windbreak function of the forest. Wind in February is very strong and house roof of local people are broken. It is said that "Yellow fly, dog flea, Than Uyen wind" in Northern Vietnam to describe the threats of these factors to people including strong wind of Than Uyen region. 1.66\% remaining mentioned the forest resources (plants and animals) and happiness when he hears bird singing in the forest as the reason for forest protection.

With regard to activities to protect forest, $80 \%$ of total household heads revealed that they often participated in tree plantation and prevent/rescue forest fire in which $40 \%$ is willing to do because forest is important, $3.33 \%$ participate because they have responsibility to do it before local residents; $17.67 \%$ participate because they are asked by local authority and $20 \%$ participate because they are afraid that their cardamom fields are burned. $20 \%$ remaining sometimes participate in forest protection activities. Their reasons are they live far from the village centre and are not asked by village head to go for rescue forest fire, they're not available in the region when forest fire happens; forest fire does not happen in forest nearby their village and they will participate in tree plantation if the village head inform them. 


\section{Chapter 8}

\section{Contribution of cardamom to livelihood of local people}

\subsection{Income diversification of local people in HLNP differentiated by zone}

Table 8.1 lists all cash income source of households sampled and Simpson Index of Diversity of cash income (SID) in two zones of HLNP. It is easy to see that cash income share from cardamom in both zones are the highest among all cash income sources represented by $77.89 \%$ in the core zone and $38.42 \%$ in the buffer zone. To the whole samples, cardamom contributes $58.15 \%$ to household's cash income. With highest share in cash income of households sampled, it could be concluded that households in HLNP are highly dependent on forest farming or cardamom cultivation. It is the most important cash income source of local people whereas other crops such as rice, maize and vegetable brings very little cash income for HLNP villagers represented by $0.18 \%$. Thus, it could be assumed that local people's subsistence depend totally on their annual crops production while their cash income are obtained from forest farming.

Table 8.1 Cash income sources of local people in HLNP differentiated by zone

\begin{tabular}{|c|c|c|c|}
\hline & Core zone $(\mathrm{N}=30)$ & Buffer zone $(\mathrm{N}=30)$ & Total $(\mathrm{N}=60)$ \\
\hline \multicolumn{4}{|c|}{ Estimated cash income share from farm activities in $2012(\%)$} \\
\hline $\begin{array}{l}\text { Rice, maize and vegetables } \\
\text { Livestock }\end{array}$ & $\begin{array}{l}0 \\
3.16\end{array}$ & $\begin{array}{l}0.37 \\
8.80\end{array}$ & $\begin{array}{l}0.18 \\
5.98\end{array}$ \\
\hline \multicolumn{4}{|c|}{ Estimated cash income share from forest-based livelihood activities in 2012 (\%) } \\
\hline Timber and NTFPs & 4.37 & 10.73 & 7.55 \\
\hline \multicolumn{4}{|c|}{ Estimated cash income share from cardamom in $2012(\%)$} \\
\hline & 77.89 & 38.42 & 58.15 \\
\hline \multicolumn{4}{|c|}{ Estimated cash income share from tourism-based livelihood activities in 2012 (\%) } \\
\hline & 0.40 & 14.14 & 7.27 \\
\hline \multicolumn{4}{|c|}{ Estimated cash income share from other sources of income in $2012(\%)$} \\
\hline $\begin{array}{l}\text { Salary } \\
\text { Wage labor } \\
\text { Lend house } \\
\text { Self employment (milling shop, carpenter) } \\
\text { Ornamental } \\
\text { Remittance }\end{array}$ & \begin{tabular}{|l|l}
0.79 \\
9.21 \\
0 \\
4.14 \\
0 \\
0
\end{tabular} & $\begin{array}{l}8.03 \\
6.86 \\
0.64 \\
9.71 \\
0.71 \\
1.54\end{array}$ & $\begin{array}{l}4.41 \\
8.04 \\
0.32 \\
6.92 \\
0.35 \\
0.77\end{array}$ \\
\hline $\begin{array}{l}\text { Simpson Index of cash income sources } \\
\text { Min-Max }\end{array}$ & $\begin{array}{l}\mathbf{0 . 2 0} \mathbf{a} \\
0-0.65\end{array}$ & $\begin{array}{l}\mathbf{0 . 3 2} \mathbf{b} \\
0-0.77\end{array}$ & $\begin{array}{l}0.26 \\
0-0.77\end{array}$ \\
\hline
\end{tabular}

Independent samples t test for Simpson Index of cash income sources, 5\% level of error probability 
The second important source of cash income in HLNP is wage labor with the cash income share of $8.04 \%$ and it is followed by the forest resource extraction including timber and NTFPs with the cash income share of $7.55 \%$. Tourism based livelihood including various activities such as providing home-stay service, selling handicraft products for visitors... contributes $7.27 \%$ to total cash income of households. Self-employment such as household has rice milling shop or respondents work as carpenter and construction worker contribute $6.92 \%$ of total cash income. Livestock is the next important cash income sources with the share of $5.98 \%$ which showed that local people consume livestock more than selling. Other sources of income such as salary, ornamental, remittance share small portion of total cash income. In fact, there is a few households having these kinds of cash income sources.

Table 8.1 also showed that the importance of each cash income source to households in the core zone and buffer zone is different from each other. In details, cash income share of cardamom in the core zone is approximately double its share in the buffer zone. On the contrary, income share from livestock, forest resources (timber and NTFPs) and selfemployment in total cash income in the buffer zone are about two times higher than their share in the core zone. It is possible to construct a rank of these different cash income sources of two zones based on their cash income share from 1 to 11 in which 1 means the most important cash income source and importance reduces when it increases from 1 to 11 (Table 9.2).

Table 8.2 Rank of importance of income source of local people in two zones of HLNP

\begin{tabular}{|l|c|c|c|c|c|c|c|c|c|c|c|}
\hline & \multicolumn{9}{c|}{ Sources of cash income } \\
\cline { 2 - 12 } & Cardamom & $\begin{array}{l}\text { Wage } \\
\text { labor }\end{array}$ & $\begin{array}{l}\text { Forest } \\
\text { resource }\end{array}$ & $\begin{array}{l}\text { Self em- } \\
\text { ployment }\end{array}$ & $\begin{array}{l}\text { Live- } \\
\text { stock }\end{array}$ & Salary & Tourism & $\begin{array}{l}\text { Remmit- } \\
\text { ance }\end{array}$ & $\begin{array}{l}\text { Ornam- } \\
\text { ental }\end{array}$ & $\begin{array}{l}\text { Lend } \\
\text { house }\end{array}$ & $\begin{array}{l}\text { Annual } \\
\text { crops }\end{array}$ \\
\hline $\begin{array}{l}\text { Core } \\
\text { zone }\end{array}$ & 1 & 2 & 3 & 4 & 5 & 6 & 7 & - & - & - & - \\
\hline $\begin{array}{l}\text { Buffer } \\
\text { zone }\end{array}$ & 1 & 7 & 3 & 4 & 5 & 6 & 2 & 8 & 9 & 10 & 11 \\
\hline
\end{tabular}

Despite different cash income share, households sampled in two zones have some similar characteristics in rank of cash income sources represented by the same rank of cardamom source, forest resources, self-employment, livestock and salary. Wage labor is the second important source of cash income in the core zone with share of $9.21 \%$, however, in the buffer zone, income share from this activity was $6.86 \%$ and rank the importance of 7 among all cash income source. In contrast, tourism based livelihood activities is the second importance cash income source in the buffer zone with the contribution of $14.14 \%$, but in the core zone, its rank is 7 with the very small cash income share of $0.40 \%$. Four sources of cash income which are remittance, ornamental, annual crops (rice, maize, vegetables) and lend house contribute from $0.3 \%$ to $1.5 \%$ of total cash income of households sampled in the buffer zone, however, in the core zone, local people have not earn any cash income from these sources.

Considering all sources of cash income, the Simpson Diversity Index of cash income sources in the core zone is lower than that one in the buffer zone $(0.20$ versus 0.32 , respectively), the difference is statistically significant at $\mathrm{P}<0.05$. $(\mathrm{t}(58)=2.096, \mathrm{p}=0.04)$. Simpson Diversity index of the whole sample was 0.26 which shows that income diversification in HLNP is low. 
Cardamom brings the highest cash income for households in both core zone and buffer zone of HLNP. According to results above, if cardamom cultivation is banned in HLNP, local households will lose their highest cash income share which is $77.89 \%$ in the core zone and $38.42 \%$ in the buffer zone, respectively.

However, findings above are calculated in average of each zone in the whole samples and of the whole samples. Livelihood strategies and income diversification of households sampled are not similar. In order to identify economic loss of local people in case the government bans cardamom cultivation in HLNP, it is required to identify different types of households and economic loss will be estimated according to characteristics of each household groups. Identifying household typology could be conducted based on several criteria, for example land endowment, cardamom cultivated area, total net income, contribution of cardamom in total net income, distance to market... Households with different farm size, different cardamom cultivated area, different livelihood activities which bring them cash and in-kinds will face different risks, difficulties if cardamom cultivation is banned in HLNP. Thus, they will have different coping strategies. The simplest example is that households which do not involve in cardamom cultivation or any activity relevant to cardamom will not be affected when the government bans this kind of forest farming. In contrast, households which are primarily dependent on cardamom cultivation or temporal wage related to cardamom will have a shock when they cannot earn cash income from this source any more. Moreover, they will face difficulties and risks when they find replaceable livelihood activity and start doing it. This kind of shock in mountainous areas where inhabitants are primarily ethnic minority groups with limited education, literacy and information may negatively affect the farm household in long time.

\subsection{Households typology}

Among 60 households sampled, there were 46 households grow cardamom which accounted for $76.66 \%$ of total households. 14 households corresponding to $23.33 \%$ of total households sampled do not involve in forest farming, therefore, it could be concluded that these households will not be affected if cardamom cultivation in HLNP is banned. Thus, identifying household typology will be conducted in category of cardamom cultivators and non-cardamom cultivators. Based on that, the researcher could identify not only the contribution of cardamom to livelihood of local people and their economic loss when this forest farming is banned but also differences in characteristic in farming system and livelihood strategies among small clusters in each category.

\section{Households typology of Cardamom cultivation group}

Identifying household typology was conducted based on Principal Components Analysis (PCA) and Cluster analysis (CA). Twenty variables would be included in PCA was presented in the Table 9.3. They contain information related to household such as location in HLNP, demographic characteristics, land allocation, livestock raising activities and generating income activities of households. Share of forest extraction activities in total net cash income were choose because it helps identifying forest-based livelihood activities of households sampled. Tourism share in total net cash income was chosen to have an over view about current participation in tourism of cardamom cultivators.

It is necessary to check whether these twenty variables and the data set of the whole samples with 46 households could be combined in some way which help reduce the set of variables or not. KMO test gave the result of $0.586(>0.5)$ which was an acceptable value 
according to Kaiser (1974). Barnett's Sphericity test gave highly significance value ( $\mathrm{p}<$ 0.001). Therefore, factor analysis is appropriate in our case and twenty original variables can be combined to form new variables (also call components or factors)

Table 8.3 Descriptions and summary statistics of variables using in PCA

\begin{tabular}{|c|c|c|c|c|}
\hline & Variables & Description & Mean & SD \\
\hline $\begin{array}{l}1 \\
2 \\
3 \\
4\end{array}$ & $\begin{array}{l}\text { Household } \\
\text { Age } \\
\text { Year schooling } \\
\text { Household size } \\
\text { Labor }\end{array}$ & $\begin{array}{l}=\text { Age of household head } \\
=\text { No. of years the household head attended school } \\
=\text { No of household member } \\
=\text { No. of labors in the household }\end{array}$ & $\begin{array}{r}40.18 \\
3.12 \\
6.17 \\
3.32\end{array}$ & $\begin{array}{r}10.81 \\
3.44 \\
2.59 \\
1.62\end{array}$ \\
\hline 5 & $\begin{array}{l}\text { Distance to closest } \\
\text { agricultural input shop }\end{array}$ & $\begin{array}{l}=\text { Distance from the house to the closest agricultural } \\
\text { input shop where fertilizer, seed, pesticide are sold } \\
(\mathrm{km})\end{array}$ & 7.62 & 4.39 \\
\hline 6 & Distance to Sapa town & $=$ Distance from the house to Sapa town $(\mathrm{km})$ & 17.34 & 11.31 \\
\hline $\begin{array}{l}7 \\
8 \\
9 \\
10\end{array}$ & $\begin{array}{l}\text { Land } \\
\text { Rice area } \\
\text { Cardamom area } \\
\text { Per-capita cardamom area } \\
\text { Total land use area }\end{array}$ & $\begin{array}{l}=\text { Rice cultivated area of household }(\mathrm{m} 2) \\
=\text { Area of cardamom under forest canopy (m2) } \\
=\text { Area of cardamom per household member (m2) } \\
=\text { Total land use area of household (included } \\
\text { cardamom cultivated area under forest canopy) (m2) }\end{array}$ & $\begin{array}{r}3976 \\
13582 \\
2056 \\
19515\end{array}$ & $\begin{array}{r}2810 \\
27259 \\
3156 \\
29810\end{array}$ \\
\hline $\begin{array}{l}11 \\
12 \\
13 \\
14\end{array}$ & $\begin{array}{l}\text { Live stock } \\
\text { Total big livestock } \\
\text { Total poultry } \\
\text { Hybrid pig } \\
\text { Local pig }\end{array}$ & $\begin{array}{l}=\text { Total number of buffalo, cow and goat } \\
=\text { Total number of chicken, duck, musk duck } \\
=\text { Number of hybrid pig } \\
=\text { Number of traditional pig }\end{array}$ & $\begin{array}{r}2.63 \\
39.58 \\
0.90 \\
3.82\end{array}$ & $\begin{array}{r}4.26 \\
32.60 \\
4.07 \\
3.22\end{array}$ \\
\hline $\begin{array}{l}15 \\
16\end{array}$ & $\begin{array}{l}\text { Income } \\
\text { Total net cash income } \\
\text { Per-capita net cash } \\
\text { income }\end{array}$ & $\begin{array}{l}=\text { Total net cash income of household (000 VND) } \\
=\text { Net cash income per household member per year } \\
(000 \text { VND) }\end{array}$ & $\begin{array}{r}52103 \\
8797\end{array}$ & $\begin{array}{l}66767 \\
10490\end{array}$ \\
\hline $\begin{array}{l}17 \\
18 \\
19 \\
20\end{array}$ & $\begin{array}{l}\text { Income diversification } \\
\text { Simpson Diversity Index } \\
\text { Cardamom cash share } \\
\text { Tourism cash share } \\
\text { TimberNTFPs cash share }\end{array}$ & $\begin{array}{l}=\text { Simpson Diversity Index of cash income sources } \\
=\text { Share of cardamom in total net cash income }(\%) \\
=\text { Share of tourism in total net cash income }(\%) \\
=\text { Share of forest resources extraction in total net } \\
\text { cash income }(\%)\end{array}$ & $\begin{array}{r}0.26 \\
58.15 \\
2.12 \\
7.55\end{array}$ & $\begin{array}{r}0.22 \\
40.63 \\
10.12 \\
18.51\end{array}$ \\
\hline
\end{tabular}

\begin{tabular}{|lll|}
\hline \multicolumn{3}{|c|}{ KMO and Bartlett's Test } \\
\cline { 1 - 2 } Kaiser-Meyer-Olkin Measure of Sampling Adequacy. & .586 \\
Bartlett's Test of & Approx. Chi-Square & 1045.984 \\
Sphericity & df & 190 \\
& Sig. & .000 \\
\hline
\end{tabular}




\section{Principal components analysis result}

Principal component analysis gave the result of 6 new components with eigenvalues greater than 1 (Table 8.4). Identifying new components could be conducted based on the relationship of each component with original variables as well as their contribution in explaining variability.

With $28.57 \%$ of variance explain, the first component explained larger amount of variance than all five other components. This component show positive correlations to cardamom cultivation, rice cultivated area, net cash income, and livestock including poultry and local pig. Households with larger cardamom cultivated area will have higher cash income, large rice area and raise more small animals.

Table 8.4 Six components resulting from PCA with loadings for twenty original variables (only loadings higher than 0.4 was shown).

Rotated Component Matrix ${ }^{a}$

\begin{tabular}{|c|c|c|c|c|c|c|}
\hline & \multicolumn{6}{|c|}{ Component } \\
\hline & 1 & 2 & 3 & 4 & 5 & 6 \\
\hline $\begin{array}{l}\text { area_harvested_cardamo } \\
\mathrm{m}\end{array}$ & .950 & & & & & \\
\hline $\begin{array}{l}\text { per_capita_cardamom_ } \\
\text { areā }\end{array}$ & .948 & & & & & \\
\hline $\begin{array}{l}\text { Total_area_include_ } \\
\text { Cardāmom- }\end{array}$ & .944 & & & & & \\
\hline Total_net_income & .942 & & & & & \\
\hline Capita_Net_income_year & .933 & & & & & \\
\hline Local_pig & .684 & & & & & \\
\hline total_poultry & .656 & & & .535 & & \\
\hline no_labor & & .830 & & & & \\
\hline no_hh_member & & .827 & & & & \\
\hline age & & .730 & & & & \\
\hline area_rice & .415 & .630 & & & & \\
\hline year_schooling & & -.629 & & & & \\
\hline hybrid_pig & & & -.815 & & & \\
\hline $\begin{array}{l}\text { disstance_agriculture_- } \\
\text { input }\end{array}$ & & & .742 & & & \\
\hline disstance_sapa_town & & & .566 & & & \\
\hline total_big_livestock & & & & .802 & & \\
\hline Simpson_index & & & & .639 & -.416 & \\
\hline timber_NTFPs_share & & & & & -.925 & \\
\hline Cardamom_cash_share & & & & & .605 & -.493 \\
\hline Tourism_cash_share & & & & & & .897 \\
\hline
\end{tabular}

\begin{tabular}{|l|c|c|c|c|c|c|}
\hline Eigenvalues & 6.533 & 2.973 & 2.381 & 1.643 & 1.258 & 1.063 \\
\hline Explained variance (\%) & 28.57 & 15.02 & 10.23 & 9.09 & 8.50 & 7.83 \\
\hline $\begin{array}{l}\text { Cumulative explained } \\
\text { variance (\%) }\end{array}$ & 28.57 & 43.59 & 53.82 & 62.91 & 71.42 & 79.25 \\
\hline
\end{tabular}


The second component explains $15.02 \%$ of variance. It has positive relations to household characteristics including household size, number of labor, age of household head, and rice cultivated area. It also shows the negative correlation with the time attended school of household head. Households with low education tend to have large household size, more labors and grow more rice to meet the need of home consumption.

The third component which explains $10.23 \%$ of variance shows positive correlation with distance from household to the closest agricultural inputs provider and distance from house to Sapa town. Besides, this component has negative relation with hybrid pig variables. In other words, households located far from the agricultural inputs source and Sapa town in general or households located in core zone of HLNP raise fewer hybrid pigs.

The next component (Component 4) which explained $9.09 \%$ of variance is positively correlated with Simpson Diversity Index of cash income sources, total poultry and total cattle. It possibly means that households have many livestock tend to sell their livestock to get cash and diversify their income.

Component 5 which explained $8.50 \%$ of variance shows negative correlation with Simpson Diversity Index of cash income source and share of forest resources extraction in total net cash income. It also has positive correlation with share of cardamom in total net cash income, meaning that households strongly do forest farming will less participate in extracting timber and NTFPs for selling and it reduces their income diversification.

With $7.83 \%$ explained variance, the last component (Component 6) has negative relationship with share of cardamom in total net cash income but shows positive correlation with share of tourism in total net cash income. It could be understand that households with high earning from cardamom will have low cash income from tourism activities such as doing home stay services, selling handicrafts...

\section{Cluster analysis results}

Hierarchical Cluster Analysis was conducted using six components in which Ward's method with interval of Euclidean distance were used. As a result, the dendogram (Figure 8.1) shows the combination of different households in clusters and the distance level at which combination exists among farm households and clusters. 


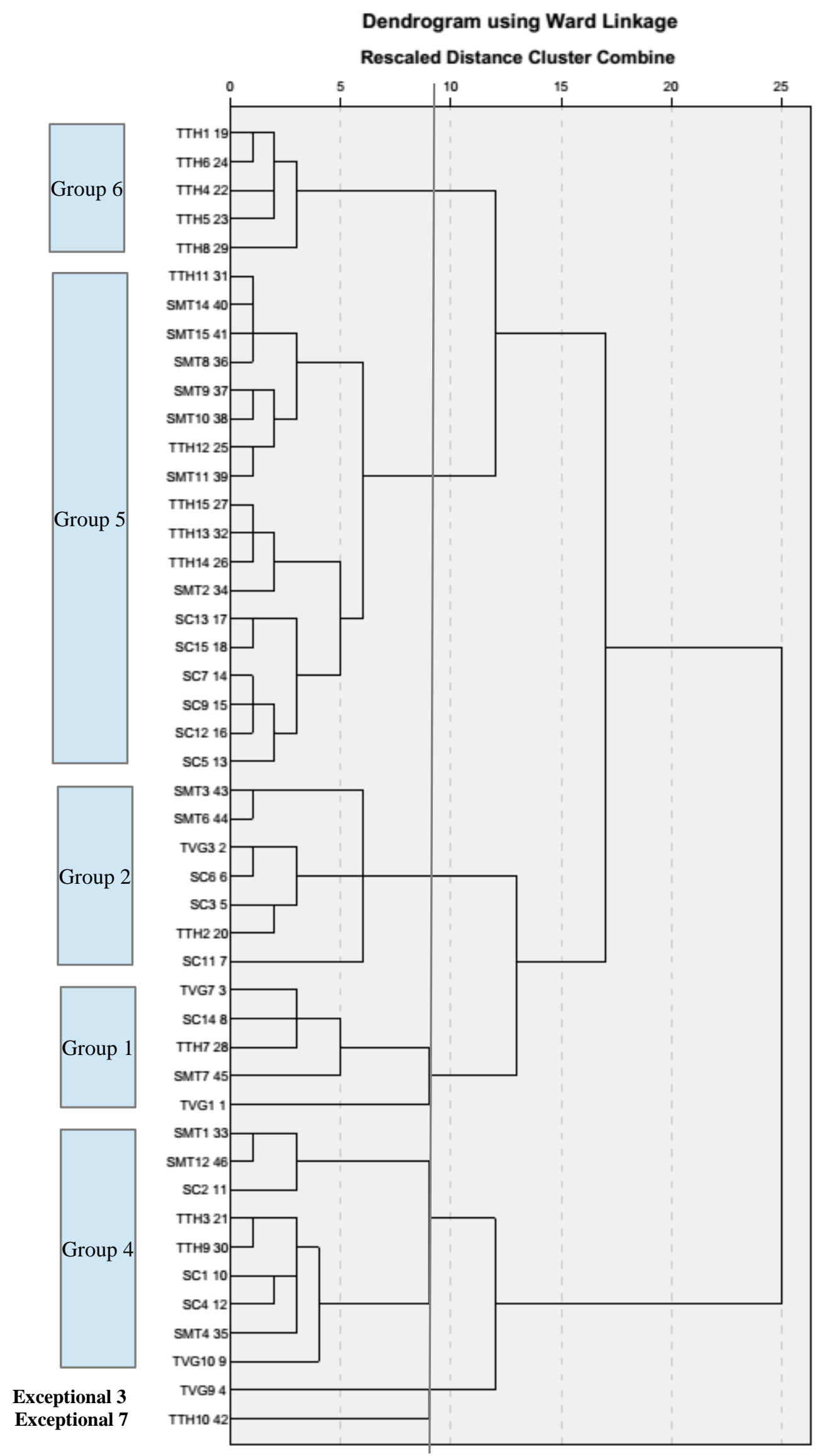

Figure 8.1: Dendogram resulting from Ward's method of cluster analysis. 46 households with code were represented on the Y axis. (SC: Sin Chai village, SMT: Seo My Ty village; TTH: Ta Trung Ho village; TVG: Ta Van Giay village) 
Among seven clusters formed, there were two clusters (Cluster 3 and 7) with frequency equal 1 . They could be considered as exceptional cases because they represent a small part of the whole population. Five other clusters represent five typological household groups with different characteristics in land endowment, livelihood strategies and cardamom share (Table 8.5). Based on that, it is possible to estimate the economic loss when cardamom cultivation is forced to stop by state power and identify which group is the most vulnerable.

Table 8.5: Farm household's main characteristics

\begin{tabular}{|c|c|c|c|c|c|c|c|c|}
\hline Criteria & $\begin{array}{c}\text { Group } 1 \\
\text { Rich } \\
\text { cardamom } \\
\text { and } \\
\text { livestock, } \\
\text { diverse } \\
\text { income } \\
\text { sources }\end{array}$ & $\begin{array}{c}\text { Group 2 } \\
\text { Poor hh } \\
\text { with land } \\
\text { scarce, } \\
\text { strong } \\
\text { forest } \\
\text { resource } \\
\text { extraction }\end{array}$ & $\begin{array}{l}\text { Cluster } 3 \\
\text { Land scarce, } \\
\text { strong } \\
\text { tourism- } \\
\text { based } \\
\text { livelihood } \\
\text { activity }\end{array}$ & $\begin{array}{l}\text { Group } 4 \\
\text { Rich } \\
\text { paddy } \\
\text { and local } \\
\text { livestock }\end{array}$ & $\begin{array}{c}\text { Group 5 } \\
\text { Small } \\
\text { farm } \\
\text { holder }\end{array}$ & $\begin{array}{l}\text { Group } 6 \\
\text { Paddy } \\
\text { scarce in } \\
\text { core zone }\end{array}$ & $\begin{array}{l}\text { Cluster } 7 \\
\text { Very rich } \\
\text { paddy }+ \\
\text { cardamom } \\
\text { in core } \\
\text { zone }\end{array}$ & Diff. \\
\hline $\mathrm{N}$ & 5 & 7 & 1 & 9 & 18 & 5 & 1 & \\
\hline $\begin{array}{l}\% \text { of hhs grow cardamom } \\
\% \text { of total whole sample }\end{array}$ & $\begin{array}{r}10.86 \\
8.33\end{array}$ & $\begin{array}{l}15.21 \\
11.66\end{array}$ & $\begin{array}{l}2.17 \\
1.66\end{array}$ & $\begin{array}{r}19.56 \\
15\end{array}$ & $\begin{array}{r}39.13 \\
30\end{array}$ & $\begin{array}{r}10.86 \\
8.33\end{array}$ & $\begin{array}{l}2.17 \\
1.66\end{array}$ & \\
\hline $\begin{array}{l}\text { Household } \\
\text { Age of household head } \\
\text { Year schooling } \\
\text { Household size } \\
\text { Number of labor }\end{array}$ & $\begin{array}{r}38 \\
5.60 \\
5.60 \\
2.6\end{array}$ & $\begin{array}{r}37.71 \\
1.86 \\
6.43 \\
3\end{array}$ & $\begin{array}{r}51 \\
0 \\
9 \\
5\end{array}$ & $\begin{array}{r}48.78 \\
1.22 \\
9.78 \\
5.56\end{array}$ & $\begin{array}{r}38.33 \\
2.06 \\
5.78 \\
3.17\end{array}$ & $\begin{array}{r}25.80 \\
8 \\
4 \\
2.20\end{array}$ & $\begin{array}{r}51 \\
0 \\
10 \\
6\end{array}$ & $\begin{array}{l}* \\
* \\
* \\
*\end{array}$ \\
\hline $\begin{array}{l}\text { Distance to closest agri- } \\
\text { cultural input shop }(\mathrm{km})\end{array}$ & 7.6 & 8.78 & 1.5 & 8.17 & 9.75 & 8.80 & 9 & n.s. \\
\hline $\begin{array}{l}\text { Distance to Sapa town } \\
(\mathrm{km})\end{array}$ & 16 & 14.5 & 9.5 & 17.28 & 19.80 & 33.80 & 34 & $*$ \\
\hline $\begin{array}{l}\text { Land } \\
\text { Rice area }(\mathrm{m} 2) \\
\text { Cardamom area }(\mathrm{m} 2) \\
\text { Per-capita cardamom area } \\
(\mathrm{m} 2) \\
\text { Total land use area }(\mathrm{m} 2)\end{array}$ & $\begin{array}{r}3596 \\
23200 \\
4321 \\
30578\end{array}$ & $\begin{array}{r}2604 \\
2678 \\
470 \\
6528\end{array}$ & $\begin{array}{r}3663 \\
4550 \\
505 \\
9433\end{array}$ & $\begin{array}{r}6947 \\
18716 \\
1989 . \\
27919\end{array}$ & $\begin{array}{r}3501 \\
13717 \\
2498 \\
19222\end{array}$ & $\begin{array}{r}1998 \\
12050 \\
3021 \\
15259\end{array}$ & $\begin{array}{r}13320 \\
200050 \\
20005 \\
222220\end{array}$ & $\begin{array}{l}* \\
* \\
* \\
*\end{array}$ \\
\hline $\begin{array}{l}\text { Livestock } \\
\text { Total big livestock } \\
\text { Total poultry } \\
\text { Hybrid pig } \\
\text { Local pig }\end{array}$ & $\begin{array}{r}9.4 \\
76.4 \\
6.6 \\
5.80\end{array}$ & $\begin{array}{r}0.43 \\
17.86 \\
0 \\
2.71\end{array}$ & $\begin{array}{r}0 \\
60 \\
0 \\
1\end{array}$ & $\begin{array}{r}5.22 \\
30.22 \\
0.78 \\
4.44\end{array}$ & $\begin{array}{r}3 \\
41.89 \\
0 \\
4.56\end{array}$ & $\begin{array}{r}0.4 \\
29 \\
0 \\
3\end{array}$ & $\begin{array}{r}4 \\
150 \\
0 \\
18\end{array}$ & $\begin{array}{l}* \\
* \\
* \\
*\end{array}$ \\
\hline $\begin{array}{l}\text { Income } \\
\text { Total net cash income } \\
(000 \mathrm{VND} / \mathrm{hh} / \text { year }) \\
\text { Per-capita net cash } \\
\text { income (000 VND/year) }\end{array}$ & $\begin{array}{r}101000 \\
18021\end{array}$ & $\begin{array}{r}15583 \\
\mathbf{2 7 6 0}\end{array}$ & $\begin{array}{r}107000 \\
11855\end{array}$ & $\begin{array}{r}50331 \\
\mathbf{5 3 1 0}\end{array}$ & $\begin{array}{r}34855 \\
\mathbf{5 9 3 4}\end{array}$ & $\begin{array}{r}30190 \\
\mathbf{7 5 3 0}\end{array}$ & $\begin{array}{r}455000 \\
45500\end{array}$ & $*$ \\
\hline $\begin{array}{l}\text { Income diversification } \\
\text { Simpson Diversity Index } \\
\text { Cardamom cash share } \\
\text { TimberNTFPs cash share } \\
\text { Tourism cash share }\end{array}$ & $\begin{array}{r}0.60 \\
44.29 \\
0 \\
3.91\end{array}$ & $\begin{array}{r}0.44 \\
\mathbf{3 9 . 0 1} \\
32.55 \\
1.25\end{array}$ & $\begin{array}{r}0.48 \\
9.27 \\
0 \\
67.4\end{array}$ & $\begin{array}{r}0.25 \\
\mathbf{8 4 . 8 8} \\
4.02 \\
0.23\end{array}$ & $\begin{array}{r}0.12 \\
92.31 \\
1.81 \\
0\end{array}$ & $\begin{array}{r}0.12 \\
\mathbf{9 2 . 4 5} \\
0.30 \\
0\end{array}$ & $\begin{array}{r}0.043 \\
\mathbf{9 7 . 8 0} \\
0 \\
0\end{array}$ & $\begin{array}{l}* \\
* \\
* \\
*\end{array}$ \\
\hline $\begin{array}{l}\text { Other characteristics } \\
\text { Livestock cash share }\end{array}$ & 34.61 & 0 & 0.74 & 1.64 & 1.98 & 0 & 2.19 & \\
\hline
\end{tabular}

ANOVA, at $5 \%$ of error probability 


\section{Group 1: Rich cardamom and livestock, diverse cash income source}

This group accounted for $10.86 \%$ of total cardamom cultivators and $8.33 \%$ of total households sampled. It is characterized by medium household size, medium education level of household head, large cardamom cultivated area ( 0.43 ha per capita in average), large number of livestock, high net cash income per capita earning from many different cash income sources. Simpson Diversity Index of 0.60 is the highest among groups. Household in this group pay attention on raising livestock toward market orientation presented by the livestock cash share of $34.61 \%$. Besides, these households start participate in tourism based livelihood activities. Although cardamom cultivation is the biggest cash income source, this group is probably not affected much when the government bans cardamom cultivation in HLNP. Members of this group are rich households locating in all four selected villages, belonging to all three ethnic groups. They stay scatter in both core zone and buffer zone with different distance to Sapa town.

\section{Group 2: Poor hh with land scarce, strong forest resource extraction}

The group represents $15.21 \%$ of cardamom cultivators and $11.66 \%$ of the whole samples. They are the poorest among groups illustrated by 15 million VND per year and landless represented by total land use area of 0.65 ha including cardamom cultivated area. Small animal such as local pig and poultry are raised for home consumption only. Their net cash income which is the lowest among groups is earned from forest farming (39.01\%) and forest resource extraction (32.55\%). Planting rice on small paddy area does not ensure rice security. Timber and NTFPs which become less and less in HLNP will not be their main cash income source in long term. Seven households in this group includes 6 poor Black H'mong households in three villages (Ta Van Giay 1, Seo My Ty and Sin Chai) and one non-poor Red Dan household in Ta Trung Ho village based on current poverty line of Vietnam. These poor households are highly vulnerable if cardamom cultivation in HLNP is banned.

\section{Group 4: Rich paddy and local livestock}

This group comprises $19.56 \%$ of cardamom cultivators and $15 \%$ of the whole sample. They are characterized by large household size, high labor force but low education level. They have the highest paddy area; however, rice consumption per capita is similar to several other groups due to large household size. They are highly dependent on cardamom represented by cardamom share in total net cash income of $84.88 \%$. Their livestock are the second largest among groups, never the less, raising livestock is primarily for home consumption. This group consists of Black H'mong and Red Dao households located in both core zone and buffer zone of HLNP.

\section{Group 5: Small farm holder}

This group is common. It accounts for $40 \%$ of cardamom cultivators and $30 \%$ of total households samples. These small farm holders are medium size households, low education level of household head. Their total land use area is about 2 ha. Cardamom is the most important cash income source with the share of $92.31 \%$. Livestock such as cattle, poultry and local pig are not only raised for home consumption but also for selling. These small farm holders are Black H'mong and Red Dao households located in both core zone and buffer zone of HLNP.

\section{Group 6: Paddy scarce in core zone}

This group accounts for $10.86 \%$ of cardamom cultivators and $8.33 \%$ of total households sampled. They are a group of small Red Dao households located in Ta Trung Ho village in the core zone of HLNP which is about $34 \mathrm{~km}$ far from Sapa town. Basic, their land use 
characteristics are quite similar to Group 5. They raise livestock for home consumption only. Dependence on cardamom cultivation and income diversification of this group is the same as Group 5, however, they have higher net cash income per capita. Moreover, household heads of this group has the highest education level and youngest age.

Two exceptional clusters (Cluster 3 and Cluster 7 in Table 9.6).

Cluster 3 represents a small number of households in study site which have very small agricultural area and small forest farm of cardamom. However, cardamom contributes only $9 \%$ in total net cash income. This small group has high income diversification demonstrated by the Simpson Diversity Index of 0.48 . Their high net cash income primarily comes from tourism-based livelihood activities with share of $67.4 \%$. In case cardamom cultivation is banned by the government, this group is not affected.

In case of our research, this household belongs to Black H'mong ethnic minority group and locates in Ta Van Giay 1 village in the buffer zone. The highest source of cash income is selling handicraft activities of the spouse. She was among the first Black H'mong group of selling handicraft products in Ta Van Giayl village when tourists started visit this village 20 years ago. Then, she moved to Sapa town to sell more products because almost tourists stay there. At present, she stays mostly in Sapa town and went home 2 times per week.

Cluster 7 comprises a small number of households located in the core zone. They have very large land area in which cardamom cultivated area under forest canopy reach 20 ha and other kinds of land use including terrace, sloping field, home garden reach about 2 ha. With large rice and maize productivity, they raise a lot of local pig and poultry for both home consumption and selling purpose. Besides, cattle such as buffalo and cow are raised for draught power. They have only two cash income generating activities in which cardamom contribute approximately $98 \%$ to the total net cash income. They have super net cash income of 450 million VND per year and super cash income per capita of 45 million VND per year compared to all other groups.

Despite one household belonging to this group in the whole samples, several key informant interviews stated that there are Black H'mong and Red Dao "Cardamom millionaire" located in core zone of HLNP. They could buy car easily whenever they want. Rich households of Red Dao ethnic group in Ta Trung Ho village stated that buying refrigerator, rice milling machine is easy but they do not have electricity from national lines to use those amenities. In our samples, two households which used to have car/truck are both located in core zone and have large land area as well as higher number of livestock.

\subsection{Economic loss when cardamom cultivation is banned in HLNP}

Figure 8.2 shows the cash income structure and Table 8.6 points out economic loss of different types of households in case the government bans all cardamom cultivation activities in HLNP. The group which do not involve in cardamom cultivation or involve in any wage labor relevant to cardamom cultivation will not be affected.

To simplify the household typology based on the dependence on cardamom cultivation, it is possible to arrange seven typological household groups into three categories:

- Highly depend on cardamom cultivation: Group 4, 5, 6 and 7

- Moderately depend on cardamom cultivation: Group 1 and 2

- Low dependence on cardamom cultivation: Group 3 


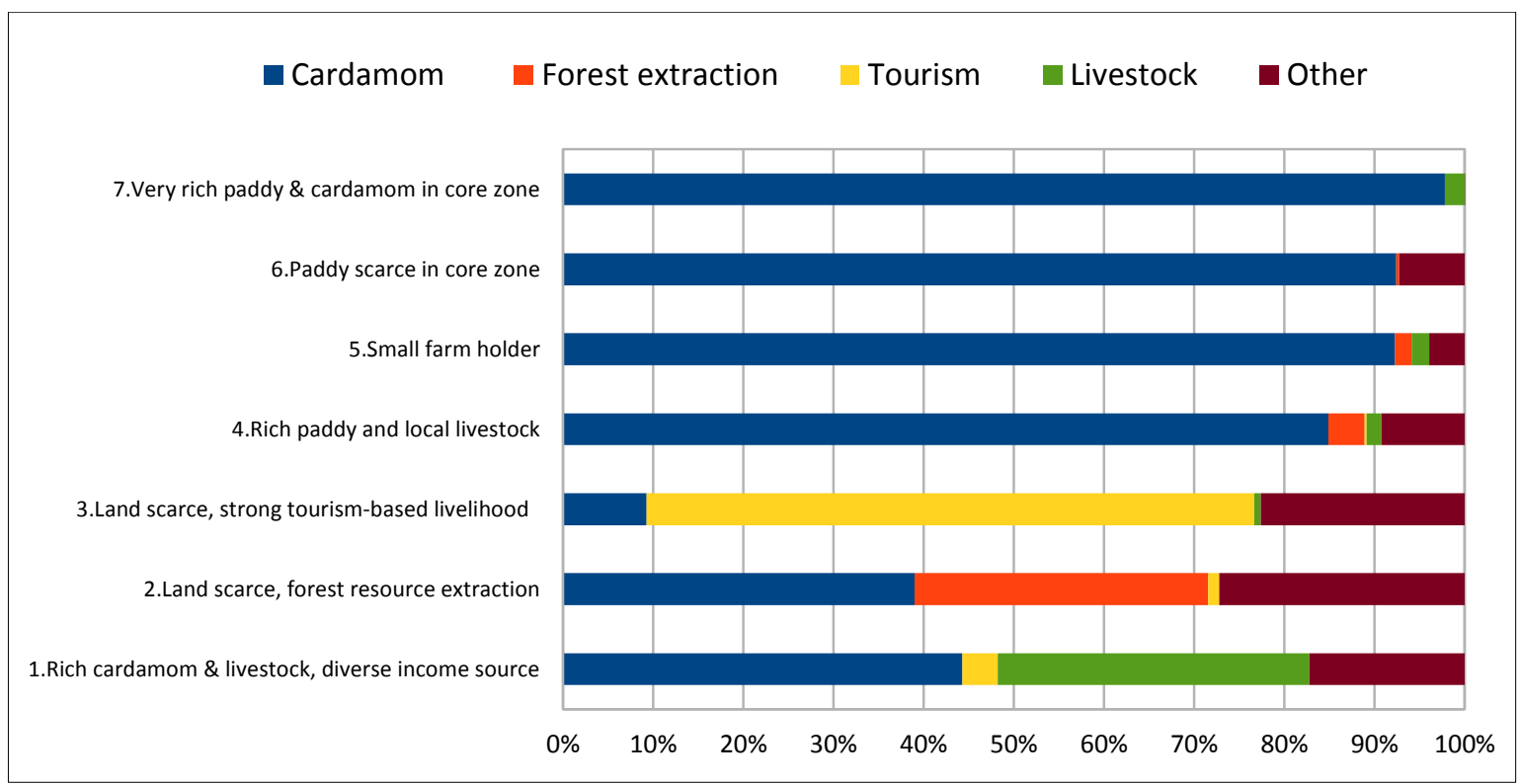

Figure 8.2 Cash income structure of typological households groups

The first group "Rich cardamom, livestock and diverse income source" will face the loss of 49 million VND which is the contribution of cardamom in total net cash income (Table 8.6). "Land scarce and forest resources extraction" typological households will face the loss of 6.41 million VND, meaning $39.01 \%$ of their current total net cash income. Among cardamom cultivators, households belong to type 3 will have smallest economic loss which equals to $9.27 \%$ of their current total net cash income, corresponding to approximately 10 million VND. Households belong to typology "rich cardamom and livestock, diverse income sources" will lose 49 million VND corresponding to $44.29 \%$ of total net cash income. However, they can sell more livestock to reduce economic loss.

With regard to households which have rich paddy and local livestock, $84.88 \%$ of their total net cash income, about 44 million VND will be loss if they stop cardamom cultivation. The economic loss is higher in highly cardamom dependent groups such as "Small farm holder" and "Paddy scarce in core zone" because cardamom shares about $92 \%$ of their total net cash income. In total, they will lose about 30 million VND. To the large typological household labeled "Very rich paddy and cardamom in core zone", almost all their net cash income will be loss with value of 445 million VND.

Table 8.6: Economic loss if cardamom cultivation is banned in HLNP by state power

\begin{tabular}{|l|c|c|c|c|c|c|c|c|}
\hline \multirow{2}{*}{ Economic loss } & \multicolumn{9}{|c|}{ Cardamom cultivation Category } & $\begin{array}{c}\text { Non } \\
\text { cardamom } \\
\text { cultivation } \\
\text { group }\end{array}$ \\
\cline { 2 - 9 } & $\begin{array}{c}\text { Group 1 } \\
\text { Rich } \\
\text { cardamom } \\
\text { and } \\
\text { livestock, } \\
\text { diverse } \\
\text { income } \\
\text { sources }\end{array}$ & $\begin{array}{c}\text { Group 2 } \\
\text { Poor hh } \\
\text { with land } \\
\text { scarce, } \\
\text { forest } \\
\text { resource } \\
\text { extractio } \\
\mathrm{n}\end{array}$ & $\begin{array}{c}\text { Cluster 3 } \\
\text { Land } \\
\text { scarce, } \\
\text { strong } \\
\text { tourism- } \\
\text { based } \\
\text { livelihood } \\
\text { activity }\end{array}$ & $\begin{array}{c}\text { Group 4 } \\
\text { Rich } \\
\text { paddy } \\
\text { and local } \\
\text { livestock }\end{array}$ & $\begin{array}{c}\text { Group 5 } \\
\text { Small } \\
\text { farmholder }\end{array}$ & $\begin{array}{c}\text { Group 6 } \\
\text { Paddy } \\
\text { scarce in } \\
\text { core zone }\end{array}$ & $\begin{array}{c}\text { Cluster } \\
\text { Very rich } \\
\text { paddy + } \\
\text { cardamom } \\
\text { in core } \\
\text { zone }\end{array}$ & \\
\hline $\begin{array}{l}\text { Portion of total net } \\
\text { cash income loss (\%) }\end{array}$ & 44.29 & 39.01 & 9.27 & 84.88 & 92.31 & 92.45 & 97.80 & 0 \\
\hline $\begin{array}{l}\text { Value(million VND/ } \\
\text { household)* }\end{array}$ & 49.35 & 6.41 & 9.90 & 44.19 & 31.16 & 28.75 & 445 & 0 \\
\hline
\end{tabular}

\footnotetext{
* Calculation based on the crop yield and selling price of cardamom in 2012.
} 


\section{Chapter 9}

\section{Potential livelihood activities of local people in the HLNP}

\subsection{Potentiality of current agricultural products in the HLNP}

\subsubsection{Annual crop}

It was clear that rice and maize production plays an important role in subsistence agriculture of local people in the HLNP. The production of 160 to $250 \mathrm{~kg}$ rice per capita per year (data from Annual report of Communal People Committee in Sapa district, Lao Cai province from 2011 to 2013) is lower than the average rice consumption of Vietnam which was $217 \mathrm{~kg}$ rice/year/capita (Ramziath T. Adjao and John M. Staatz., 2013). The production of maize is also low represented by the average amount per capita per year in range from $59.63 \mathrm{~kg}$ to $284.3 \mathrm{~kg}$ (data from Annual report of Communal People Committee in Sapa district, Lao Cai province from 2011 to 2013). Most respondents said that they grow a little maize for their children. Besides home consumption, local inhabitants of all ethnic group use rice and maize to feed their livestock such as pig and poultry. High elevation, geographical and climatic characteristics led to cultivation of one crop season per year with low crop yield. Rice and maize cultivated area per capita become less and less when household members separate from their family. Besides, a number of households produce not enough rice and need purchase more for home consumption. Although a few households in Ta Van Giay 1 village in the buffer zone sell traditional rice for other households and earn cash income, consumers had demand only when they celebrate New Year holiday and/or harvest festival (Lễ mừng cơm lúa mới) with small amount. Thus, it could be concluded that rice and maize production is not a potential activity of local people in the HLNP.

Table 9.1 SWOT analysis of annual crops in the HLNP

\begin{tabular}{|c|c|c|c|c|}
\hline Strengths & Weaknesses & Opportunities & Threats & Suitability \\
\hline \multicolumn{5}{|c|}{ Cereals (rice, maize) } \\
\hline $\begin{array}{l}\text {-High labor force } \\
\text {-Crop diversity }\end{array}$ & $\begin{array}{l}\text {-Limited land } \\
\text {-Soil quality } \\
\text {-Low crop yield } \\
\text {-Low profit } \\
\text {-Climate (one crop } \\
\text { season per year). }\end{array}$ & $\begin{array}{l}\text {-Use for humans } \\
\text { and livestock } \\
\text {-Traditional rice } \\
\text { has local market } \\
\text {-Crop residues } \\
\text { for livestock }\end{array}$ & $\begin{array}{l}\text {-Natural } \\
\text { resources } \\
\text { degradation }\end{array}$ & $\begin{array}{l}\text { Hhs with high rice and } \\
\text { maize producti-vity } \\
\text { such as Ta Trung Ho } \\
\text { villagers in the core } \\
\text { zone can sell cereal } \\
\text { for cash income } \\
\text { instead of } \\
\text { accumulation }\end{array}$ \\
\hline \multicolumn{5}{|c|}{ Vegetables } \\
\hline $\begin{array}{l}\text {-Trademark "Sapa } \\
\text { traditional vegetable" } \\
\text {-Avail paddy land in } \\
\text { off-rice season } \\
\text {-High labor force } \\
\text {-Domestic markets } \\
\text {-Seed available } \\
\text {-Avail manure }\end{array}$ & \begin{tabular}{|l|}
-Limited land \\
-Soil quality \\
-Limited species \\
(suitable to cool \\
weather) \\
-Low-skilled \\
farmer
\end{tabular} & $\begin{array}{l}\text {-Local market } \\
\text { available }\end{array}$ & $\begin{array}{l}\text {-Fog and } \\
\text { hoarfrost } \\
\text {-Import } \\
\text { vegetables } \\
\text { from China } \\
\text { illegally }\end{array}$ & $\begin{array}{l}\text { Households have large } \\
\text { land area, well- } \\
\text { educated farmer and } \\
\text { stay in the buffer zone } \\
\text { near Sapa town. Not } \\
\text { suitable for hhs living } \\
\text { in the core one of the } \\
\text { HLNP. }\end{array}$ \\
\hline
\end{tabular}


With regard to cassava production, most of local villagers in 4 villages surveyed do not grow cassava. However, cassava is planted in Ban Ho commune with the total area of 20 ha and productivity of 200 tons (data from Annual report of Communal People Commitee in Sapa district, Lao Cai province from 2011 to 2013). Through PRA conducted in La Ve village of Ban Ho commune where Tay ethnic minority group locate, it has been known that local people sell dry cassava. To have this product, farmers have to harvest cassava from the field and carry home, peel cover, cut fresh cassava into slices and dry them under sun energy several times at drying rate of 5 kilo fresh cassava equal $1 \mathrm{~kg}$ dried cassava. Difficulties including low price, high labor, transportation and far distance from Sapa town $(25 \mathrm{~km})$ prevents cassava become a potential crop product of the HLNP. Planting cassava for home consumption and raising livestock is dominant. Farm households sell it when the productive amount exceeds self-requirement.

Vegetables in the HLNP are mostly winter crops which are suitable to cool weather in the whole year of the region. Moreover, vegetables requires fertile soil, good water supply and drainage to grow and development whereas it is a limited condition in the HLNP. Farm households grow various kinds of vegetables in small home garden for self-sufficiency purpose; however, the amount is not enough. Local people with low education and literacy are not good in taking care of vegetables after planting. For example, H'Mong ethnic group rarely check the growth of crops and water as well as supply fertilizer, then, vegetables grow slowly. Poor households could not afford fertilizer even for main cereals. Local communities especially Black H'mong and Dao ethnic group stated that they often look for and collect wild vegetables in the forest for home consumption and livestock when they access forest. Giay and Tay households in Ta Van commune and Ban Ho commune expected that they would collect wild vegetables if available when they access forest for firewood collections. On the other hand, fog and hoarfrost always cause damage to vegetables and annual crops in Sapa district, Lao Cai province including a part of the HLNP. Over all, it could be concluded that vegetables is not a potential product of the HLNP. Other crops such as sweet potato, potato, taro, bean, canna... has low area and no potential to increase cultivated area due to limited land area. Fruit trees include peach, plum, lemon, banana and persimmon were planted scatter with several trees around house for subsistence. These products are also not potential for expand production in the HLNP.

\subsubsection{Livestock}

In term of livestock, the number of big livestock per household in three communes selected was low, such as buffalo in range from 0.74 to 1.28 , cow in range from 0.14 to 0.21 . Local people raise big livestock mostly for draught power on the fields. Cool weather and limited rainfall throughout the whole year lead to lack of pasture. Moreover, buffalo graze on the field cause crop damage. Therefore, local households always release big livestock in the forest, which leads to death of buffalo due to frozen in winter or falling in to cave or mountain hill during grazing. Although ethnic groups living in mountainous areas of Vietnam has been trained to keep buffalo/cow warm and provide food in winter, the mortality rate of big livestock is still high. Through the household survey, it has been know that a household in Ta Trung Ho village in the core zone of the HLNP also use big livestock as food in special event such as celebration of birthday for old household member, New Year holiday. Despite the fact that big livestock could be used as a cash income source in emergency case, $100 \%$ respondents chose the option of borrowing money from relatives, friends and neighbors first. In case they could not borrow money from any one, they will think of selling their assets including livestock. 
Raising big livestock could become a potential activity if local people grow grass to supply them enough food in dry season, not free rearing buffalo in forest especially in winter when food scarce and frozen negatively affect them. Another important step is separating big livestock from diseased one or from village if disease spread happens. It has been known that local people in Sin Chai village and Ta Trung Ho village started growing grass for livestock with the support of previous projects of the HLNP several years ago. Until now, each household has a small area of grass (Pennisetum purpureum) near their houses as a temporal food source for their buffalo. The household survey gave the result that households raising high number of big livestock $(10 \rightarrow 20$ heads/ household $)$ get annual income from selling livestock per year.

Table 9.2 SWOT analysis of livestock in the HLNP

\begin{tabular}{|c|c|c|c|c|}
\hline Strengths & Weaknesses & Opportunities & Threats & Suitability \\
\hline \multicolumn{5}{|c|}{ Small livestock (pig, poultry) } \\
\hline $\begin{array}{l}\text {-Trademark } \\
\text { "Local pig, local } \\
\text { poultry) } \\
\text {-Local used to } \\
\text { raise animals }\end{array}$ & $\begin{array}{l}\text {-Raising few } \\
\text { local livestock } \\
\text { for home use } \\
\text {-Low-skilled } \\
\text { farmer with } \\
\text { traditional } \\
\text { practices } \\
\text {-Lack of } \\
\text { experience and } \\
\text { financial capita to } \\
\text { invest in raising } \\
\text { hybrid livestock } \\
\text { for selling }\end{array}$ & $\begin{array}{l}\text {-Local market } \\
\text { (Vietnamese } \\
\text { tourists, } \\
\text { restaurants in } \\
\text { Sapa town) } \\
\text {-Supply is much } \\
\text { smaller than } \\
\text { demand }\end{array}$ & $\begin{array}{l}\text {-Disease spread } \\
\text {-Feedstuffs are } \\
\text { limited } \\
\text {-Feeds } \\
\text { competition } \\
\text { (home } \\
\text { consumption and } \\
\text { animal use) }\end{array}$ & $\begin{array}{l}\text {-Developing local } \\
\text { small livestock is } \\
\text { suitable for hhs } \\
\text { having abundant } \\
\text { cereals and big home } \\
\text { garden for livestock } \\
\text { food supply in both } \\
\text { core zone and buffer } \\
\text { zone } \\
\text {-Developing hybrid } \\
\text { small livestock is } \\
\text { suitable for hhs } \\
\text { located near agricul- } \\
\text { tural inputs to ensure } \\
\text { industrial food supply }\end{array}$ \\
\hline \multicolumn{5}{|c|}{ Big livestock (buffalo, cow, goat) } \\
\hline $\begin{array}{l}\text {-Draught power } \\
\text { and meet } \\
\text { consumption } \\
\text {-Source of cash } \\
\text { income in } \\
\text { emergency case } \\
\text {-High labor force }\end{array}$ & $\begin{array}{l}\text {-Traditional } \\
\text { practices (release } \\
\text { in forest) }\end{array}$ & & $\begin{array}{l}\text {-Extremely cold } \\
\text { weather in winter } \\
\text {-Disease spread } \\
\text {-Lack of food in } \\
\text { winter } \\
\text {-Damage to } \\
\text { forest }\end{array}$ & $\begin{array}{l}\text { Hhs grow grass to } \\
\text { maintain } \\
\text { livestock in food } \\
\text { shortage season. }\end{array}$ \\
\hline \multicolumn{5}{|c|}{ Fisheries } \\
\hline & $\begin{array}{l}\text {-Very limited } \\
\text { fishponds } \\
\text {-Very limited } \\
\text { species due to } \\
\text { cool weather } \\
\text {-Slow growth } \\
\text {-Low-skilled } \\
\text { farmer }\end{array}$ & -Local market & & \\
\hline
\end{tabular}


Raising pig and poultry primarily provides local households with food. H'Mong and Dao ethnic group in the core zone rarely sell these livestock but often use in traditional event such as wedding, funeral, New Year holiday, spray, harvest festival, building new wooden house... It has been observed that one household in Ta Trung Ho village in core zone of the HLNP use two pigs with total weight of $150 \mathrm{~kg}$ for party on the first date of building a new house. In contrast, Giay and Tay ethnic group in buffer zone raise small livestock for both self-sufficiency and market. However, high mortality rate of poultry due to spread disease which happens every year in many villages lead to the decrease in the number of poultry. For example, in Ta Van Giay 1 village where home-stay services develop, local villagers expected that food (meat) sent by hotels and travel agency with low quality (meat of dead pig and poultry, meat of diseased livestock) was probably one cause of spread disease in the village. Using water from stream helps spread disease from one household to other ones follow water flow. If mortality did not happen frequently, local people would have enough meat and other products for home consumption throughout the year. Due to frequent livestock disease, households raise limited number of stock and some even decided to stop raising livestock. In comparison to industrial livestock which use industrial processed food, local livestock of ethnic group in mountainous areas of Vietnam are famous to consumers in urban area due to its good meat quality and no chemicals involved in raising as well as processing process. Most restaurants in Sapa town in particular and in Vietnam urban areas in general put name of local pig and poultry on their sign boards to attract customers. In the HLNP, local pig and chicken could possibly potential products of the region. At present, black chicken in Ban Ho commune is well-known. Local people, especially ethnic group with low education and literacy need provision of knowledge on veterinarians to prevent epidemic diseases and breeding to reduce mortality rate.

"I raise about 60 chickens but when they were about $1 \mathrm{~kg}$, they died a lot due to disease. Other households have same situation. Our experience is that when we heard about mortality of chicken of another household, we tried to kill our chicken for eating" - Mr. C, supposed name, Sin Chai villager.

"Selling local pig and black chicken is easy. Many people from Sapa go to my village to buy, but we have only several pigs and chickens to sell. Local pig and chicken are free rearing, then, they grow slowly. It takes one year to raise a pig, therefore we do not want to sell. If we sell, then we must go to market to buy meat at higher price" - Mr. L, supposed name, villager of La Ve village, Ban Ho commune located in the buffer zone of the HLNP.

"I have stayed in Seo My Ty village for 6 years. Selling goods for local people does not help me earn much money, however, I raise 100 chickens behind my shops and bring to Sapa for selling to get cash income or sometimes killed and sell for local villagers here" Ms. Q, supposed name, a Kinh woman moved from Vinh Phuc province to Seo My Ty village in Lao Cai province for opening a small good shop in the village - "When disease spread, I must separate my chickens to avoid mortality. Some poor H'Mong households asked me to give them dead chicken for consumption. I always ask them to put fur in separated bag and wash meat carefully and put that washed water far away from the stream to prevent disease. Then, I saw that they put all fur and washed water near the stream. That's why then the whole village has disease spread"

\subsubsection{Aquaculture}

Fish ponds are very limited in villages selected for household survey. In the contrary, $70 \%$ of households in La Ve village, Ban Ho commune has fish pond with suitable variety such 
as grass carp and common carp, however, raising fish at household scale is not a potential market-oriented livelihood activity (Table 9.2).

\subsection{Potentiality of develop tourism-based livelihood activities in the HLNP}

Sapa town which is located in the buffer zone of the HLNP has become a famous location for tourism in Vietnam since 2000 due to its natural landscape, cool climate and diversity of ethnic groups. The number of visitors go to Sapa in period from 1992 to 2013 has significant increase from 5000 to more than 1 million (Table 9.3). It led to the formation of various tourism activities in the region such as opening hotels and restaurants, selling goods, guiding trekking tour, selling handicrafts products and home stay. In this section, home stay and selling handicraft will be considered strengths, weakness, opportunity and threats which helps identify whether this activity is potential or not as well as give recommendation for improvement. Other tourism-based activities such as mountain guiding, trekking guiding, sale of agricultural products are not considered because PRA and household surveys gave result that local in selected village do not participate in these activities. In fact, mountain guiding to Pansipan peak and trekking guiding gained financial benefits in term of employment opportunities because they must work for tourism agency and hotels in Sapa town and earn salary. Sometimes they get cash from tourists' tips. Experience of the researcher is that each tourist go to Pansipan peak must pay 55 USD, however, each guider/porter receives only 8 USD per working day even the tourists go in group of 40 people. Agricultural products in Sapa town are primarily provided by ethnic farmers in adjacent areas which do not belong to the boundary of the HLNP.

Table 9.3: Number of visitors come to Sapa district recently

\begin{tabular}{|c|c|c|c|c|c|c|c|}
\hline Year & 1992 & 2003 & 2005 & $2009 *$ & 2011 & 2012 & 2013 \\
\hline No. of visits & 5000 & 120000 & 200000 & 345000 & 510000 & 600000 & $>1000000$ \\
\hline
\end{tabular}

Source: Tran Huu Son, 2006 and Ha Thi Nga, 2013.

* Social economic report of Sapa district of period $2006-2007-2008-2009$.

\subsubsection{Home-stay}

Home stay services provided by Giay ethnic households in Ta Van Giay 1 village in Ta Van commune and Tay ethnic households in Ban Den village in Ban Ho commune not only increase diversity of cash income sources of operators but also contribute to improve infrastructure, encourage selling handicraft activities of H'mong and Red Dao ethnic group in the region which leads to improvement in local's living standard. This community-based tourism strategy should be developed in HLNP as well as in other protected areas of Vietnam. In order to find out strategic plan of developing this homestay services in these villages, it is necessary to identify the strengths, weakness, opportunities and threats (SWOT analysis) for this tourism-based livelihood activity.

Table 9.4 shows the SWOT analysis on homestay in Ta Van Giay 1 village in the buffer zone of the HLNP. Homestay in Ta Van has much strength including good location, crowded visitors and reasonable price. Visitors go to Ta Van because of its close location to Sapa town (distance of $8 \mathrm{~km}$ ), beautiful landscape formed of mountain, stream, Muong Hoa valley, traditional house of Giay and H'mong ethnic group and Sapa ancient stone areas. Tourists especially foreigners always go to Ta Van and enjoy home stay with old and tradition of Giay ethic group. Ta Van has started this service since 1998 and it had become a trademark name Homestay Ta Van. The price of staying overnight in Ta Van Giayl 
village is also reasonable which is $70000 \mathrm{VND}$ (about 3 USD per one person). Besides, local also cook for visitors and sell drinks to get more economic benefit. One beer helps local earn 1USD profit. The price of dinner-stay overnight-breakfast is 200000 VND (about 9 USD) per person. It is much lower compared to hotel, hostel and restaurants in Sapa town.

Table 9.4: SWOT analysis of homestay service in Ta Van Giay 1 village in the buffer zone

\begin{tabular}{|c|c|c|c|}
\hline Strengths & Weaknesses & Opportunities & Threats \\
\hline $\begin{array}{l}\text {-Ideal location } \\
\text {-High number of } \\
\text { tourists } \\
\text {-Reasonable price } \\
\text {-Trademark } \\
\text { "Homestay Ta } \\
\text { Van" }\end{array}$ & $\begin{array}{l}\text { - Absence of language } \\
\text { skill (English, French) } \\
\text { - Management } \\
\text { problem } \\
\text { - Weak co-operation } \\
\text { or competition among } \\
\text { local operators } \\
\text { (tragedy of commons) }\end{array}$ & $\begin{array}{l}\text { - Support from government } \\
\text { and NGOs for training } \\
\text { (language, cooking, } \\
\text { workshop on community } \\
\text { based tourism ,visiting } \\
\text { homestay operators at } \\
\text { home and abroad) } \\
\text { - Cooperation with travel } \\
\text { agency, hotel in Sapa town, } \\
\text { Hanoi and other provinces }\end{array}$ & $\begin{array}{l}\text { - Competition } \\
\text { with non-local } \\
\text { operators } \\
\text { - Unsafe food } \\
\text { prepared by travel } \\
\text { agency in Sapa } \\
\text { leads to disease } \\
\text { spread in village }\end{array}$ \\
\hline
\end{tabular}

Despite these strengths, homestay in Ta Van shows various weakness which should be eliminated. Operators could not speak basic foreign language such as English and French while most of tourists are foreigner. The community-based tourism Management board was established in 2008 which helped increase the price of homestay for all operators from 15 $000 \mathrm{VND} /$ person/ night to $25000 \mathrm{VND} /$ person/ night. Every night, operators has responsibility to go to one homestay in the village where Management board officers including village head, old village head and some villagers working as government officers meet and inform the number of guests and hand in $7000 \mathrm{VND} /$ guest/night. Moreover, sometimes the Management Board suddenly visits operators to check homestay quality, the number of guests and ask them to follow the rule. According to the increase market price, the homestay price in Ta Van Giay rose up steadily to $70000 \mathrm{VND}$ as the fixed price given by community-based tourism Management Board of Ta Van commune. However, operators tried to increase profit through increasing of number of tourists stay overnight. Therefore, despite the fixed price in the village, several operators went to travel agencies and hotels in Sapa town to order visitors with lower price such as 40 000VND and 50000 VND. It led to the sudden increase of number of visitors in these households and same actions in other homestay operators to maintain their number of visitors. This "tragedy of the common" clearly shows negative side later when travel agencies in Sapa town asked all operators to reduce the price. At present, the price ranges from $25000 \mathrm{VND}$ to $70000 \mathrm{VND}$ per one guest per night and it is over-control of the Community-based tourism Management board. Operators who inform the number of guests are some familiar households staying nearby the Management meeting location. Other households do not inform, even have bad manner when Management board sudden investigate. The activity of tradition performance stopped several years ago due to lack of incentive. It could be concluded that management problem along with weak co-operation among local operators have led to the broken of stability of homestay in Ta Van Giay 1 village.

Opportunities of homestay in Ta Van are supports from government and NGOs represented by different training periods such as cooking, basic communication in foreign language. At present, most operators can cook traditional Vietnam food, French fries, flour cake and making coffee, chocolate for tourist. Several operators had joined work shop on 
community-based tourism and visited other homestay in different provinces of Vietnam. Especially, one operator had chance to visit different hometays in France in one month and appeared in tourism website to connect to French tourist. The second opportunity is the connection of homestay operators to travel agency, hotel in Sapa town, Hanoi and different provinces which helps increase the number of guests besides walking tourists. Each operator has from one to several familiar companies which inform them the number of guest if available so that operator clean house, prepare food and sleeping facility in advance.

Ta Van homestay has several threats which should be minimized. The first threat is the competition between local operator and non-local operator. There are two bars in Ta Van Giay 1 villages and several restaurants which were opened by one Dutch person and Kinh people. These bars and restaurants with nice decoration supply food, drink with good music and provide homestay. It strongly compete with other local operators inside village especially households having drink signboard. Besides, several H'mong rent house of Giay ethnic households to do homestay with very attractive homestay price (25000 VND to 30 000 VND) and hire H'mong with strong English skill to welcome visitors from Sapa town. Moreover, they created bad story about local operators which are (1) Giay ethnic raise dogs which always barks tourists, (2) Giay ethnic prepare food which are not clean. Several key informant interviews mentioned that Dutch bar and H'mong often talk bad thing about local operator to foreign tourists which cause reduction in number of walk-by tourists stay in local house. The second threat mentioned by local operator is that food prepared by travel agency is possible cause of disease spread in their livestock. Normally, operators are responsible in buying food (meet, vegetable, rice, noodle) and cook for visitor in which they can serve visitors their agricultural output. However, to increase profit, travel agency and hotels in Sapa town often prepare these cooking materials. Meet sold in Sapa town are mostly industrial food from other areas because local raise livestock primarily for home consumption. Disease spread in livestock in Ta Van Giay village was possibly caused by disease source from industrial meet. In case of food prepared by travel agency, profit of homestay is non-significant. The agency pay operators only cooking fee which is very low whereas local use their rice, wine, tea and firewood, gas.

"Homestay brings the highest profit if tourists go in group of at least 4 people, stay overnight and enjoy both dinner and breakfast prepared and cooked by local and pay at least $50000 \mathrm{VND/person/night} \mathrm{for} \mathrm{sleeping.} \mathrm{It} \mathrm{would} \mathrm{be} \mathrm{great} \mathrm{if} \mathrm{they} \mathrm{drink} \mathrm{beer.} \mathrm{However,}$ if we have only two guests per day, and the company sends food, we have to cook our rice, ask them to enjoy our local wine and tea free and use our cooking energy. No tourism agency paid us these expenses. If they pay us exactly $70000 \mathrm{VND/one}$ night stay, we have $140000 \mathrm{VND}$ plus $30000 \mathrm{VND}$ cooking fee which equals to total expense. In case they paid only $25000 \mathrm{VND}$ to $30000 \mathrm{VND/one}$ night stay, we do not gain any profit, even loss. In case 2 guests pass by at noon and enjoy only lunch without drink beer, if the hotel send us food, we totally loss because the payment of $30000 \mathrm{VND}$ for cooking is not enough compared with rice, wine, tea, firewood/gas and our cooking time. When we complained, the company said that they will stop connection and work with other operators. Therefore, we must continue working with them and consider long term profit which is primarily gained from crowded tourists group or from selling beers and other kinds of drinks" - Key informant interview in Ta Van Giay village.

"Drinking tea is tradition of Vietnam. We serve visitors tea free. We cannot calculate money for tea because it will make tourists unhappy", Mr. L, supposed name - one respondent in Ta Van Giay village. 
"The company ask me to carry luggage for tourists. When tourists come, I must carry their luggage from the stop of car in another side of the stream to my house and vice versa when tourists leave whereas tourists go trekking. I must spend my petrol but no one pays me that expense. Despite reduce price of staying overnight, they also reduce payment such as if total money is 750 000VND, they will give us only 700000 VND. I love guests from tourism agencies in Hanoi the most because they do not send us food and they often pay us from 50000 VND to 70000 VND per one night stay", Mr. T, supposed name - one respondent in Ta Van Giay village.

Besides homestay in the buffer zone, some households located in the core zone of the HLNP also earn cash income from this livelihood activity. However, due to non-strategic location and lack of tourist visit, homestay in the core zone is not popular. Normally, the tourism agency ask one or two households which have large and clean house to welcome guests stay overnight and inform the local in advance the number of guests. The frequency of guests staying overnight in the core zone is very low represented by several groups per year. Tour guides must cook for guests and guests prepare their own sleeping bag. It was similar to homestay in Ta Van at its beginning in 1998 provided by one household. Cash income generated from homestay in the core zone is arranged as rare income.

Although homestay has several weakness and threats, it is still a potential livelihood activity in the buffer zone of the HLNP. Households doing homestay has additional job opportunity and cash income whereas their forest access frequency reduce. To improve homestay in the HLNP, it it necessary to strengthen the Community-based tourism Management Board in Ta Van commune as well as Ban Den commune to maintain and ensure the fixed homestay price. It is essential to remove homestay and bar opened by foreign people and H'mong as well as King people in the village using state power and improve relationship among local operators. It is essential to organize meeting for all households providing homestay service, make local operators understand the tragedy of commons and increase the cooperation between them. In another way, local government and local operators should take the best use of support from government and NGOs to study foreign language as well as improve cooking skills. The networking between local operators and travel agency in Hanoi, Lao Cai and other big cities should be developed.

\subsubsection{Handicraft}

H'mong and Red Dao have tradition of making their own colorful clothes and jewelry although it is time consuming and labor intensive. Historically, these ethnic groups sold their handicraft products for tourists who went to their villages despite limited communication between villagers and customers. The development of tourism in Sapa recently has led to the higher precipitation of ethnic group in producing and selling handicraft for tourists as souvenirs.

Handicraft sellers are often female elides and children who limited participated in working on farm and housework. People who have sold for a long time are willing to follow foreign visitors around and convince them to buy their goods without shy. Old handicraft sellers often stay in Sapa town and come back home 2 times a week. Younger sellers always follow tourists during trekking from Sapa town to other villages such as Lao Chai, Ta Van Giay, Cat Cat and convince until tourists buy their goods. They also come close and convince tourists who enjoy homestay in Giay or Tay ethnic households.

Due to time consuming in production, the goods sold by H'mong and Red Dao includes 
their own production, products which they buy from other people who cannot go to Sapa town for selling directly and Chinese products. Common goods are wallet, small bag for cell phone, embroidered clothing, handbag, hat, belt, hand string, jewelry and traditional musical instrument. One respondent started selling handicraft in 2013 revealed that she went to the Heaven Gate where tourists always visit at the weekend for selling handicrafts if it's not raining. She earns from 100000 VND to 400000 VND per week, equivalent to about 400000 VND to 1.5 million VND per month. Sapa town has many handicrafts sellers who has good English language skill and she feels embarrassed when they follow and convince tourists.

Among six selected village for conducting PRA, Cat Cat is famous for selling handicrafts and creating silver jewelry. However, most of handicraft shops on the stair taken to Cat Cat village belong to Kinh people who immigrated from other provinces and stay temporally in Sapa district for selling goods. It also happens in Sapa town. In Ta Van and Lao Chai commune in the buffer zone, many local H'mong and Red Dao ethnic woman stand on important sightseeing stops or walk follow foreign tourists in the popular trekking route Sapa-Lao Chai-Ta Van. In Ta Trung Ho village in the core zone of the HLNP where tourists rarely visit, several local girls prepare goods and follow the visitors from their village to Ban Den village which is about $10 \mathrm{~km}$. Besides cash income earn from selling goods, some can work as porters in case the tourists are too tired to carry their luggage. During long trekking to the core zone of the HLNP such as the route "Sapa-Lao Chai- Seo My Ty-Den Thang-Ta Trung Ho-Nam Toong-La Ve-Ban Den" with 35 km long, tourism agency always arrange homestay in several villages and inform the number of guests to homestay operators. Operators in the core zone are H'mong and Red Dao and they often talk to other neighbors so that local sellers and porters can arrange time and goods. Despite low frequency of tourists, some households in the core zone can earn additional cash income from these tourism activities.

In general, production and selling handicrafts are potential livelihood activities in the HLNP. It is necessary for local government to prevent the migration of Kinh people to Sapa for opening handicraft shops. The local will have more financial profit if they can sell their products directly to tourists. For long term activity, to develop tourism in Sapa, the problem of following and convincing foreign tourists until they buy one product should be decreased and stop permanently to create good impression to tourists. A high amount of handicrafts products in Sapa has source from China and other provinces. These products are imported to Sapa from Ha Khau immigration in Lao Cai province which is $50 \mathrm{~km}$ far from Sapa town through both legal and illegally import whereas local H'mong and Red Dao in Sapa district and other adjacent districts meet difficulties in selling their own products. If this problem is solved, local will gain more financial profit from handicraft.

With regard to the core zone in the HLNP, the project of community based tourism in Seo My Ty village has been figured out and accepted on paper at the end of 2013. Trekking tour from Sapa town to villages in the core zone become popular on many tourism website. It is likely that the number of tourists visit the core zone in the HLNP will increase in the near future which possibly leads to more participation of core-zone inhabitant in tourism based activities such as homestay, food and drink shops, selling handicrafts. Involved stakeholders such as Department of tourism, Community based tourism Management board should have strict prohibition on immigration of non-local to do business in these village from the beginning when the project is carried out in reality. Therefore, local could have more job opportunity and directly get profit from tourism activities, especially in Seo My Ty village where farmers lost agricultural land due to construction of Seo Trung Ho 
hydrological lake and dam. Training classes for local in core zone on operating homestay is important.

\subsection{Potentiality of other products in the region}

\subsubsection{Models introduced by HLNP and Sapa district in 2013}

In 2013, the HLNP management board and Sapa district People Committee introduced some agricultural models to local people in different villages in the national park (see Table 10.5 below). For each model, five trial households in selected village were supported material, technich and finance along with frequent investigation of involved government officers.

These models are introduced to selected households in Ta Van Giay 1 village and Seo My Ty village with purpose of finding alternative livelihood activities for cardamom cultivation. Although Black H'mong and Red Dao ethnic group are primary cardamom cultivators, most of models above were introduced in Ta Van Giay village because Giay ethnic has higher education as well as higher skill in agriculture production. Organizers expect that the success of these models will lead to the adoption of these new agricultural activities in all villages in the HLNP depending on livelihood capitals of each household.

Table 9.5 Models introduced by HLNP Management board and Local government in 2013

\begin{tabular}{|l|l|l|l|l|l|}
\hline Type & Model & Village & Support & Organizer & Note \\
\hline $\begin{array}{l}\text { Medical } \\
\text { plants }\end{array}$ & $\begin{array}{l}\text { Dảo cổ } \\
\text { lam }\end{array}$ & Ta Van Giay 1 & $\begin{array}{l}\text { Material, finance to } \\
\text { prepare soil in } \\
\text { garden }\end{array}$ & HLNP & $\begin{array}{l}\text { Local 's comment: } \\
\text { HLNP officers supply } \\
\text { variety off-season. It's too } \\
\text { cold for bud to grow and } \\
\text { develop. Almost buds die. }\end{array}$ \\
\cline { 2 - 6 } & Atiso & Ta Van Giay 1 & $\begin{array}{l}\text { Material, fertilizer, } \\
\text { investigation }\end{array}$ & $\begin{array}{l}\text { Sapa } \\
\text { district }\end{array}$ & $\begin{array}{l}\text { Easy to plant, good growth. } \\
\text { Evaluation of success will } \\
\text { be carried out in June 2014 }\end{array}$ \\
\hline Livestock & Dove & Ta Van Giay 1 & $\begin{array}{l}\text { Finance to build } \\
\text { fence, checking } \\
\text { fence quality, } \\
\text { supply variety (10 } \\
\text { doves/ household), }\end{array}$ & HLNP & $\begin{array}{l}\text { New trial, therefore, not } \\
\text { time of evaluation }\end{array}$ \\
\cline { 2 - 5 } & Goat & Seo My Ty & $\begin{array}{l}\text { 5000 000 VND } \\
\text { (equals to 2 goats) }\end{array}$ & HLNP & $\begin{array}{l}\text { Receive variety recently, } \\
\text { therefore, not time of } \\
\text { evaluation }\end{array}$ \\
\hline
\end{tabular}

Among these models, Dao Co Lam shows its failure because almost variety supported by the HLNP was dead due to off crop season. There is limited information of Dao Co Lam cultivation in Vietnam in general and in Sapa district in particular, therefore, the researcher cannot calculate the economic efficiency of this kind of plant to compare with cardamom cultivation. Other models was not evaluated, therefore the researcher identify the potentiality of each model based on SWOT analysis. 


\subsubsection{Potentiality of growing Atiso in cultivated land in the HLNP}

Atiso (Cynara Scolynus Lour) is one kind of cash crops in Sapa district, Lao Cai province; however, it is planted in adjacent areas of the HLNP such as Ta Phin, Hau Thao and in Sapa town with total area of 32 ha.

Atiso has much strength to develop in HLNP. It Climatic condition in the HLNP is suitable for Atiso's growth and development. The crop season of Atiso started from July, August to the June in the following year, therefore, the local could use paddy land after harvesting rice to plant Atiso. After harvesting Atiso, the local can grow either paddy rice or Atiso again. All parts of Atiso can be harvested and sold such as leaves (5 to 6 times of harvest with the first time at 90 days after seeding and the next is 45 days after), flower, fruit, seed, stem and root. Besides, cultivators possibly use Atiso flower for home consumption as vegetable. Atiso brings cultivator high profit which is estimated as 4 times higher than rice production (Key informant interview in Ta Van Giay 1 village).

Table 9.6. SWOT analysis of Atiso (Cynara Scolynus Lour) in Sapa district

\begin{tabular}{|c|c|c|c|}
\hline Strengths & Weaknesses & Opportunities & Threats \\
\hline $\begin{array}{l}\text {-Suitable climatic condition } \\
\text {-New grower can learn } \\
\text { experience from adjacent areas } \\
\text {-Avail paddy land in off rice } \\
\text { season } \\
\text {-High labor force } \\
\text {-Aval all parts of Atiso plants } \\
\text { (use as medical and vegetable) } \\
\text {-High profit }\end{array}$ & $\begin{array}{l}\text {-High price of variety } \\
\text {-Require investment } \\
\text { in irrigation system to } \\
\text { maintain moisture }\end{array}$ & $\begin{array}{lr}\text {-Traphaco } & \text { medical } \\
\text { company } & \text { buy } \\
\text { Actiso } & \text { leaves }) \\
\text { with stable price }\end{array}$ & $\begin{array}{l}\text {-Dry and sunny } \\
\text { negatively } \\
\text { affect growth }\end{array}$ \\
\hline
\end{tabular}

Despite various strengths listed above, Atiso has several weaknesses including high price of variety and require moisture throughout its crop season. Each $\mathrm{kg}$ of Atiso seed cost 5 million VND (approximately 250 USD). Dry and lack of rainfall will negatively affect the growth of this plant, even cause death. Local should invest in constructing irrigation system including a water tank and sprinkler irrigation system to water Atiso on sunny days. It increases production cost of Atiso although good sprinkler irrigation system can be used for 5 to 6 years.

Growing Atiso in paddy land in the HLNP has high opportunity of market. The Traphaco medical company located in Sapa town has bought Atiso leaves for producing medical products with the price of $2500 \mathrm{VND} / \mathrm{kg}$ in 5 years. Besides Atiso leaves, local can sell other plant part in local market. At present, Sapa district has plan to expand Actiso area in Ta Van, Lao Chai, Hay Thai, Ta Shin and Sapa town to 51 ha in 2014 in which cultivators are provided with variety.

With this SWOT analysis, it is possible for households in the HLNP use paddy land to grow Atiso. Households which produce abundant rice can use paddy area to plant activist all year around to generate cash income. Households with limited paddy rice can take the best use of paddy land after harvesting rice to grow this kind of medical plant. Support of local government and Traphaco medical company in the regions helps local reduce production cost whereas ensuring production output. 


\subsubsection{Potentiality of raising dove in the HLNP}

Among 60 households sampled in four villages, dove is raised in Sin Chai village by a H'mong household. Besides, dove is also raised in Ta Van Giay 1 village. In comparison to other animals, dove has various strengths which are low cost, small area, food availability, easy and high profit (Table 10.7). To start raising dove, local need to spend several million VND on making fence, buying variety which is 5 to 10 dove couples and use rice combined with cassava and bean as food. Each couple possibly reproduces eggs and hatch to 10 doves per year. The period from dove variety to reproductive dove is about 3 months. Suppose that after six months, each household has 35 dove couples in reproduction age. Every month, household have 15 couple of dove variety per month with the selling price of $250000 \mathrm{VND} /$ couple, meaning that the gross income will be 3.75 million VND. The food cost of 35 dove couples in reproduction age in one month is about 1 million VND per month plus the food cost for 15 dove babies until selling. Based on this calculation, the net cash income of raising dove is about 2.5 million VND per month which is considered as high income of farmers whereas this activity does not require much labor. Besides selling dove variety, local also can sell dove for meat at Sapa town where there is a high number of restaurants for tourists.

Table 9.7 SWOT analysis of raising dove

\begin{tabular}{|l|l|l|l|}
\hline Strengths & Weaknesses & Opportunities & Threats \\
\hline -Low cost & -Lack of experience & -Local market & -Disease may spread \\
-Does not require large area & & & \\
- -Easy & & & \\
-High profit & & & \\
\hline
\end{tabular}

The weakness of raising dove in HLNP is the lack of experience of local. A few of households raise dove in the region. If this model is applied in villages in the HLNP, it is necessary to have training class and/or guidance combined with frequent investigation of extension service and local agricultural officers. Households which have abundant rice and maize are suitable for raising dove. Other households which must purchase rice for home consumption can start this activity with two dove couples at the beginning and increase production steadily when doves reproduce. The difficulty in raising dove is that poultry in villages in HLNP often has disease spread and it may negatively affect dove.

\subsubsection{Potentiality of raising goat in the HLNP}

As mentioned in the first section of this chapter, big livestock has potentiality to develop in Seo My Ty village where most agricultural land loss due to construction of hydrological lake and in Ta Trung Ho village where Red Dao ethnic group grow grass for feeding livestock in food shortage season. The model of raising goat in Seo My Ty village introduced by the HLNP in 2013 has various strengths and opportunities. Goat are easy to raise. They are released along road and field after harvesting rice in the morning to graze and taken to fence in the late afternoon. Goats have high production. Four goats (two couples) possibly develop to 30 goats in four years. It is easy to sell goat in Sapa because a few household raise goats. Buyers from Sapa town go to villages in the core zone such as Seo My Ty, Den Thang and Ta Trung Ho for buying goat. The problem of raising goat in the HLNP is the low skill of ethnic group. Local always release goat for free grazing and do not keep goat in livestock fences. It negatively affects rice, maize in the fields and 
vegetables in home garden during crop season. Besides, goats eat small plants and negatively influence biodiversity in the HLNP.

Table 9.8 SWOT analysis for raising goat in Seo My Ty village of the HLNP

\begin{tabular}{|l|l|l|l|}
\hline Strengths & Weaknesses & Opportunities & Threats \\
\hline $\begin{array}{l}\text {-Easy } \\
\text {-High reproduction } \\
\text {-Good profit }\end{array}$ & $\begin{array}{l}\text {-Low skilled farmer } \\
\text {-Require care in } \\
\text { cop season }\end{array}$ & -Local market & $\begin{array}{l}\text {-Negative affect biodiversity if } \\
\text { local release free-grazing } \\
\text {-Negative affect rice and maize } \\
\text { in crop season }\end{array}$ \\
\hline
\end{tabular}

It is difficult to identify that raising goat is a potential livelihood activity which replace cardamom cultivation in HLNP if local farmers keep traditional method of free grazing. In case of raising goat in garden with fence around and local cut natural plant combined with planting grass for supplying food, raising goat will have high potentiality.

\subsection{Summary of potential income-generating activities in the HLNP \& adjacent areas}

Although one objective of this study is identifying potential alternative livelihood activities, cardamom has very high contribution to total cash income of almost cardamom-cultivator groups. It is difficult to find alternative livelihood activities. Instead, the researcher identified potential livelihood activities in the region which generate cash income. Improving current livelihood activities combined with introduction of these livelihood activities helps local people generate more cash income, based on that, increase diversity of income sources and reduce dependence on cardamom.

Based on SWOT analysis in previous section, characteristics of selected villages which was given in the study profile and characteristic of each typological households group (on page 75 and 76), it is possible to summarize potential cash-income generating activities besides cardamom cultivation for each selected village in the HLNP as well as the typological household should adopt (Table 9.9).

- Planting vegetables are suitable for Group 4 (Rich paddy and local livestock) in La Ve and Ta Van Giay villages in the buffer zone. They locate near the main road to Sapa town and high crop yields. It is suitable for planting safe vegetables on paddy field after harvesting rice for selling inside village and Sapa town where tourism develops. Giay and Tay ethnic group also have better agricultural practices than two others ethnic groups.

- Atiso cultivation are suitable for households which possess large area of paddy such as group 4 (Rich paddy and local livestock) in La Ve and Ta Van Giay village and group 7 (Very rich paddy and cardamom in the core zone) in Ta Trung Ho village. These households use a part of their paddy for planting Atiso and can change from Atiso to rice in any year because transplanting rice season starts after harvesting Atiso. To households in Ta Trung Ho village, it's easy to invest in Atiso plantation, however, the road from Ta Trung Ho village to Ban Ho commune should be improved for facility both agricultural input and output transportation.

- Raising big livestock are suitable for households in Sin Chai village in the buffer zone and two selected villages in the core zone. Group 1 (Rich cardamom and livestock, diverse income sources) and Group 4 (Rich paddy and local livestock) have experiences in raising big livestock. Developing livestock by reducing free grazing in forest, increasing time in 
pen and grow grass for feeding helps reduce mortality in winter due to severe cold, food shortage and falling accident in the mountain.

Table 9.9. Summary of potential livelihood activities in the HLNP

\begin{tabular}{|c|c|c|c|c|c|c|c|c|}
\hline \multirow{3}{*}{$\begin{array}{l}\text { Livelihood } \\
\text { strategy }\end{array}$} & \multirow{3}{*}{$\begin{array}{l}\text { Potential } \\
\text { livelihood } \\
\text { activities }\end{array}$} & \multicolumn{6}{|l|}{ Village } & \multirow{3}{*}{$\begin{array}{l}\text { Group of } \\
\text { cardamom } \\
\text { cultivator } \\
\text { may adopt }\end{array}$} \\
\hline & & \multicolumn{4}{|c|}{ Buffer zone } & \multicolumn{2}{|c|}{ Core zone } & \\
\hline & & Cat Cat & Sin Chai & $\mathrm{La} \mathrm{Ve}$ & $\begin{array}{l}\text { Ta Van } \\
\text { Giay } 1\end{array}$ & $\begin{array}{l}\text { Seo My } \\
\text { Ty }\end{array}$ & $\begin{array}{l}\text { Ta Trung } \\
\text { Ho }\end{array}$ & \\
\hline \multirow[t]{2}{*}{$\begin{array}{l}\text { Crop } \\
\text { cultivation }\end{array}$} & $\begin{array}{l}\text { Safe } \\
\text { vegetable }\end{array}$ & & & $\mathrm{x}$ & $\mathrm{x}$ & & & 4 \\
\hline & Atiso & & & $\mathrm{x}$ & $\mathrm{x}$ & & $\mathrm{x}$ & 4,7 \\
\hline \multirow[t]{4}{*}{ Livestock } & $\begin{array}{l}\text { Big } \\
\text { livestock }\end{array}$ & & $\mathrm{x}$ & & & $\mathrm{x}$ & $\mathrm{x}$ & 1,4 \\
\hline & $\begin{array}{l}\text { Local pig, } \\
\text { poultry }\end{array}$ & $\mathrm{x}$ & & $\mathrm{x}$ & $\mathrm{x}$ & & $\mathrm{x}$ & 1,4 \\
\hline & $\begin{array}{l}\text { Hybrid pig } \\
\text { and poultry }\end{array}$ & & & $\mathrm{x}$ & $\mathrm{x}$ & & & 1,4 \\
\hline & $\begin{array}{l}\text { Raising } \\
\text { Dove }\end{array}$ & $\mathrm{x}$ & $\mathrm{x}$ & $\mathrm{x}$ & $\mathrm{x}$ & & & $2,5,6$ \\
\hline \multirow[t]{2}{*}{ Tourism } & Homestay & & & $\mathrm{x}^{*}$ & $\mathrm{x}^{*}$ & $* *$ & $* *$ & 6,7 \\
\hline & $\begin{array}{l}\text { Handicrafts } \\
\text { production } \\
\text { and selling }\end{array}$ & $\mathrm{x}$ & $\mathrm{x}$ & & $\mathrm{x}$ & $* *$ & $* *$ & 3,6 \\
\hline \multicolumn{9}{|c|}{$\begin{array}{l}* \text { Homestay operators are Giay and Tay ethnic group w } \\
* * \text { has potential to start and develop in the near future }\end{array}$} \\
\hline \multicolumn{5}{|c|}{$\begin{array}{l}\text { Group 1: Rich cardamom and livestock, diverse income } \\
\text { sources } \\
\text { Group 2:Poor with land scarce, cardamom scare, strong } \\
\text { forest resource extraction } \\
\text { Group 3: Land scarce, low cardamom, strong-tourism based } \\
\text { livelihood activity }\end{array}$} & \multicolumn{4}{|c|}{$\begin{array}{l}\text { Group 4: Rich paddy, rich cardamom and local } \\
\text { livestock } \\
\text { Group 5: Small farmholder, medium cardamom } \\
\text { Group 6: Paddy scarce in core zone, medium } \\
\text { cardamom } \\
\text { Group 7: Very rich paddy and cardamom in core } \\
\text { zone }\end{array}$} \\
\hline
\end{tabular}

- Raising pig and poultry are suitable for households which produce enough rice and maize for home consumption. In another word, it is suitable for Group 1 and 4. Seo My Ty village and Sin Chai village has high percentage of hunger, therefore, it's not suitable to develop raising local livestock for market there. In case of raising hybrid small livestock, households must spend more money in buying industrial food for their livestock and has knowledge in pen protection and disease prevention. Therefore, raising hybrid livestock is more suitable to Giay and Tay ethnic groups in La Ve village and Ta Van Giay 1 village more than Red Dao and H'mong ethnic groups in other villages remaining.

- Raising dove can be introduced to all groups, however, it is dangerous if all groups raise dove for market. It is better if dove is introduced to poorer groups such as Group 2, 5, 6 because it does not need high input investment. It is also suitable for the buffer zone more than core zone thanks to advantages in market.

- With regard to tourism based livelihood activities, households belong to Group 3,6,7 may adopt. Homestay and selling handicraft has potential to develop in the core zone in the near 
future when tourism projects are carried out in the core zone.

At present, cardamom as the most important source of cash income thanks for its profit. Local people consider cardamom as their only potential cash income source. Prohibiting cardamom cultivation in the HLNP will seriously affect most of household groups. It is impossible to ban cardamom cultivation in the HLNP immediately although cardamom covered almost evergreen forest areas in the HLNP at present. What HLNP Management Board has done was prevention of expanding cardamom area in recent years through information channels (Key informant interview). It will take several years to evaluate the success of each development model. When local see that other livelihood activities bring higher profit than cardamom, they will change from cardamom to these activities.

The household survey gave results that when cardamom cultivation in the HLNP is banned by the government, $30 \%$ of cardamom cultivators would follow the arrangement of the government, meaning that they will grow plants and/or raise type of animals given by the government. It is similar to the banning of opium in 1986 and growing of cardamom instead. All respondents stated that they were not supported anything by the government when they grow cardamom. However, elders in the village had cultivated cardamom before the establishment of the HLNP and it was not banned by the state power.

Table 9.10 Choosing of respondents about alternative livelihood activities in case cardamom cultivation is banned in the HLNP

\begin{tabular}{|l|c|c|}
\hline Option & $\mathrm{N}$ & $\%$ \\
\hline $\begin{array}{l}\text { Follow arrange of the government } \\
\text { (plant tree or raise animal which government supports) }\end{array}$ & 14 & 30.4 \\
\hline Do not know & 14 & 30.4 \\
\hline Selling wage labor & 3 & 6.5 \\
\hline Raising goat & 2 & 4.3 \\
\hline Cardamom will not be banned & 13 & 28.2 \\
\hline Total & 46 & 100 \\
\hline
\end{tabular}

$30 \%$ of cardamom cultivators do not know what they do instead of cardamom cultivation. $6.5 \%$ of cardamom cultivators revealed that they will do off farm or non-farm activities as wage labor to get cash income. Another 5\% of cardamom growers decided to raise goat for generating cash income. $30 \%$ of cardamom cultivators left mentioned that the government will not ban cardamom in any circumstance because cardamom helps protect the forest (Table 9.10). Reducing cardamom cultivation in the HLNP will be time consuming because it takes long time for local people to see which alternative livelihood activities are potential and easy to adopt in their condition.

With regard to experience in the past, cardamom cultivator group stated that they were not supported anything either by the government or other offices when they start cardamom cultivation instead of opium cultivation. However, the fact that (1) cardamom is available in period of planting opium and (2) elders in the village had cultivated cardamom before the establishment of the HLNP were advantages of local at that time. 


\subsection{Income diversification or replacement of cardamom cultivation by other livelihood activities?}

Cardamom cultivation is harmful to biological resources in the HLNP due to the clearance of forest ground cover and other negative influences during processing process in the forest. However, replacing cardamom by any other kind of crop is not a suitable solution. Cardamom had been encouraged to plant in the region because it can grow under forest canopy and local people did not cut down forest and do slash and burn. Different from other crops such as maize, rice, cassava and bean..., cardamom cause negative effect in long term. Tree which provides shade for cardamom will die in next 30 to 50 years and it may lead to the disappear of the protected area.

"At present, cardamom is everywhere in the national park, even near Pansipan peak. First, local grow it in natural forest, then, they grow in generation forest, and now they climb to the hill to plant this spice. Cardamom is throughout the national park, even in Gold stream area which is a scenic spot in the region. In next 30 or 40 years, the whole forest will disappear if there is no way to remove cardamom", Mr. C, Officer of the HLNP

"Banning cardamom cultivation immediately is impossible...Local grow cardamom because they do not see any other crop or any other thing to do to have high profit like cardamom", Mr. M, Officer of the HLNP.

It's important to diversify income of local people to reduce the dependence of local people on cardamom. This objective is obtained through improving other livelihood activities and introducing new potential livelihood activities, especially cash-income generating activities. The replacement of cardamom by another kind of crop has to be rejected due to negative effects in both short term and long term. In another way, it requires to prevent a second commercial crop in the protected area. That is the reason why potential livelihood activities in the core zone are related to livestock more than crops and local are encouraged to grow grass as well as taking the best use of crop residues for feeding livestock.

Complete replacement of cardamom is impossible and it takes a long time to do whereas livelihood of local people must be satisfied. Thus, improving current livelihood activities or introduction of new livelihood activities, it requires to grow new trees on cardamom field for replacing current available trees in the future through models, for example:

Suppose that $80 \%$ of land of one field is now covered by cardamom and $20 \%$ of land is tree for shade. The local participating in the model will reduce the cardamom area to $70 \%$ and let small tree grow, not remove them during weeding. Similarity, other models could be set up, such as $60 \%$ of land is covered by cardamom and $40 \%$ is covered by tree for shade.

To age-old cardamom fields which are not productive, local people could apply the model of forest plantation in which cardamom is removed and native timbers such as pine, Talauma gioi and other trees follow the plan of the HLNP and Forest Department. It is similar to participation of local people in 661 program of the government in 2003 in the region in which local are paid for planting and taking care of trees whereas they also get benefit from growing crops around these timbers in several first years when canopy is limited. 
In processing cardamom, local people extract a large amount of firewood in the HLNP. During the survey, the researcher saw the difference between the drying oven of Red Dao ethnic group and of Black H'mong ethnic group. Drying oven of Red Dao ethnic group is smaller, lower and less energy requirement because they dig soil and put a frame on soil to contain cardamom. Firewood is put under the frame for drying. The drying oven is closed and heat is kept inside the oven. It does not require labor to take care of the drying oven during processing. Local go to other fields to harvest cardamom and come back later for putting more firewood in the oven. In contrast, Black H'mong makes a small wooden house in the field and dry cardamom there. Drying cardamom is like cooking in the kitchen. The frame for containing cardamom is high and it requires more firewood due to energy loss in every directions. Moreover, it requires having a labor to check firewood, cardamom sometimes during processing. Several Red Dao respondents complained about high firewood consumption in processing cardamom of Black H'mong ethnic group. To reduce firewood extraction in cardamom production, opening training class for Black H'mong ethnic group in building cardamom drying oven is requires.

In general, the success in reduce cardamom cultivation in the HLNP is related with the success in improvement current livelihood activities of local people, introduction and adoption of new livelihood activities. Improving agricultural practices to ensure food security is essential to decrease reliance of local people on limited biological resources in the protected area. Processing cardamom also needs improvement for saving fuel energy. 


\section{Chapter 10}

\section{Discussion, Conclusion and recommendations}

\subsection{Discussion}

\subsubsection{Characteristics of respondents and households sampled}

The study found that inhabitants in the HLNP belong to Black H'mong, Red Dao, Giay and Tay ethnic groups in which Black H'mong is the dominant ethnic group. The female population is smaller than the male population, especially in the core zone of the HLNP. This is possibly explained by the poor living conditions and limited access to health service (UNFTA, 2011). Ethnic minority groups in Vietnam primarily live in mountainous areas which is isolated and inaccessible (Amin and Teerawichitchainan, 2009). H'mong and Red Dao ethnic group has tradition of living in high elevation area, that's why they live in the core zone of the HLNP where there was no health service station, which caused high mortality rates in females. When they have diseases such as sore eyes, temperature or bitten by the snake and the female gives birth, the local in the core zone use medical plants to treat themselves and/or invite local vaidhya along with worship. Moreover, the road from the core zone to the buffer zone is difficult for transportation, especially in raining season which possibly affected the frequency of going to health care stations located in buffer zone.

The study gave results that average household size is 6.1. It is much higher than average household size of entire country (6.1 versus 3.8, respectively) (UNFTA, 2011). The household size is higher in the core zone where Black H'mong and Red Dao ethnic group live. The reason is that ethnic groups such as Giay and Tay living in the buffer zone has lower fertility rate than H'mong and Red Dao (UNFTA, 2011).

High illiterate and low education of local people living in both zones of HLNP could be explained by low education access, long distance to get to school, high drop-out rate and lack of ethnic minority teachers (World Bank, 2009). At present, most of children in the HLNP go to school thanks to free tuition fee in villages located in the core zone as well as poor villages located in the buffer zone. It is necessary to have bilingual teachers at nursery and primary school to increase the understanding and reduce the drop-out rate of pupils. Most of respondents have stayed in villages since they were born. With low education and less mobility, ethnic minority groups in the HLNP have difficulties in approaching ideas, technology, new intervention in agricultural production as well as other industries (World Bank, 2009). That is possibly one reason for the high dependence of local people on forest resource in the HLNP and traditional agricultural production with age-old practice. The study showed that $95 \%$ local community grows rice, $92 \%$ grow maize and around $85 \%$ grow vegetables. It is consistent with results given by Vietnam Living Standard Surveys in 1993 and 1998 and Vietnam Household Living Standard Survey in 2002 that among rural in Northern Uplands of Vietnam around 90\% plants rice, $85 \%$ grows other food and about $85 \%$ grows vegetables (cited in Minot et al, 2006). A few people has job which requires good knowledge and skills such as government officer, construction worker and carpenter. Off-farm jobs and non-farm jobs are only available in a short time. For example, agricultural wage labor in cardamom season (September to December), making and/or fixing wooden house at the end of one year, construction worker during road construction period and increase tourism-based activities in high season. 
Study area of previous research about cardamom in Vietnam (Turner, 2007; Tugalt-Lafleur and Turner, 2009; SNV, 2009) was cardamom regions in the North in general and Sapa district in particular which is one administrative unit of Lao Cai province (SNV (2009). Moreover, they mostly focused on techniques in planting this spice and its value chain. Different from those researches, our study focused on cardamom in the boundary of the protected area and considered cardamom as one forest-based livelihood activities called forest farming. The study shows no statistical significant difference in households' land holding between two zones of the HLNP, however, total land use area in the core zone is statistically significant higher than that one in the buffer zone. Establishment of the national park to conserve biodiversity is "the chief strategy" (Perspha et al, 2010: 2918) but it leads to the prohibition of going to forest and extracting forest resources. In the HLNP, local people are prohibited to clear forest, slash and burn, extract timber and NTFPs and hunting animals. Thus, a large proportion of land holding of local consists of terraces and swidden areas before the establishment of the HLNP. Land holding of households in the HLNP will reduce steadily due to population increase, separation of small family from a big household along with land division. On the contrary with limited expansion of swidden areas, cardamom area was continuously expanded in the HLNP by local due to its high profit and encouragement of government to replace opium until recent time when involved stakeholders see its negative effects on biodiversity conservation and made effort to stop its expansion. Therefore, core zone inhabitants have larger cardamom area and larger total land use than buffer zone residents.

Housing condition of Red Dao ethnic group in Ta Trung Ho village in the core zone is the best among households sampled. Their wooden houses has window with glass, cement floor or marble floor, color wall, decoration inside the house and toilets adjacent to the house. Households operating home-stay is Ta Van Giay village have second best housing quality with nice look, bathroom and toilet. Most of other households are wooden house with soil floor, no bathroom and no toilet. Poor H'mong ethnic households in Sin Chai village are often very small. Lack of bathroom and toilet happens in all selected villages and popular in villages of Black H'mong such as Sin Chai in the buffer zone and Seo My Ty in the core zone. It partially showed the inadequate sanitation facilities and poor hygiene of ethnic minority group in the HLNP. The fact that $80 \%$ of households sampled in Ta Van Giay 1 and 53\% of households sampled in Ta Trung Ho village has toilet showed the improvement in sanitation and hygiene of highland community. The difference in housing condition is due to (i) tradition of Red Dao which is large house, house of Black H'mong is small and short, (ii) Red Dao ethnic group manage income better than H'mong for increasing living condition and future spend, (iii) they protect forest better than H'mong (Key informant) and timber is available in their forest, (iv) saving management and (v) effects of other factors such as tourism, sanitation and hygiene program... Red Dao ethnic earn the highest net cash income per year and save cash generated from cardamom cultivation for purchasing house amenities such as transportation, television, make or fix house and decoration inside house. Most of Black H'mong is weak at cash management. They often spend money fast when they earn cash and less saving for the future. Giay and Tay ethnic households which operate home-stay has to fix their house, plant some flowers in front of the house, build bathroom and toilet. Therefore, their housing condition is better than Black H'mong households.

Television for information channel and entertainment along with motorbike for transportation are main assets of households sampled in the HLNP. Refrigerators are mostly possessed by home-stay operators in Ta Van Giay1 village in the buffer zone. Use of agricultural machine is popular in the core zone more than the buffer zone. The number 
of amenities of Red Dao households located in the core zone and Giay households in the buffer zone of the HLNP is higher than two remaining Black H'mong village, meaning Ta Trung Ho villagers and Ta Van Giay villagers have better living condition. Sin Chai is probably the poorest village represented by limited asset possession and lowest total net cash income.

\subsubsection{Upland transect}

The general upland transect in the region according to an increase in elevation consist of river (Muong Hoa and Ta Trung Ho river), terraced in valley, house and home garden, terraced field where water available and/or upland fields for planting maize where water is less, hill top with forest cover and cardamom field under shade of natural forest. Terrace is typical for Sapa district in particular and Lao Cai province in general whereas the model of paddy-home garden - upland fields - forest is common in mountainous areas of Vietnam.

In Seo My Ty village in the core zone where 17 hectares of flat paddy field was loss in Seo Trung Ho hydroelectricity project, the Upland transect is simpler. Agro-ecological zones are lake, few paddy, home and house garden, cardamom under forest canopy. Local grow little maize in their home garden or sloping fields which are far from their house.

\subsubsection{Agriculture production of local people in the HLNP}

Our study found that local people in both zones of the HLNP depend on national park land area to do sedentary agriculture for their subsistence. Their cropping system includes rice production in terraced fields, maize and/or cassava in sloping fields and home garden with diverse kinds of other crops and several fruit trees adjacent to their houses. Livestock are raised with small number in which big livestock are often released to paddy fields after harvest and released in forest or kept in wooden pen in rice/maize season to prevent crop damage.

Mono-cropping of wet rice on terraced field for subsistence is the dominant cropping system of local people in Hoang Lien national park. Traditional crop variety and hybrid variety are used in both zones of the HLNP. Rice grain yield in the Northern Mountain in Vietnam is about 4.55 tons/ha and average rice cultivated area was $400 \mathrm{~m} 2 /$ capita (Pham, 2011). Result of our study means rice grain yield in the HLNP is similar to rice grain yield of Northern Mountain in Vietnam. Rice cultivated area per capita in both zones of the national park is much higher than the average rice cultivated area in the North of Vietnam. Different from rice production in delta areas, local in the HLNP can cultivate one crop season per year due to climatic condition and topography. Moreover, the people density and the fertility rate are high. Thus, $40 \%$ households in the core zone and $50 \%$ households in the buffer zone do not have enough rice for home consumption and purchase rice for home use. Hunger period is from February to June when the new crop season starts.

In case of Seo My Ty village where local lost 17 hectares of paddy rice and denied to cultivate on low productive land given by the project, coping strategies is purchasing land from other adjacent areas for cultivation despite the fact that purchased terrace bring lower rice grain yield than their old flat paddy fields. Poor households work off-farm and nonfarm for generating cash income to purchase rice for home consumption. Households which lack of rice accounts for $80 \%$ of total household sampled in Seo My Ty village. It is possibly explained by low rice grain yield, big household size and small rice cultivated area. Weakness in cash management is popular in many areas of Vietnam when rural 
community contribute land to projects (project of building factory, electric-hydrology, recreational areas..) and suddenly own large amount of money. Rural has low awareness of importance of agricultural land. They spend money very fast on shopping and opening party instead of purchasing new cultivated area. Therefore, later, these households have very small rice cultivated area or have no paddy land.

Sloping fields was the results of forest clearance and shifting cultivation of ethnic minority groups living in both zones of the HLNP. Crops suitable for sloping fields are mostly maize, cassava which does not require much water in growth and development. Cultivation on sloping fields primarily depends on open water.

With regard to livestock, raising livestock in the HLNP has small scale. Big livestock are raised for draught power whereas small livestock are raised for home consumption. Raising hybrid pig for selling is available in villages of Giay and Tay ethnic group. It means households living in the buffer zone and near the communal road raise small livestock follow market-orientation. In contrast, households located in the core zone where transportation and market condition is limited, livestock are primarily raised for subsistence. That explained our finding that number of big livestock and chicken in the core zone are statistically significant higher than those in the buffer zone. Fishpond is limited in the study area with a few varieties suitable for cool weather. In both zones, livestock face problems of disease spread and death due to severe cold weather. It reduces interest of local people in raising livestock.

\subsubsection{Forest-based livelihood activities of local people in HLNP}

The study showed that local people living in both zones of the HLNP are highly dependent on forest resource. Households with low access forest frequency (several times per year, per month) probably go to forest for extracting fire wood and bamboo for home use. In contrast, households which extract timber and NTFPs go to forest more often such as several times per week or every day in off crop season. Community in the core zone extracts forest resources more than community in the buffer zone because their forest access is more often.

One hundred percent of local people extract firewood from the HLNP for heating and cooking. One limitation in our study is that firewood consumption was not estimated. Another research in Bach Ma National park in Vietnam found that ethnic group living there use from 6.1 to $21.3 \mathrm{~kg}$ firewood per day (Le et al., 2002). Twenty kilos of firewood corresponds to $0.08 \mathrm{~m} 3$ (Eve, 1997). Assume that amount of firewood use in HLNP equals to that of Bach Ma National Park. It is possible to estimate that each household in HLNP use from $0.03 \mathrm{~m} 3$ to $0.09 \mathrm{~m} 3$ firewood daily and from $8.9 \mathrm{~m} 3$ to $31.03 \mathrm{~m} 3$ fuel wood annually. In total, 4362 households located in HLNP consume at least $38821 \mathrm{~m} 3$ and maximum of $135352 \mathrm{~m} 3$ fire wood per year. Using purchased firewood from outside the HLNP and gas decrease this amount of consumption. Moreover, it also reduces NTFPs collection during firewood extraction. Another finding is that local people in the HLNP does not consider selling firewood as one cash income generating activity. It reduces pressure on extracting firewood in the national park.

Cardamom cultivators extract firewood for processing cardamom. The conversion ratio from fresh cardamom to dry cardamom of 3 to 3.5 found in our study is similar to finding of SNV (2011) which is $100 \mathrm{~kg}$ fresh fruit corresponds to 30kg dried capsule. However, estimation of firewood consumption in drying cardamom of respondents in our study is 
much different from the finding of SNV (2011) (1m3 of wood is consumed for processing 1.2 tons of fresh cardamom versus 3 tons of fresh cardamom, respectively). The HLNP has 1787 ha of cardamom planted under the canopy of natural forest corresponds to 3574 tons of dried cardamom. According to estimation of SNV, $3574 \mathrm{~m} 3$ of wood was consumed to dry cardamom in HLNP. The processing cardamom oven built by Red Dao ethnic minority group is more efficient in energy consumption than that of Black H'mong ethnic minority group.

Local people use firewood because of several reasons. First, it is their convention. Using firewood for cooking and put meat of livestock on the frame above the cooker to make it dry helps preserve meat for a long term use. It is very important in mountainous area which is far from market. Second, majority of local people use firewood because cannot afford other kinds of energy for cooking such as electricity and gas.

The study showed the relationship between poverty and timber/NTFPs extraction in the HLNP. Poor households extract forest resources for selling more often than other households although it's strictly prohibited in the HLNP. It is among five main context of forest dependency in Vietnam which was identified by O'Reilly (2005) that "in all rural areas of the country, a considerable number of poor people obtain either occasional income or employment from the collection, transport, processing and/or trading of forest products for local markets...". Consumption of forest resources extracted or selling them for generating cash income meaning that livelihood activities of local people in the HLNP also depend on maintaining these species for long-term benefit (Salafky and Wollenberg, 2000). At present, forest resource in the HLNP becomes scarce. Local people go longer trip and spend longer time to access forest to extract firewood and NTFPs. Big animals are rarely seen in the national park, even fish in stream is also limited.

\subsubsection{Tourism-based livelihood activities in the HLNP (home-stay and handicraft)}

Tourism based livelihood activities contribute 14\% to the total net cash income in the buffer zone and $0.4 \%$ to the total net cash income in the core zone. Development of tourism helped create a market for local products and non-farm products (Nyaupane and Poudel, 2011). Local in adjacent villages go to market in Sapa town to sell their agricultural products, handicrafts and traditional food. Despite tourism does not develop in the core zone of the HLNP, whenever tourists pass by villages during going trekking, some local residents take the best use of that day to go follow them to sell hand-made products or carrying luggage for tourists to get cash income. Tourism provides job opportunities in tourism business for local residents (Nyaupane and Poudel, 2011).

Difficulties in these activities are competition of indigenous people in the HLNP and Kinh households in selling handicrafts and tragedy of the commons in operating home-stay. Lack of co-operation among home-stay operators in Ta Van Giay village along with mismanagement of community-based tourism Management Board in Ta Van commune leads to the reduction in profit of this livelihood activity through price reduction, food supply by travel agency. Moreover, food provided by travel agency in Sapa is a possible cause of disease spread in livestock of local people.

Tourism supply economic rationale for protection and conservation of natural resources in protected area (Wearing and Neil, 2009). Our research found that tourism indirectly reduced forest resources extraction through the reduction in forest access frequency. Hussain et al (2012) also concluded that tourism minimized pressure on forest. Local 
households which operate home-stay, produce/selling handicraft or guide trekking are busy with these new cash income generating activities. Instead of accessing forest for firewood extraction and NTFPs collection by purpose or by accident, these households buy firewood and gas for use. Households operating home-stay can enjoy food prepared for tourists and less rely on wild vegetables in forest. Several households in Ta Trung Ho village in the core zone use gas, meaning they are less dependent on firewood and improvement in living condition helps reduce frequency of forest access.

\subsubsection{Cardamom cultivation and its importance to rural livelihood in the HLNP}

Focus of our study is cardamom cultivation which was considered as one of biggest threats to biological conservation in HLNP (Oldfield and Swan, 2003). This forest farming activity is common in the HLNP because it requires extremely less cost for agricultural input while bring highest profit for local people. HLNP is established for biological diversity conservation; however, it has becomes an intensive commercial forest-farming area recently. The study showed that area of cardamom per household and per capita of core zone community is several times higher than those of buffer zone community. It is logical because cardamom is alternative cash-generating activity in the HLNP when Vietnam government banned opium plantation (Frontier Vietnam, 1999). Moreover, cardamom is suitable for grow in natural forest at high elevation which locates in the core zone and it was planted by Black H'mong and Red Dao ethnic group before the government banned opium cultivation. When cardamom had market and price increased, households take the best use of good forest area in the core zone for planting this spice. Black H'mong and Red Dao located in the buffer zone went to core zone to plant cardamom. At present, local also plant cardamom in young generating forest. The conflict between livelihood preservation and use is clear because the protected area has become the intensive commercial forest farming area of this spice. Cardamom is crop insurance of core zone community and a part of buffer zone community, however, the national park loss the forest ground cover due to weeding, biological resources are affected by firewood extraction and heat during processing and transportation of cardamom. Besides, local people also extract wild vegetables and animal by purpose and by accident during their stay in the forest for processing this spice for consumption.

Another finding of this study is that there is a positive relationship between cardamom cultivation and forest protection in the HLNP. Households planting this spice always keep big trees for shading. Their participations in preventing and extinguishing forest fire increases because they need to save their cardamom fields.

The study showed that cardamom cultivation is the most important cash-generating livelihood activity of local people in both core zone and buffer zone of the HLNP, especially the core zone where cardamom contribute two third of the total net cash income. It also provides highest profit compared to other kinds of crops due to extremely low investment in agricultural inputs (variety, fertilizer and pesticide). To the whole national park, cardamom share about $58 \%$ of total net cash income of local people. This result is consistent with findings of Cuong (2011) that cardamom share about 57\% in income portfolio of households in Sapa district, 58\% in Bat Xat district and 50\% in Van Ban district in Lao Cai province. Cash-income sources in the core zone is less than those in buffer zone, meaning the core zone community will be more vulnerable if cardamom cultivation is prohibited by state power. 
Moreover, the study provides a brief picture of types of households that plant cardamom in the HLNP and the economic loss of these typological household groups if cardamom is banned. Farm households in the HLNP are diverse in terms of household characteristics, land endowment, distance to market, livestock, net cash income and income diversification. It indicates that forest farming activity is defined by household labor force, forest access, endowment and income generated from other livelihood strategies. To almost households group, share of cardamom in total net cash income is in range from 39\% to $98 \%$ and it is the highest among livelihood strategies of those groups. To several groups, cardamom cultivation seems to be the only source of cash income. It means that these types of household are extremely high dependent on cardamom cultivation. Other groups are moderately dependent or low dependent on cardamom.

The poverty line of Vietnam in rural areas is 4.8 million VND/capita/year, meaning households having average income per capita per month lower than 400 thousand VND are considered poor household. If cardamom cultivation is prohibited in the HLNP, Group 2 which is poor due to cash income of 2.7 million VND/ capita/ year will lose $39 \%$ of cash income and become extremely poor. Group 4, 5 and 6 which have current cash income of 5.3 million VND/ capita/ year, 5.9 million VND/ capita/ year and 7.5 million VND/ capita/ year respectively will lose $85 \%, 92 \%$ and $92.5 \%$ of their cash income and change from non-poor to poor. Group 7 which have super cash income of 45.5 million VND per capita per year will be less affected because with high cash income generated from cardamom cultivation in one year and in long period, they could invest in other cash income generating activities using their saving. Group 2 is the least affected if cardamom cultivation is banned because of $9 \%$ share of cardamom in their total net cash income. Our hypothesis given at the beginning is correct. Cardamom brings highest profit and local livelihood will be seriously affected if the government prohibits cardamom cultivation in the HLNP.

Cardamom cultivation requires special environmental condition which is shady, good moisture, high elevation. Therefore, livelihood of these types of households depends on maintenance of cardamom species and maintenance of habitat for cardamom's growth and development. They are two linkages between livelihood and conservation in HLNP. Cardamom contribution does not only bring economic benefit for local but also increase environmental awareness of local in cardamom cultivated area.

However, threat of cardamom cultivation expressed in the clearance of forest ground cover which is the base of all ecological succession in forest area. Keeping timber trees to provide cardamom with forest canopy is related to tree protection more than biodiversity conservation. For sustainability of livelihood and conservation in the HLNP, it is necessary to provide cardamom cultivators in the HLNP with other potential cash-income generating activities which are less harmful to biodiversity to steadily reduce dependence of local people on forest farming.

\subsubsection{Potentiality of cash-income generating activities in HLNP and adjacent regions}

The study showed potentiality of alternative cash income generating activities available in the region which would be possibly developed to replace cardamom cultivation. Livelihood activities familiar with local such as growing traditional rice, vegetable and raising livestock, operating home-stay and selling handicraft are easier to adopt than livelihood activities not available in the region such as planting Atiso and raising dove. Each alternative activity has its own potentiality in term of production condition, market, 
expansion possibility and consistent with orientation of local development. Each potential livelihood activity is suitable for one or two types of cardamom cultivators. Success in introduction of each model to local requires careful investigation on preparation for production, during production and economic efficiency in several first years. Based on that, it is possible to strengthen strength, eliminate weakness, exploit opportunity and reduce threat of that model into minimum.

Comparison between characteristics of each cardamom cultivator group identified in previous sections and SWOT analysis of potential alternative activities, it is possible to identify the suitable alternative livelihood activities for each typological households groups as shown in Table 9.9. However, in practice, it requires to consider the interest of each household group in potential cash income generating activities identified in our study. It is possible that the household group has good condition to adopt but they have no interest in adoption.

\subsubsection{Is it possible to ban cardamom cultivation in the HLNP?}

Despite the fact that we have identified several potential alternative livelihood activities, it is difficult to replace cardamom cultivation by these activities in short period. The reason is that most cardamom cultivators consider cardamom as the most important source of cash income thanks for its profit and the most potential crops due to extremely investment in cost of seed-fertilizer-pesticide. It is also difficult to ban cardamom cultivation in the HLNP immediately because cardamom covered almost all natural forest areas and high quality young generation forest in the HLNP at present. What HLNP Management Board has done was prevention of expanding cardamom area in recent years through information channels. Trial of each plant/livestock model to local residents will last from 1 to 2 years for training participants (about 5 to 10 households per one selected village) and investigation along with success evaluation. When local see that other livelihood activities bring financial benefit, they will start doing those activities. They will steadily less focus on cardamom if those activities bring profit as high as cardamom does. In another way, replacing cardamom cultivation by another livelihood activity must start from Partially replacement of cardamom to Complete replacement of cardamom to reduce economic loss and prevent shocks. Local has experienced the change in plant cultivation from opium to cardamom in their history, therefore, they are able to become familiar with change in livelihood activities and adopt. The process may take from 5 to 10 years in the context of prohibiting cardamom in the HLNP step by step.

Another importance is local authority should pay attention on income diversification, but replacement. Number of cash income source increase helps reduce dependence of local people on cardamom production as well as reduce shock when cardamom crop yield reduce. Cardamom yield decreased in 2012 and 2013 due to long period of sunny and hail, which cause from $20 \%$ to $50 \%$ loss in harvest. Local farmers expect the harvest in 2014, therefore, they continue weeding cardamom at the end of 2013 after a bad harvest. At present, it is unsure about harvest in 2014, however, if bad harvest is continuous for several years, cardamom cultivators have to find alternative livelihood activities. Besides, even in good weather condition, cardamom is not productive when it's old. In the near future, cardamom cultivator will lose their annual profit because they can harvest capsule from productive cardamom plants only. 
Each alternative livelihood activity or each model is always suitable in one time interval, then, it will need to be change - similar to our case. It is dynamic and local community is able to find new production practices in different context of institution and environment (Husson et al, 2001 cited in Castella et al, 2002). Therefore, besides introduction of new model, it is essential to strengthen and develop current livelihood activities of local.

One problem which often happens in Vietnam rural areas is the over-control of adopting livelihood activities which brings high profit of local people. At the beginning when few households start these activities, the supply is smaller than the demand and households gain high financial profit. When other households also start these activities, the supply increases steadily and become higher than demand. It leads to the decrease in price and failure even dead weight loss of households which start later. Therefore, to prevent this, different models should be introduced in one village if possible. It also helps increase diversity of cash income generating activities of local community. In the other hand, information of agricultural production should be updated and inform local farmers timely. For example, information of disease spread in one village or in sub village should be informed early so that local in other villages/sub villages can prevent disease and sell their livestock.

\subsection{Conclusion}

The study gives comprehensive answers of three main research questions which are about (i) livelihood activities and resource use of local people living in the HLNP; (ii) reliance of local people on cardamom cultivation which negatively affect biodiversity conservation in the national park and economic loss when cardamom is banned by state power and (iii) potential alternative livelihood activities of local people in the region. Findings of this study will be a reference for the HLNP Management Board and local government in decision-making of banning cardamom cultivation, introducing agricultural and nonagricultural models in villages located in the national park and/or changing current management for sustainability of livelihood and conservation.

The first question refers to livelihood activities and resource use of local people in the HLNP. Local people in the HLNP are Black H'mong, Red Dao, Giay and Tay ethnic minority group Their dominant livelihood strategies are sedentary agriculture along with forest resources extraction for subsistence combined with several cash-income generating livelihood activities such as forest farming, selling wage labor and tourism-based livelihood activities. Despite cultivating cereal for home consumption purpose, about $45 \%$ of local community in both zones lack of rice. Cash generated are used firstly for purchasing rice. Local people access forest with different frequency from several times per week to several per month. $100 \%$ of local people extract firewood in HLNP for home cooking and heating and some kinds of timbers and NTFPs for both home use and market. Big animals are rarely seen in the national park. Forest farming or cardamom cultivation is the common livelihood activity of Black H'mong and Red Dao ethnic group located in both the core zone and the buffer zone of the HLNP whereas Giay ethnic group generate income from operating homestay for tourists, raising livestock include hybrid pig. Cardamom cultivation requires forest habitat and drying cardamom after harvest to reduce weight requires a large amount of firewood. During stay in forest for drying cardamom, local extract edible forest products such as wild vegetables and several kinds of small animals for consume if they find by accident. Besides these resource uses, forest is also the grazing area of big livestock, especially in villages in the core zone of HLNP. Never the less, local people underestimate contribution of forest to their livelihoods due to limited awareness of 
forest ecosystem services.

The second research question refers to the importance of cardamom in livelihood of local people in HLNP. In both zones of HLNP, cardamom cultivation is the most important cashincome generating livelihood activity illustrated by its highest contribution to total net cash income of households. Share of cardamom in total cash income of households living in the core zone is $78 \%$ and double that one in the buffer zone in general. Buffer zone community has higher diversity of cash-income generating activities than core zone community. Forest resources extraction, raising livestock and tourism-based livelihood activities contribute about $34 \%$ to total cash income of households in the buffer zone which is about 5 times higher than that one of the core zone.

Construction of household typology clearly showed the importance level of this forest farming activity to local livelihood. Households which do not plant cardamom are mostly Black H'mong ethnic households staying in the core zone with land scarce or do not involve in agriculture and forest farming and Giay ethnic households in the buffer zone. These households will not be affected when cardamom cultivation is banned in the HLNP by the government. Households planting cardamom were divided in to seven groups which have different characteristics of demographic, agricultural and forest farming area, total land use are, distance to the closest agricultural input provider and to Sapa town, livestock system, total net cash income, cash income per capital and contribution of main livelihood strategies in total net cash income. Cardamom contribution to total net cash income of these groups are identified in range from $9 \%$ to $97 \%$, meaning these portion will be loss if local farm households are forced to stop cardamom cultivation.

Group 1) Rich cardamom and livestock, diverse income sources. $44 \%$ of total net cash income is from cardamom.

Group 2) Poor household with land scarce and strong forest resources extraction. 39\% of total net cash income is gained from cardamom

Group 3) Land scarce, strong tourism based livelihood activities. 9\% of total net cash income is generated from cardamom cultivation.

Group 4) Rich paddy and local livestock. Cardamom contributes $85 \%$ in total net cash income.

Group 5) Small farm holder. $92 \%$ of total net cash income is from cardamom.

Group 6) Paddy scarce in core zone. $92 \%$ of total net cash income is from cardamom.

Group 7) Very rich paddy and cardamom in core zone. $98 \%$ of total net cash income is generated from cardamom.

Groups 4, 5,6 and 7 which are highly dependent on cardamom cultivation will be the most affected. Groups 1 and Group 2 which are moderately or group 4 which is lowly dependent will be less affected. The poor household group will be the most vulnerable.

With regard to change of livelihood activities if cardamom production is banned, only $10 \%$ of cardamom cultivators has their choice which are raising goat $(5 \%)$ and selling wage labor (5\%). 30\% had no answer and another 30\% will follow the arrangement of the government. $30 \%$ remaining believed that cardamom cultivation will not be banned.

In current situation, it is impossible to band cardamom cultivation in the HLNP because prohibiting cardamom cultivation in the HLNP will create shocks and increase poverty. Poor households with land scarce will be the most vulnerable. Rich households depend totally or extremely high on cardamom, however, if cardamom is banned, they are not the 
most vulnerable group because they could use their strong financial capital to invest in new livelihood activities. It requires to diversify cash income sources of local people, especially local people in the core zone who have large cardamom cultivated areas and highly dependent on this kind of spice, through improving current livelihood activities and introduction along with adoption of new cash income generating activities.

The third research question refers to possibility to find potential alternative livelihood activities in the region. The study gave results that alternative livelihood activities are available in the HLNP and adjacent areas. It is possible to introduce these models to cardamom cultivator, however, each model has its own strengths, weakness, opportunity and threats and adoption of these models depend on suitability of each household group to those models. It is necessary to strengthen and develop alternative livelihood activities which are familiar to local community such as raising livestock, producing traditional rice and growing vegetable for market. To new livelihood activities such as raising dove or planting Atiso, it may take several years to introducing models to local and evaluate them. Local people will steadily change from cardamom cultivation to those alternative livelihood activities if they see economic benefits as well as advantages of those models although it may take a long time.

One again, prohibiting cardamom cultivation in the region is impossible. For sustainability of livelihood and conservation in the HLNP, it is necessary to partially reduce cardamom on forested land by constructing models of increase trees for shade and crop plantation around trees in several firsts year when canopy is not closed yet. Income diversification should be paid more attention than replacement to reduce dependence of households on a few cash-income generating activities. The success in reducing cardamom cultivation in the HLNP is related with the success in improvement current livelihood activities of local people, introduction and adoption of new livelihood activities. Improving agricultural practices to ensure food security is essential to decrease reliance of local people on limited biological resources in the protected area.

\subsection{Recommendation for livelihood improvement and conservation}

- Introduction of potential cash-income generating activities should be carried out as soon as possible because it takes local people several years to practice and evaluate. Poor households should be given priority because they belong to the most vulnerable group if cardamom is banned by state power.

- Training Black H'mong in building cardamom drying oven which save fuel energy is important because it contributes to reduce firewood extraction in the HLNP.

- Training local people to improve agricultural practices is important. Local people in the HLNP always cultivate plants using traditional practices, such as seeding vegetables and let it grow naturally without watering; then, plants may die or grow slowly and give low crop yield. It is essential if local people have basic knowledge of agricultural practices and produce enough vegetables for their consumption. It helps reduce extraction of edible plants in the forest of the HLNP.

- Support local community to grow grass for feeding livestock in food shortage season to develop raising livestock in the region. Suitable varieties for cool weather in the region are Pennisetum purpureum and VA 06. Releasing big livestock in forest for free grazing causes the HLNP to be threatened. Moreover, in winter season, livestock die in mountain which is 
far from house of local people due to severe cold weather or falling in to mountain side. The number of big livestock per each household is small, therefore, local should keep livestock in pen near their house, release them on paddy field in crop season and supply them grass in winter season.

- Some home-stay operators in Ta Van Giay village earn very little profit due to low number of guests $(<=7$ guests per year) and their alternative livelihood activities may have negative effects on biodiversity conservation. Meetings with participation of communal officers, community-based tourism management board and all home-stay operators in the village should be opened frequently to increase knowledge of operators on negative impacts of competition, especially travel agencies take the best use of that problem to reduce price, based on that, strengthen relationship among local home-stay operators. New price should be set up and ratified by Tourism Department and local government at different levels, then, informed to travel agencies in Sapa by legal documents. Another way is collect fee of tourists at the gate of the village to make sure all home-stay operators follow regulation of community-based management board in the commune.

-Handicraft and souvenir originated from China should be limited and prevented. Local people in the core zone can supply handicraft for sellers in the buffer zone and in Sapa town where tourists are crowded. In this case, both core zone and buffer zone community have more financial profit from tourism based livelihood activities.

- Training local people in the core zone about tourism-based livelihood activities should be paid attention in the near future when tourism projects develop in the core zone.

- Wage labors in the HLNP are often from poor households and highly dependent on forest resources extraction. Therefore, it is necessary to limit and prevent the immigration of people from other provinces to Sapa to work so that local ethnic minority group could find non-farm job, off-farm job for generating cash income.

- Improve education level of children at nursery school and primary school through bilingual teacher or combination between a Kinh teacher and a local person who has good education. It helps increase understanding of ethnic children and reduce drop out age, based on that, increase percentage of students at higher education levels and local with professional jobs in the future.

- Local people should grow some kinds of medical plants collected from forest around their house, in home garden to use when necessary. It reduces pressure on NTFPs in the HLNP.

- Guiding local people in spending cash and saving should be paid attention. Ethnic minority group always spend cash very fast on both basic need and recreation without saving for the future. Lack of skill in financial management after generating high amount of cash is one of reason for their disadvantage life cycle.

\subsection{Recommendation for further studies}

- Similar study on linking rural livelihood and conservation but in the part of HLNP belonging to Than Uyen district, Lai Chau province.

Two parts of HLNP (Lao Cai part and Lai Chau part) are separated due to Hoang Lien Son mountain range and local community in two locations may have different characteristic. A 
similar study in the second location in combination with this study will provide a whole view of the relationship between livelihood and conservation in the national park.

- Impact of cardamom cultivation on biodiversity

Cardamom is identified as one of biggest threats to biodiversity in the HLNP due to the production practices of local people which are removing ground forest cover for facility growth of cardamom. However, there has been not any study about how it affects. It is necessary to compare forest structure, species richness, biodiversity values and soil between natural forest and forested land with cardamom cultivation. This kind of study can be conducted in different districts in Lao Cai province, Lai Chau province, Ha Giang province. Cardamom species may be different among locations.

- Study on medical plants in the HLNP and its value chain

Medical plants are NTFPs in the HLNP. They are collected by local community for both home consumption and market. Biodiversity degradation in the HLNP lead to the reduction of medical plants. Study on availability of medical plants in the HLNP at present is very important for conserving these valuable species. It is also important to figure out natural medical plants in the forest and medical plants planted by people to get cash income.

- Impact of hydroelectricity projects on livelihood of local people in the HLNP

At present, there are two hydroelectricity factories in the HLNP called Seo Trung Ho and Su Pan 2. Several other hydroelectricity projects have been done on paper and will be carried out in the near future. Each project includes immigration of local people, construction of hydrological lake, dam, and factory along with pipe system. It causes both positive effect and negative effect on environment, livelihood of local community. Study on those impacts will be useful for decision-making of involved Departments about future projects and policy to minimize negative impacts on local.

\section{- Impact of tourism on livelihood of local people in the HLNP}

Previous studies on tourism always focus on Sapa which is one administrative unit of Lao Cai province including a part of the HLNP. Study on tourism but focus on two zones of the HLNP help supply information on potential to develop tourism in the national park for HLNP Management board. Among alternative livelihood activities which are not harmful to biodiversity, tourism-based livelihood activities have the highest potentiality because they are non-consumptive use of biodiversity. For example, if cardamom plantation requires forest habitat, forest land and firewood for processing and wild vegetables/animal consumption during processing, homestay service requires natural landscape and house amenities so that visitors can go sightseeing and relax. 


\section{References}

Adam, W. M., Aveling, R., Brockington, D., Dickson, B., Elliott, J., Hutton, et al. 2004. Biodiversity conservation and the eradication of poverty. Science, 306, 11461149.

Adger, W. N., Benjaminsen, T. A., Brown, K. and Svarstad, H. (2001). Advancing a political ecology of environmental discourses. Development and Change, 32, 681-715. Retrieved 3rd September 2013 from http://cstpr.colorado.edu/students/envs_5720/adger_etal_2001.pdf

Alther, C., Castell, J. C., Novosad, P., Rousseau, E., Tran, T. H. (2002). Impacts of accessiility on the range of livelihood options available to farm households in mountainous areas of northern Vietnam. In: (Castella and Dang Dinh Quang) Doi Moi in the Mountains. Land use changes and farmer's livelihood strategies in Bac Kan province, Vietnam. The Agricultural Publishing House, Hanoi, Vietnam. 121-146.

Amin, S. and Teerawichitchainan, B. (2009). Poverty, Gender and youth. Ethnic fertility differentials in vietnam and their proximate deternimants. Working paper. No. 18. the Populaion Council. ISSN: 1554-8538. Retrived 20th April 2014 from http://www.popcouncil.org/uploads/pdfs/wp/pgy/018.pdf

Baird, T. D., Leslie, P. W. (2013). Conservation as disturbance: Upheaval and livelihood diversification near Tarangire National Park, northern Tanzania. Global environmental change. http://dx.doi.org/10.1016/j.gloenvcha.2013.05.002

Barbier, E. B. (2005). Natural resources and economic development. Cambrige University Press. Page 13.

Bennett, N., Lemelinb, R. H., Kosterb, R. and Budkec, I. (2012). A capital asset framework for appraising and buiding capacity for tourism development in aboriginal protected area gateway communities. Tourism Management, 33 (4), 752-766.

Birdlife International. (2001). Hoang Lien Son-Sa Pa Nature Reserve. In: Sourcebook of Existing and Proposed Protected Areas in Vietnam.

BirdLife International in Indochina and MARD. (2004).Hoang Lien national park. Sourcebook of existing and proposing protected areas in Vietnam. Second edition. Hanoi. Retrieved 20 $0^{\text {th }}$ July 2013 from http://birdlifeindochina.org/birdlife/source_book/pdf/2\%20north\%20east/Hoang\% 20Lien.pdf

Biressu, A. N. (2009). Resettlement and Local Livelihoods in Nechsar National Park, Southern Ethiopia, thesis summited for Degree, University of Tromso, Norway.

Brown, K. (2012). Innovations for conservation and development. The geographical Journal, 168 (1), 6-17. 
Buckingham, J. S., Petheram, R. J. (2004). Cardamom cultivation and forest biodiversity in northwest Vietnam. Agricultural Research and Extension Network. Overseas Developmewnt Institute. Newsletter No. 50. Page 10. Retrieved 24th August 2013 from http://www.odi.org.uk/sites/odi.org.uk/files/odi-assets/publicationsopinion-files/5251.pdf

Byron, N. and Arnold, M. (1997). "What futures for the people of the tropical forests?". CIFOR Working paper No. 19: Bogor: Center for International Forestry Research (CIFOR).

Cao Van Sung (ed.) 1995. Environment and Bioresources of Vietnam: Present Situation and Solutions. The Gioi Publishers, Hanoi.

Carney, Diana. (1998). Sustainable Rural Livelihoods: What contribution can we make? Nottingham: Russell Press Ltd.

Carew-Reid, Jeremy, Josh Kempinski and Alison Clausen. 2010. Biodiversity and Development of the Hydropower Sector: Lessons from the Vietnamese Experience -Volume I: Review of the Effects of Hydropower Development on Biodiversity in Vietnam. ICEM - International Centre for Environmental Management, Prepared for the Critical Ecosystem Partnership Fund, Hanoi, Viet Nam. Retrieved 15th July 2013 from http://www.icem.com.au/docu ments/biodiversity/bioHPdevt/Volume\%20\%20Biodiversity\%20and\%20develo pment $\% 20$ of $\% 20$ hydropower-Vietna \%20experience.pdf

Castella, J-C., Dang, D. Q., Tran, D. L. and Le, Q. D. (2002). Scaling up local diagnostic studies to understand development issues in a heterogeneous mountain environment: An introduction to the SAM program. In: (Castella and Dang Dinh Quang) Doi Moi in the Mountains. Land use changes and farmer's livelihood strategies in Bac Kan province, Vietnam. The Agricultural Publishing House, Hanoi, Vietnam. 1-18.

Cernea, M. M., Schmidt-Soltau, K. (2003). Biodiversity conservation versus population resettlement: risks to nature and risks to people. Retrieved 31st August 2013 from http://www.cifor.org/publications/corporate/cd-roms/bonnproc/pdfs/ papers/T4_FINAL_Cernea.pdf

Chambers, R., \& Conway, G. R. (1991). Sustainable rural livelihood: practical concepts for the 21st century. Brighton: University of Sussex, Institute of Development Studies.

Child, B., Jones, B. (2006). Practical tools for community conservation in southern Africa, Participatory Learning and Action 55. Retrieved 20th August 2013 from http://pubs.iied.org/pdfs/14523IIED.pdf

Christensen, S.M., Tarp, P., \& Hjorts $\varnothing$, C.N.P. (2008). Mangrove forest management planning in coastal buffer and conservation zones, Vietnam: a multimethodological approach incorporating multiple stakeholders. Ocean \& Coastal Management, 51, 712-726. 
CPR Research and Development Group. (2007). Governance and Management of Common Pool Resources in Vietnam. Hue, Vietnam: Hue University of Agriculture and Forestry.

Dhakal, B., Pinard, M. A., Gunatilleke, I. A. U. N., Gunatilleke, C. V. S., Weerasingahe, H. M. S. P. M., Dharmaparakrama, A. L. S. and Burslem, D. F. R. P. (2012). Impacts of cardamom cultivation on montane forest ecosystems in Srilanka. Forest Ecology and Management, 274, 151-160.

Dietza, S. \& Adgerb, W. N. (2003). Economic growth, biodiversity loss and conservation effort. Journal of Environmental Management, 68, 23-35.

DFID (2000): Sustainable Livelihoods Guidance Sheets. Department for International Development. $\quad$ Retrieved 18th July 2013 from http://www.efls.ca/webresources/DFID_Sustainable_livelihoods_guidance_she et.pdf

Dudley, N. (Editor) (2008). Guidelines for Applying Protected Area Management Categories. Gland, Switzerland: IUCN. x + 86pp.

Eagles, P. F. J., McCool, S. F. and Haynes, C. D. A. (2002). Sustainable Tourism in Protected Areas: Guidelines for Planning and Management. IUCN Gland, Switzerland and Cambridge, UK. Xv + 183pp.

Frontier Vietnam (1999) Tordoff, A., Swan, S., Grindlry, M. \& Siurua, H.. (eds) Hoang Lien Nature Reserve.Conservation Evaluation 1997/98. Frontier Vietnam Environmental Research Report 17. Society for Environmental Exploration, UK and Institute of Ecology and Biological Resources, Hanoi.

Forest Science Institute of Vietnam (FSIV). (2009). Vietnam forestry outlook study. AsiaPacific forestry sector outlook study II. Working paper series. Working Paper No. APFSOS II/WP/2009/09. Retrieved $15^{\text {th }}$ July 2013 from http://www.fao.org/docrep/014/am254e/am254e00.pdf

Furze, B., De Lacy, T. and Birckhead, J. (1996). Culture Conservation and Biodiversity. Wiley. West Sussex.

Geist, H. J., Lambin, E. F. (2002). Proximate causes and underlying driving forces of tropical deforestation. BioScience, 52(2), 143-150.

Gezon, Lisa. (1997) Institutional structure and the effectiveness of integrated conservation and development projects: case study from Madagascar, Human Organization 56(4), pp. 462-470

Ghimire, K. B. (1994). Parks and people: Livelihood issues in national parks management in Thailand and Madagascar. Development and Change, 25 (1), 195-229.

Ghimire, K. B. (2008). Parks and people: Livelihood Issues in national Parks Management in Thailand and Madag ascar, published online on Wiley online Library. 
Jiren, T. S., Sen, L. C. and Overgaard, A. G. (2010). National park management and Local livelihood in Ban Suk Sam Ran, Thailand, thematic reports research, University of Copenhaghen.

Hausner, V. H., Fauchald, P., Jernsletten, J.L. (2012) Community-Based Management: Under What Conditions Do Sámi Pastoralists Manage Pastures Sustainably? PLoS ONE 7(12): e51187. doi:10.1371/journal.pone.0051187

Hens, L., Boon, E. K., (n.d.) Causes of biodiversity loss: a Human Ecological Analysis. Retrieved 28th August 2013 from http://www.multiciencia.unicamp.br/artigos 01/A1_HensBoon_ing.PDF.

Hoang, M. Q., Hoang, T. S., Truong, Q. H. (2005). Thực trạng quản lý rừng và ảnh hưởng của nó đến sinh kế người dân miền núi Thừa Thiên Huế (Trường hợp xã Phú Vinh, huyện A Lưới, Thừa Thiên Huế, Đề tài nghiên cứu của Trung tâm phát triển nông thôn Miền Trung, Đại học Nông Lâm Huế. Status of forest management and it's influence on livelihood of local people: Case study of Phu Vinh commune, A Luoi district, Thua Thien Hue province. Research of Center of development rural in Central Vietnam, Hue Universty of Agroforestry.

Honey, M. (2008). Ecotourism and Sustainable Development: Who Owns Paradise? (Second ed.). Washington, DC: Island Press. p. 33.

Hussain, S. A., Barthwal, S. C., Badola, R., Rahman, S. M. T., Rastogi, A., Tuboi, C. and Bhardwaj, A. K. (2012) An analysis of livelihood linkages of tourism in Kaziranga National park, a natural world heritage site in India. The International Journal of Protected Areas and Conservation, 18, 2, 32-44

ICEM. (2003a). Vietnam National Report on Protected Areas and Development. Review of Protected Areas andDevelopment in the Lower Mekong River Region, Indooroopilly, Queensland, Australia. 60 pp. ISBN: 097503324 7. Retrieved 21st June 2013 from http://www.mekong-protected-areas.org/vietnam/ docs/vietnam-pad.pdf

ICEM. (2003b). Lessons learned in Cambodia, Lao PDR, Thailand and Vietnam. Review of Protected Areas and Development in the Lower Mekong River Region, Indooroopilly, Queensland, Australia. 104 pp. Retrieved 31st August 2013 from http://www.mekong-protected-areas.org/mekong/docs/nlpintro.pdf

Kemp, N., Le Mong Chan \& Dilger, M. 1995. Nui Hoang Lien Nature Reserve. SEE Vietnam Forest Research Programme Technical Report No. 5. Society for Environmental Exploration, London. Retrieved 25th July 2013 from http://www.frontier-publications.co.uk/reports/Vietnam/EnvironmentalResear ch/NaluneReserves1994-2004/FVER05NuiHoangLien.pdf

Kiss, A. (2004). Is coomunity-based ecotourism a good use of biodiversity conservation funds? Treneds in Ecology and Evolution, 19 (5), 232-237.

Krantz, L. (2001). The Sustainable Livelihood Approach to Poverty Reduction: An Introduction. Retrieved 25 th July from http://www.forestry.umn.edu/prod/gro ups/cfans/@pub/@cfans/@forestry/documents/asset/cfans_asset_202603.pdf 
Lewis, C. (1996). Managing Conflicts in Protected Areas. IUCN, Gland, Switzerland, and Cambridge, UK. xii + 100 pp.

Kollmair, M. and Gamper, St. (2002): The Sustainable Livelihood Approach. Input Paper for the Integrated Training Course of NCCR North-South. Development Study Group. University of Zurich.

MacEwin, A., Nguyễn, T. U., Thẩm, N. D., Hà M. T., Simington, K. (2007). Sinh kế bền vững cho các Khu bảo tồn biển Việt Nam, WWF Việt Nam xuất bản. Sustainable livelihood for marine protected areas in Vietnam. WWF Vietnam Publish.

International Union for Conservation of Nature (IUCN). (1994). Guidelines for Protected Areas Management Categories. CNPPA with assistance from WCMC.IUCN, Gland, Switzerland.

Mbile, P., Vabi, M., Meboka, M., Okon, D., Arrey-Mbo, J., Nkongho, F., Ebong, E. (2005). Linking management and livelihood in environmental conservation: case of the Korup National Park Cameroon. Journal of Environmental Management, 76, 1-13.

McNamara, S., Tinh, D.V., Erskine, P.D., Lamb, D., Yates, D. \& Brown, S. (2006). Rehabilitating degraded forest land in central Vietnam with mixed native species plantings. Forest Ecology and Management, 233, 358-365.

MEA (2005). Ecosystems and Human Well-being: A Framework for Assessment. Introduction and Conceptual and framework. Washington, D.C., USA.

Ministry of natural resources and development (MONRE), 2008. 4th Country report. Vietnam's implementation on the biodiversity convention. Report to the biodiversity convention secretariat. Retrieved 30th July 2013 from http://www.cbd.int/doc/world/vn/vn-nr-04-en.pdf

Morris. J, Le Thi Phi, Ingles. A, Raintree. A and Nguyen Van Doung (2004). Linking Poverty Reduction with Forest Conservation: Case studies from Vietnam. IUCN, Bangkok, Thailand. 74 pp.

Minot N., Epprecht M., Tran Thi Tram Anh, Le Quang Trung, 2006 Income Diversification and Poverty in the Northern Uplands of Vietnam. International Food Policy Institute. Research Report 145:29.

Miles, M.B and Huberman, A.M. (1994). Qualitative Data Analysis,2nd Edition.Newbury Park, CA: Sage. 278 Pages.

Minh, T.T. (2009). Agricultural Innovation Systems in Vietnam's Northern Mountainous Region - six decades shift from a supply-driven to a diversification-oriented system. Margraf Publishers, Weikersheim, Germany, 260 Pages.

Nguyen, T. H., Nguyen, T. Q. H. and Tran, T. M. H. (2008). Territorial organization for ecotourism development in Hoang Lien national park, Sapa district, Lao Cai province. VNU Journal of Science, Earth Science, 24, 1-9. 
Nguyen Nhu Phuong and Stephen A. Dembner. (n.d.). Improving the lifestyles of people in protected areas of Vietnam. Retrieved 20th June 2013 from http://www.fao.org/docrep/v2900e/v2900e05.htm

Nyaupane, G. P., Poudel, S. (2011). Linkages among biodiversity, livelihood and tourism. Annals of Tourism Research, 38 (4), 1344 -1366.

Oldfield, S., Swan, S. (2003). Community based conservation of Hoang Lien Mountain ecosystem, Vietnam. Darwin Initiative for the Survival of Species. Annual report July 2001-April 2002.

O' Reilly, S. (2005). The utility of forest ethics. A proposed approach based on field work in Vietnam. Discussion paper. Retrieved 1st September 2013 from http://pubs.iied.org/pdfs/13506IIED.pdf

PARC Project, 2006, Policy Brief: Building Viet Nam's National Protected Areas System policy and institutional innovations required for progress, Creating Protected Areas for Resource Conservation using Landscape Ecology (PARC) Project VIE/95/G31\&031, Government of Viet Nam (FPD)/UNOPS/ UNDP/IUCN, Ha Noi.

Persha, L., Fischer, H., Chhatre, A., Agrawal, A., Benson, C. (2010). Biodiveristy conservation and livelihoods in human-dominated landscapes: Forest commons in South Asia. Biological conservation, 143, 2918-2925.

Pham Manh Cuong, 2005. Land-use change in the Northwestern Uplands of Vietnam. Empirical Evidence from Spatial Econometric Models and Geo-referenced Analyses and Policy Implications for Sustainable Rural Development. Thesis/dissertation. Gottingen: Cuvillier, 2005. Georg-August-Univ., Goettingen (Germany), 2005, 387 p.

Pham, V. T. 2011. Country report on rice cultivation practice: Vietnam. Prepare for Expert Meeting 2-3 June 2011. Bangkok, Thailand. Retrieved 25th April 2014 from http://www.jgsee.kmutt.ac.th/apnproject/Web_Postconference/pdf/8_Vietnam.p $\underline{\mathrm{df}}$

Pietrzak, R. (2010). F orestr y-Based Livelihoods in Central Vietnam: An Examination of the Acacia Commodity Chain: A Case from Thua Thien Hue Province, V ietnam. Theses and Dissertations (Comprehensive). Wilfrid Laurier University.

Salafsky, N., Cordes, B., Parks, J., and Hochman, J. (1999). Evaluating Linkages Between Business, the Environment, and Local Communities: Final Analytical Results from the Biodiversity Conservation Network. Biodiversity Support Program, Washington, D.C., USA. http://www.bcnet.org/bsp/bcn/results/analytical.pdf

Salafsky, N., Wollenberg, E. (2000). Linking livelihoods and conservation: A conceptual framework and scale for assessing the integration of human needs and biodiversity. World Development, 28 (8), 1421-1438.

Secretariat of the Convention on Biological Diversity (2004). Biodiversity issues for consideration in the planning, establishment and management of protected area 
sites and networks. Montreal, SCBD, 164 pages and i to iv. (CBD Technical Series no. 15).

SCBD. (2010). Linking Biodiversity Conservation and Poverty Alleviation: A State of Knowledge Review. CBD Technical Series No. 55. Retrieved 2nd September 2013 from http://www.cbd.int/doc/publications/cbd-ts-55-en.pdf

Secretariat of the Convention on Biological Diversity (SCBD). 2009. Sustainable Forest Management, Biodiversity and Livelihoods: A Good Practice Guide. Montreal, $47+$ iii pages. Retrieved 22nd July 2013 from http://www.cbd.int/development/doc/cbd-good-practice-guide-forestrybookletweb-en.pdf

Sekhar, N. U. (2003). Local people's attitudes towards conservation and wildlife tourism around Sariska Tiger Reserve, India. Journal of Environmental Management, 69, 339-347.

Sanjay, K. (2002). Involving Indigenous peoples In Protected Area management: Comparative Perspectives from Nepal, Thailand, and China.

Shanker K, Hiremath A, Bawa K (2005) Linking Biodiversity Conservation and Livelihoods in India. PLoS Biol 3(11): e394. doi:10.1371/journal.pbio.0030394

Sherbinin, A. D., Leah, K., VanWey, McSweeney, K., Aggarwal, R., Barbieri, A., Henry, S., Hunter, L. M., Twine, W., Walker, R. (2008). Rural household demographics livelihoods and the environment. Global Environmental Change, $18,38-53$.

SNV. (2008). Term of reference. Development of Sustainable Forest-Cardamom Management Mechanism for Poverty Reduction in Lai Chau and Lao Cai.

Stedman-Edwards, P. (1998). Root causes of biodiversity loss. An analytical approach (WWF-WorldWide Fund for Nature, Washington DC. 86 p.

Sunderlin, W., and Ba, H. (2005). Poverty Alleviation and Forests inVietnam. Bogor, Indonesia: Center for International Forestry Research (CIFOR).

Sunlu U. (2003). Environmental impacts of tourism. In : Camarda D. (ed.), Grassini L. (ed.). Local resources and global trades: Environments and agriculture in the Mediterranean region. Bari: CIHEAM, 2003. p. 263-270 (Options Méditerranéennes : Série A. Séminaires Méditerranéens; n. 57).

Tran The Lien. (2012). Role of forests in biodiversity conservation. Retrieved on 2nd August 2013 from http://vietnamredd.org/Upload/CMS/Content/ 20and\%20Events/15/Speech\%20on\%20biodiversity\%20- Tran\%20The\%20L iem \%20-\%20EN.pdf.

Shanker K, Hiremath A, Bawa K (2005) Linking Biodiversity Conservation and Livelihoods in India. PLoS Biol 3(11): e394. doi:10.1371/journal.pbio.0030394 
Tugault-Lafleur, C., Turner, S. (2009). The price of spice: Ethnic minority livelihoods and cardamom commodity chains in upland northern Vietnam. Singapore Journal of Tropical Geography, 30, 388-403.

Tumusiime, D.M., Vedeld, P. \& Gombya-Ssembajjwe, W. (2011). Breaking the law? Illegal livelihoods from a Protected area in Uganda. Forest Policy Economics, 13, 273-283.

Turner, S. (2007). Trading old textiles: the selective diversification of highland livelihoods in Northern Vietnam. Human Organization, 66(4), 401-416.

Twyman, C. (2001). Natural resources use and livelihoods in Botswana's Wildlife Management areas. Applied Geography, 21, 45-68.

United Nations (UN). (2012) The Millennium Development Goals Report 2012. United Nations, New York, USA.

United Nations Environment Programme World Conservation Monitoring Centre (UNEPWCMC). (2012). Protected Planet report 2012. Tracking progress towards global targets for protected areas.Retrieved 25th June 2013 from http://www.unepwcmc.org/medialibrary/2012/09/14/eb3bb854/PPR2012en.pdf

United Nations Population Fund (UNFPA). (2011). Ethnic groups in Vietnam: An analysis of key indicators from the 2009 Vietnam population and Housing Census. 63 pages. $\quad$ Retrieved 31st August 2013 from https://vietnam.unfpa.org/webdav/site/vietnam/shared/Publications\%202011/Et hnic_Group_ENG.pdf

Vietnam Department of Planning and Investment. (2012). Việt Nam: một số điển hình phát triển bền vững. Báo cáo tại Hội nghị cấp cao của Liên Hợp Quốc về Phát triển bền vững (Rio+20). Vietnam: Some typical cases on sustainable development. Report for United Nation Reference on Sustainable development (Rio + 20).

Vietnam Environmental Monitor (VEM), 2005). Biodiversity. Retrieved 31st August 2013 from http://siteresources.worldbank.org/INTEAPREGTOPENVIRONMENT/ Resources/VN_Env_Monitor_05.pdf

Vu Van Me and Le Thi Mong Phuong. (2010). Community forestry management for poverty reduction. Project final evaluation report. Oxfam Great Britain and Oxfam Australia. Retrieved 26th August 2013 from https://oaus.s3.amazonaws.com/wp-content/uploads/2011/12/eval-community forestmanage-vietnam-2010.pdf

Vu, T. N. (2012). Đánh giá thực trạng và đề xuất các giải pháp sinh kế bền vững cho cộng đồng ở Khu bảo tồn thiên nhiên Xuân Liên, tỉnh Thanh Hóa. Evaluation status and identify sustainable livelihood strategies for local community in Xuan Lien nature reserve, Thanh Hoa province. Master Dissertation Thesis. University of Natural Sience. Ha Noi. Viet Nam. 
Vuong, Q. H., Dam, V. N., Van Houtte, D., and Tran, T. D. (2011). The entrepreneurial facets as precursor to Vietnam's economic renovation in 1986". The IUP Journal of Entrepreneurship Development, VIII, 4, 6-47.

Wege, D. C., Long, A. J., May Ky Vinh, Vu Van Dung and Eames, J. C. (1999) Expanding the protected areas network in Vietnam for the 21st century: an analysis of the current system with recommendations for equitable expansion. Hanoi, Vietnam: BirdLife International Vietnam Programme

Wearing, S. and Neil, J. (2009). Ecotourim. 2nd edition. Printed and bound in Hungary.

West, P., J. Igoe and D. Brockington (2006). "Parks and Peoples: The Social Impact of Protected Areas." Annual Review of Anthropology, 35, 251-77.

World Bank (WB). (2004). Sustaining Forests: A Development Strategy. Washington, D.C.

World Bank (2009): Country Social Analysis-Ethnicity and Development in Vietnam. Summary Report World Bank, Washington D.C World Bank. Accessed on 15 August 2013 from http://siteresources.worldbank.org/INTEAPREG TOPSOCDEV/Resources/499760ESW0Whit1C10VietnamSummary1LR.pdf

World Bank in Vietnam, DFID, AcitonAid, Oxfam and Save the Children (1999) Participatory Poverty Assessment. Voice of the poor.

WWF. (2005). Towards an Effective Protected Areas Network in Africa. Experience in assessing protected area management effectiveness and future proposals.

Xuan Truong. (2012). Thảo quả - Giữ rừng hay phá rừng? Bản tin thời sự. Báo điện tử Dân Việt.http://danviet.vn/thoi-su/thao-quagiu-rung-hay-pharung/109237p1c24.htm Cardamom - destroy forest or protect forest? News on Current events. Online newspaper Dan Viet. http://danviet.vn/thoi-su/thao-quagiu-rung-hay-pharung/109237p1c24.htm

Youn, Y. C. (2009). Use of forest resources, traditional forest-related knowledge and livelihood of forest dependent community: Case in South Korea. Forest Ecology and Management, 257, 2027-2034.

Yonariza. 2007. Protected area and local livelihood: A study of people-forest interaction in Barisan I Nature Reserve, West Sumatra province, Indonesia. PhD thesis dissertation. AIT. 


\section{Appendix 1}

\section{Checklist for Key Informants Interview}

Date:

Interviewer:

Name:

Phone number

Age:

Gender:

Address:

Commune:

District:

Office:

Position:

\section{Village head}

1. Change in the last 30 years regarding kind of crop, variety, livestock, farm technology?

2. Farming calendar of current crops in the village?

3. Change in the last 30 years regarding forest area, species and size of trees in the forest?

4. Difficulties face by villages when forest loss?

5. Change in village before and after establishment of the Hoang Lien national park in term of food security, forest access and forest resource use?

Is there any regulation for extracting forest products?

How did land farm area change after establishment of HLNP?
a) Increased
b) Decreased
c) Constant
d) do not know
6. Has land allocation occurred in your village?
YES
NO

If yes, which year did it occur?

7. How was your land area change after land allocation?
a) Increased
b) Decreased
c) Constant
d) do not know

8. Support in agricultural production or other handicrafts in term of material, technical, financial? Which office support and when?

9. Do villagers want to expand area of cardamom in the future? How's about other crops?

10. What kinds of activities do villagers participate in management of HLNP? (Save forest from fire, Remove traps, join forest plantation, forest protection team...)

11. How often do local people participate in conservation activities of HLNP?

12. Did you open meeting with villagers living in core zone and buffer zone of the HLN and talk to them about forest protection?

\section{National park officers}

1. How is current forest system in HLNP?

2. What is current land use status in HLNP?

3. What are forest management activities in HLNP?

What are strengths and weakness of the park management?

4. What are major threats to HLNP?

How is development of farm land in the forest?

5. Is there any regulation regarding cardamom cultivation in the core of HLNP? Is it possible to ban cardamom cultivation in the core zone of the park?

If local people stop cardamom cultivation and engage in tourism, conservation of HLNP will be improved or not?

6. What are changes in the last several decades regarding NFTPs, tree species and size of tree extracted by different stakeholders? 
7. What are changes in tools and equipment used to cut timber/trap animal in HLNP in recent decades?

8. Is there any regulation regarding forest resources extraction and use in HLNP?

9. Is there any land use conflict occurred between park authority and local people?

Is there any land use conflict occurred between between villages?

10.Is there any illegal logging and/or hunting done by people inside village/outside village or strangers from other areas? And solution?

11. How did the management board of HLNP caught and punished those rule breakers?

12. What do you think about the existing policies and legal framework relating to HLNP management?

13. How effective is the law enforcement?

14. How can policies and legal framework improved?

\section{People committee officers}

1. Potential of developing tourism in villages in core zone of HLNP?

2. What tourism activity attracts tourists most?

3. How's about infrastructure in the village? (Roads, public lighting, telephones, internet, electricity, water, services: health, postal, etc.)

4. Are there any opportunities for local people generate income from tourism?

What can the local people produce and sell for tourists? (Traditional goods, agricultural products, handicraft products, ...)

5. Which national and/or international organizations are working in HLNP related to poverty alleviation, sustainable agriculture, sustainable development, tourism development? What are their supports for local households?

6. What are the strengths in the village for development of rural tourism?

What are the weaknesses in the village for development of rural tourism?

What are the opportunities in the village for development of rural tourism?

What are the threats in the village for development of rural tourism?

\section{NGO}

1. Which programs/projects does your office carry out in HLNP? (basic information about name, objective, sample villages, methods)

What do those programs/projects support local household?

Participation of local household in these projects?

2. Evaluation of these programs? What is the result?

3. Possibility to prolong these programs or carry out new programs in the future? 


\section{Appendix 2}

\section{Checklist for group discussion}

Group discussion will be organized in each village with the number of participants: 10 people, including:

1. Village head

2. Representative of Woman Union

3. Representative of Young Union

4. Representative of Elderly Union

and 6 farmers who are 35-50 years old.

Group discussion will focus on:

1. Participatory resource mapping

2. How cardamom cultivation affect forest resources of HLNP?

3. Farming system in the HLNP

4. Current farming calendar

5. What are potential agricultural products in HLNP?

It should be based on 4 criteria:

- It is suitable for ethnic minorities' producing condition

- Have potential market

- It is able to expand production toward market oriented

- It is consistent with the orientation of local development.

6. Strength, weakness, opportunity and threat of each alternative livelihood activity if local people adopt?

7. Conservation activities, willingness in participation of local people in conservation programs carried out by different offices/organizations in HLNP.

8. Support from government or NGOs to establish and implement programs of sustainable livelihood, introduction of new livelihood strategy and forest conservation in HLNP. 


\section{Appendix 3}

\section{Household Survey Questionnaire}

Interview number:

Survey questionnaire on

"Linking rural livelihood and conservation in Hoang Lien national park, Lao Cai province, Vietnam"

The purpose of this household survey is to collect information or the study said above. Information on livelihood of local people, like agricultural production, forest resources collection, contribution of each livelihood activity in household income and how people protect forest are collected. Please feel free to respond to the questions. All the responses will be confidentially treated and the information will be used only for academic purpose.

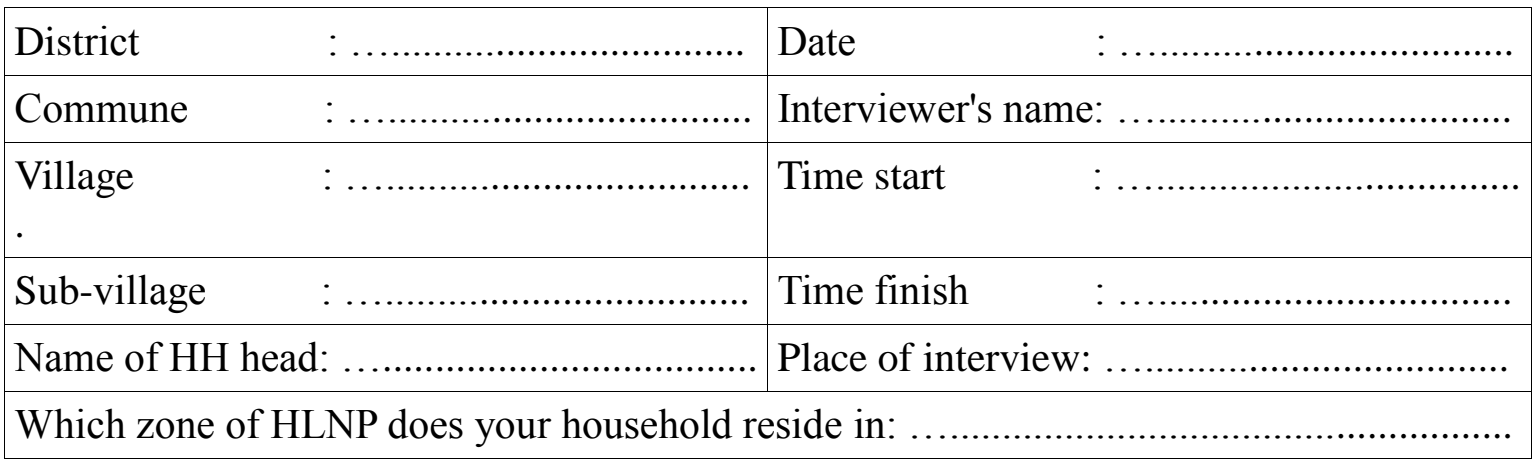

Distance to the nearest market where your household can buy necessities and sell agricultural products $(\mathrm{km})$

Distance to the Communal People committee:
Compound clustering: a) $<3$ houses
b) 3-10 houses
c) $>10$ houses

\section{Identification of household head}

1.1 Name:

1.2 Gender:

1.3 Age (year):

1.4 Ethnicity:

1.5 Original setters:

1.6 If not, place of origin:

1.7 Length of stay in this village of the household head:

1.8 Length of stay in this village of the household:

1.9 Main-occupation:

1.10 Sub-occupation:

1.11 Mobile phone number: 


\section{Household information}

Please mention who are the present members of your household

\begin{tabular}{|c|c|c|c|c|c|c|c|c|}
\hline No & \multicolumn{2}{|c|}{$\begin{array}{l}2.1 \\
\text { Name }\end{array}$} & $\begin{array}{l}2.2 \\
\text { Relationship } \\
\text { to HH head }\end{array}$ & $\begin{array}{l}2.3 \\
\text { Age } \\
\text { (years) }\end{array}$ & $\begin{array}{l}2.4 \\
\text { Gender }\end{array}$ & \multicolumn{2}{|c|}{$\begin{array}{l}2.5 \\
\text { Years of education }\end{array}$} & $\begin{array}{l}2.6 \\
\text { Main occupation }\end{array}$ \\
\hline \multicolumn{9}{|l|}{1} \\
\hline \multicolumn{9}{|l|}{2} \\
\hline \multicolumn{9}{|l|}{3} \\
\hline \multicolumn{9}{|l|}{4} \\
\hline \multicolumn{9}{|l|}{5} \\
\hline \multicolumn{9}{|l|}{6} \\
\hline \multicolumn{9}{|l|}{7} \\
\hline \multicolumn{9}{|l|}{8} \\
\hline \multicolumn{9}{|l|}{9} \\
\hline \multicolumn{9}{|l|}{10} \\
\hline & & \multicolumn{2}{|c|}{ Relationship } & \multicolumn{3}{|c|}{ Education } & \multicolumn{2}{|c|}{ Occupation } \\
\hline & & \multicolumn{2}{|c|}{ 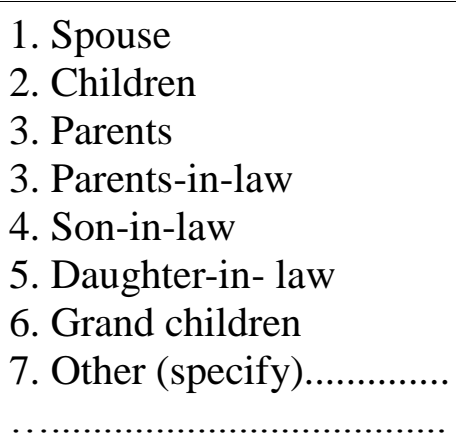 } & \multicolumn{3}{|c|}{$\begin{array}{l}1 \rightarrow 5 \text { years: Primary } \\
\text { school } \\
5 \rightarrow 9 \text { years: Secondary } \\
\text { school } \\
10 \rightarrow 12 \text { years: upper } \\
\text { secondary school } \\
\text { Vocational Training School } \\
\text { College } \\
\text { University }\end{array}$} & \multicolumn{2}{|c|}{$\begin{array}{l}\text { 1. Farmer } \\
\text { 2. Collect forest products } \\
\text { 3. Trader } \\
\text { 4. Household chore } \\
\text { 5. Government employee } \\
\text { 6. Farm product processing } \\
\text { 7. Other (specify) }\end{array}$} \\
\hline
\end{tabular}

\section{Housing condition}

3.1 What is area of your house? $(\mathrm{m} 2)$

3.2 What is ownership status of your house?
a) Own
b) Rent
c) Inheritance
d) Other (specify)

3.3 Does your household have Redbook for your house? YES

NO

3.4 What is the roof of your house made of?
a) Wood
b) Plant leave
c) Ceramic
d) Metalic
e) Other (specify)

3.5 What is the floor of your house made of?
a) Soil ground
b) ceramic
c) wood
d) Other(specify)

3.6 Does your household have electricity? YES 
3.7 What is source of energy for cooking in your household?
a) firewood
b) electricity
c) Gas (buy and pay money)
d) bio-gas of the family
e) Other (specify)

3.8 Does your household have a poor HH certificate from the village? YES NO In which year did your household receive that certificate?

\section{Household's properties}

Does your household have any of the following assets? If yes, please tell the number

\begin{tabular}{|l|l|l|}
\hline No. & $\begin{array}{l}4.1 \\
\text { Name of assets }\end{array}$ & $\begin{array}{l}4.2 \\
\text { Number }\end{array}$ \\
\hline 1 & Television & \\
\hline 2 & Refrigerator & \\
\hline 3 & Computer & \\
\hline 4 & Motorbike & \\
\hline 5 & Car & \\
\hline 6 & Truck & \\
\hline 7 & Ploughing machine & \\
\hline
\end{tabular}

4.3 What channels does your household use to get information of agricultural innovations?
a) Read Newspapers
b) Watch TV
c) Listen to Radio
d) Talk to HH head
e) Talk to people inside village
f) Talk to people outside village

g) Other (specify)

\section{Land pattern of the household}

\begin{tabular}{|c|c|c|c|c|c|c|}
\hline No. & $\begin{array}{l}5.1 \\
\text { Do you own this } \\
\text { type of land }\end{array}$ & $\begin{array}{l}5.2 \\
\text { Area (m2) } \\
\text { If areas cannot be } \\
\text { estimated, ask the } \\
\text { quantity of seed } \\
\text { that they grow on } \\
\text { each plot and write } \\
\text { detail here }\end{array}$ & $\begin{array}{l}5.3 \\
\text { Do you have } \\
\text { Red book for } \\
\text { that type of } \\
\text { land? } \\
1=\text { Yes, from } \\
\text { what year? } \\
2=\text { No }\end{array}$ & $\begin{array}{l}5.4 \\
\text { How } \\
\text { long do } \\
\text { you use } \\
\text { this land? } \\
\text { (years) }\end{array}$ & $\begin{array}{l}5.5 \\
\text { How far } \\
\text { from } \\
\text { your } \\
\text { house to } \\
\text { this land } \\
\text { area? } \\
\text { (walking } \\
\text { hours) }\end{array}$ & $\begin{array}{l}5.6 \\
\text { Current status } \\
\text { (planting crop, } \\
\text { planting tree, } \\
\text { grazing, give to } \\
\text { children, } \\
\text { another } \\
\text { household } \\
\text { rent...) }\end{array}$ \\
\hline 1 & Residential land & & & & & \\
\hline 2 & $\begin{array}{l}\text { Agricultural land } \\
\text { Upland fields } \\
\text { Paddy land } \\
\text { Home garden } \\
\text { Pasture land } \\
\text { Fish pond }\end{array}$ & & & & & \\
\hline 4 & Other (specify) & & & & & \\
\hline
\end{tabular}


5.7 Do you rent any land area? (Renting mean using land of another household and in return for periodic payment)

YES NO

If yes, what is the area of that type of land?

$(\mathrm{m} 2)$

What is its current use?

How long will you rent that land?

How much you have to pay for renting that land in one year?

Have you paid money for renting that land in this year? YES

\section{Cardamom cultivation}

In this part, I would like to ask you about cardamom cultivation of your household in this year. Because 2013 is not over, please estimate as best as you can about amount of harvest and price which your household expect to get in this year.

Does your household plant cardamom in this year? $\quad$ YES $(\rightarrow 6.1) \quad$ No $(\rightarrow$ section VII.)

6.1 Do you have cardamom cultivated area inside the boundary of the national park?

YES $\mathrm{NO}$

If yes, how many plots there? (plots), total area

And what is walking distance (hours) from your house to those cardamom plots.

6.2 Do you have cardamom cultivated area outside boundary of the national park?

YES $\mathrm{NO}$

If yes, how many plots there? .(plots), total area

And what is walking distance (hours) from your house to those cardamom plots

6.3 Do you have cardamom cultivated area on rented land?

YES

$\mathrm{NO}$

If yes, what is that area?

6.4 Do you plant any new cardamom in this year?

YES

$\mathrm{NO}$

If yes, how much money do you pay for variety? $(\mathrm{VND})$

6.5 What is the total cardamom area of your household at present?

6.6 How much money do you spend on providing fertilizer for cardamom in this year? (VND)

6.7 How much money do you spend on providing pesticide for cardamom in this year? (VND)

6.8 How much money do you spend on providing growth chemical for cardamom in this year? (VND)

6.9 Who are main household member involved in cardamom cultivation? 
6.10 Does your household hire any labor to plant/take care/ harvest/ transport cardamom? YES $\mathrm{NO}$

If yes, how much money does your household spend on hiring labor to plant/take care/harvest/ transport cardamom in this year (please estimate till the end of 2013)? $(\mathrm{VND})$

6.11 What is the total area of cardamom which your household harvests in this year?

6.12 What is the total amount of cardamom which your household harvests in this year? (kg fresh fruit).

6.13 What is the total amount of fresh cardamom fruit which your household sells in this year?. ..$(\mathrm{kg})$

What is the price? (VND/kg)

What is the total amount of dried cardamom fruit which your household sells in this year?. $(\mathrm{kg})$

What is the price? $(\mathrm{VND} / \mathrm{kg})$

What is the total amount of cardamom which your household keeps for homeconsumption? (kg fresh fruit) and/or (kg dried fruit)

6.14 How long has your household been selling dried cardamom? (years)

6.15 Where does your household dry cardamom?

a) Bring home and dry home using firewood

b) Collect firewood in HLNP and dry in the cardamom field

c) Collect firewood in HLNP and dry cardamom fresh fruit in the forest near cardamom field

d) Dry cardamom by sunlight on the field

e) Other (specify).

6.16 Please estimate how much firewood does your household collect for drying cardamom in one year?

6.17 Has your household bought firewood for drying cardamom in this year? YES NO

How much money did your household pay for firewood to dry cardamom in this year? (VND)

6.18 How do you sell cardamom?

a) Traders inside your village buy

b) Traders from outside go to your village and buy

c) You bring cardamom to market and sell

d) Other (specify)

6.19 Does your household have any support from extension services, agricultural office, national park officers or other organization in cardamom cultivation? YES NO If yes, please specify what kind of support, when, and it's effective 
6.20 Does your household have any support from extension services, agricultural office, national park officers or other organization in selling cardamom? YES NO If yes, please specify what kind of support, when, and its effective

6.21 Does your household intend to expand cardamom cultivated area? YES

Why?.

6.22 In which part of forest do you intend to expand cardamom now?
a) Deeply inside HLNP (in land of ....
village, near village)
b) In buffer area of HLNP (in land of village, near village)
c) Rented land (in land of.
..village, near village)
d) Other (specify)

6.23 Is your household worried that forested land will reduce in next 10 years? YES

NO

\section{Budget 2013}

I would like to ask you about cash income earned in 2013 from crops through activities related to crops of your household in 2013. Please estimate as best as you can the cash income you expected to earn by the end of this year

\begin{tabular}{|l|l|l|}
\hline $\begin{array}{l}\text { Now I will ask about cash } \\
\text { income earned in 2013. Please } \\
\text { estimate as best as you can the } \\
\text { cash income you expected to } \\
\text { earn by the end of this year }\end{array}$ & $\begin{array}{l}\text { W.2 } \\
\text { What will be the total revenue } \\
\text { incurred from this source of your } \\
\text { household in 2013? } \\
\text { Note: if farmer know net income } \\
\text { only, put net income here and put a } \\
\text { line through costs } \\
\text { (VND) }\end{array}$ & $\begin{array}{l}8.3 \\
\text { What will be the total costs such } \\
\text { as seed, fertilizer, pesticide and } \\
\text { hired labor, machinery for the } \\
\text { amount sold in 2013? }\end{array}$ \\
\hline & & (VND) \\
\hline & & \\
\hline & & \\
\hline & & \\
\hline & & \\
\hline & & \\
\hline & & \\
\hline & & \\
\hline & & \\
\hline
\end{tabular}


8.5 Have your household had to buy more rice for home consumption in this year? YES NO

If YES, how many $\mathrm{kg}$ of rice does your household buy in this year?

What is the price you have to pay? $(\mathrm{VND} / \mathrm{kg})$

8.6 Who sells crop products?

8.7 How does he/she sell it?

a) Traders inside your village buy

b) Traders from outside go to your village and buy

c) You bring cardamom to market and sell

d) Other (specify)

Source of Livestock income (if household earned cash income from livestock in 2013)

Now I will ask you about cash income earned in 2013 from livestock. As the year is not over, I would like you to estimate as best as you can cash income that you expect to earn by the end of the year.

\begin{tabular}{|l|l|l|l|}
\hline $\begin{array}{l}\text { Type of } \\
\text { livestock }\end{array}$ & $\begin{array}{l}\text { What will the total } \\
\text { revenue from this } \\
\text { [source] be in 2013? }\end{array}$ & $\begin{array}{l}8.11 \\
\text { What will the total cash income } \\
\text { from selling related } \\
\text { products/services, such as manure, } \\
\text { draught power, eggs or milk be for } \\
2013 ? \\
\text { (VND) }\end{array}$ & $\begin{array}{l}8.12 \\
\text { What will the total input cost for } \\
\text { the amount of [source] sold, } \\
\text { including estimates of feed value } \\
\text { and veterinary cost be in 2013? } \\
\text { (VND) }\end{array}$ \\
\hline & & & \\
\hline & & & \\
\hline & & & \\
\hline & & & \\
\hline
\end{tabular}

8.13 In case of emergency such as need money immediately for coping with shocks, does your family sell valuable household's properties and livestock? YES

\section{Income from forest resources in HLNP.}

8.14 What is the role of income from forest in your total household income in one year?
a) No means
b) Not much
c) Important
d) Very important

8.15 Does your household extract any forest resources in HLNP in 2013?

YES $\quad \mathrm{NO} \rightarrow$ next section 
8.16 What are activities related to forest extraction of your household in 2013

In case of timber, NTFPs and animal, please specify different species using local name

\begin{tabular}{|c|c|c|c|}
\hline $\begin{array}{l}\text { Type of forest } \\
\text { products }\end{array}$ & $\begin{array}{l}\text { 8.18 } \\
\text { Purpose of extract this product } \\
\text { 1. Home consumption only } \\
\text { 2. Selling only } \\
\text { 3. Mainly home consumption } \\
\text { 4. Mainly sell } \\
\text { 5. Other (specify) }\end{array}$ & $\begin{array}{l}8.19 \\
\text { What will the total cash } \\
\text { income from selling } \\
\text { products in } 2013 \text { ? } \\
\text { (VND) }\end{array}$ & $\begin{array}{l}8.20 \\
\text { What will the total input } \\
\text { cost for the amount of } \\
\text { [source] sold in } 2013 \text { (such } \\
\text { as hire labor, } \\
\text { transportation..) } \\
\text { (VND) }\end{array}$ \\
\hline Firewood & & & \\
\hline $\begin{array}{l}\text { NTFPs } \\
1 . \\
2 . \\
3 . \\
4 . \\
5 \ldots \ldots \ldots \ldots \ldots \ldots . . .\end{array}$ & & & \\
\hline $\begin{array}{l}\text { Timber } \\
1 . \\
2 . \\
3 . \\
4 . \\
5\end{array}$ & & & \\
\hline $\begin{array}{l}\text { Animals } \\
1 . \\
2 . \\
3 . \\
4 . \\
5\end{array}$ & & & \\
\hline
\end{tabular}

\section{Source of Tourism income}

8.21 Does any member in your household get cash/ in-kind from services related to tourism such as guiding tour, carry luggage for tourists, sell traditional products for tourists, allow them resting in house....? $\quad$ YES $\quad \mathrm{NO} \rightarrow$ section IX.

If yes, who are members involved?

What was the total cash income from these tourism services in 2013 ? (VND) 
Other activities of household in 2013 and related budget in 2013

\begin{tabular}{|c|c|c|c|}
\hline $\begin{array}{l}\text { Now I will ask about } \\
\text { cash income earned in } \\
2013 \text {. Please estimate } \\
\text { as best as you can the } \\
\text { cash income you } \\
\text { expected to earn by the } \\
\text { end of this year }\end{array}$ & $\begin{array}{l}8.22 \\
\text { Will your household } \\
\text { earn cash or in-kind } \\
\text { income from } \\
\text { [source] in } 2013 ? \\
\\
\text { YES } \\
\text { NO } \rightarrow \text { next source }\end{array}$ & $\begin{array}{l}8.23 \\
\text { What will be the total } \\
\text { revenue incurred from this } \\
\text { source of your household in } \\
2013 \text { ? } \\
\text { Note: if farmer know net } \\
\text { income only, put net income } \\
\text { here and put a line through } \\
\text { costs } \\
\text { (VND) }\end{array}$ & $\begin{array}{l}8.24 \\
\text { What will be the total } \\
\text { costs such as seed, } \\
\text { fertilizer, pesticide and } \\
\text { hired labor, machinery for } \\
\text { the amount sold in 2013? } \\
\text { (VND) }\end{array}$ \\
\hline \multicolumn{4}{|l|}{ Fruits (all) } \\
\hline \multicolumn{4}{|l|}{ Vegetables (all) } \\
\hline \multicolumn{4}{|l|}{ Roots (all) } \\
\hline \multicolumn{4}{|l|}{ Medical plant (all) } \\
\hline \multicolumn{4}{|l|}{ Aquaculture (all) } \\
\hline \multicolumn{4}{|l|}{$\begin{array}{l}\text { Off-farm jobs (work } \\
\text { for other household, } \\
\text { hauling timber and } \\
\text { NTFPs .... and get paid) }\end{array}$} \\
\hline \multicolumn{4}{|l|}{$\begin{array}{l}\text { Agricultural trade } \\
\text { such as resale of } \\
\text { agricultural } \\
\text { products, seed and } \\
\text { fertilizer trade }\end{array}$} \\
\hline \multicolumn{4}{|l|}{$\begin{array}{l}\text { Business } \\
\text { (shops in village or } \\
\text { outside village) }\end{array}$} \\
\hline \multicolumn{4}{|l|}{ Government aid } \\
\hline \multicolumn{4}{|l|}{ Retirement payment } \\
\hline Remittances/gifts & & & \\
\hline
\end{tabular}

\section{25 Rank source of income}

Which crops, livestock, forest products, off-farm or non-farm activity contributes the most, second most to income of your household? Please rank the 3rd, 4th and 5th one also.

\begin{tabular}{|l|l|l|l|l|l|}
\hline Level & $\begin{array}{l}1 \\
\text { contribute } \\
\text { highest }\end{array}$ & 2 & 3 & 4 & $\begin{array}{l}5 \\
\text { contribute } \\
\text { lowest }\end{array}$ \\
\hline Source & & & & & \\
\hline $\begin{array}{l}\text { Estimation of } \\
\text { contribution (\%) }\end{array}$ & & & & & \\
\hline
\end{tabular}




\section{Questions related to forest-based activities of local people in HLNP}

9.1 How often does your household go to forest to extract timber or collect other products in HLNP?
a) daily
b) several times per week
c) several times per month
d) seasonal, when
e) Other (specify)

9.2 How often does your household hunt animal or trap animal in HLNP?
a) daily
b) several times per week
c) several times per month
d) seasonal, when.
e) Other (specify)

How many of catch per year?

Your household sell these animals or use for home consumption?
a) Sell only
b) Home consumption only
c) Mainly sell
d) Mainly consumption

e) Other (specify)

9.3 What tools does your household use to cut timber?

9.4 Are there any people outside villages/communes go to extract timber NTFPs, animal in HLNP?

YES NO

9.5 Does your village, commune. District officers have any regulations/actions to stop them in your opinion? YES NO

If yes, what are those regulations

\section{Questions related to knowledge of local people on forest, forest protection, legal status in HLNP}

10.1 Do you think protect forest is necessary? YES NO Why?

10.2 Is there any team accounting for forest protection in your village? YES NO If yes, how many people are there in that team? ........................... (people) Do they have any benefit/support by cash, in-kind for their work? $\quad$ YES NO Have you or any member in your family participate in that team? NO

10.3 Is there any regulation for cutting timber and collect NTFPs, hunt animal in HLNP according to state law? 
10.4 Is there any regulation for cutting timber and collect NTFPs, hunt animal in HLNP according to your village law?

10.5 Does your family often joining the meeting organized by local authority or HLNP?
a) Never
b) Rarely
c) Occasionally
d) Normal
e) Often
f) Other (specify)

10.6 Does your family often joining the training course or workshop organized by local authority or HLNP?
a) Never
b) Rarely
c) Occasionally
d) Normal
e) Often
f) Other (specify)

10.7 How many times does your household join patrol the forest, communication campaign or prevent forest fire or any activities per year?
a) Never
b) Rarely
c) Occasionally
d) Normal
e) Often
f) Other (specify)

10.8 What is the reason for your participants in those activities?
a) Look interest
b) Asked by local authority
c) For getting benefits
d) Social obligation
e) Prevent its expansion
f)(specify)....

10.9 Has your household ever signed any agreement with HLNP about forest protection? YES NO

If yes, when did your household sign that agreement?

10.10 Have you or has any member of your household engaged in conservation project of the government such as forest plantation project? YES $\mathrm{NO}$

If yes, what was the project and what is your task in those projects?

10.11 Does your family receive support from extension service, forestry office, agricultural office or state company, private company in agricultural production, forest plantation?

YES NO

If yes, which kind of support did you receive (technical supports, financial support, subsidize seed, fertilizer, pesticide

How often do they help your household?

10.12 Have you or has any member of your household engaged in conservation project of the international project such as sustainable livelihood project? YES NO If yes, what was the project and what is task in those projects? 
10.13 Does your family receive support from international organization in agricultural production, forest plantation? YES

$\mathrm{NO}$

If yes, which is that organization?

Which kind of support did you receive (technical supports, financial support, subsidize seed, fertilizer and pesticide)

\section{Tourism in HLNP}

11.1 Have you or has any member in your household see tourists in your village? YES NO

If yes, how often do you or does any member of your family see them in your village?
a) several times per year
b) several times per month
c) several times per week
d) daily

e) Other: specify

11.2 Is there any hostel or house for tourist stay overnight in your village?
a) do not have
b) few
c) some
d) many

11.3 Have you or any member in your family engaged in tourism services?

YES NO

If yes, when did you or member in your household start?

in which service.

inside your village or in another village.

11.4 Do you think that tourism can help to increase your income or it can generate more employment opportunities? YES

NO

Why

11.5 Do you think that it is necessary to have trainings developing tourism in your village?

YES

NO

Why?

11.6 Is there any government office or national organization, international organization supporting your village in developing tourism? (For example: open free foreign language class, open co-operation to make handicraft products, introduction tourists for your village).

YES

$\mathrm{NO}$

If yes, please specify which office/organization and their support.

11.7 Are you willing to stop forest extraction activities to engage in tourism service/activities?
YES
NO

11.8 Are you willing to stop cardamom cultivation to engage in tourism services/activities? YES 
11.9 What are our difficulties if you or other members of your family engage in tourism for generating income?

\section{Additional questions}

A1. What do you think if the government use state power to force you to leave HLNP for conservation?

A2. Are you willing to leave HLNP and follow resettlement program of the government? YES

NO

Why?

A3. What do you do to protect forest to have canopy to grow cardamom?

A4. Is your household afraid that government will band cardamom like banning opium before? YES NO

Do you think it will happen? YES NO

A5. What does your household do for earn a living if the government ban cardamom cultivation?

A6. Is it easy to sell these products in your living area? (Specify to each product the respondent given above)

Thank you for your co-operation! 


\section{Appendix 4}

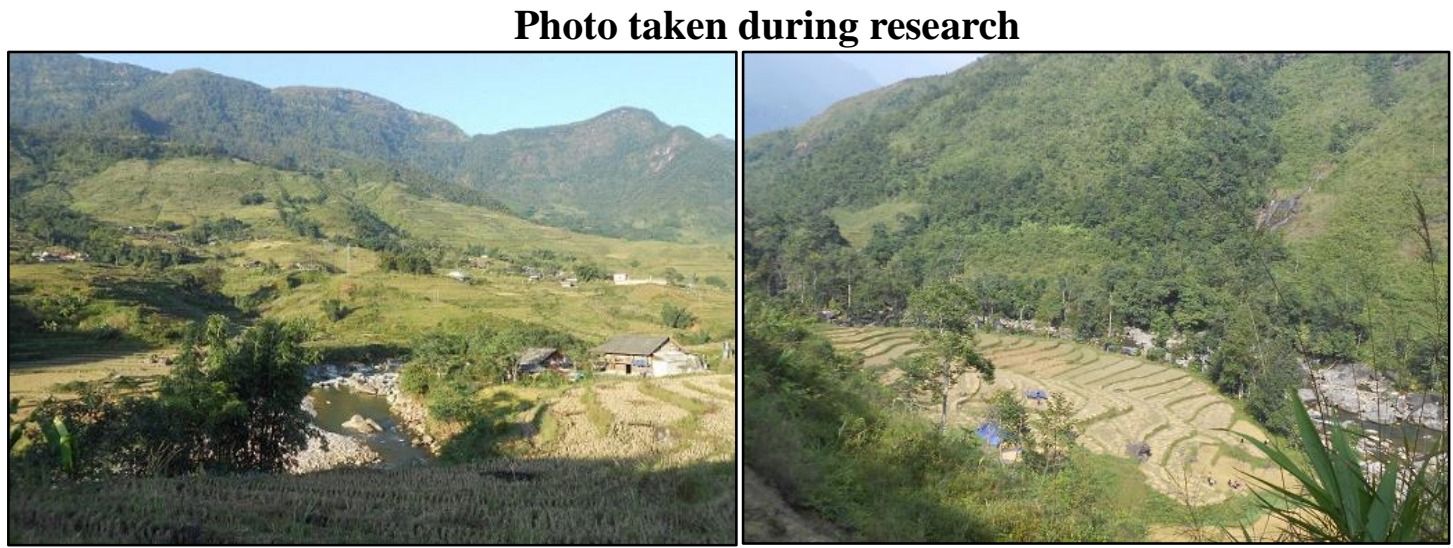

A view of land use in the buffer zone in the HLNP/ Paddy fields in the core zone of the HLNP
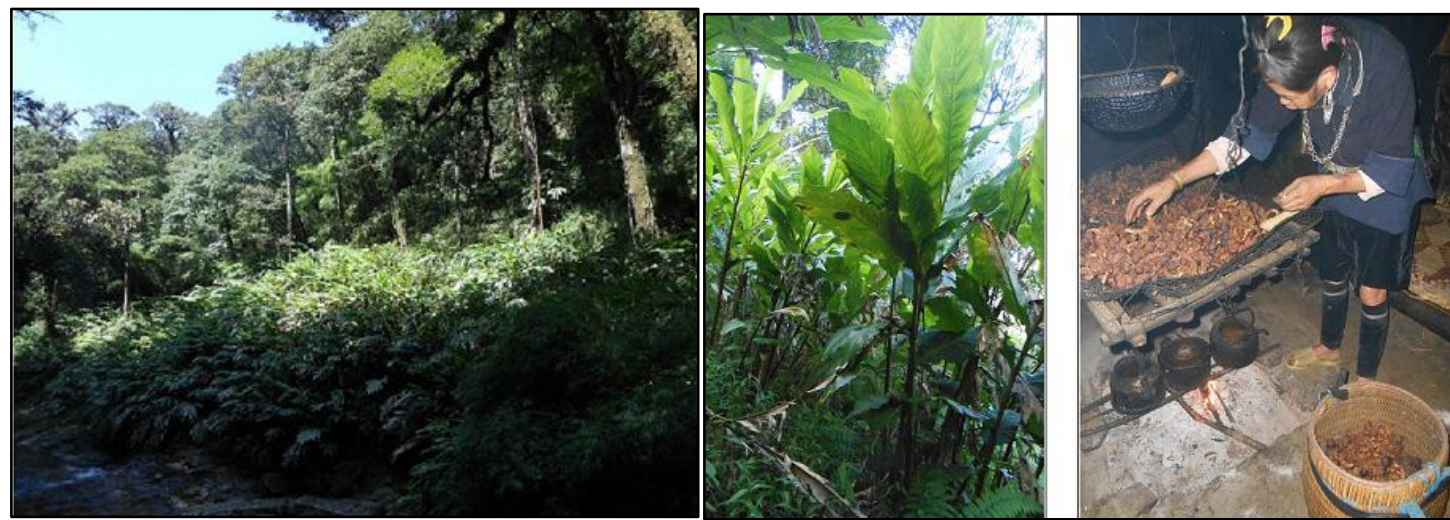

Cardamom is cultivated under forest canopy/ A H'mong woman dry a little cardamom at home
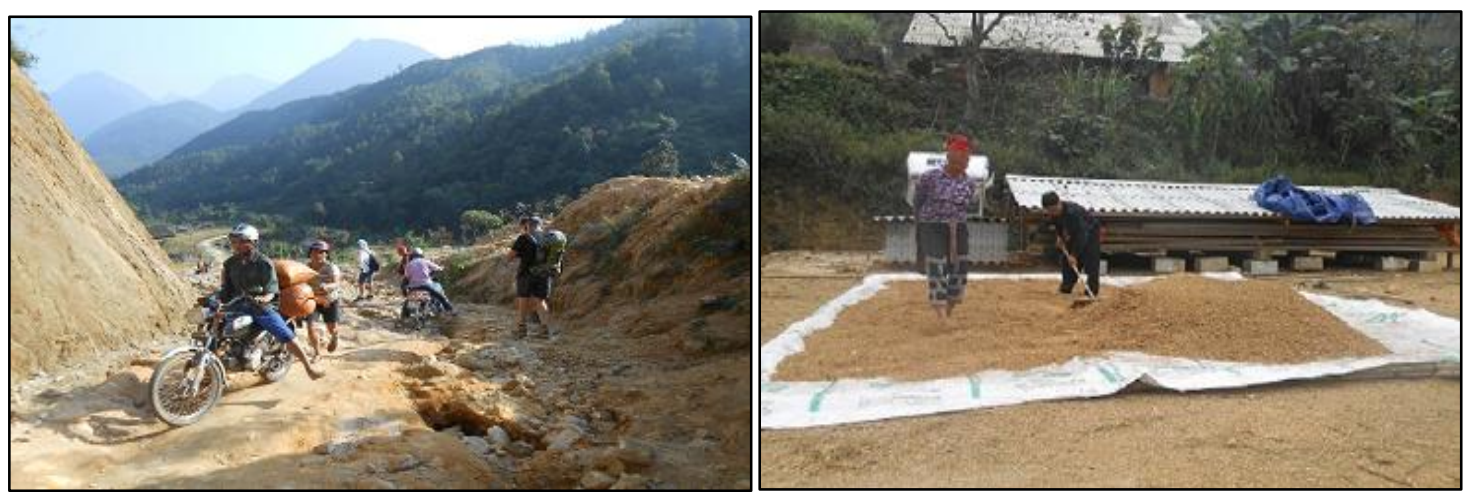

Transport cardamom to Sapa for selling / A Red Dao household in Ta Trung Ho village dry rice
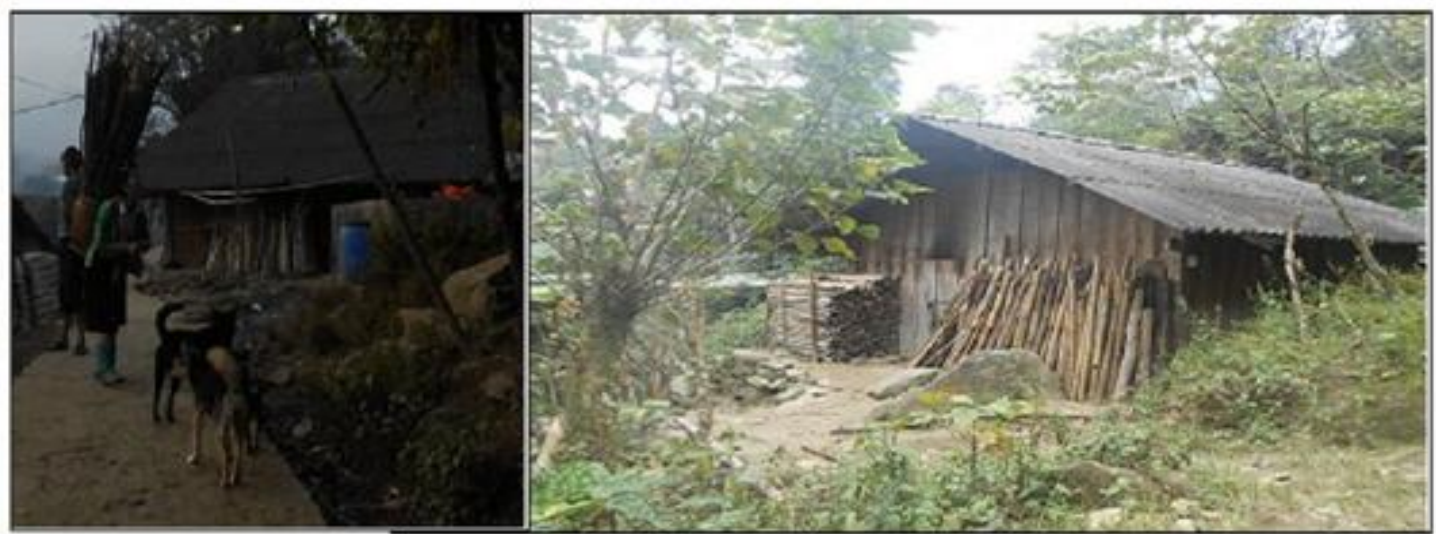

Firewood is collected and saved for use in long term 


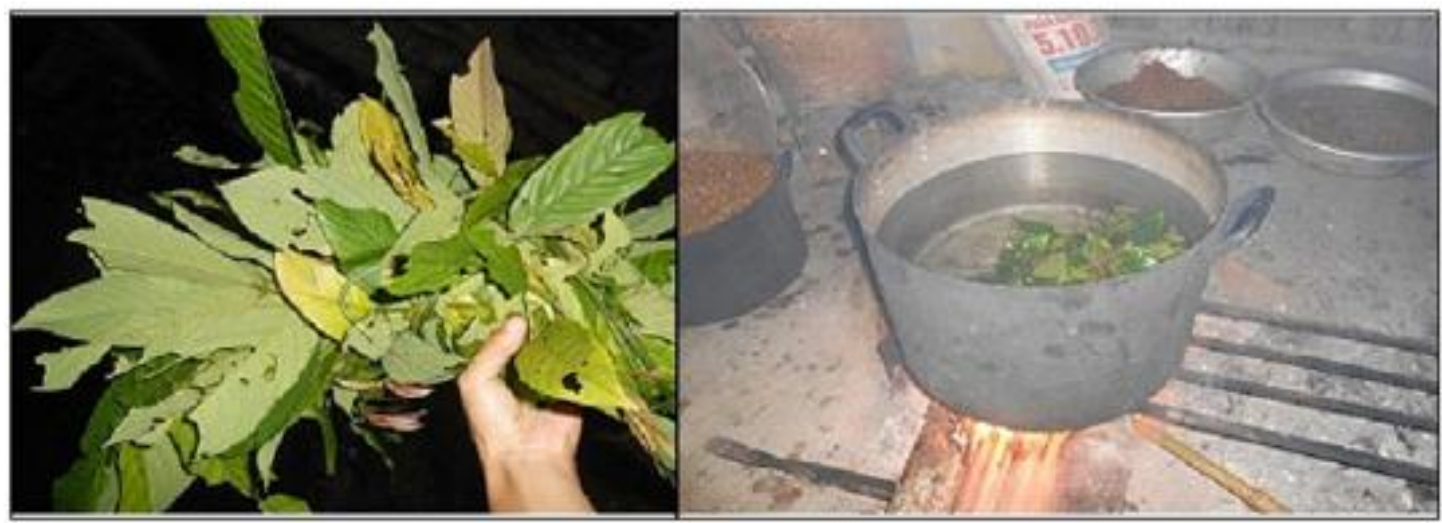

One kind of medical plant used for bathing by Red Dao ethnic group in Ta Trung Ho village in the core zone of the HLNP

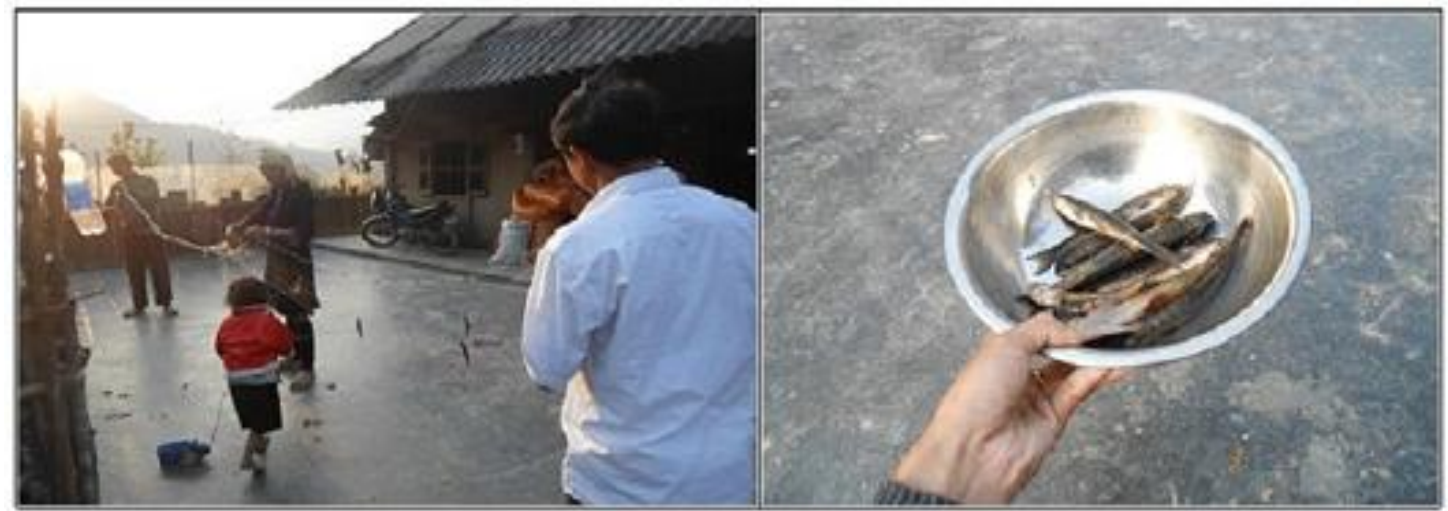

A household in Den Thang village in the core zone remove fish out of net. They put a net in streams several times per month and get some small fish for home consumption

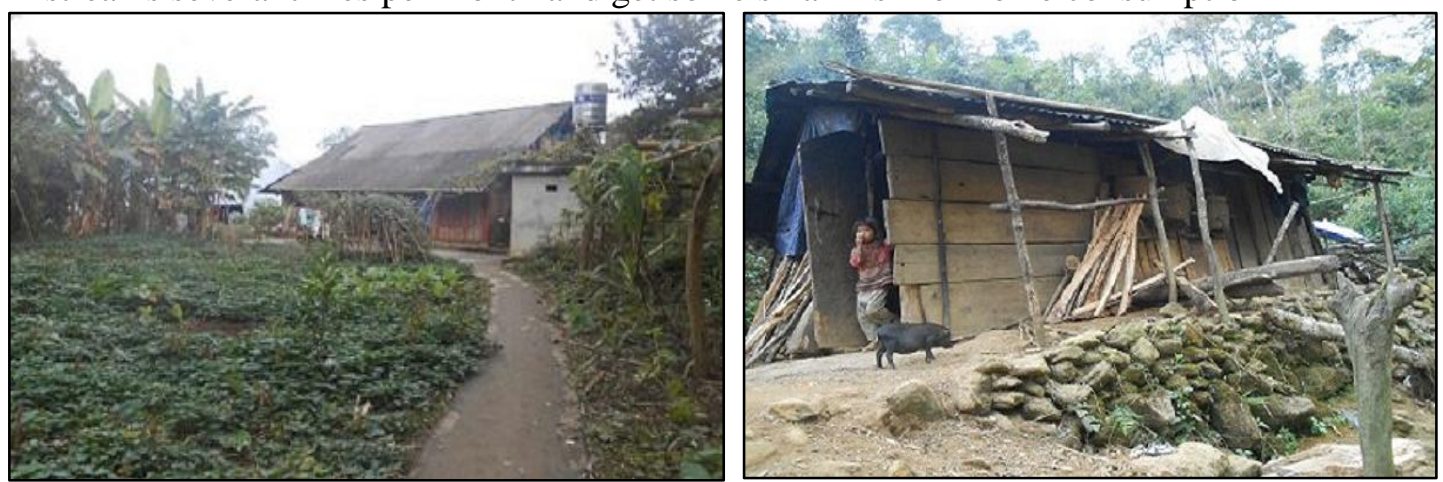

House of Giay ethnic group in the buffer zone/ House of a poor Black H'mong household in

Sin Chai village in the buffer zone $(16 \mathrm{~m} 2)$

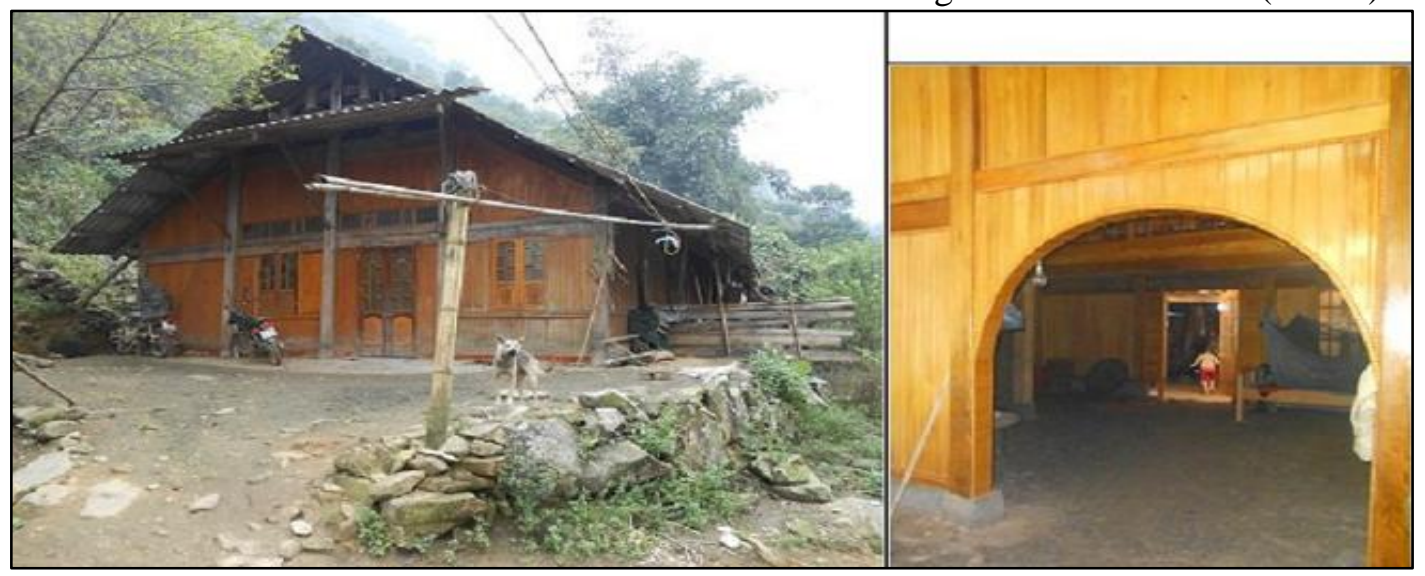

House of Red Dao ethnic group in Ta Trung Ho village in the core zone has glass window, bathroom, toilet and decorations inside house. 

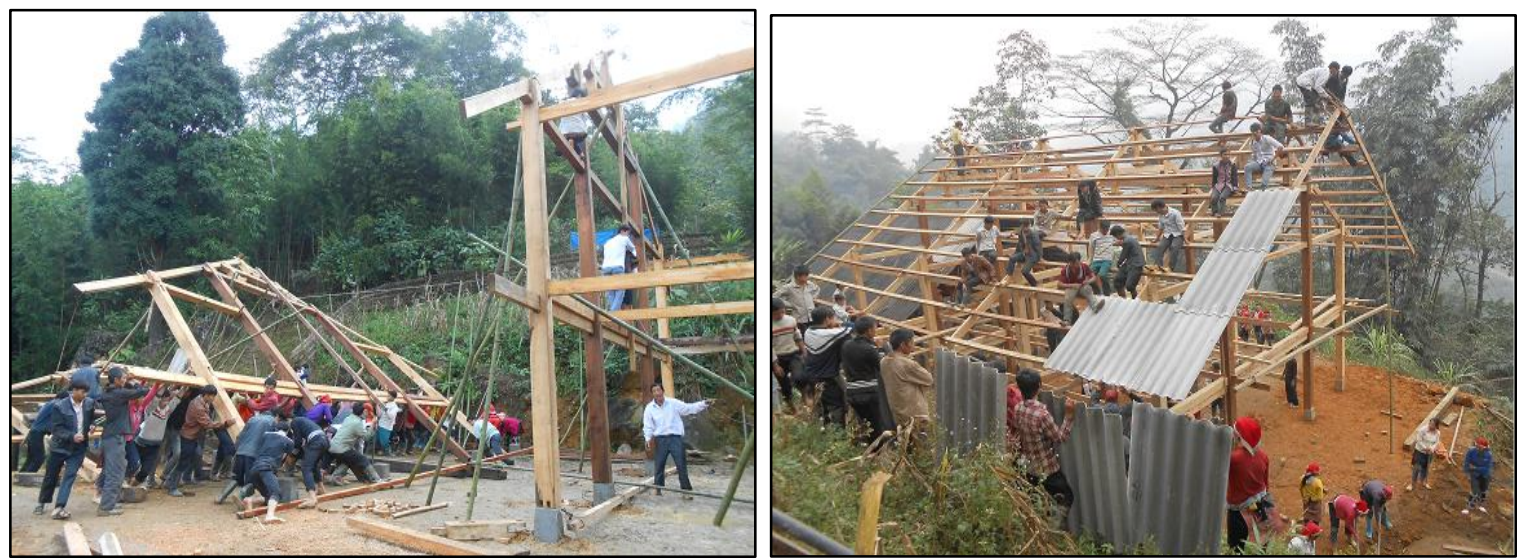

Making house in Ta Trung Ho village in the core zone with participation of 100 people in the village
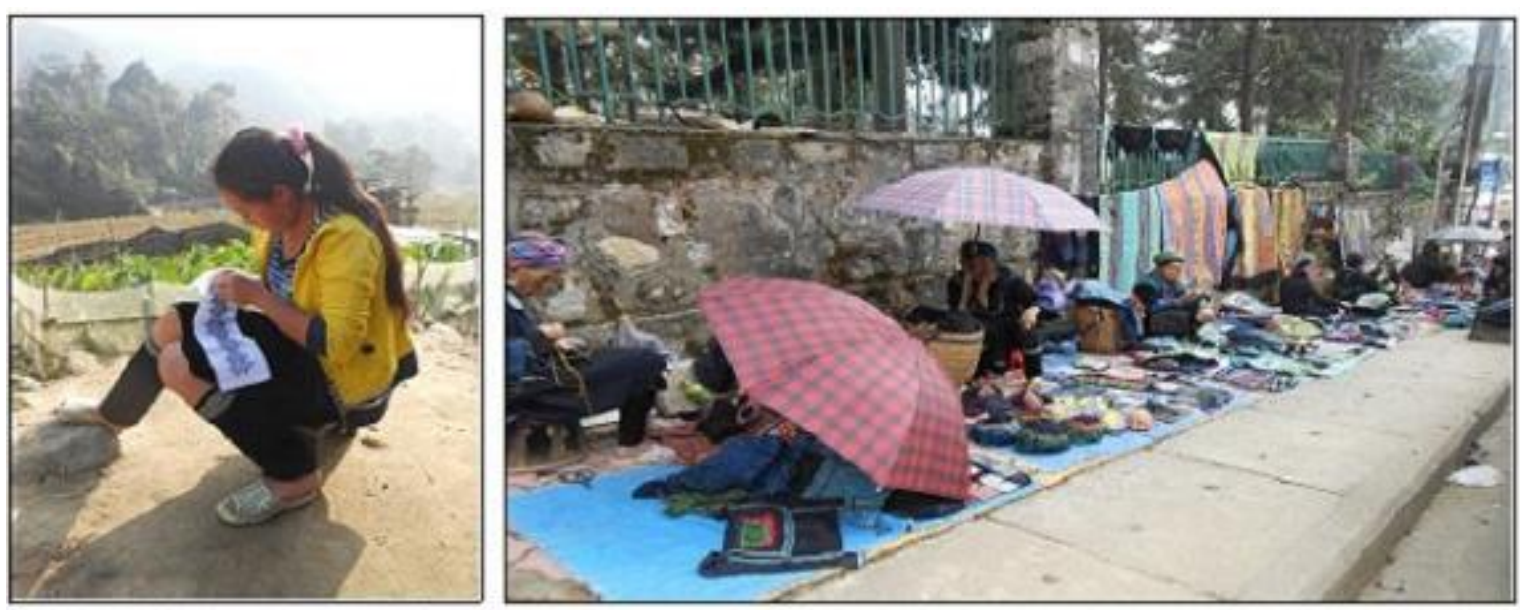

Local woman make handicrafts in their free time. H'mong woman sell handicraft products in Sapa town
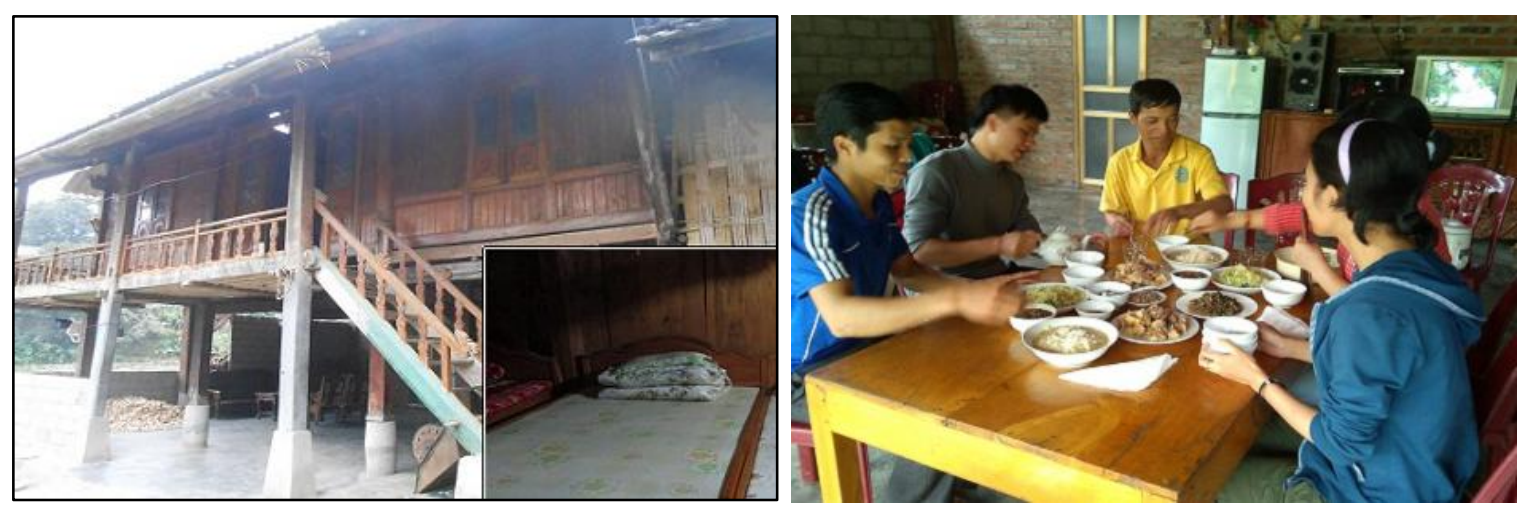

Home-stay operated by Tay ethnic group in Ban Ho commune. It is similar to home-stay operated by Giay ethnic group in Ta Van commune. Tourists can stay overnight and enjoy lunch and dinner with the family. 

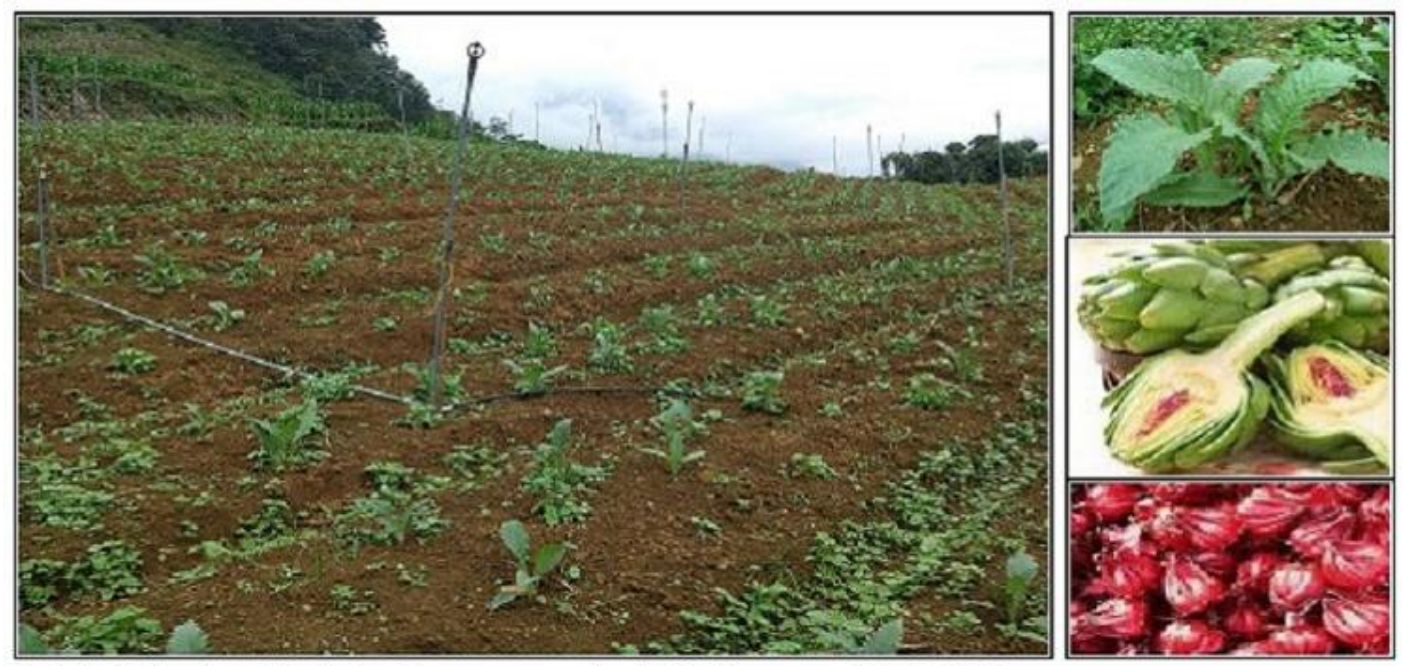

Model of Planting Atiso in Ta Van commune in the buffer zone of the HLNP.
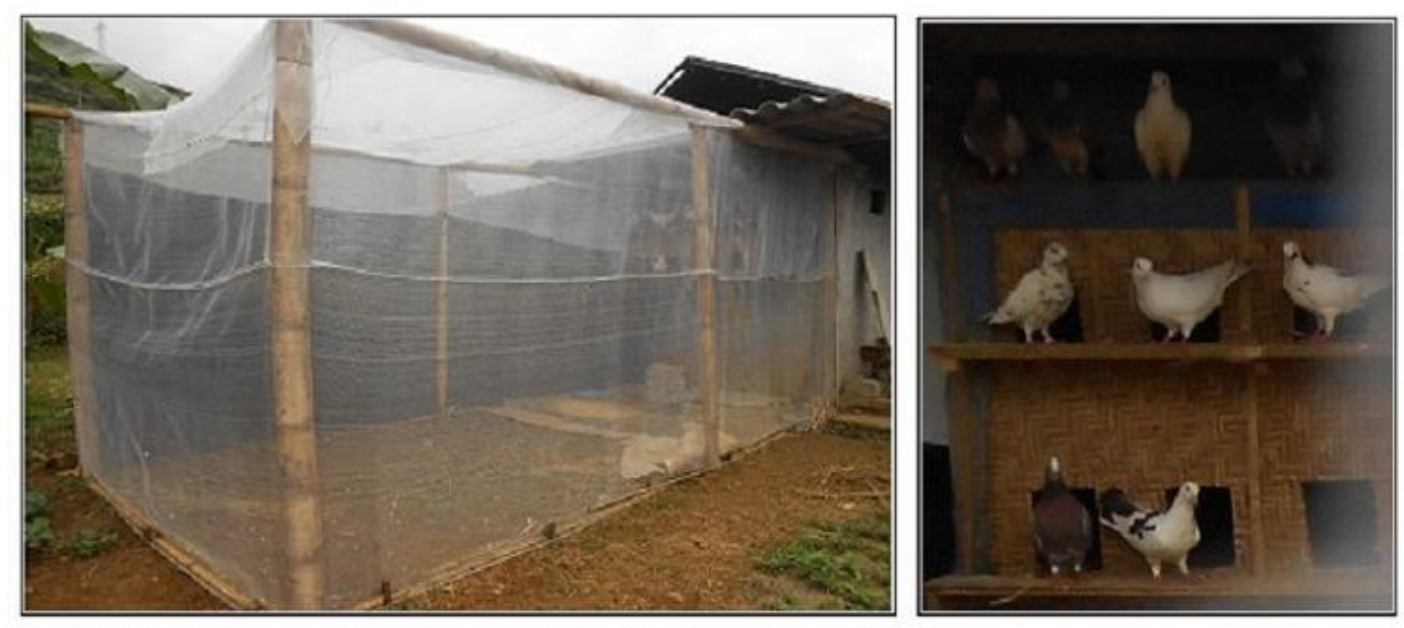

Model of raising dove in Ta Van commune in the buffer zone of the HLNP

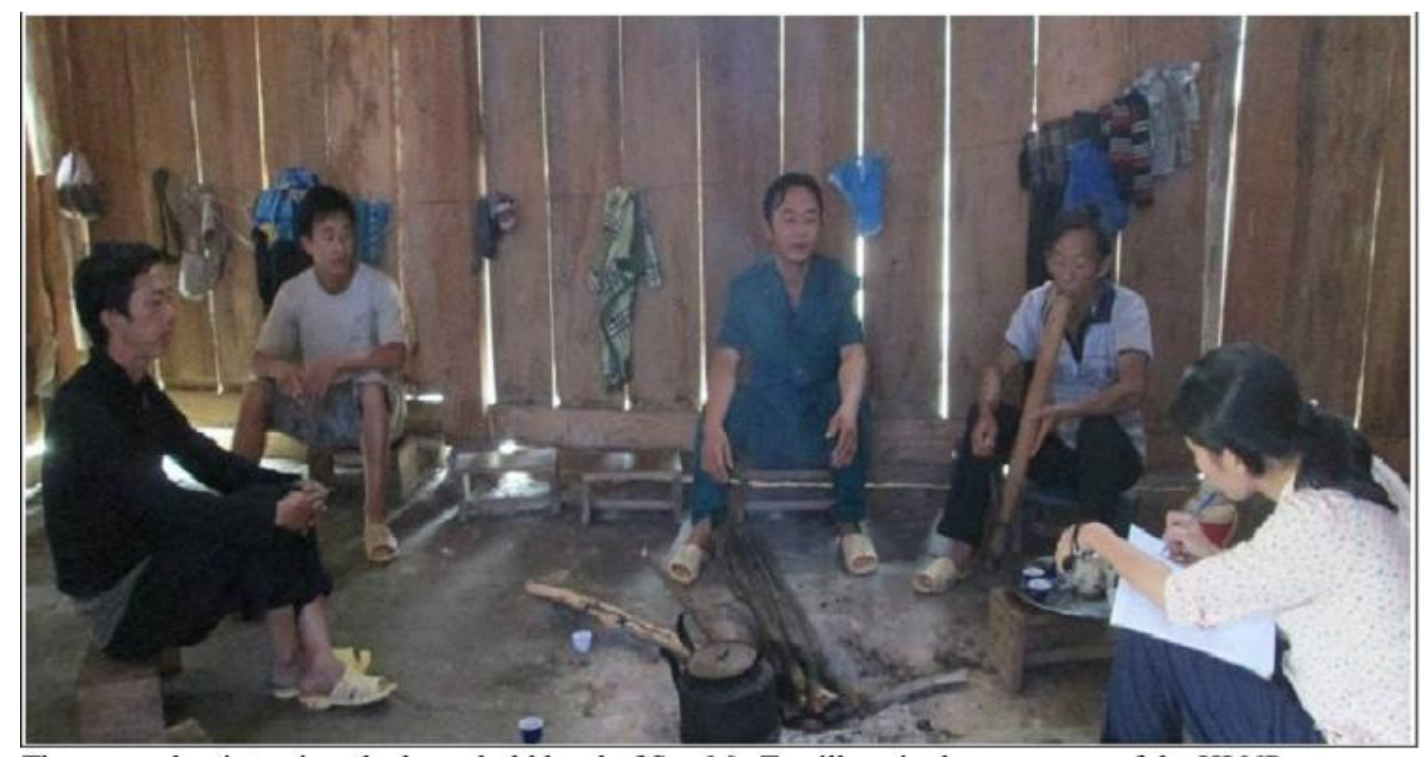

The researcher interview the household head of Seo My Ty village in the core zone of the HLNP 